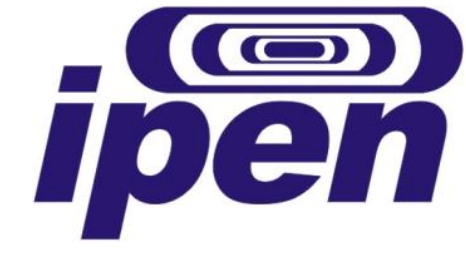

AUTARQUIA ASSOCIADA À UNIVERSIDADE DE SÃO PAULO

Hidrogéis poliméricos com nanopartículas de prata para aplicações médicas

Mara Tânia Silva Alcântara

Tese apresentada como parte dos requisitos para obtenção do Grau de Doutor em Ciências na Área de Tecnologia Nuclear - Materiais.

Orientador:

Prof. Dr. Humberto Gracher Riella 


\section{INSTITUTO DE PESQUISAS ENERGÉTICAS E NUCLEARES}

Autarquia associada à Universidade de São Paulo

Hidrogéis poliméricos com nanopartículas de prata para aplicações médicas

Mara Tânia Silva Alcântara

Tese apresentada como parte dos requisitos para obtenção do Grau de Doutor em Ciências na Área de Tecnologia Nuclear - Materiais.

Orientador:

Prof. Dr. Humberto Gracher Riella

Versão corrigida

Versão Original disponível no IPEN

São Paulo

2013 


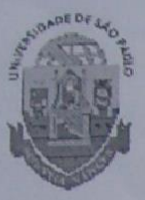

Universidade de São Paulo

Panus

RELATÓRIO DE DEFESA

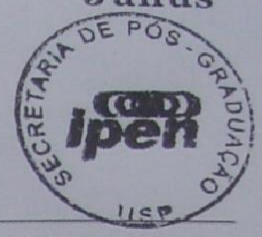

Aluno: 85134 - 5960265 - 2 / Página 1 de 1

Relatório de defesa pública de Tese do(a) Senhor(a) Mara Tania Silva Alcantara no Programa: Tecnologia Nuclear, Relatório de defesa pública de Tese do(a) Sencleares da Universidade de São Paulo.

do(a) Instituto de Pesquisas Energéticas e Nucleares da

Aos 03 dias do mês de abril de 2013, no(a) Auditório Rui Ribeiro Franco realizou-se a Defesa da Tón tótulo de Doutora intitulada:

Senhor(a) Mara Tania Silva Alcantara, apresentada para a obtenção do título de Doutora intitulada:

"Hidrogéis poliméricos com nanopartículas de prata para aplicações médicas"

(a) Sr(a) Presidente passa a palavra ao candidato para exposição e a seguir aos Após declarada aberta a sessão, o(a) Sr(a) Pre desenvolvem nos termos regimentais. Em seguida, a Comissão examinadores para as devidara proclama o resultado:

$\begin{array}{llll}\text { Nome dos Participantes da Banca } & \text { Função } & \text { Sigla da CPG } & \text { Resultado } \\ \text { Humberto Gracher Riella } & \text { Presidente } & \text { IPEN } & \text { Aprovado } \\ \text { Maria Elena Santos Taqueda } & \text { Titular } & \text { EP - USP } & \text { Aprovado } \\ \text { Nilton Erbet Lincopan Huenuman } & \text { Titular } & \text { ICB - USP } & \text { Aprovado } \\ \text { Antonio Jedson Caldeira Brant } & \text { Titular } & \text { CNEN/SP - Externo Aprovado } \\ \text { Nivaldo Cabral Kuhnen } & \text { Suplente } & \text { UFSC - Externo } & \text { Aprovado }\end{array}$

Resultado Final: Aprovado

\section{Parecer da Comissão Julgadora *}

Eu, Ana Claudia Martinelli Feher

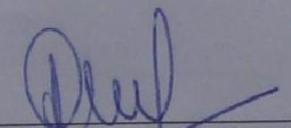
lavrei a presente ata, que assino juntamente com os(as) Senhores(as). São Paulo, aos 03 dias do mês de abril de 2013.

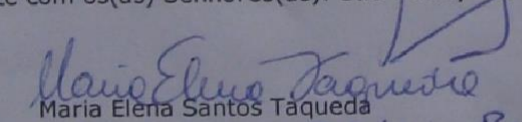
Maria Elena Santos Taqueda Antomio Jednon Cald

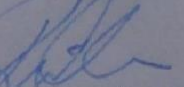

* Obs: Se o candidato for reprovado por algum dos membros, o preenchimento do parecer é obrigatório.

A defesa foi homologada pela Comissão de Pós-Graduação em $25, A B R, 2013$ _ portanto, o(a) aluno(a) faz jus ao título de Doutora em Ciências obtido no Programa Tecnologia Nuclear - Area de concentração: Tecnologia Nuclear Materiais.

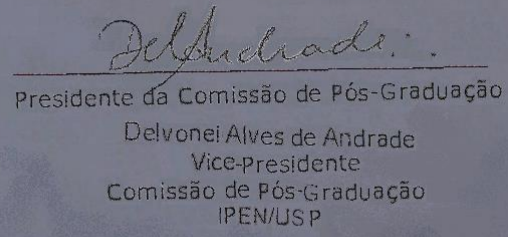




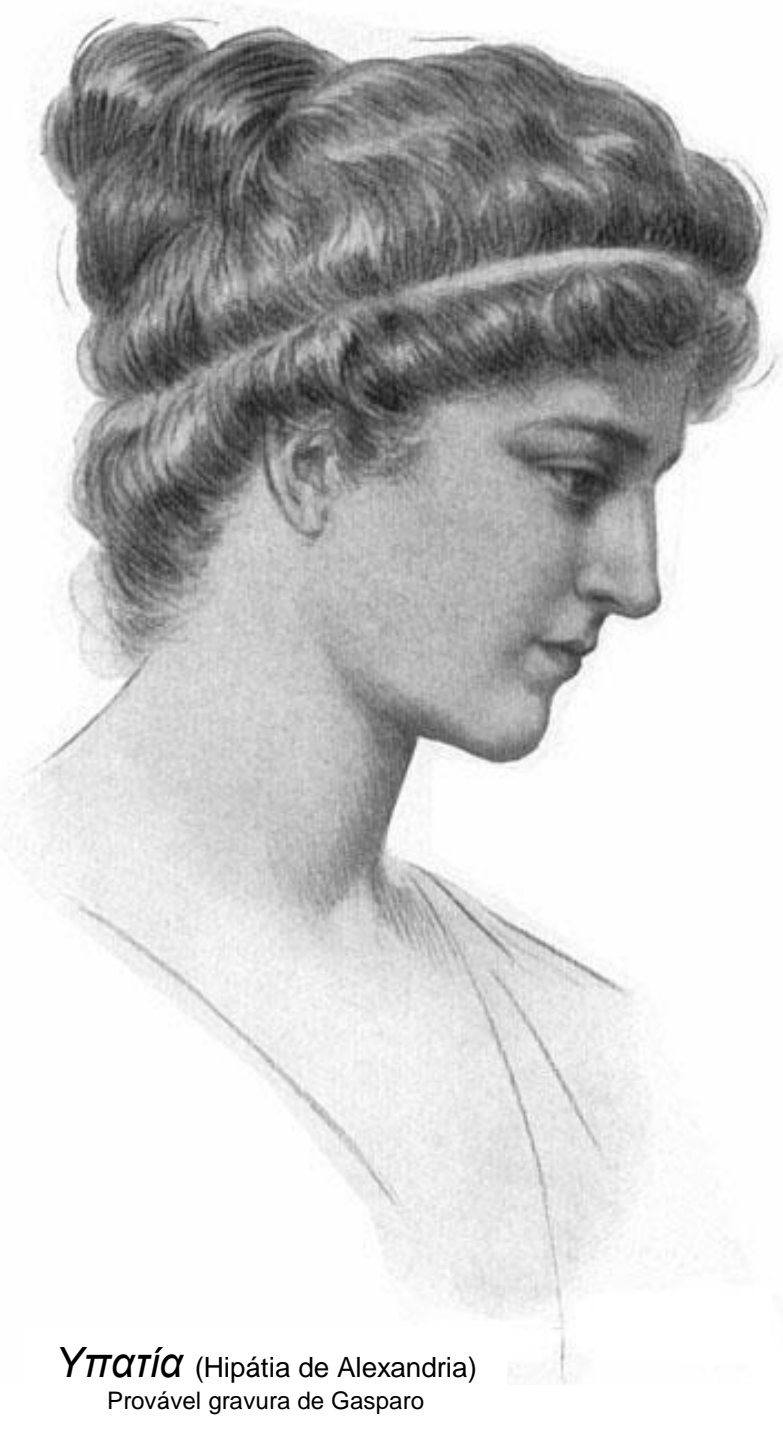

"Compreender as coisas que nos rodeiam é a melhor preparação para compreender $\sigma$ que há mais além".

Hipátia de Alexandria, por Elbert Hubbard

“... o estudo é importante. $\mathcal{O}$ saber é uma bênção. Mas não é um diploma que faz um homem, e sim, $\sigma$ valor que ele dá ao seu trabalho. $\mathcal{O}$ estudo prepara, mas o trabalho duro e honesto é que dignifica. Sim, estudar é uma benção. Mas ninguém é menos que outro porque não pôde estudar... E todos devem ser iguais no valor que dão ao que fazem: seja qual for a tarefa, deve ser feita com honestidade, com integridade, com alegria... $E$ com orgulho. Pois $\sigma$ trabalho, bem feito e honesto, é que faz $\sigma$ mundo andar e a vida dar certo... Assim como é $\sigma$ caráter, e não os títulos, e menos ainda a aparência, que faz a nossa caminhada no mundo valer a pena, pois nos torna uma pessoa de verdade". 


\section{DEDICATÓRIA}

- Dedico este trabatho, em especial, aos mens pais Jaime e Maria que me deram a vida e me ensinaram a vivê-la com dignidade, que iluminaram meus caminhos com amor, afeto e dedicação para que ew a trithasse sem medo e cheia de esperança, que se doaram inteiros e renunciaram aos sens sonhos para que, muitas vezes, eu pudesse realizar os mens. Mew eterno agradecimento pelo incondicional amor, carinho, paciência, apoio, incentivo, compreensão,...;

- A toda minha familia, que assim como mens pais, sempre foram a base da minha sustentação.

- À minha "madinha" Jovetina (ín memoriam) e ao meu "padim" Geraldo (in memoriam) minhas palavras de saudade pelo amor e carinho que me dedicaram, por terem sido os methores avós do mundo;

- À minha sobrinha Flavinha (ín memoriam), a mais doce e encantadora das crianças, mew muito obrigada pelo amor, carinho e alegrias que dew à minha vida.

- Ao men sobrinho Gabriel men agradecimento pela alegría de compartithar sua vida comigo.

- Á minha irmá Mara Jane e ao mew cunhado César, obrigada pelo carinho, apoio e ajuda em todos os momentos.

- A todos os Amigos que com seus exemplos fazem com que en me sinta cada dia mais fúrme na crença do valor do caráter, da ética, da dignidade, da sinceridade, da honestidade, do respeito, do amor, da humildade, da simplicidade, do profissionalismo e de todos os valores que dignificam o Homem. 


\section{AGRADECIMENTOS}

Nenhum trabalho é resultado apenas de um esforço individual, mas é o efeito de uma ação conjunta de pessoas que, direta ou indiretamente, contribuem para a sua realização. Desta forma, este trabalho é o resultado de um aprendizado iniciado na infância ao qual foram somando conhecimentos adquiridos no decorrer da vida. Portanto sou grata a cada um dos que passaram pela minha vida agregando valores e conhecimentos que resultaram não só neste trabalho como também na pessoa que sou.

- Agradeço, em primeiro lugar, a DEUS pelo dom da vida, por colocar no meu caminho pessoas que me cercaram de amor, carinho, cuidados e que tanto contribuíram para meu crescimento intelectual, profissional e moral, pela oportunidade de realizar este trabalho com dedicação e humildade, pela força que me impulsionou a chegar até aqui e por me orientar a todo o momento, pois sem ele nada seria possível.

- Ao meu orientador, Prof. Dr. Humberto Gracher Riella, pelo apoio no desenvolvimento deste projeto e importância na realização deste trabalho.

- Ao meu coorientador, Prof. Dr. Ademar Benévolo Lugão, por ter me acolhido no seu grupo de polímeros, por compartilhar uma parte de seus conhecimentos comigo, pela oportunidade, confiança e apoio para iniciar este trabalho.

- À Prof. Dra. Maria Elena dos Santos Taqueda meu agradecimento e sincera gratidão pela orientação e inestimável contribuição na realização do planejamento experimental e interpretação dos resultados, assim como pelo carinho, atenção e preocupação.

- Ao Prof. Dr. Antônio Jedson Caldeira Brant, pelo apoio, incentivo, sugestões, preciosas discussões e pronta disponibilidade para o esclarecimento de dúvidas, assim como pelo carinho, atenção e respeito.

- Ao Prof. Dr. Nilton Erbet Lincopan Huenuman, Bel. Priscila Martins dos Santos e Dra. Priscilia Aguilar Ramirez do Instituto de Ciências Biológicas - USP, obrigada pelo apoio, atenção e disposição em ajudar através da realização dos ensaios bacteriológicos e de citotoxicidade.

- À Danielle Giannini e Jovelina Pessoa, obrigada pelo enorme carinho, dedicação e incansável auxílio na preparação e caracterização de grande parte das amostras, pois sem suas valiosas contribuições, transpiração e dedicação não teria sido possível a realização deste trabalho.

- Ao Prof. Dr. Luis Felipi C. P. Lima, muito obrigada pelo carinho, incentivo, apoio, atenção, discussões, pelo exemplo profissional e pela oportunidade de convivência e aprendizado.

- À Prof. Dra. Olga Higa agradeço pela ajuda na liofilização de parte das amostras e principalmente pelo carinho, atenção e incentivo. 
- Ao Dr. Jorge Vaz e Dra. Nilce meus agradecimentos pela disponibilização do espectrofotômetro para as análises de UV-visível, assim como pela ajuda e atenção despendida.

- À Msc. Sizue e ao Prof. Dr. Rogero agradeço pelo uso da balança semianalítica, bomba de vácuo, dissecador e purificador de água de osmose reversa, assim como das embalagens circulares para preparação de corpos de prova e à Dra. Cláudia agradeço pela atenção e disponibilização do liofilizador.

- Ao João e Takeschi obrigada pela atenção, pelos quebra-galhos e adaptações, sem os quais alguns experimentos teriam sido inviáveis.

- Aos queridos Amigos Andréia, Brant, Hellen, Maria José, Renata, Sandra, Sousa, e Washington obrigada pelas inúmeras contribuições como também pela amizade, carinho, companheirismo, apoio, incentivo e palavras de conforto, principalmente nos momentos mais difíceis. A participação de vocês foi fundamental nessa minha caminhada.

- Aos queridos amigos Adriana, Adrianinha, Ana Carolina, Beth, Carolina, Duclerc, Eleosmar, Gislaine, Harumi, Heloisa, Henrique, Kiriaki, Laura, Nádia, Natália, Nelson, Patrícia, Pedro, Pereira, Ricardinho, Roberta e Sirlene, obrigada pela amizade, carinho, convívio, apoio e incentivo.

- A TODOS os alunos de iniciação científica do grupo de polímeros, em especial aos que passaram pelo laboratório de biomateriais poliméricos, desde que cheguei, obrigada pelo carinho, confiança e colaboração.

- A todo o pessoal da secretaria do CQMA, obrigada pela atenção e constante apoio.

- A todos os professores do IPEN, obrigada pelo carinho, atenção, amizade e aprendizado, em especial ao Prof. Dr. Arnaldo H. Paes de Andrade, principalmente no Programa de Aperfeiçoamento de Ensino.

- A todos os professores da USP, em especial ao Prof. Dr. Hélio Wiebeck, obrigada pela amizade, carinho e conhecimentos que agregaram.

- Meus agradecimentos aos inúmeros amigos que aqui fiz, a todos os mestrandos, doutorandos e profissionais que colaboraram direta ou indiretamente para a realização deste trabalho.

- Muito obrigada à CNEN/IPEN pela oportunidade e apoio oferecido, em especial ao Centro de Química e Meio Ambiente (CQMA) onde este trabalho foi desenvolvido; ao Centro de Tecnologia das Radiações (CTR), em especial à Elizabeth S. R. Somessari, Carlos G. da Silveira e Pablo Antonio Vásquez Salvador pelo carinho, atenção e irradiação das amostras; ao Centro de Ciência e Tecnologia dos Materiais (CCTM), em especial à Flávia, Cebolinha e Glauson pela atenção e análises microscópica e ao pessoal do departamento de informática pela atenção e suporte. Obrigada a todos pela disposição em ajudar, pelo carinho, atenção e amizade. 
- Agradeço à Universidade de São Paulo, à comissão de pós-graduação do IPEN, a todos os seus colaboradores que apoiaram a realização deste trabalho, em especial à Gislene Madeira, Ana Cláudia e Ana Maria Maiorino, pela atenção, apoio e suporte.

- À Stat Ease agradeço pela disponibilização do software Design-Expert 8 45-Day Trial, que permitiu o planejamento estatístico e a análise dos dados aqui apresentados.

- À CAPES - Coordenação de aperfeiçoamento de pessoal de nível superior, agradeço pela bolsa de doutorado concedida através do Programa de Apoio ao Ensino e à Pesquisa Científica e Tecnológica em Engenharia - Pró-Engenharias.

- A TODOS os meus professores que me ensinaram e ajudaram a trilhar o caminho do conhecimento, em especial às minhas primeiras professoras, D. Rose e D. Ana Maria Tavares Ponce que me alfabetizaram e ensinaram a dar meus primeiros passos e ao Msc. Roberto Teixeira Pessini pelos mais importantes ensinamentos.

- Às Queridas Amigas de todas as horas Elaine, Ivete, Magali, Marines e Mirna que souberam entender a minha ausência nos muitos momentos dedicado a este trabalho, obrigada pelo carinho, apoio, incentivo, preocupação e paciência.

- Aos Queridos Amigos que entraram na minha vida por uma "Razão" ou uma "Estação" obrigada pelo apoio, incentivo, carinho e ensinamentos:

- Às amigas Ana, Carolina, Deise, Elaine, Ivete e Marines com quem aprendi a importância do trabalho em equipe, da amizade sincera e confiança. Obrigada pelo companheirismo, carinho e compreensão.

- Aos amigos Dr. Amado, Dra. Eloisa, Eliane, Ivone, Mauro e Umberto. Obrigada pela amizade, carinho, atenção e apoio.

- Aos amigos Antoska, Hélio, Magali, Marcel e Ulisses obrigada pelo carinho, ajuda, apoio, incentivo, compreensão, companheirismo e tudo que compartilhamos juntos.

- Aos amigos Bovi (in memoriam), Carlos, Carlos Motta, Célia, Dalto, Diniz, Jandir, Janin, Luiz, Marilda, Paulinho, e em especial ao Requena que me segurou pela mão quando comecei a dar meus primeiros passos na minha carreira profissional, assim como ao Milton Barreto que ainda continuou abrindo muitas portas, sempre com muito carinho, respeito, atenção, preocupação e exemplo de liderança, ética, dignidade e profissionalismo. Obrigada por todo o carinho, aprendizagem e marcas que deixaram.

- Aos amigos Acyr e Mirna, meus agradecimentos pela amizade, carinho, apoio e constante motivação.

- Aos amigos Eugênio e Mauro, obrigada pelo carinho, amizade e apoio. 
- Aos amigos Carlini, Serginho e Zeca meu agradecimento pelo apoio, carinho e amizade.

- Aos amigos Antônio Luiz, Eduardo e Mário, obrigada pela amizade, carinho, atenção e exemplo de profissionalismo, respeito, ética e dignidade.

Enfim, OBRIGADA A TODOS os familiares e amigos que sempre acreditaram no sucesso desta empreitada, que direta ou indiretamente contribuíram para a realização deste trabalho e para o meu aprendizado intelectual e espiritual, que estiveram ao meu lado dando força e apoio, trazendo alegria e ajudando a trilhar meu caminho. Vocês foram os presentes que recebi de Deus, aqueles que não compramos, pois não há preço nem dinheiro nenhum no mundo para pagar. São presentes que colhemos da árvore da vida, são frutos da amizade e do amor. Que Deus abençoe e ilumine cada um de vocês. 
"Quando nada parece dar certo, vou ver o cortador de pedras martelando sua rocha talvez 100 vezes, sem que uma única rachadura apareça. Mas na centésima primeira martelada a pedra se abre em duas, e eu sei que não foi aquela que conseguiv isso, mas todas as que vieram antes".

JacofRiss (1849-1914)

"Não se mede $\sigma$ valor de um homem pelas suas roupas ou pelos bens que possui, o verdadeiro valor do homem é $\sigma$ sen caráter, suas ideias e a nobreza dos sens ideais".

Charles Chaplin

"O SENHOR é o meu pastor e nada me faltará. Deita-me em verdes pastos e guia-me mansamente em águas tranquilas. Refrigera a minha alma e guia-me pelas veredas da justiça, por amor do sew nome". 


\title{
HIDROGÉIS POLIMÉRICOS COM NANOPARTÍCULAS DE PRATA PARA APLICAÇÕES MÉDICAS
}

\author{
Mara Tânia Silva Alcântara
}

\section{RESUMO}

O desenvolvimento de novos procedimentos e tecnologias tem proporcionado um grande avanço no tratamento de feridas e queimaduras, melhorando a qualidade de vida das vítimas e reduzindo as taxas de mortalidade de pessoas com queimaduras graves. Entretanto as complicações infecciosas continuam sendo um desafio e uma das principais causas de óbito de queimados. Por outro lado, em todo o mundo tem-se observado um crescente interesse no uso de hidrogéis para aplicação como curativos para queimaduras, ferimentos e úlceras de pele, tendo em vista que são capazes de absorver exsudatos, ajudam na cicatrização e proporcionam conforto ao paciente, uma vez que favorecem o alívio da dor. Além disso, os hidrogéis também podem ser aplicados como matrizes para sistemas de liberação controlada de princípios ativos e agentes antimicrobianos. O objetivo deste trabalho foi estudar as propriedades mecânicas e físico-químicas de hidrogéis compostos por blendas formadas por Poli $(N$-vinil-2pirrolidona)/ Polietilenoglicol/ ágar (PVP/PEG/ágar), Poli( $N$-vinil-2-pirrolidona)/ glicerol/ ágar (PVP/glicerol/ágar); Poli(álcool vinílico)/ kappa-carragena/ ágar (PVA/KC/ágar), reticuladas por radiação ionizante. Para a preparação das blendas, utilizou-se planejamento de misturas como ferramenta, oferecendo assim subsídios a futuros desenvolvimentos de novos hidrogéis, que possam ser usados como curativos e como matrizes poliméricas para liberação de ativos hidrofílicos e lipofílicos. Foram otimizadas três formulações e sintetizadas seis, três das quais hidrogéis nanocompósitos de prata. As nanopartículas de prata (NPAg) foram sintetizadas, in situ, por radiação gama, sem uso de catalisadores ou outro reagente para obtenção de curativo mais puro e com ação antimicrobiana. A caracterização físico-química dos hidrogéis foi obtida por análises de fração gel, intumescimento, ensaios de tração e perfuração, microscopia eletrônica de varredura (MEV), espectroscopia na região do ultravioleta-visível (UV-vis). Também foi avaliada a atividade antimicrobiana dos hidrogéis e realizado estudo de citotoxicidade in vitro. O planejamento de misturas apresentou modelos confiáveis para os resultados de fração gel e intumescimento, porém, para as propriedades mecânicas, os resultados devem ser vistos com cautela. $O$ uso da radiação se mostrou eficaz para a síntese de NPAg in situ nas blendas estudadas. Os resultados sugerem que os hidrogéis sintetizados não liberaram NPAg, porém os hidrogéis de PVP apresentaram atividade bactericida para $S$. aureus e $P$. Aeruginosa, enquanto que o hidrogel de PVA apresentou atividade bactericida para $P$. aeruginosa e atividade bacteriostática para $S$. aureus, sendo essa atividade pelo contato direto. 


\title{
POLYMERIC HYDROGELS WITH SILVER NANOPARTICLES FOR MEDICAL APPLICATIONS
}

\author{
Mara Tânia Silva Alcântara
}

\begin{abstract}
The development of new procedures and technologies have provided a major advance in the treatment of wounds and burns improving the quality of life of victims and reducing mortality rates of people with severe burns. However, infectious complications remain a challenge and a major cause death to burn. Furthermore, in the whole world, an increasing interest in the use of hydrogels as dressings for burns, wounds and skin ulcers has been observed, considering that they are capable of absorbing exudates, aid in healing and provide confort to the patient, since they favor the pain relief. In addition, hydrogels can also be applied as matrices for controlled release systems of active and antimicrobial agents. The aim of this study was to investigate the mechanical and physicochemical properties of hydrogels composed of blends formed by poly( $\mathrm{N}$-vinyl-2-pyrrolidone)/ Polyethylene glycol/ agar (PVP/PEG/agar), poly(N-vinyl-2-pyrrolidone)/ glycerol/agar (PVP/ glycerol/agar) and poly(vinyl alcohol)/ kappa-carrageenan/ agar (PVA/KC/agar), crosslinked by ionizing radiation. In blends' preparation, design of mixtures was utilized as a tool, thus offering information for future developments of new hydrogels, which can be used as dressings and as polymer matrices for the release of lipophilic and hydrophilic actives. Three formulations were optimized, and six synthesized, being three of these silver nanocomposite hydrogels. The silver nanoparticles (AgNPs) were synthesized, in situ, by gamma irradiation without using a catalyst or other reagent in order to obtain wound dressing with higher purity and antimicrobial activity. The physicochemical characterization of the hydrogels was obtained using assays of gel fraction, swelling, tensile and perforation, scanning electron microscopy (SEM), spectroscopy in the ultraviolet-visible (UV-vis) region. Antimicrobial activity of the hydrogels was evaluated, and cytotoxicity study in vitro also was performed. The mixture design offered reliable models for gel fraction and swelling, but for the mechanical properties the results must be seen with caution. The use of radiation has proven to be effective for synthesis of AgNPs in situ in the blends studied. The results suggest that hydrogels synthesized did not release AgNPs, but the PVP hydrogels showed bactericidal activity for $S$. aureus and $P$. aeruginosa, whereas the PVA hydrogel had bactericidal activity for $P$. Aeruginosa and bacteriostatic activity for $S$. aureus, being this activity by direct contact.
\end{abstract}




\section{SUMÁRIO}

\section{RESUMO}

\section{ABSTRACT}

\section{SUMÁRIO}

Lista de tabelas

Lista de figuras

Lista de abreviaturas e siglas

Lista de símbolos

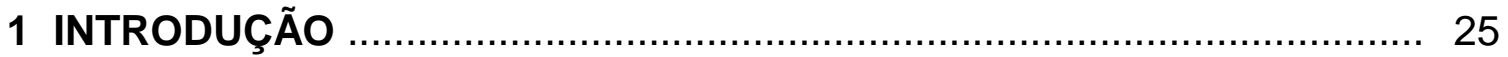

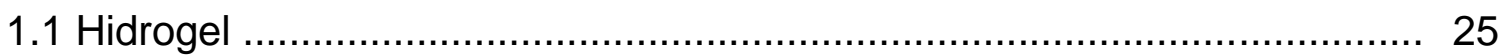

1.2 Aplicações biomédicas dos hidrogéis ............................................... 25

1.2.1 Sistema de liberação controlada de drogas ..................................... 26

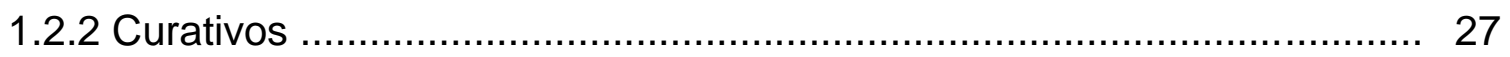

1.3 Curativos de hidrogel reticulados por radiação ................................... 32

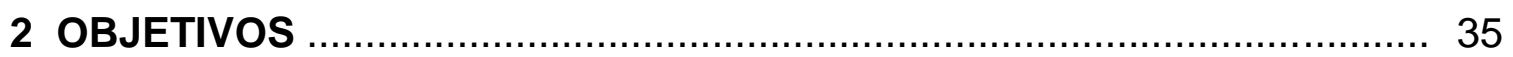

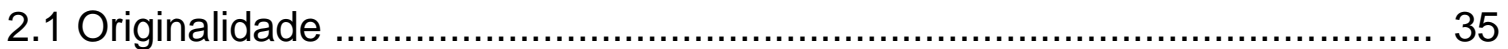

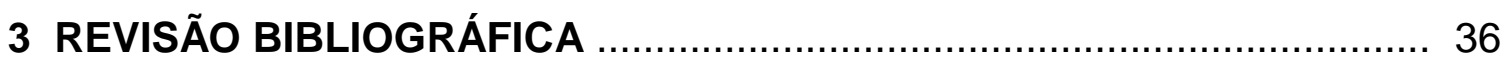

3.1 Biomateriais poliméricos ............................................................... 36

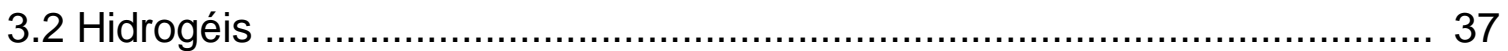

3.2.1 Classificação dos hidrogéis ................................................... 37

3.2.2 Estrutura dos hidrogéis .......................................................... 38

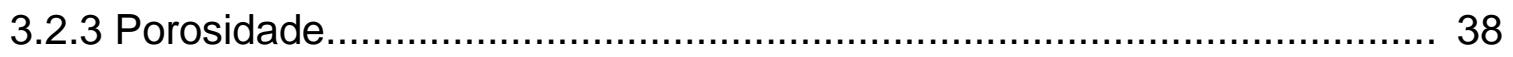

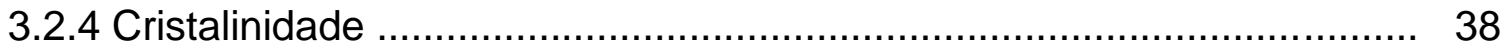

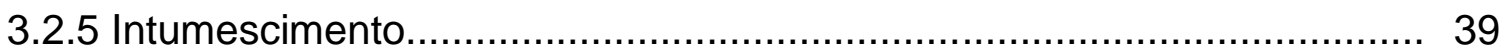

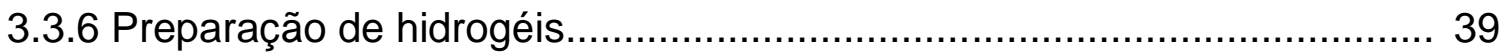

3.3 Radiação ionizante ................................................................... 40

3.3.1 Interação da radiação de alta energia com os polímeros....................... 41

3.3.2 Radiólise da água .................................................................... 42

3.3.3 Efeito da radiação em sistemas aquosos ......................................... 43

3.3.4 Efeito da radiação no PVP, PVA, PEG, glicerol, ágar e KC................... 44 
3.3.5 Esterilização por raios gama ...................................................... 47

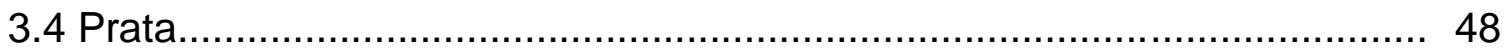

3.4.1 Propriedades das NPAg...................................................... 48

3.4.2 Síntese de NPAg por raios gama .............................................. 49

3.4.3 Ação biocida das NPAg e sua toxicidade em seres humanos ............... 51

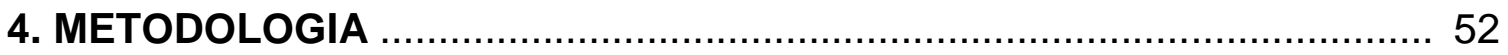

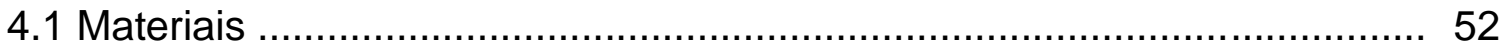

4.2 Planejamento de misturas ......................................................... 52

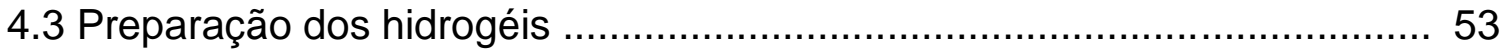

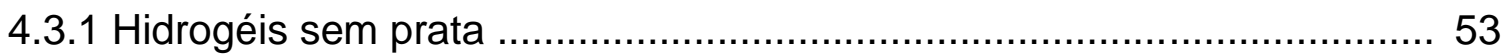

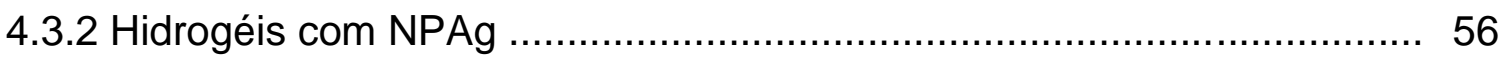

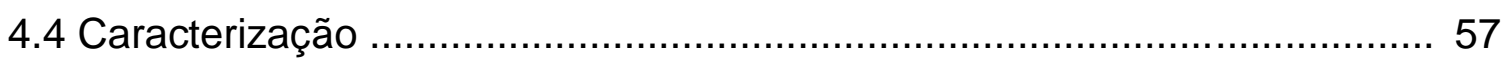

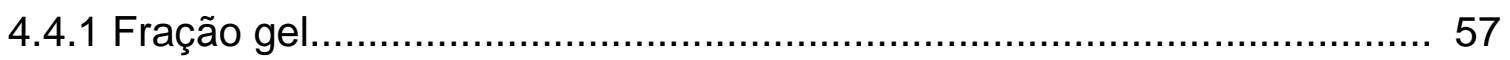

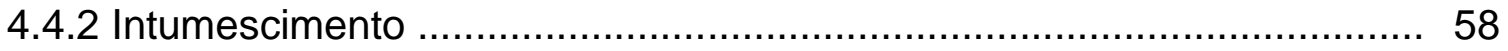

4.4.3 Propriedades mecânicas........................................................... 59

4.4.3.1 Ensaio de tração: tensão, deformação e módulo elástico .................. 59

4.4.3.2 Ensaios de perfuração: Força puntiforme e deformação....................... 60

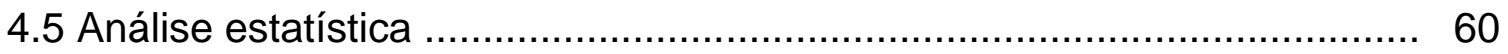

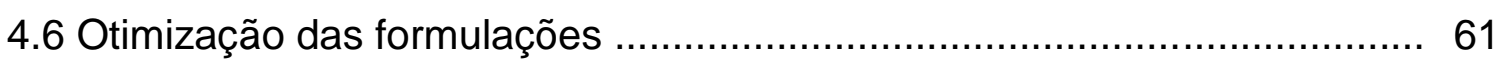

4.7 Espectroscopia na região do ultravioleta-visível .................................. 61

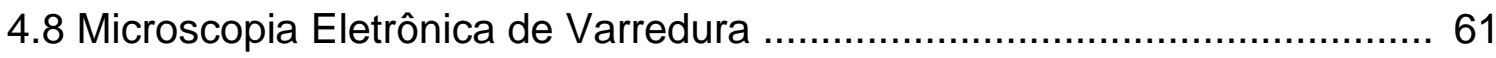

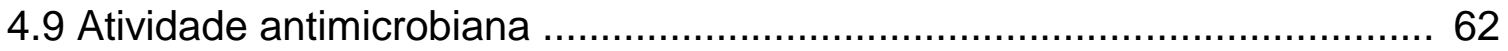

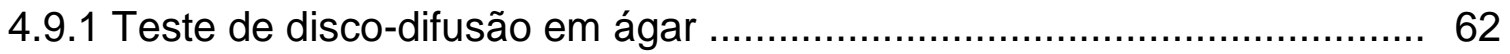

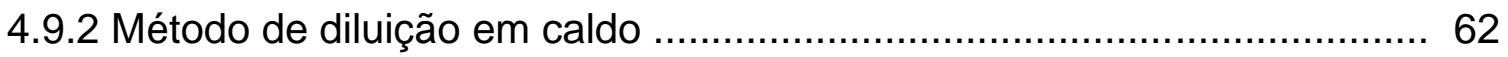

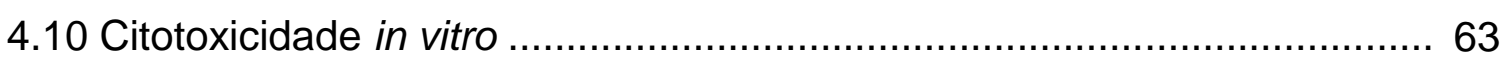

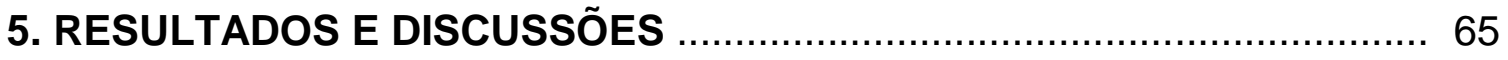

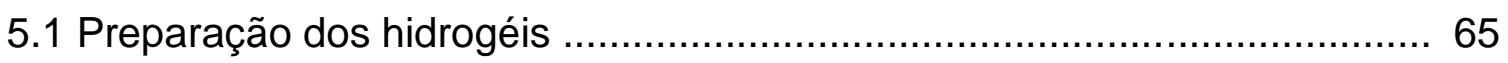

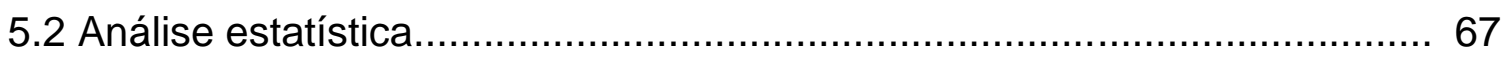

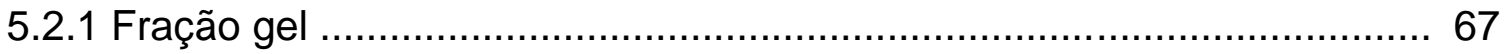

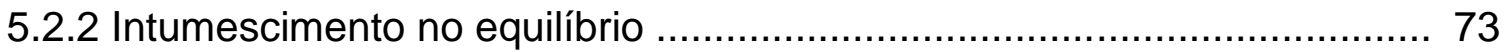

5.2.3 Propriedades mecânicas .......................................................... 81

5.2.3.1 Resistência à tração ...................................................................... 83 


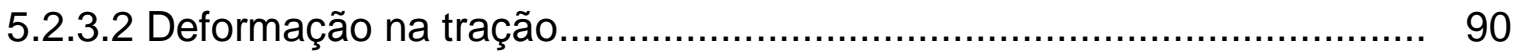

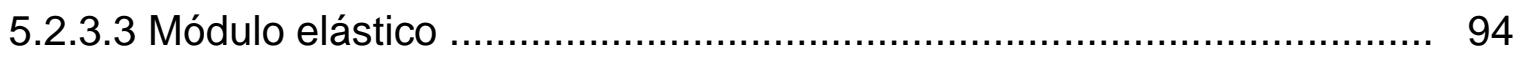

5.2.3.4 Resistência à perfuração ............................................................ 99

5.2.3.5 Deformação na perfuração ......................................................... 105

5.3 Otimização ............................................................................... 110

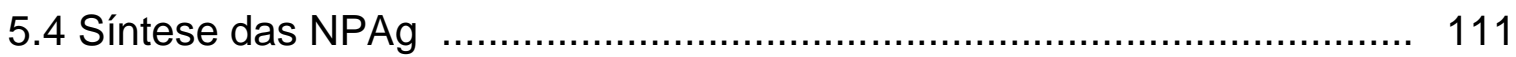

5.5. Caracterização: Fórmulas otimizadas e com NPAg ............................ 113

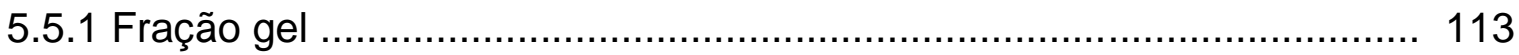

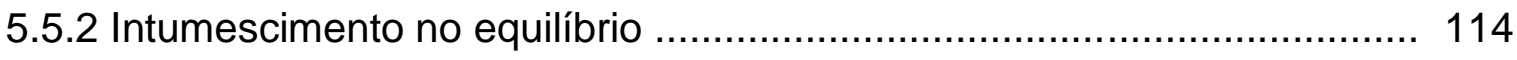

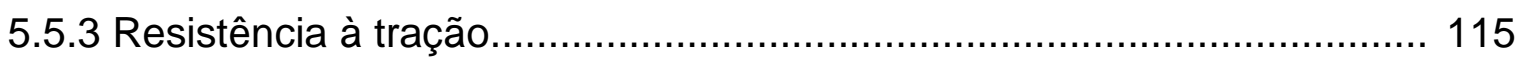

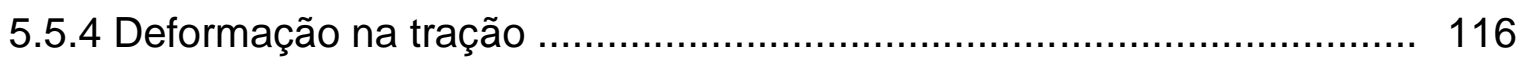

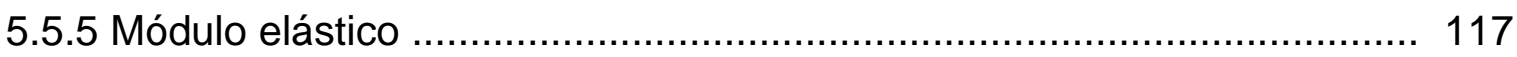

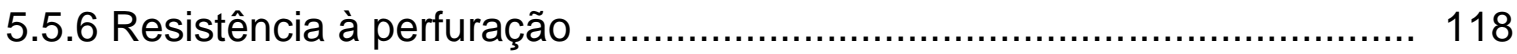

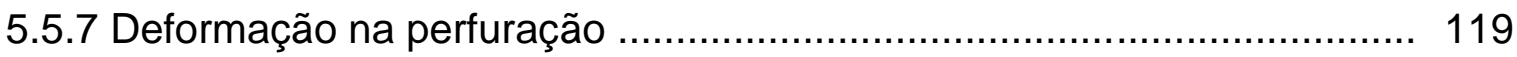

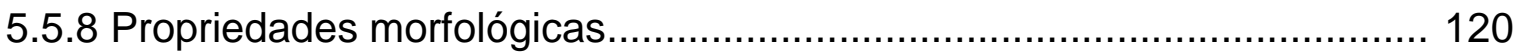

5.5.9 Distribuição das NPAg ........................................................... 122

5.5.10 Atividade antimicrobiana dos hidrogéis com NPAg .......................... 124

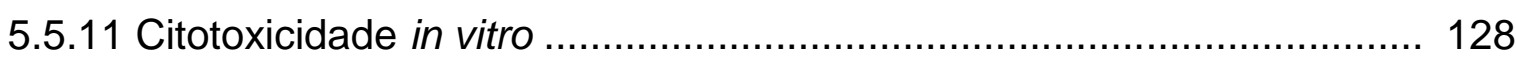

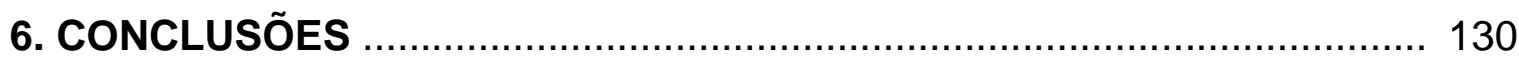

Sugestões de trabalhos futuros ............................................................. 132

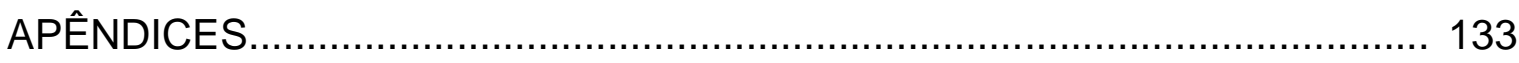

.APÊNDICE A - Análise estatística - Fração gel ........................................... 133

APÊNDICE B - Análise estatística - Intumescimento no equilíbrio ................ 136

APÊNDICE C - Análise estatística - Resistência à tração .............................. 139

APÊNDICE D - Análise estatística - Deformação na tração .......................... 142

APÊNDICE E - Análise estatística - Módulo elástico …................................. 145

APÊNDICE F - Análise estatística - Resistência à perfuração ........................ 148

APÊNDICE G - Análise estatística - Deformação na perfuração ...................... 151

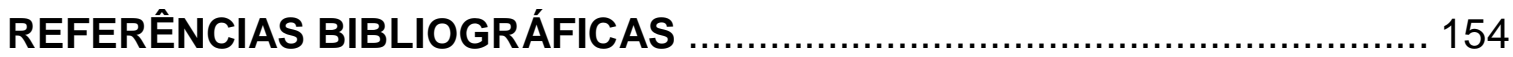




\section{Lista de tabelas}

Tabela 4.1 Limites dos componentes das misturas para síntese de hidrogéis

Tabela 4.2 Composições sugeridas pelo software Design-Expert円 para preparação das misturas para síntese dos hidrogéis.

Tabela 5.1 Composição final, após ajuste, dos hidrogéis preparados e irradiados.

Tabela 5.2 Composição dos hidrogéis otimizados.

Tabela A 1.1 ANOVA da regressão para o modelo quadrático da regressão de fração gel para o sistema PVP/PEG/ágar.

Tabela A 1.2 Coeficientes reais e pseudos estimados para a regressão de fração gel para o sistema PVP/PEG/ágar

Tabela A 2.1 ANOVA da regressão para o modelo quadrático da regressão de fração gel para o sistema PVP/glicerol/ágar.

Tabela A 2.2 Coeficientes reais e pseudos estimados para a regressão de fração gel para o sistema PVP/glicerol /ágar.

Tabela A 3.1 ANOVA da regressão para o modelo linear da regressão de fração gel para o sistema PVA/KC/ágar.

Tabela A 3.2 Coeficientes reais e pseudos estimados para a regressão de fração gel para o sistema PVA/KC/ágar.

Tabela B 1.1 ANOVA da regressão para o modelo quadrático da regressão de intumescimento para o sistema PVP/PEG/ágar.

Tabela B 1.2 Coeficientes reais e pseudos estimados para a regressão de intumescimento para o sistema PVP/PEG/ágar.

Tabela B 2.1 ANOVA da regressão para o modelo quadrático da regressão de intumescimento para o sistema PVP/glicerol/ágar

Tabela B 2.2 Coeficientes reais e pseudos estimados para a regressão de intumescimento para o sistema PVP/glicerol/ágar.

Tabela B 3.1 ANOVA da regressão para o modelo quadrático da regressão de intumescimento para o sistema PVA/KC/ágar. 
Tabela B 3.2 Coeficientes reais e pseudos estimados para a regressão de intumescimento para o sistema PVA/KC/ágar..

Tabela C 1.1 ANOVA da regressão para o modelo quadrático da regressão de resistência à tensão para o sistema PVP/PEG/ágar

Tabela C 1.2 Coeficientes reais e pseudos estimados para a regressão de tensão para o sistema PVP/PEG/ágar.

Tabela C 2.1 ANOVA da regressão para o modelo quadrático da regressão de tensão para o sistema PVP/glicerol/ágar.

Tabela C 2.2 Coeficientes reais e pseudos estimados para a regressão de tensão para o sistema PVP/glicerol/ágar.

Tabela C 3.1 ANOVA da regressão para o modelo quadrático da regressão de tensão para o sistema PVA/KC/ágar.

Tabela C 3.2 Coeficientes reais e pseudos estimados para a regressão de tensão para o sistema PVA/KC/ágar.

Tabela D 1.1 ANOVA da regressão para o modelo quadrático da regressão de deformação na tração para o sistema PVP/PEG/ágar.

Tabela D 1.2 Coeficientes reais e pseudos estimados para a regressão de deformação na tração para o sistema PVP/PEG/ágar.

Tabela D 2.1 ANOVA da regressão para o modelo linear da regressão de deformação na tração para o sistema PVP/glicerol/ágar......

Tabela D 2.2 Coeficientes reais e pseudos estimados para a regressão de deformação na tração para o sistema PVP/glicerol/ágar.

Tabela D 3.1 D3.1 - ANOVA da regressão para o modelo quadrático da regressão de deformação na tração para o sistema PVA/KC/ágar.

Tabela D 3.2 Coeficientes reais e pseudos estimados para a regressão de deformação na tração para o sistema PVA/KC/ágar.

Tabela E 1.1 ANOVA da regressão para o modelo quadrático da regressão de módulo elástico para o sistema PVP/PEG/ágar.

Tabela E 1.2 Coeficientes reais e pseudos estimados para a regressão de módulo elástico para o sistema PVP/PEG/ágar.

Tabela E 2.1 ANOVA da regressão para o modelo quadrático da regressão de módulo elástico para o sistema PVP/glicerol/ágar.

Tabela E 2.2 Coeficientes reais e pseudos estimados para a regressão de módulo elástico para o sistema PVP/glicerol/ágar.

Tabela E 3.1 ANOVA da regressão para o modelo quadrático da regressão de módulo elástico para o sistema PVA/KC/ágar.

Tabela E 3.2 Coeficientes reais e pseudos estimados para a regressão de módulo elástico para o sistema PVA/KC/ágar. 
Tabela F 1.1 ANOVA da regressão para o modelo linear da regressão de força puntiforme para o sistema PVP/PEG/ágar

Tabela F 1.2 Coeficientes reais e pseudos estimados para a regressão de força puntiforme para o sistema PVP/PEG/ágar.

Tabela F 2.1 ANOVA da regressão para o modelo quadrático da regressão de força puntiforme para o sistema PVP/glicerol/ágar.

Tabela F 2.2 Coeficientes reais e pseudos estimados para a regressão de força puntiforme para o sistema PVP/glicerol/ágar

Tabela F 3.1 ANOVA da regressão para o modelo linear da regressão de força puntiforme para o sistema PVA/KC/ágar.

Tabela F 3.2 Coeficientes reais e pseudos estimados para a regressão de força puntiforme para o sistema PVA/KC/ágar

Tabela G 1.1 ANOVA da regressão para o modelo quadrático da regressão de deformação na perfuração para 0 sistema PVP/PEG/ágar

Tabela G 1.2 Coeficientes reais e pseudos estimados para a regressão de deformação na perfuração para o sistema PVP/PEG/ágar.

Tabela G 2.1 ANOVA da regressão para o modelo quadrático da regressão de deformação na perfuração para 0 sistema $\mathrm{PVP} /$ glicerol/ágar.

Tabela G 2.2 Coeficientes reais e pseudos estimados para a regressão de deformação na perfuração para 0 sistema $\mathrm{PVP} /$ glicerol/ágar.

Tabela G 3.1 ANOVA da regressão para o modelo cúbico especial da regressão de deformação na perfuração para o sistema PVA/KC/ágar.

Tabela G 3.2 Coeficientes reais e pseudos estimados para a regressão de deformação na perfuração para o sistema PVA/KC/ágar. 


\section{Lista de figuras}

Figura 1.1 Imagens ilustrativas de hidrogéis utilizados como sistema de liberação de princípios ativos.................................................. 27

Figura 1.2 Imagens ilustrativas de lesões com curativos de hidrogel.......... 28

Figura 1.3 Imagens ilustrativas de diferentes graus de queimadura recobertas com curativo.................................................... 30

Figura 1.4 Imagens ilustrativas de lesões infectadas; queimadura e ferida....................................................................... 31

Figura 3.1 Classificação dos hidrogéis................................................. 37

Figura 3.2 Interação dos fótons de alta energia com matéria orgânica.... 41

Figura 3.3 Produtos mais importantes formados pela radiólise da água no estado líquido............................................................... 42

Figura 3.4 Mecanismo genérico de radiólise para solutos orgânicos em solução aquosa......

Figura 3.5 Estrutura dos macrorradicais formados como resultado da abstração do hidrogênio do PVP pelos radicais hidroxila.

Figura 3.6 Estrutura dos macrorradicais formados como resultado da abstração do hidrogênio do PVA, pelos radicais hidroxila.......

Figura 3.7 Estrutura dos macrorradicais formados aleatoriamente, após irradiação de PEG, sob determinadas condições.

Figura 3.8 Estrutura molecular do propano-1,2,3-triol.............................. 46

Figura 3.9 Reação de captura de radical $\mathrm{OH}^{*}$ pelo metanol........................ 46

Figura 3.10 Estrutura da agarose e k-carragena........................................ 47

Figura 3.11 Modelos de transição conformacional da k-carragena............... 47

Figura 3.12 Relação entre o tamanho e o comprimento de onda do pico espectral das NPAg e suas formas geométricas.

Figura 3.13 Reação de redução do íon prata, pela ação da radiólise da água.

Figura 3.14 Mecanismo de formação de cluster de prata.

Figura 3.15 Mecanismo da ligação de coordenação entre o PVP e as NPAg...... 
Figura 4.1 Preparação dos hidrogéis................................................... 55

Figura 4.2 Irradiador de Cobalto-60 do tipo gammacell 220....................... 56

Figura 4.3 Amostras de hidrogéis antes do intumescimento, após estabilização do peso e desintegrada ou colapsada.................. 58

Figura 4.4 Diagrama de Sobral et al. (2001), modificado.......................... 60

Figura 4.5 Amostras de hidrogéis com e sem prata, com P. aeruginosa, e amostras mergulhadas no meio nutritivo

Figura 5.1 Resultados de fração gel obtidos e previstos na análise dos hidrogéis sintetizados, para os sistemas PVP/PEG/ágar e PVP/glicerol/ágar.

Figura 5.2 Diagrama com as linhas de contorno das superfícies de resposta para fração gel no sistema PVP/PEG/ágar, com 5\%, $10 \% 15 \%$ e $20 \%$ PVP.

Figura 5.3 Diagrama com as linhas de contorno das superfícies de resposta para fração gel no sistema $\mathrm{PVP} /$ glicerol/ágar, com $5 \%, 10 \%, 15 \%$ e $20 \%$ PVP.

Figura 5.4 Resultados de fração gel obtidos e previstos para o sistema 3 (PVA/KC/ágar).....

Figura 5.5 - Linhas de contorno das superfícies de resposta do grau de intumescimento no equilíbrio no sistema PVA/KC/ágar, com $5 \%, 10 \%$ e $15 \%$ PVA

Figura 5.6 Resultados de intumescimento no equilíbrio, para os hidrogéis cujas composições estão apresentadas na TAB. 5.1

Figura 5.7 Linhas de contorno das superfícies de resposta geradas pelas regressões que representam o grau de intumescimento dos hidrogéis de PVP/PEG/ágar, com 5\%, 10\% e 20\% PVP.

Figura 5.8 Linhas de contorno das superfícies de resposta geradas pelas regressões que representam o grau de intumescimento para dos hidrogéis de PVP/glicerol/ágar, com 5\%, 10\%, 15\% e 20\% PVP.

Figura 5.9 Resultados de intumescimento no equilíbrio, para os hidrogéis de PVA/KC/ágar.

Figura 5.10 Linhas de contorno das superfícies de resposta do grau do grau de intumescimento no equilíbrio do sistema PVA/KC/ágar, com 5\% PVA, $10 \%$ e $15 \%$ PVA.

Figura 5.11 Resultados de resistência à tensão na ruptura, obtidos experimentalmente e preditos para os hidrogéis dos sistemas 1 e 2 .

Figura 5.12 Diagrama com as linhas de contorno para a resistência à tensão para o sistema PVP/PEG/ ágar, com 5\%, 10\%, 15\% e $20 \%$ PVP

Diagrama com as linhas de contorno para a resistência à 
Figura 5.13 tensão para o sistema PVP/glicerol/ ágar, com 5\%, 10\%, 15\% e 20\% PVP.

Figura 5.14 Resultados de tensão na ruptura medidos experimentalmente e determinados pela regressão obtida.

Figura 5.15 Diagrama das linhas de contorno da superfície de resposta para tensão, no sistema PVA/ KC/ágar, com 5\%, 10\% e 15\% PVA......

Figura 5.16 Resultados da deformação na ruptura, obtidos experimentalmente e preditos para os hidrogéis dos sistemas 1 e 2 .

Figura 5.17 Resultados de deformação na ruptura, obtidos nos ensaios de tração dos hidrogéis sintetizados, comparados aos resultados previstos pela regressão obtida.

Figura 5.18 Diagrama com as linhas de contorno da superfície de resposta do modelo obtido, para a deformação na ruptura dos hidrogéis com PVA/KC/ágar, com 5\%, 10\% e 15\% PVA.

Figura 5.19 Resultados de módulo elástico obtidos para os hidrogéis do sistema 1: PVP/PEG/ágar e sistema 2: PVP/glicerol/ágar.

Figura 5.20 Diagrama com as linhas de contorno para módulo elástico do sistema PVP/PEG/ágar, com 5\%, 10\% e 15\% PVP.

Figura 5.21 Diagrama com as linhas de contorno para módulo elástico do sistema PVP/glicerol/gar, com 5\%, 10\% e 15\% PVP.

Figura 5.22 Resultados de módulo elástico obtidos para os hidrogéis do sistema 3: PVA/KC/ágar, comparados com os resultados obtidos a partir da equação 5.15 .

Figura 5.23 Resultados da força puntiforme obtida na perfuração das membranas de hidrogel de PVP/PEG/ágar e $\mathrm{PVP} /$ glicerol/ágar.

Figura 5.24 Superfícies de contorno geradas pelas regressões 6.16 e 6.17 que representam o sistema PVP/PEG/ágar com 5\%, 10\%, 15\% e $20 \%$ PVP.

Figura 5.25 Superfícies de contorno geradas pelas regressões 6.16 e 6.17 que representam o sistema PVP/PEG/ágar com 5\%, 10\%, 15\% e $20 \%$ PVP.

Figura 5.26 Resultados de resistência puntiforme para os hidrogéis de PVA/KC/ágar.

Figura 5.27 Superfícies de contorno geradas pelas regressões 6.16 e 6.17 que representam o sistema PVP/PEG/ágar com 5\%, 10\%, 15\% e $20 \%$ PVP.

Figura 5.28 Resultados de deformação na perfuração obtidos para os hidrogéis de PVP/PEG/ágar e PVP/glicerol/ágar, comparados com os resultados preditos pelos modelos determinados. 
Figura 5.29 Linhas de contorno da superfície de resposta que representam a variação do módulo elástico, para as misturas do sistema PVP/PEG/ágar com 5\%, 10\%, 15\% e 20\% PVP...

Figura 5.30 Linhas de contorno da superfície de resposta que representam a variação do módulo elástico, para as misturas do sistema PVP/glicerol/ágar com 5\%, 10\%, 15\% e 20\% PVP.

Figura 5.31 Resultados de deformação, obtidos para o sistema 3.

Figura 5.32 Linhas de contorno da superfície de resposta para elongação na perfuração dos hidrogéis de PVA/KC/ágar com 5\%, 10\% e $15 \%$ PVA.

Figura 5.33 Amostras dos hidrogéis otimizados, preparados de acordo com a composição apresentada na TAB. 5.2, com e sem NPAg........

Figura 5.34 Espectros de ressonância plasmônica obtidos para hidrogéis de PVP/PEG/ágar, PVP/glicerol/ágar e PVA/KC/ágar

Figura 5.35 Grau de reticulação dos três hidrogéis, com e sem NPAg.

Figura 5.36 Intumescimento no equilíbrio para os três hidrogéis preparados, com e sem prata.

Figura 5.37 Tensão na ruptura dos três hidrogéis otimizados, preparados com e sem prata, comparativamente aos resultados preditos na otimização.

Figura 5.38 Deformação na ruptura dos hidrogéis com e sem NPAg quando submetidos à tração...

Figura 5.39 Resultados de módulo elástico para os três hidrogéis, preparados com e sem prata, comparativamente aos resultados preditos pela regressão.

Figura 5.40 Comparação da resistência à perfuração para os três hidrogéis otimizados, com e sem prata.

Figura 5.41 Resultados comparativos de deformação, para os hidrogéis com e sem prata, quando submetidos à perfuração.

Figura 5.42 Micrografia de fratura dos hidrogéis liofilizados, amostras de PVP/PEG/ágar, PVP/glicerol/ágar e PVA/KC/ágar, sem e com NPAg

Figura 5.43 Micrografias de MEV com EDS acoplado, mostrando a distribuição de prata na fratura e superfície de amostras de hidrogel de PVP/PEG/ágar, PVP/glicerol/ágar e PVA/KC/ágar, desidratados em estufa.

Figura 5.44 Micrografias de aglomerados de prata coloidal em superfície de hidrogel de PVA/KC/ágar observados por MEV-FEG.

Figura 5.45 Teste de sensibilidade antimicrobiana dos hidrogéis preparados com prata. 
Figura 5.46 Resultados obtidos no teste de avaliação da atividade microbiana para o hidrogel de PVP/PEG/ágar contra $P$. aeruginosa e $S$. aureus.

Figura 5.47 Resultados obtidos no teste de avaliação da atividade microbiana para o hidrogel de PVP/glicerol/ágar contra $P$. aeruginosa e $S$. aureus.

Figura 5.48 Resultados obtidos no teste de avaliação da atividade microbiana para o hidrogel de PVA/KC/ágar contra $S$. aureus para tempo de incubação de $24 \mathrm{~h}$ e $48 \mathrm{~h}$

Figura 5.49 Avaliação da citotoxicidade obtida pelo método de captura do vermelho neutro para soluções de extrato dos hidrogéis de PVP/PEG/ágar, PVP/glicerol/ágar e PVA/KC/ágar, todos com e sem NPAg. 


\section{Lista de abreviaturas e siglas}

ATCC American Type Culture Collection Bank

ANVISA Agência Nacional de Vigilância Sanitária

ASTM American Society for Testing and Materials

EDS Energy-Disperse X-Ray Spectroscopy

ELISA Enzyme Linked Immunono Sorbent Assay

FEG Field Emission Gun

FG Fração Gel

G.L. Grau de liberdade

IAEA International Atomic Energy Agency

IPN Rede polimérica interpenetrante

ISO International Organization for Standardization

KC kappa-carragena

MEM Minimum Essential Medium

MET Microscopia Eletrônica de Transmissão

MEV Microscopia Eletrônica de Varredura

NCCLS National Commitee for Clinical Laboratory Standard

NPAg Nanopartículas de prata

PBS Phosphate Buffered Saline

PEG Polietilenoglicol

PVA Poli(álcool vinílico)

PVP Poli(N-vinil-2-pirrolidona)

SEM Scanning Electron Microscopy

SIPN Rede polimérica semi-interpenetrante

SUS Sistema Único de Saúde

UFC Unidades Formadoras de Colônia 


\section{Lista de símbolos}

$\mathrm{Ag}^{\circ}$ Prata nanocristalina, prata zero ou prata coloidal

E Módulo elástico ou Módulo de Young

$\bar{E} \quad$ Módulo elástico médio

$\bar{\varepsilon}_{R}$ Deformação média na ruptura, quando tensionado

$\bar{\varepsilon}_{\mathrm{p}}$ Deformação média, na perfuração

$F_{p}$ Força puntiforme

$\bar{F}_{p} \quad$ Força puntiforme média

$\sigma \quad$ Tensão

$\bar{\sigma}_{\mathrm{m}} \quad$ Tensão máxima média

MPa Megapascal

N Newton 


\section{INTRODUÇÃO}

\section{$1.1 \quad$ Hidrogel}

Hidrogéis são redes tridimensionais constituídas por cadeias poliméricas, capazes de absorver grandes quantidades de água e fluidos biológicos em sua estrutura sem se dissolver (Peppas et al., 2000, Rosiak e Ulanski, 1999).

Dentre as propriedades que tornam os hidrogéis biomateriais importantes destacam-se: seu elevado teor de água que contribui para sua superior biocompatibilidade (Hoffman, 2002), baixa tensão interfacial entre a superfície do hidrogel e uma solução aquosa, possibilitando baixa tendência a adsorver proteínas dos fluidos corpóreos e adesão celular, propriedades físicas similares às do tecido humano, tais como a consistência macia e elástica exibida por alguns hidrogéis, minimizando a irritação mecânica por atrito; a estrutura microporosa que permite a difusão de importantes metabolitos do tecido circundante (Ratner e Hoffman, 1976) e boa permeabilidade ao oxigênio (Patel e Mequanint, 2011).

Os hidrogéis podem ser preparados por processos físicos ou químicos que envolvem reticulação por radiação ou agentes químicos (Peppas e Khare, 1993). O uso da radiação na formação de hidrogéis possibilita a reticulação e esterilização simultânea, permitindo a síntese de um produto não contaminado com resíduos tóxicos de iniciadores (Abad et al., 2003), além de ser uma tecnologia que permite a simplificação do processo de produção (Benamer et al., 2006).

\subsection{Aplicações biomédicas dos hidrogéis}

As importantes propriedades apresentadas pelos hidrogéis os tornam ideais para aplicações em lentes de contato, pílulas ou cápsulas para ingestão oral, revestimentos para implantes (Hoffman, 2002), aplicações oftálmicas, 
engenharia de tecidos (Drury e Mooney, 2003; Slaughter et al., 2009), sistemas para liberação controlada de princípios ativos (Benamer et al., 2006; Roman et al. 2010), curativos e tratamento de queimaduras e ferimentos (Pawde e Deshmukh, 2008; Rosiak et al. 1989; Varshney, 2007), assim como para a imobilização de antibióticos e cicatrizantes em curativos.

Para obtenção de hidrogéis com propriedades desejadas os polímeros podem ser modificados, tanto pela sua combinação formando blendas poliméricas quanto pela variação na proporção dos componentes na formulação.

\subsubsection{Sistema de liberação controlada de drogas}

Matrizes poliméricas de libertação controlada de fármacos podem liberar agentes terapêuticos numa taxa constante durante um determinado período, mantendo assim uma concentração constante do composto terapeuticamente ativo no sangue, com o mínimo de flutuações e com velocidades previsíveis de liberação, eliminação de efeitos colaterais e melhor adesão do paciente ao tratamento (Peppas e Khare, 1993; Simões et al., 2012).

A liberação de drogas, peptídeos e proteínas a partir de hidrogéis é controlada pela estrutura macromolecular da matriz e é definida pelo grau de reticulação, intumescimento e parâmetros relacionados (Peppas e Khare, 1993).

A FIG. 1.1 ilustra alguns hidrogéis utilizados como matriz de sistema de liberação de princípios ativos. 

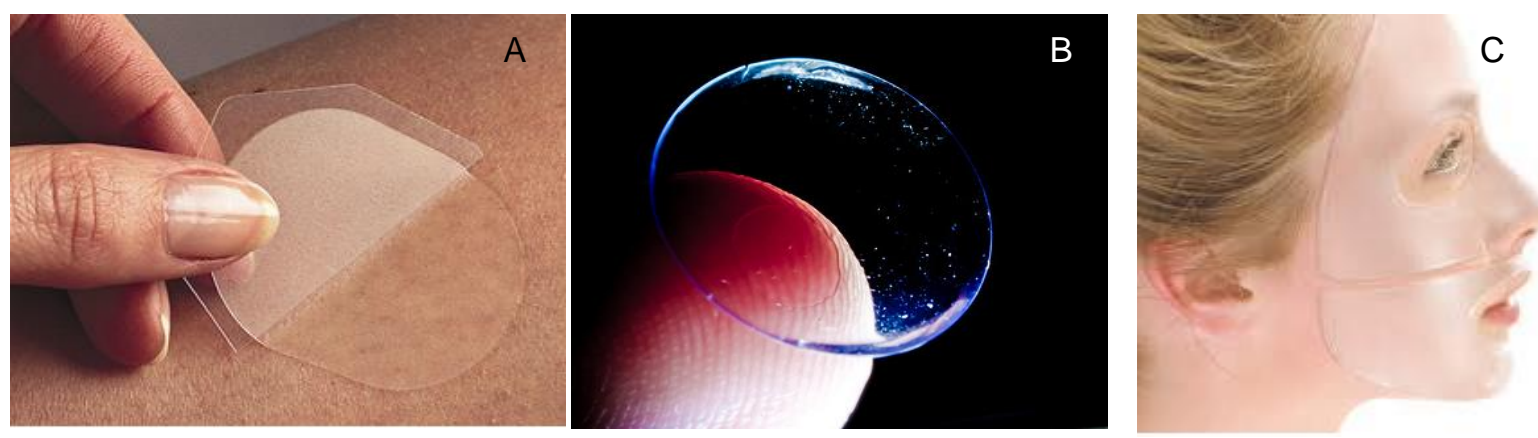

FIGURA 1.1 - Imagens ilustrativas de hidrogéis utilizados como sistema de liberação de principios ativos. (A) Sistema de liberação transdérmica de droga, (B) Sistema de liberação ocular, (C) máscara de liberação de ativo cosmético.

\section{Fontes:}

(A) 3M. Transdermal drug delivery (TDD) products. Disponível em:

$<$ http://solutions.3m.com/wps/portal/3M/en US/Northridge/Plant/Facility/Produ ct/ > . Acesso em 30 set. 2012.

(B) Optyk Rozmus; Harrison, Joel. Popular contact lens material investigated as means of medicine delivery, 2012. Disponível em:

$<$ http://www.optykrozmus.co.uk/Contact-Lens-News-and-

Information/post/2012/05/23/Popular-Contact-Lens-Material-Investigated-asMeans-of-Medicine-Delivery.aspx>. Acesso em 30 set. 2012.

(C) Korea Buyers Guide. Temperature-sensitive, water-soluble hydrogel mask. 2012. Disponível em: $<$ http://korean-products.com/2012/01/07/temperaturesensitive-water-soluble-hydrogel-mask/>. Acesso em 30 set. 2012.

\subsubsection{Curativos}

Os curativos convencionais têm como objetivo recobrir a lesão após sua limpeza diária e os curativos interativos geralmente são permeáveis a vapor d'água e oxigênio e impermeáveis a bactérias, absorvendo o exsudato da ferida, enquanto que os bioativos liberam substâncias ativas na cicatrização da ferida. $\mathrm{Na}$ FIG. 1.2 são mostradas algumas lesões recobertas com curativos de hidrogéis. 

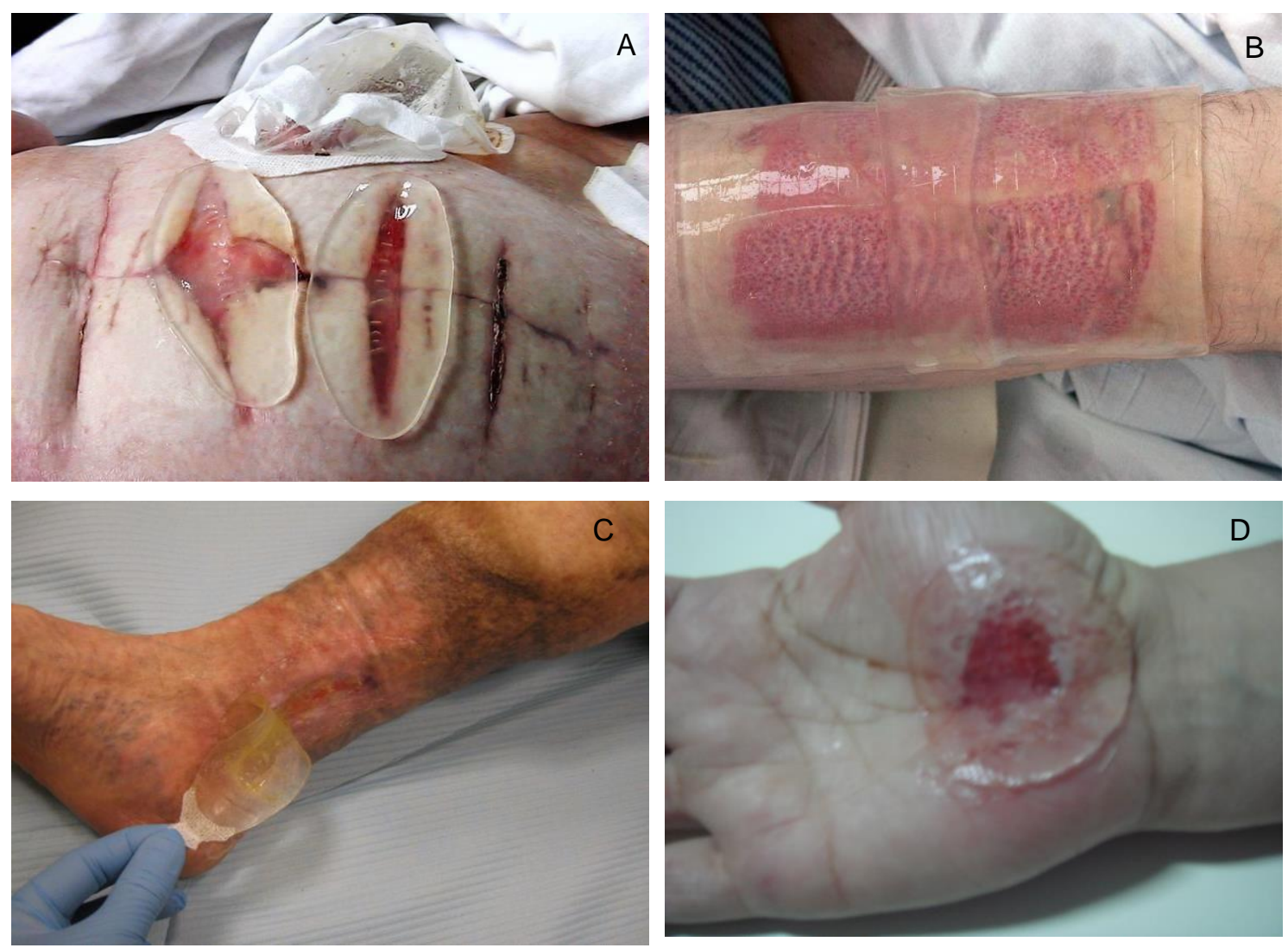

FIGURA 1.2 - Imagens ilustrativas de lesões com curativos de hidrogel. (A) Corte cirúrgico, (B) ferimento em região doadora de pele, (C) ferida de difícil cicatrização, (D) ferimento acidental.

Fontes:

(A) e (B) Fhrichard. Hydrogel dressing sterile. Disponível em: $<$ http://gulfbusiness.tradeholding.com/default.cgi/action/viewprod ucts/productid/44395/productname/Hydrogel dressing sterile/>. Acesso em 07 nov. 2012.

kikgel. Aqua-gel ${ }^{\circledR}$. Disponível em: <http://kikgel.com.pl/?p=114>. Acesso em 30 set. 2012.

(D)

Autora do trabalho. Obtida em jun. 2010.

Entre os curativos disponíveis, vários hidrogéis foram desenvolvidos para aplicação em feridas e queimaduras (Rosiak,1989, Escobar, 2002; Varshney, 2007), tendo em vista a baixa tensão interfacial entre a sua superfície e os fluidos fisiológicos ajudando a minimizar a adesão celular (Benamer, 2006), biocompatibilidade com sangue, fluidos corpóreos e tecidos biológicos, prevenção da perda de fluidos corporais, barreira contra bactérias e permeabilidade ao oxigênio (Peppas, 2000). 
A reparação tecidual é um processo sistêmico, no entanto é necessário favorecer as condições locais para viabilizar o processo fisiológico. Recomendase, para isso, fechar espaços mortos, absorver o excesso de exsudato, manter o leito da ferida úmido, promover isolamento térmico e proteger a ferida de traumas e invasão bacteriana (Blanes, 2004), além de permitir a troca gasosa para oxigenação e sucesso na reparação do tecido (Winter, 1962).

Dentre as vantagens da manutenção do meio úmido destacam-se a prevenção da desidratação do tecido e da morte celular, a formação acelerada dos vasos sanguíneos (angiogênese), a redução da dor devido à proteção que o meio úmido fornece às terminações nervosas do ressecamento e exposição. Em meio úmido a reepitelização em feridas é mais rápida do que em meio seco (Winter, 1962), uma vez que o meio úmido propicia a manutenção da viabilidade do tecido exposto e da vasculatura e permite que as células viáveis liberem fatores de crescimento estimulando sua proliferação (Field e Kerstein, 1994).

Os hidrogéis atendem todos os requisitos que favorecem a epitelização de lesões e ainda podem liberar substâncias ativas para estimular o processo de cicatrização, evitar ou combater infecções tendo em vista que a infecção é o maior inimigo da cura de uma ferida, pois determina uma maior destruição de tecidos e prolonga a fase inflamatória, retardando a reparação tecidual (Blanes, 2004) ou ainda tratar doenças (Oliveira et al., 2009).

No ano de 2011, o SUS realizou 207.037 procedimentos ambulatoriais e 25.811 procedimentos hospitalares relacionados à assistência ao paciente com queimaduras, totalizando um valor gasto superior a 55 milhões (Ministério da saúde, 2012). Todos os anos milhões de pessoas morrem de queimaduras graves e a maioria dessas mortes é devida aos problemas que se seguem, devido à perda da integridade da pele e à invasão microbiana. Na FIG. 1.3 estão apresentadas queimaduras de diferentes graus. 

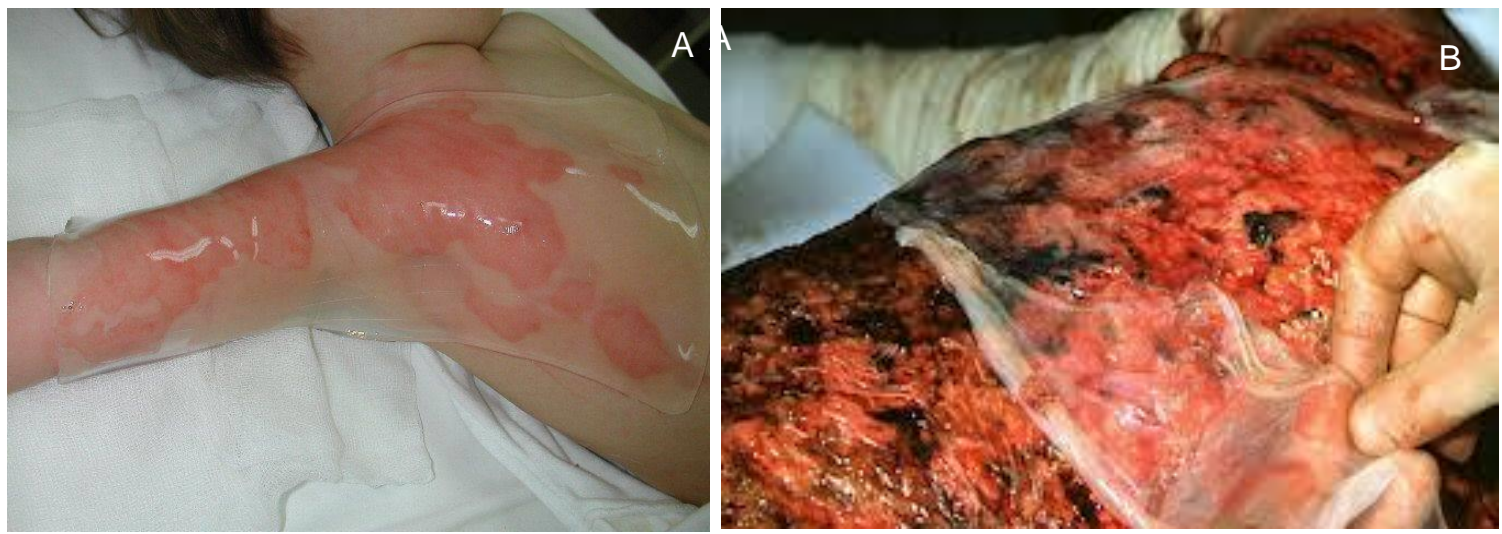

FIGURA 1.3 - Imagens ilustrativas de diferentes graus de queimadura, recobertas com curativo.

Fontes:

(A) Fhrichard. Hydrogel dressing sterile. Disponível em: $<$ http://gulfbusiness.tradeholding.com/default.cgi/action/viewproducts/produ ctid/44395/productname/Hydrogel_dressing_sterile/>. Acesso em 07 nov. 2012.

(B) Stevenson, J. Dressing of third degree burns with amnion. Science photo library, M335/0010. Disponível em:

<http://www.sciencephoto.com/media/265613/enlarge>. Acesso em 30 set. 2012.

Infecção em paciente queimado é uma das principais causas de morbidade e mortalidade (Weber e McManus, 2004) tendo em vista que pode haver a disseminação de agentes infecciosos pela corrente sanguínea, o que é uma situação delicada quando diagnosticada no paciente queimado em regime de internamento hospitalar (Veronesi et al., 2006). A FIG. 1.4 ilustra queimadura e ferimento infectados. 

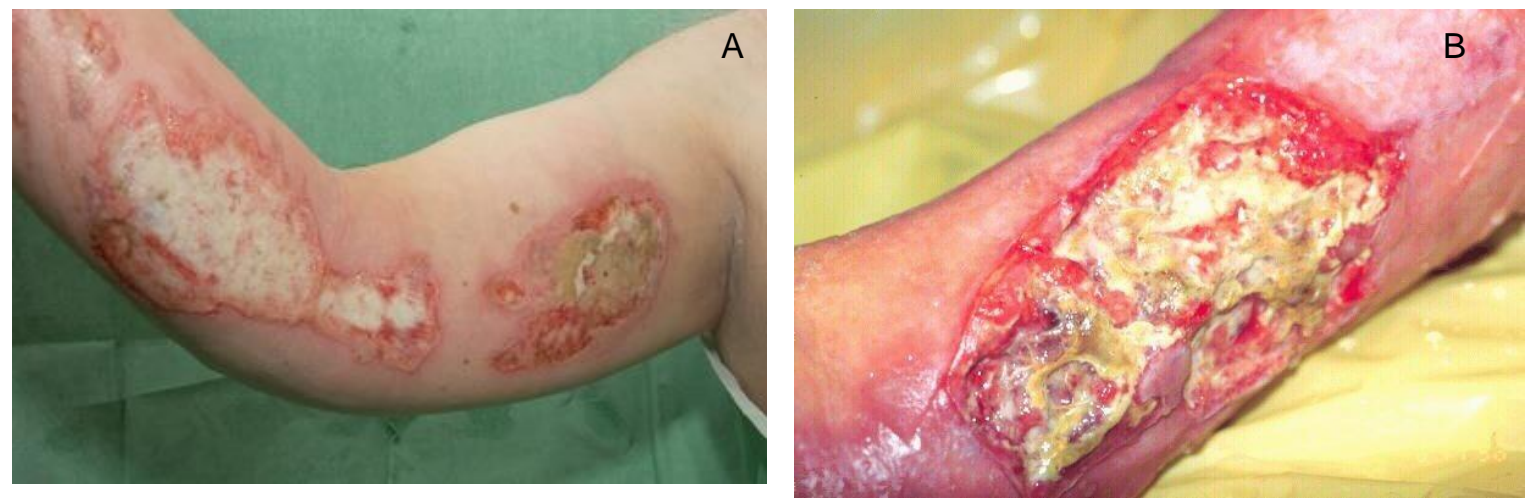

FIGURA 1.4 - Imagens ilustrativas de lesões infectadas (A) queimadura e (B) ferida.

Fontes:

(A) British Association of Plastic Reconstructiveand Aesthetic Surgeons.

Burns - patient information guide. Disponível em

<http://www.bapras.org.uk/guide.asp?id=328>. Acesso em 07 nov. 2012.

(B) Meu fiel enfermeiro. Tipos de feridas. 2010. Disponível em $<$ http://fielenfermeiro.wordpress.com/2010/06/22/tipos-de-feridas/>. Acesso em 07 nov. 2012.

Estudo realizado na Unidade de Terapia Intensiva de Queimaduras do Hospital das Clínicas da Universidade de São Paulo, entre 1993 e 1999, indicou que o Staphylococcus aureus (gram-positivo) e a Pseudomonas aeruginosa (gram-negativa) são os principais patógenos encontrados em infecções de feridas de pacientes queimados, sendo que tanto organismos gram-positivos quanto gram-negativos exibiram resistência à maioria dos agentes antimicrobianos usados para terapia (Santucci et al., 2003; Neves et al., 2011).

As bactérias resistentes a antibióticos representam uma preocupação crescente (Todar, s.d.; Neves et al., 2011) nas infecções de ferida (Wright et al., 1998) e a utilização de prata nanocristalina é defendida no tratamento de queimaduras nas quais as infecções são conhecidas pela sua intolerância e resistência a antibióticos. Além da excelente propriedade bactericida, as NPAg também se mostraram favoráveis na minimização da resposta inflamatória local facilitando a cicatrização das feridas (Nair e Laurencin, 2007; Tian et al., 2007).

Apesar dos inúmeros estudos ressaltando os benefícios do uso de NPAg, também existem outros que mostram não haver evidência suficiente de que curativos de prata melhoram as taxas de cura (Michaels, et al., 2009; Vermeulen et al., 2007; Storm-Versloot, 2010), o que tem levado os médicos a uma crescente preocupação quanto a uma retirada arbitrária de curativos de prata do 
mercado e um consequente aumento da morbidade e tempo de tratamento prolongado relativos à ferida. Tendo em vista recentes revisões sistemáticas, confirmando os efeitos positivos de curativos de prata quando usados adequadamente (Lo et al., 2008; Lo et al., 2009; Carter et. al., 2010) e a riqueza de experiência clínica positiva de muitos médicos, um grupo de especialistas da Europa, América do Norte, Extremo Oriente, África do Sul e Austrália se reuniram para fornecer orientações internacionalmente reconhecidas para a correta utilização de curativos de prata, com base na experiência clínica e em todas as evidências disponíveis (International Consensus, 2012).

Entretanto, a atividade bactericida de diferentes produtos varia bastante (Wright et al., 1998; NG, 2008). As variedades entre os diferentes curativos contendo prata se diferenciam basicamente pela forma como ela está disposta no curativo. Alguns liberam quantidades mínimas de prata enquanto outros liberam doses excessivas, no entanto, não conseguem manter a liberação constante (Hollinger, 1996).

\subsection{Curativos de hidrogel reticulados por radiação}

O polímero precursor da ampla classe de materiais conhecidos hoje como hidrogéis, foi o poli(álcool vinílico) PVA, reticulado com formaldeído (Rosiak et al., 1995), que recebeu o nome de Ivalon ${ }^{\top M}$ e foi utilizado pela primeira vez na área médica em 1949 e, em 1960, como substituto de pele em pacientes com queimaduras (Tadavarthy et al., 1975).

No início dos anos cinquenta, Arthur Charlesby reportou que a radiação poderia reticular vários polímeros, entretanto tais polímeros foram analisados apenas sob o ponto de vista de fenômenos associados com a síntese por radiação (Rosiak e Yohii, 1999). O poli ( $N$-vinil-2-pirrolidona) (PVP) em solução aquosa foi reticulado pela primeira vez por Charlesby e Alexander em 1955 (Charlesby e Alexander, 1955).

O primeiro hidrogel sintético, proposto para uso em lente de contato foi produzido em 1960 por Otto Wichterle e Drahoslav Lim e consistia de metacrilato de 2-hidroxietila (HEMA), reticulado com menos de $3 \%$ de dimetacrilato de etilenoglicol (EDMA) (Kopecek, 2009) e veio despertar o interesse dos 
pesquisadores para os hidrogéis devido ao seu caráter hidrofílico e potencialmente biocompatível. (Peppas, 1997; Li, 2009).

O interesse para obtenção de hidrogéis reticulados por radiação, para fins biomédicos, começou nos anos 60 como resultado dos trabalhos e patentes da equipe de Kaetsu, da Takasaki Radiation Chemistry Research Establishment, no Japão, e de Hoffman do Centro de Bioengenharia da Universidade de Washington, nos EUA. O objeto dos estudos foi voltado para a imobilização de espécies biologicamente ativas em matrizes de hidrogel e sua utilização como sistemas de liberação de drogas e captura de enzimas, bem como para a modificação das superfícies de materiais para melhorar a sua biocompatibilidade e capacidade de ligação aos antígenos e anticorpos (Rosiak et al., 1995; Rosiak et al.,1999).

No entanto, o primeiro hidrogel, reticulado por radiação e esterilizado simultaneamente, para aplicação como curativo, foi desenvolvido por Janusz M. Rosiak et al. em 1989, na Polônia. Embora tenha sido inicialmente proposto para aplicação em queimadura, desde o início de sua comercialização, com o nome de $\mathrm{HDR}^{\mathrm{TM}}$, Aqua-gel ${ }^{\mathrm{TM}}$, ou Kik-gel ${ }^{\mathrm{TM}}$, também tem sido utilizado para tratamento de outros tipos de lesões (Rosiak et al., 1989).

O hidrogel desenvolvido por Rosiak et al. é uma blenda polimérica de poli(N-vinil-2-pirrolidona) (PVP), polietilenoglicol (PEG) e ágar; apresenta boa biocompatibilidade, efetiva absorção de fluidos e prevenção de sua perda, age como eficiente barreira contra bactérias, exibe alta elasticidade, mostra boa transparência, permite a passagem de oxigênio, o manuseio sem dor e geralmente acelera a cicatrização (Rosiak et al., 1989).

Tendo em vista o crescente interesse da IAEA na aplicação de radiação para bioengenharia, esta apoiou programas internacionais relativos a estudos e convidou o Prof. Rosiak a apoiar a transferência da tecnologia desenvolvida para muitos laboratórios ao redor do mundo, entre os quais os laboratórios do IPEN, no Brasil (Rosiak et al., 1995; Lugão e Malmonge, 2001). Devido ao seu potencial, diversos estudos foram efetuados referentes à blenda proposta por Rosiak (Hilmy et al., 1993; Miranda, 1999; Lugão et al, 1998; Lopérgolo, 2002a, 2002b; Ajji et al., 2005; Ajji et al., 2008; Benamer et al., 2006; Momesso et al.; 2010; Machado, 2010; Amaral, 2009). 
Outro exemplo de sucesso com hidrogel reticulado por radiação é o do hidrogel à base de PVA e polissacarídeos naturais como ágar e carragena, desenvolvido por Varshney e Majmudar (1999), na Índia, em função da necessidade de desenvolver um curativo avançado para atender as exigências locais usando ingredientes locais e econômicos, tendo em vista os custos proibitivos para importação e o grande número de casos de queimaduras e úlceras no país. 


\section{OBJETIVOS}

O presente trabalho teve como objetivos principais o estudo sistemático de algumas propriedades de hidrogéis à base de blendas poliméricas, por meio de planejamento estatístico, para futuros desenvolvimentos que envolvam sistemas de liberação de drogas hidrofílicas e lipofílicas, além da otimização de membranas e síntese de nanopartículas de prata, in situ, por radiação ionizante, para aplicação como curativos de ferimentos/queimaduras infectados.

\subsection{Originalidade}

A originalidade desse trabalho consiste no estudo sistemático de algumas propriedades de hidrogéis à base de blendas poliméricas, compostas por PVP/PEG/ágar, PVP/glicerol/ágar e PVA/KC/ágar, reticulados e esterilizados simultaneamente por radiação ionizante, utilizando planejamento de misturas para estudo de suas propriedades, do efeito do plastificante e gelificante. A partir das composições otimizadas foram preparados hidrogéis com nanopartículas de prata, sintetizadas in situ, para aplicação como curativos de ferimentos/queimaduras infectados e finalmente foi avaliado o comportamento biocida dos hidrogéis com nanopartículas de prata.

Apesar da grande quantidade de publicações no tema, não há estudo desta natureza com hidrogéis e em particular com os sistemas propostos, assim como apesar da existência de inúmeros estudos e produtos biocidas no mercado - à base de prata coloidal, não é do nosso conhecimento a síntese de nanopartículas de prata, in situ, em blendas poliméricas. 


\section{REVISÃO BIBLIOGRÁFICA}

\subsection{Biomateriais poliméricos}

O termo biomaterial é definido como qualquer substância (outra que não a droga) ou combinação de substâncias, sintética ou natural em origem, que possa ser usada por um período de tempo, completa ou parcialmente como parte de um sistema que trate, aumente ou substitua qualquer tecido, órgão ou função do corpo" (Williams, 1987).

Devido aos avanços da ciência e tecnologia, resultantes dos esforços conjuntos de químicos, cientistas de materiais, engenheiros e médicos, os biomateriais políméricos se tornaram componentes essenciais na fabricação de dispositivos ortopédicos, cardiovasculares e dentais. $\mathrm{Na}$ indústria farmacêutica são utilizados no desenvolvimento de matrizes para incorporação de drogas e em sistemas de liberação controlada destas. (Deng e Shalaby, 2001).

Tanto os polímeros naturais quanto os sintéticos são muito versáteis e entre as vantagens oferecidas destacam-se suas diferentes propriedades físicas e químicas. Os polímeros sintéticos podem ser fabricados em diferentes formas, tais como fibras, películas, folhas, varetas, tubos e líquidos viscosos (Deng e Shalaby, 2001). Além disso, a partir da mistura de dois ou mais polímeros é possível obter produtos com certas propriedades desejadas, exibidas individualmente por cada um dos polímeros (Paul, 1985).

Entre os biomateriais poliméricos destacam-se os hidrogéis e estes podem ser preparados sob a forma de esponjas porosas, géis, películas, líquidos que podem ser subsequentemente reticulados para formar géis em revestimentos ligados a substrato. A composição de um hidrogel pode ser substancialmente alterada em sua formulação e composição para responder a cada utilização biomédica (Ratner e Hoffman, 1976). A adequação dos hidrogéis e o seu desempenho para uma aplicação particular dependerá da sua composição (Peppas et al., 2006). 


\subsection{Hidrogéis}

Hidrogéis são sistemas bi ou multicomponentes formados por uma rede tridimensional de cadeias poliméricas e água, que preenche o espaço entre as macromoléculas. Dependendo das propriedades do(s) polímero(s) usado(s), bem como a natureza e densidade das ligações da rede, tais estruturas em equilíbrio podem conter diferentes quantidades de água (Rosiak e Ulansky, 1999).

A capacidade dos hidrogéis para absorver e reter grande quantidade de água é devida à presença de grupos funcionais hidrofílicos na sua estrutura, tais como $-\mathrm{OH},-\mathrm{COOH},-\mathrm{CONH}_{2},-\mathrm{SO}_{3} \mathrm{H}$ (Patel e Mequanint, 2011). A sua insolubilidade e estabilidade se deve à sua rede tridimensional.

\subsubsection{Classificação dos hidrogéis}

Os hidrogéis podem ser classificados em várias categorias, conforme apresentado na FIG. 3.1, porém entre elas a classificação considerada mais importante baseia-se na sua natureza de reticulação (Patel e Mequanint, 2011).

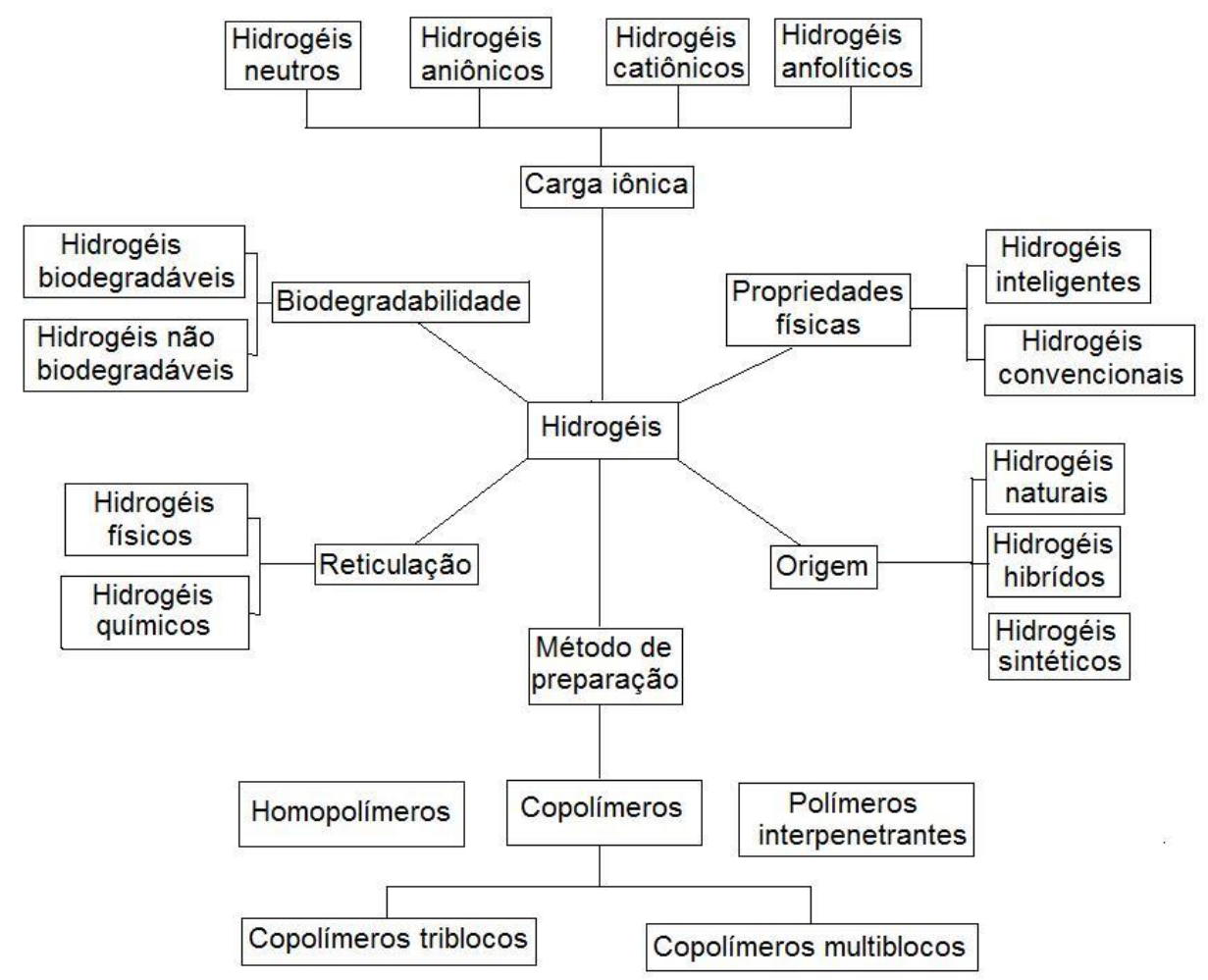

FIGURA. 3.1 - Classificação dos hidrogéis.

Fonte: Patel e Mequanint, 2011. Traduzido pela autora. 


\subsubsection{Estrutura dos hidrogéis}

Os hidrogéis podem apresentar redes poliméricas interpenetrantes (IPNs) ou semi-IPNs (SIPNs). As redes SIPNs são formadas por dois ou mais polímeros onde pelo menos um deles está reticulado, sendo um polímero reticulado e entrelaçado a um segundo não reticulado. Os hidrogéis de IPNs apresentam redes individuais reticuladas e entrelaçadas entre si (Suri e Schmidt, 2009).

Os hidrogéis em geral apresentam propriedades mecânicas pobres, quando comparados aos demais materiais poliméricos (Lopes, 2003), no entanto, a presença de dois polímeros pode resultar no aumento da resistência mecânica do hidrogel devido à presença de redes altamente emaranhadas.

\subsubsection{Porosidade}

O tamanho dos poros torna os hidrogéis ideais como veículos para liberação de ativos farmacêuticos, uma vez que diferentes medicamentos podem ser imobilizados e liberados com velocidades diferentes para diferentes intervalos de tempo (Lowman et al., 2004). A estrutura da rede dos hidrogéis pode ser macroporosa, microporosa ou não porosa.

Hidrogéis macroporosos apresentam grandes poros, com dimensão variando de 0,1 a $1,0 \mu \mathrm{m}$. Hidrogéis microporosos possuem pequeno tamanho de poro, geralmente entre 100-1000 A. Quando o tamanho do poro se assemalha ao tamanho dos solutos de difusão a liberação do fármaco ocorre devido a uma combinação de difusão molecular e de convecção nos poros cheios de água. Hidrogéis não porosos são os que apresentam tamanhos de poro com dimensão macromolecular (६) entre 10 - $100 \AA$. As cadeias poliméricas destes hidrogéis são densas e apresentam transporte de solutos estritamente limitados, por difusão através das áreas livres (Ganji et al., 2010).

\subsubsection{Cristalinidade}

Hidrogéis amorfos apresentam cadeias poliméricas dispostas aleatoriamente e emaranhadas, enquanto que nos hidrogéis semicristalinos as cadeias apresentam um empacotamento ordenado em determinadas regiões, ou seja, observa-se a presença de cristalitos.

Os polímeros semicristalinos são mais duros e resistentes devido às fortes interações intermoleculares; como as regiões cristalinas espalham a luz, estes 
polímeros são mais opacos enquanto que os polímeros amorfos geralmente são mais macios e transparentes (Hoffman, 2012).

\subsubsection{Intumescimento}

O intumescimento pode ser descrito como a quantidade de água absorvida pelo hidrogel. O equilíbrio de intumescimento e a variação dimensional do hidrogel são controlados pelo equilíbrio hidrofílico/ hidrofóbico do hidrogel, pela densidade de reticulação e pelas interações intermoleculares entre os segmentos do polímero e as moléculas do solvente. Estes fatores também definem o perfil de liberação de fármacos quando estes são imobilizados em matrizes de hidrogel.

Uma das características importantes no intumescimento do hidrogel é a taxa ou cinética de intumescimento; esta é determinada pelo tamanho da amostra, pela extensão da porosidade, tipo da estrutura porosa, temperatura e mudança de $\mathrm{pH}$, entre outros. O equilíbrio no intumescimento se dá pela estabilidade alcançada entre a força osmótica, que favorece a absorção do solvente e a força elástica oposta que equilibra o estiramento da rede polimérica e impede sua deformação (Ganji et al., 2010).

\subsubsection{Preparação de hidrogéis}

Os hidrogéis podem ser preparados com polímeros sintéticos, naturais ou blendas mistas (Gupta, et al., 2002) a partir de diferentes mecanismos de gelificação (Gulrez et al., 2011; Hennink e Nostrum, 2002). Nestes casos eles podem ser classificados como géis físicos ou reversíveis e géis químicos ou permanentes.

Os géis físicos apresentam ligações formadas a partir de associações reversíveis entre as cadeias, cujas redes estão ligadas por emaranhamentos moleculares e/ou forças secundárias como interações iônicas, hidrofóbicas ou ligações de hidrogênio. Todas essas interações podem ser rompidas por mudanças nas condições físicas ou aplicação de tensão (Rosiak e Yoshii, 1999; Gulrez et al., 2011). Nestes casos, os géis formados podem ser limitados pelas suas propriedades mecânicas (Huang et al., 2007).

Os hidrogéis químicos ou permanentes são formados por redes unidas por ligações covalentes (Gulrez et al., 2011 e Rosiak e Ulansk, 1999) e podem ser 
preparados por reticulação química, fotopolimerização e radiação (Peppas et al., 2000).

Os hidrogéis preparados por reticulação química muitas vezes são limitados para as aplicações médicas, uma vez que os agentes de reticulação utilizados, além de serem compostos altamente tóxicos, também podem afetar a integridade das substâncias a serem imobilizadas (Hennink e Nostrum, 2002).

A preparação de hidrogéis por radiação ionizante possibilita a reticulação e esterilização simultânea, permitindo a síntese de um produto puro, não contaminado com resíduos tóxicos de iniciadores (Abad et al., 2003); além disso, o produto irradiado continua estéril até que sua embalagem seja rompida. (Aquino, 2012). Entretanto é necessário lembrar que a radiação pode alterar algumas substâncias biologicamente ativas (Hennink e Nostrum, 2002), se estas forem imobilizadas no hidrogel antes de ser reticulado.

\subsection{Radiação ionizante}

Radiação é a unica fonte de energia que pode iniciar reações químicas a qualquer temperatura, sob qualquer pressão e em qualquer fase (gás, líquido ou sólido), sem a utilização de catalisadores (Aquino, 2012).

Raios gama são radiações eletromagnéticas com comprimento de onda na região de $3 \times 10^{-11} \mathrm{~cm}$ a $3 \times 10^{-9} \mathrm{~cm}$. As principais fontes são o cobalto-60 $\left({ }^{60} \mathrm{Co}\right)$ e o césio-137 ( $\left.{ }^{137} \mathrm{Cs}\right)$, sendo ${ }^{\circ}{ }^{60} \mathrm{Co}$ o mais comum. $\mathrm{O}{ }^{60} \mathrm{Co}$ é produzido pelo bombardeamento do ${ }^{59} \mathrm{Co}$ por nêutrons, e a desintegração de cada átomo emite uma partícula beta com energia de até 0,3 milhão de elétron-volts $(\mathrm{MeV})$, dois fótons gama com energia de 1,17 e 1,33 MeV e é produzido um átomo de níquel60 estável (Chapiro, 1962; Spinks e Wood, 1964).

A interação da radiação com a máteria pode levar a grandes alterações nos materiais durante ou até mesmo depois de dias, semanas ou meses. A irradiação de polímeros com radiação ionizante de alta energia (raios gama, raios $X$, feixe de elétrons e feixes de íons) leva a formação de muitos intermediários (Güven, 2004). As condições ambientais em que a radiação é processada pode afetar significativamente o resultado final da interação da radiação com o polímero. A presença de oxigênio durante a irradiação produz radicais livres, que são muitas vezes rapidamente convertidos em radicais peróxidos. $O$ destino desses radicais depende da natureza do polímero irradiado, da presença de aditivos e de outros 
parâmetros, tais como temperatura, dose total, taxa de dose e tamanho da amostra (Spinks e Woods, 1964; Dorati et al., 2008).

As espécies geradas radioliticamente a partir da radiólise da água exibem forte poder redutor e por isso a radiação gama também tem sido empregada na redução de íons de metais para síntese de nanopartículas em solução, em especial para síntese de nanopartículas de prata (Shin et al., 2004; Beloni, 2006; Javanovic et al., 2012) uma vez que apresenta a vantagem de reduzir os íons à temperatura ambiente sem utilizar agentes redutores ou gerar subprodutos indesejados (Sheikha et al., 2009).

\subsubsection{Interação da radiação de alta energia com os polímeros}

A passagem de um fóton de alta energia ou de partículas através da matéria produz uma série complexa de processos que resultam na dissipação da energia inicial. $\mathrm{O}$ mecanismo de perda de energia mais importante em polímeros é através do efeito Compton, no qual o fóton interage com um elétron, resultando na ejeção de elétrons e na deflexão do fóton, com redução de energia. A probabilidade de dispersão do fóton e a energia resultante do elétron ejetado dependem da energia com que o fóton incide e da densidade eletrônica do material que ele atravessa (Hill e Whittaker, 2005).

No efeito fotoelétrico toda a energia do fóton é transferida para um único elétron que é ejetado com energia igual à energia do fóton incidente menos a energia de ligação dos elétrons. A formação de pares, de importância apenas quando os fótons incidentes têm energia maior que 1,02 MeV, envolve a absorção completa da energia do fóton incidente e resulta na formação de duas partículas, o pósitron e o elétron. A combinação das duas partículas resulta na emissão de dois rais $\mathrm{y}$ com $0,51 \mathrm{MeV}$, que podem interagir novamente com a matéria (Hill e Whittaker, 2005).

A irradiação da matéria com fótons de alta energia pode ser resumida da seguinte forma (Hill e Whittaker, 2005):

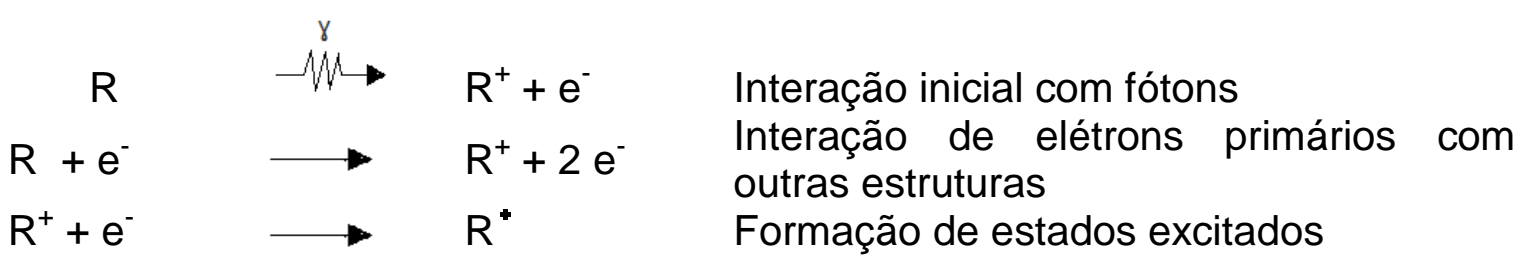

FIGURA 3.2 - Interação dos fótons de alta energia com a matéria orgânica. 
A interação da radiação com os polímeros pode resultar em oxidação, enxertia, reticulação ou degradação, sendo que o mecanismo de reticulação e cisão de cadeia normalmente ocorrem simultaneamente (Chapiro, 1962). O resultado dessas reações varia de polímero para polímero e depende da composição química, da estrutura do polímero, da dose total de radiação absorvida, da taxa em que a dose foi fornecida, das condições do ambiente em que a radiação foi realizada antes, durante e após a irradiação (Gueven, 2004).

\subsubsection{Radiólise da água}

Num sistema aquoso, a água é quem recebe grande parte da energia da radiação absorvida. As alterações químicas dos solutos ocorrem quando estes reagem com os produtos da radiólise da água. A FIG. 3.3 apresenta alguns produtos formados a partir da radiólise da água (Spinks e Woods, 1964 e 1990).

$$
\begin{aligned}
& \mathrm{H}_{2} \mathrm{O} \stackrel{\gamma}{\longrightarrow} \mathrm{H}^{*}+\mathrm{OH}^{*} \\
& \mathrm{H}_{2} \mathrm{O} \stackrel{\gamma}{\longrightarrow} \mathrm{H}_{2} \mathrm{O}^{+}, \mathrm{e}^{-}, \mathrm{H}_{2} \mathrm{O}^{*} \\
& \mathrm{H}_{2} \mathrm{O}+\mathrm{e} \longrightarrow \mathrm{H}^{*}+\mathrm{OH}^{-} \\
& \mathrm{H}_{2} \mathrm{O}^{+}+\mathrm{H}_{2} \mathrm{O} \longrightarrow \mathrm{H}_{3} \mathrm{O}^{+}+\mathrm{OH} \\
& \mathrm{H}_{2} \mathrm{O}^{*} \longrightarrow[\mathrm{H}+\mathrm{OH}] \longrightarrow \mathrm{H}_{2} \mathrm{O} \\
& \mathrm{e}^{-} \longrightarrow \mathrm{e}_{\mathrm{aq}}^{-} \\
& \mathrm{e}_{\mathrm{aq}}^{-}+\mathrm{H}_{2} \mathrm{O} \longrightarrow \mathrm{H}+\mathrm{OH}^{-} \quad k=0,0193 \mathrm{~m}^{3} \mathrm{~mol}^{-1} \mathrm{~s}^{-1} \\
& 2 \mathrm{e}_{\mathrm{aq}}^{-} \longrightarrow \mathrm{H}_{2}+2 \mathrm{OH}^{-} \quad k=5,5 \times 10^{6} \mathrm{~m}^{3} \mathrm{~mol}^{-1} \mathrm{~s}^{-1} \\
& \mathrm{e}_{\mathrm{aq}}^{-} \mathrm{H} \longrightarrow \mathrm{H}_{2}+\mathrm{OH}^{-} \quad k=2,5 \times 10^{7} \mathrm{~m}^{3} \mathrm{~mol}^{-1} \mathrm{~s}^{-1} \\
& \mathrm{e}^{-} \mathrm{aq}+\mathrm{OH} \longrightarrow \mathrm{OH}^{-} \quad k=3,0 \times 10^{7} \mathrm{~m}^{3} \mathrm{~mol}^{-1} \mathrm{~s}^{-1} \\
& \mathrm{e}_{\mathrm{aq}}^{-}+\mathrm{H}_{3} \mathrm{O}^{+} \longrightarrow \mathrm{H}+\mathrm{H}_{2} \mathrm{O} \quad k=2,3 \times 10^{7} \mathrm{~m}^{3} \mathrm{~mol}^{-1} \mathrm{~s}^{-1} \\
& 2 \mathrm{H}^{*} \longrightarrow \mathrm{H}_{2} \quad k=7,8 \times 10^{6} \mathrm{~m}^{3} \mathrm{~mol}^{-1} \mathrm{~s}^{-1} \\
& \mathrm{H}^{*}+{ }^{*} \mathrm{OH} \longrightarrow \mathrm{H}_{2} \mathrm{O} \quad k=7,0 \times 10^{6} \mathrm{~m}^{3} \mathrm{~mol}^{-1} \mathrm{~s}^{-1} \\
& 2^{\circ} \mathrm{OH} \longrightarrow \mathrm{H}_{2} \mathrm{O}_{2} \quad k=5,5 \times 10^{6} \mathrm{~m}^{3} \mathrm{~mol}^{-1} \mathrm{~s}^{-1} \\
& \cdot \mathrm{OH}+\mathrm{H}_{2} \mathrm{O}_{2} \longrightarrow \mathrm{H}_{2} \mathrm{O}+\mathrm{HO}_{2}^{*} \quad k=2,7 \times 10^{4} \mathrm{~m}^{3} \mathrm{~mol}^{-1} \mathrm{~s}^{-1} \\
& 2 \mathrm{HO}_{2}{ }^{*} \longrightarrow \mathrm{H}_{2} \mathrm{O}_{2}+\mathrm{O}_{2} \quad k=830 \mathrm{~m}^{3} \mathrm{~mol}^{-1} \mathrm{~s}^{-1} \\
& \mathrm{H}_{3} \mathrm{O}^{+}+\mathrm{OH}^{-} \longrightarrow 2 \mathrm{H}_{2} \mathrm{O} \quad k=1,43 \times 10^{8} \mathrm{~m}^{3} \mathrm{~mol}^{-1} \mathrm{~s}^{-1}
\end{aligned}
$$

FIGURA 3.3 - Produtos mais importantes formados pela radiólise da água no estado líquido. 


\subsubsection{Efeito da radiação em sistemas aquosos}

As reações em sistemas aquosos, como é o caso dos hidrogéis, ocorrem entre o soluto e os produtos primários da radiólise da água. Na FIG. 3.4 estão apresentados os mecanismos de radiólise para soluções de compostos orgânicos contendo grupos funcionais $\mathrm{OH}$, compostos orgânicos nitrogenados, compostos insaturados e aromáticos, entre outros. Os produtos primários da água $\left(\mathrm{e}_{\mathrm{aq}}^{-}, \mathrm{H}^{*} \mathrm{e}\right.$ $\mathrm{OH}^{*}$ ) tendem a reagir com os grupos funcionais presentes na molécula orgânica ao invés da molécula como um todo. Alguns grupos, tais como carbonetos contendo insaturação tendem a dominar as reações de radiólise se estiverem presentes, enquanto outros grupos funcionais permitem o ataque dos radicais em vários pontos no interior da molécula alvo (Spinks e Woods, 1990).

$$
\begin{aligned}
& \mathrm{e}_{\mathrm{aq}}^{-}+\mathrm{H}^{+} \longrightarrow \mathrm{H} \quad k=2,3 \times 10^{7} \mathrm{~m}^{3} \mathrm{~mol}^{-1} \mathrm{~s}^{-1} \\
& \mathrm{e}^{-} \mathrm{aq}+\mathrm{O}_{2} \longrightarrow \mathrm{O}_{2}^{-} \quad k=1,9 \times 10^{7} \mathrm{~m}^{3} \mathrm{~mol}^{-1} \mathrm{~s}^{-1} \\
& \mathrm{H}+\mathrm{O}_{2} \longrightarrow \mathrm{HO}_{2} \quad k=2,1 \times 10^{7} \mathrm{~m}^{3} \mathrm{~mol}^{-1} \mathrm{~s}^{-1} \\
& 2 \mathrm{HO}_{2} \longrightarrow \mathrm{H}_{2} \mathrm{O}_{2}+\mathrm{O}_{2} \quad k=830 \mathrm{~m}^{3} \mathrm{~mol}^{-1} \mathrm{~s}^{-1} \\
& \mathrm{HO}_{2}+\mathrm{O}_{2}^{-} \longrightarrow \mathrm{H}_{2} \mathrm{O}_{2}+\mathrm{O}_{2}+\mathrm{OH}^{-} \quad k=9,7 \times 10^{4} \mathrm{~m}^{3} \mathrm{~mol}^{-1} \mathrm{~s}^{-1} \\
& \mathrm{H}^{*}+\mathrm{RH}_{2} \longrightarrow \mathrm{H}_{2}+\mathrm{RH}^{*} \quad \text { Se } k\left[\mathrm{RH}_{2}\right]>k\left[\mathrm{O}_{2}\right] \\
& \text { Adição pode ocorrer com } \\
& \text { soluto insaturado. } \\
& \mathrm{OH}^{*}+\mathrm{RH}_{2} \longrightarrow \mathrm{H}_{2} \mathrm{O}+\mathrm{RH}^{*} \quad \begin{array}{l}
\text { Adição pode ocorrer com } \\
\text { soluto insaturado. }
\end{array} \\
& 2 \mathrm{RH}^{*} \longrightarrow \mathrm{RH}-\mathrm{RH} \quad \text { Reticulação. } \\
& \longrightarrow \mathrm{RH}_{2}+\mathrm{R} \quad \begin{array}{l}
\text { Desproporcionamento } \\
\text { formando um produto }
\end{array} \\
& \text { insaturado. } \\
& \mathrm{RH}^{*}+\mathrm{O}_{2} \longrightarrow \mathrm{RHO}_{2}{ }^{*} \quad \text { Provável reação na presença } \\
& \text { de } \mathrm{O}_{2} \text {. } \\
& \text { Formação de produtos } \\
& \text { oxigenados estáveis. } \\
& \text { Formação de peróxido } \\
& \text { orgânico. } \\
& 2 \mathrm{RHO}_{2}{ }^{*}+\mathrm{HO}_{2}{ }^{*} \longrightarrow \mathrm{RH}-\mathrm{O}_{2} \mathrm{H}+\mathrm{O}_{2} \quad \begin{array}{l}
\text { Formação de hidroperóxido } \\
\text { orgânico. }
\end{array}
\end{aligned}
$$

FIGURA 3.4 - Mecanismo genérico de radiólise para solutos orgânicos em solução aquosa. 
Em geral, a reticulação e a cisão podem ocorrer simultaneamente em qualquer material irradiado, no entanto, normalmente uma tende a sobrepujar a outra e, assim, os polímeros podem ser amplamente colocados nas categorias de reticulação ou degradação (Spinks e Woods, 1990).

Durante o tempo de armazenamento, esses radicais podem ainda apresentar algumas reações resultando em alterações significativas das propriedades físicas do polímero irradiado e no aparecimento de efeitos que possam influenciar o desempenho do polímero (Montanaria et al., 1998).

\subsubsection{Efeito da radiação no PVP, PVA, PEG, glicerol, ágar, e KC PVP e PVA}

PVP é um polímero sintético, formado por múltiplas cadeias de vinilpirrolidonas, amorfo, solúvel em solventes hidrofílicos e hidrofóbicos que apresenta diversas aplicações, enquanto que o PVA é o único polímero sintético com grande número de grupos OH (Nijenhuis, 1997), que apresenta estrutura semicristalina e suas propriedades dependem, além de outros fatores, do grau de hidrólise.

Estudos conduzidos por Rosiak et al. (1995), referentes à reatividade das espécies formadas na radiólise da água com o PVP e o PVA, indicaram que a taxa de reação dos elétrons solvatados é relativamente baixa comparada à constante da taxa das reações de radicais hidroxila, podendo-se concluir que, entre as principais espécies da radiólise da água, as que reagem com os polímeros, são os radicais $\mathrm{OH}$. As estruturas dos macrorradicais formados e as frações estimadas provenientes da reação dos radicais hidroxila com PVP e PVA estão apresentadas nas FIGs. 3.5 e 3.6 (Rosiak et al., 1995).

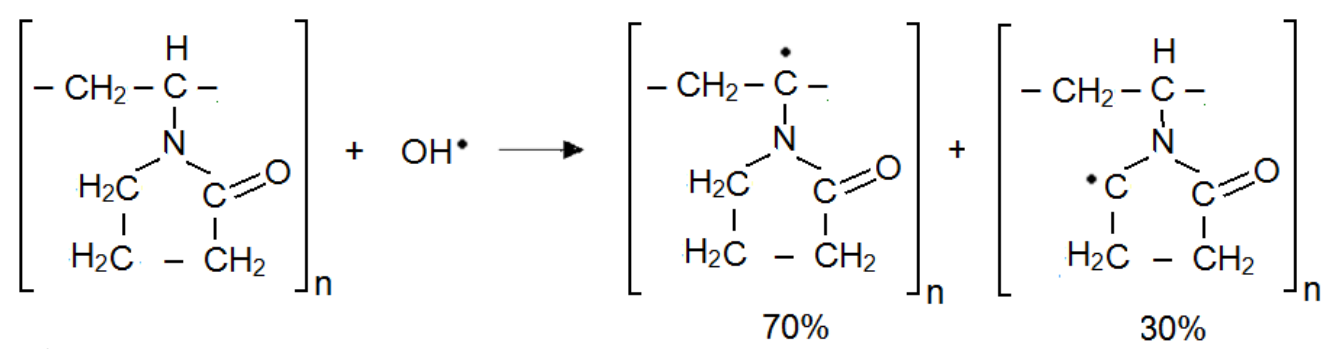

FIGURA 3.5 - Estrutura dos macrorradicais formados como resultado da abstração do hidrogênio do PVP pelos radicais hidroxila. 


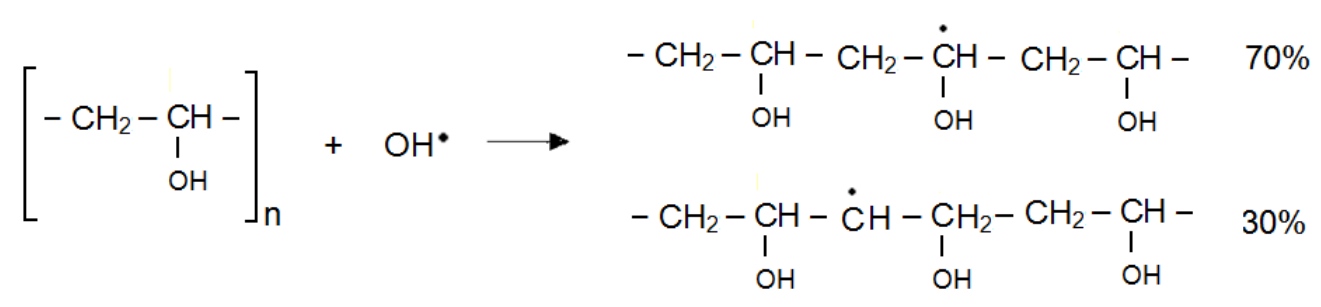

FIGURA 3.6 - Estrutura dos macrorradicais formados como resultado da abstração do hidrogênio do PVA, pelos radicais hidroxila.

\section{PEG e glicerol}

O polietilenoglicol (PEG) é um poliéter altamente solúvel em água e é aprovado pelo FDA para usos em drogas (parenterais, tópicos, supositórios, pulverizadores nasais), alimentos e cosméticos (Hinds e Kim, 2002).

As cadeias de PEG são atacadas aleatoriamente pelos radicais hidroxila, provenientes da radiólise da água e os radicais de hidrogênio na sua maior parte se combinam em pares formando gás hidrogênio (Merril et al., 1993). A estrutura do radical formado está apresentada na FIG. 3.7. A dose de radiação necessária para reticulação do PEG depende não só do peso molecular, mas também da concentração de PEG na solução (Graham, 1987).

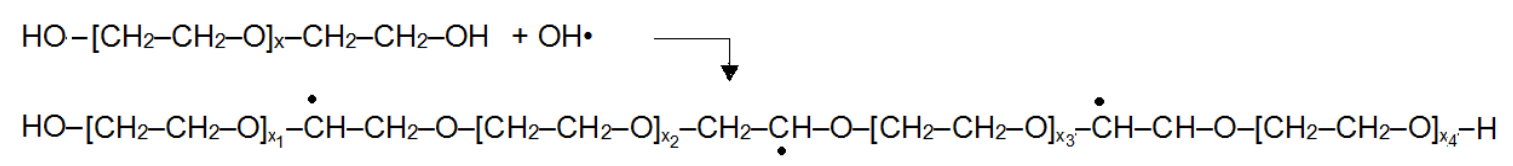

FIGURA 3.7 - Estrutura dos macrorradicais formados aleatoriamente, após irradiação do PEG, sob determinadas condições.

O propano-1,2,3-triol (glicerol) é um poliol com três grupos de hidroxilas, responsáveis por sua alta solubilidade em água e sua natureza higroscópica; é considerado um ótimo solvente e apresenta muitas aplicações entre as quais como ingrediente de produtos cosméticos, de higiene pessoal, formulações farmacêuticas e alimentícias (Pagliaro e Rossi, 2010). O fato de o glicerol ser uma molécula anfifílica possibilita a imobilização de princípios ativos lipossolúveis no hidrogel (Machado, 2010). A FIG. 3.8 apresenta a estrutura molecular do glicerol. 
<smiles>OCC(O)CO</smiles>

FIGURA 3.8 - Estrutura molecular do propano-1,2,3-triol.

O glicerol apresenta ação radioprotetora, que é atribuída à sua capacidade em capturar radicais OH (Reuvers et al., 1973). Sob ação da radiação os álcoois primários são oxidados gerando aldeídos enquanto que os álcoois secundários formam aldeídos e cetonas e os álcoois terciários geram cetonas (Spinks e Woods, 1964). O mecanismo de captura do radical $\mathrm{OH}$ pelo metanol, quando a água é o maior componente, pode ser representado pelas equações apresentadas na FIG. 3.9 (Philipp e Marsik, 1968).

$$
\begin{aligned}
\mathrm{CH}_{3}-\mathrm{OH}+2 \mathrm{OH}^{*} & \longrightarrow \mathrm{H}_{2} \mathrm{CO}+2 \mathrm{H}_{2} \mathrm{O} \\
\mathrm{H}_{2} \mathrm{CO}+2 \mathrm{OH}^{*} & \longrightarrow \mathrm{HCOOH}+\mathrm{H}_{2} \mathrm{O} \\
\mathrm{HCOOH}+2 \mathrm{H}^{*} & \longrightarrow \mathrm{CO}_{2}+2 \mathrm{H}_{2} \mathrm{O}
\end{aligned}
$$

FIGURA 3.9 - Reação de captura de radical $\mathrm{OH}^{*}$ pelo metanol.

\section{Ágar e kappa-carragena}

O ágar-ágar, também conhecido como ágar ou agarose, é extraído de diversos gêneros e espécies de algas marinhas vermelhas, da classe Rhodophyta, onde ocorre como carboidrato estrutural na parede das células. $\mathrm{O}$ ágar é uma mistura heterogênea de dois tipos de polissacarídeos: a agarose, fração gelificante e a agaropectina, fração não gelificante (Glicksman, 1969; Budavari, 1996).

As carragenas são polissacarídeos sulfatados, solúveis em água, extraídos de diversas espécies de algas marinhas vermelhas da classe Rhodophyceae (Alistair et al., 2006). Existem diferentes tipos de carragena, mas somente a kappa e a iota são capazes de formar géis termorreversíveis (Relleve et al., 1999).

Na FIG. 3.10 está apresentada a estrutura da agarose e da k-carragena, enquanto que a FIG. 3.11 ilustra o processo de gelificação da k-carragena formando hélices duplas que se agregam para formar uma rede tridimensional. 
A
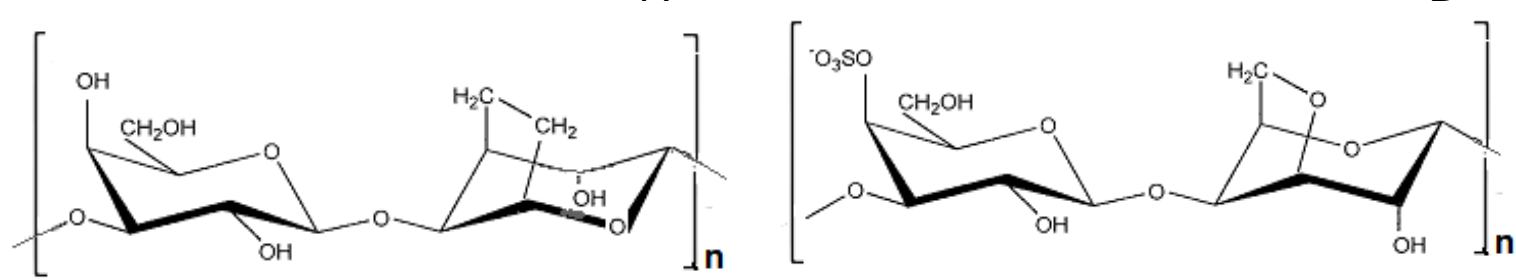

FIGURA 3.10 - Estrutura da (A) agarose: $\beta$-1,3 D-galactose e $\alpha$-1,4 3,6-anidro-Lgalactose e (B) K-carragena: $\beta$-D-galactose-4-sulfato-3,6-anidro- $\alpha$-D-galactose.

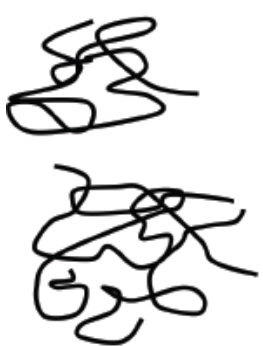

Forma randômica

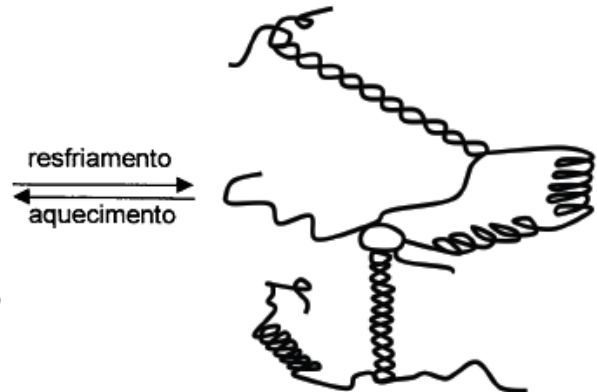

Hélices duplas
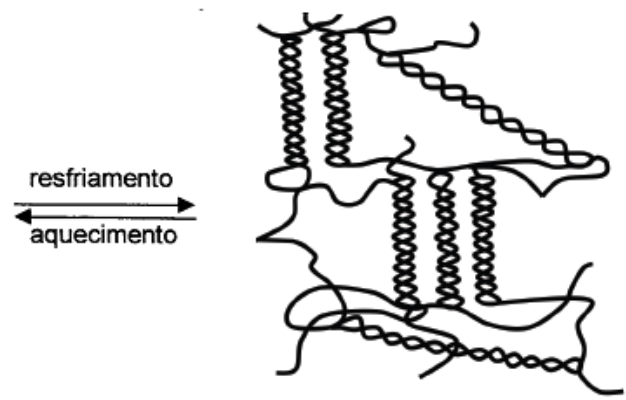

Hélices duplas agregadas

FIGURA 3.11 - Modelos de transição conformacional da k-carragena.

Fonte: Wu e IMAI, 2012. Traduzido pela autora.

Segundo Sintzel et al. (1997), os efeitos primários da irradiação dos polissacarídeos é a desidrogenação e decomposição, com liberação de hidrogênio gasoso, monóxido de carbono e dióxido de carbono. Em estudos realizados por Relleve et al. (2005), a irradiação da carragena em várias doses reduziu o grau de sulfonação e sugeriu que os grupos 4-O-sulfato e 2-O-sulfato são igualmente suscetíveis à clivagem radiolítica; além disso, a estrutura em hélice da k-carragena é conservada durante a degradação, apesar das mudanças estruturais. Para Urbain (1986), a mudança mais importante é a cisão das ligações glicosídicas gerando pequenas unidades de polissacarídeos.

\subsubsection{Esterilização por raios gama}

A dose necessária para esterilizar um produto é aproximadamente 5-30 kGy, de acordo com a carga microbiana inicial e a resposta dos agentes patogênicos à radiação (Sintzel et al., 1997), no entanto, para muitas legislações a dose de radiação para esterilização de dispositivos médicos ainda é 25 kGy; tal 
escolha foi feita em 1956 antes de generalização das Boas Práticas de Fabricação (Guyontard et al., 1988).

Duas teorias têm sido propostas para a ação letal da radiação ionizante sobre micro-organismos. A teoria da ação direta postula que a radiação induz a ionização do DNA do microorganismo enquanto que a teoria da ação indireta sugere que o primeiro passo envolve a formação de radicais livres, por exemplo, peróxidos ou outras moléculas no meio, induzindo reações secundárias no DNA do micro-organismo (Gopal, 1978).

\subsection{Prata}

Desde a antiguidade os gregos e romanos usavam a prata como bactericida e antibiótico, entretanto, desde 1897, quando alguns tipos de prata coloidal foram manufaturados sob o nome de "Collargol" este tem sido utilizado para applicações médicas (Boese, 1921). Entretanto, a prata coloidal só passou a despertar interesse nos pesquisadores depois do surgimento da resistência bacteriana a antibióticos e dos avanços da nanotecnologia (Nowack et al., 2011).

\subsubsection{Propriedades das NPAg}

De acordo com a teoria de Mie (1908), a interação da luz com os elétrons das pequenas partículas de metal resulta numa banda de absorção, cuja forma e intensidade dependem da constante dielétrica do complexo do metal, do tamanho do aglomerado e do ambiente (Henglein, 1993). As NPAg apresentam propriedades ópticas específicas, causadas pela excitação coletiva dos elétrons livres da partícula (Henglein, 1993), sendo possível obter espectro da banda plasmônica por espectroscopia de uv-visível.

Um estudo sistemático realizado por Mock et al. (2002) mostrou que a forma geométrica desempenha um papel importante na ressonância plasmônica e a FIG. 3.12 apresenta a relação encontrada para as NPAg preparadas por eles. 


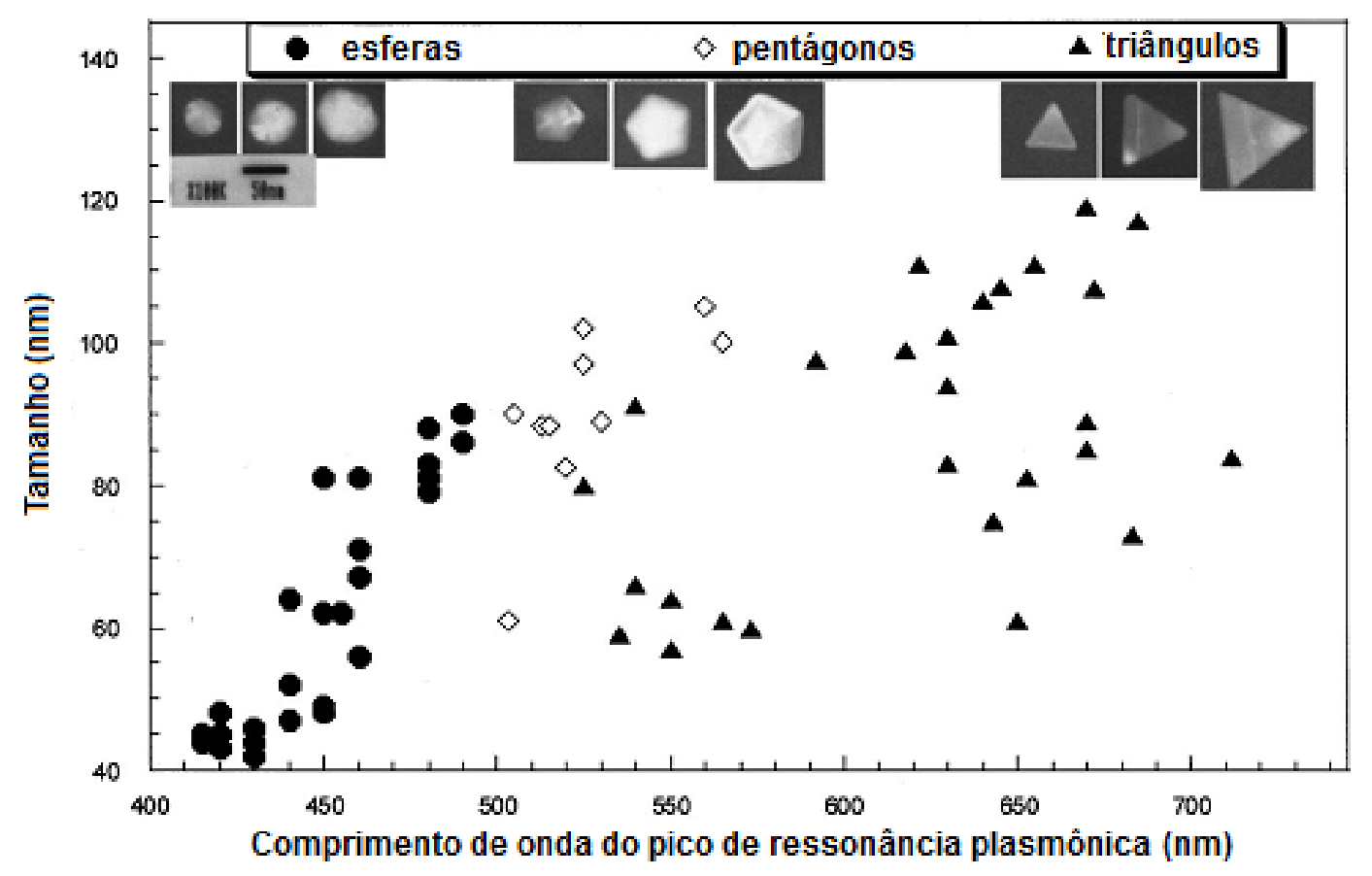

FIGURA 3.12 - Relação entre o tamanho e o comprimento de onda do pico espectral das NPAg e suas formas geometricas.

Fonte: Mock et al., 2002. Traduzido pela autora.

Pesquisas realizadas por Shin et al. (2004) mostraram que o tamanho médio das NPAg diminui com o aumento da quantidade de PVP na solução e o aumento da massa molecular do PVP aumenta o tamanho das nanopartículas.

\subsubsection{Síntese de NPAg por raios gama}

Os elétrons solvatados e os átomos de $\mathrm{H}$, gerados na radiólise da água, são fortes agentes redutores, podendo, sob determinadas condições, reduzir facilmente iões de prata levando-os ao estado de valência zero (Sheikh et al., 2009, Krkljes et al., 2007a) conforme apresentado na FIG. 3.13.

$$
\begin{aligned}
\mathrm{H}_{2} \mathrm{O} & \stackrel{\gamma}{\longrightarrow} \mathrm{e}_{\mathrm{aq},}^{-} \mathrm{H}^{*}, \mathrm{H}_{3} \mathrm{O}^{+}, \mathrm{OH}^{*}, \mathrm{H}_{2}, \mathrm{H}_{2} \mathrm{O}_{2}, \mathrm{HO}_{2}{ }^{\circ}, \ldots \\
\mathrm{Ag}^{+}+\mathrm{e}_{\mathrm{aq}}^{-} & \longrightarrow \mathrm{Ag}^{0} \\
\mathrm{Ag}^{+}+\mathrm{H}^{\cdot} & \longrightarrow \mathrm{Ag}^{0}+\mathrm{H}^{+}
\end{aligned}
$$

FIGURA 3.13 - Reação de redução do íon prata, pela ação da radiólise da água. 
No entanto, átomos de prata formados por irradiação tendem a formar oligómeros que crescem progressivamente formando aglomerados (FIG. 3.14).

$$
\begin{aligned}
& \mathrm{Ag}^{0}+\mathrm{Ag}^{+} \longrightarrow \mathrm{Ag}_{2}{ }_{2} \\
& \mathrm{Ag}_{\mathrm{n}-1}+\mathrm{Ag}^{+} \longrightarrow \mathrm{Ag}_{\mathrm{n}}{ }^{+}
\end{aligned}
$$

FIGURA 3.14 - Mecanismo de formação de aglomerado de prata.

A coalescência pode ser limitada por uma molécula polimérica agindo como estabilizador de aglomerado. Grupos funcionais com elevada afinidade com o metal podem garantir a fixação da molécula sobre a superfície do aglomerado enquanto a cadeia polimérica o protege limitando sua coalescência na fase inicial através da repulsão eletrostática ou do impedimento estérico (Belloni et al., 1998).

O PVP é um desses agentes protetores que controla o tamanho das partículas de prata e a distribuição de tamanho. A Fig. 3.15 apresenta o mecanismo de proteção do PVP, proposto por Zhang et al., (1996), na síntese de NPAg pela redução de nitrato de prata com hidrazina hidratada. O mesmo mecanismo, muito provavelmente, representa o mecanismo da ligação de coordenação das NPAg sintetizadas radioliticamente, conforme estudos efetuados por Jovanovic et al., (2012), no entanto presume-se que a principal forma de o PVP proteger NPAg no sistema sintetizado radioliticamente é através do nitrogênio do PVP coordenado com a prata (Jovanovic et al., 2012).
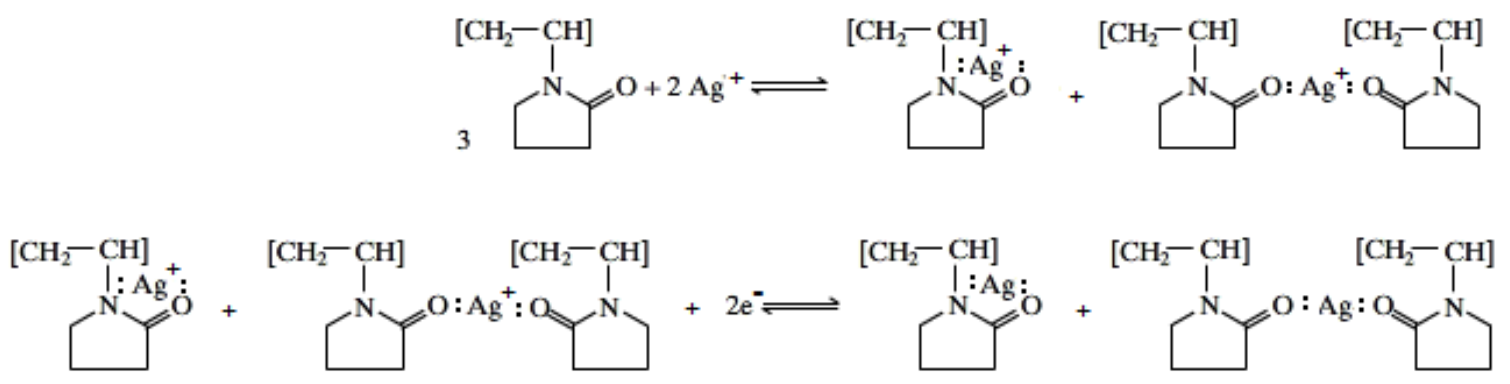

FIGURA 3.15 - Mecanismo da ligação de coordenação entre o PVP e as NPAg. Fonte: Zhang et. al., 1996.

O PVA também é um estabilizador eficiente para prevenir agregação da NPAg (Kumara et al., 2005, Krkljěs et al., 2007b), tendo em vista que a interação entre as nanopartículas de prata ocorre através dos grupos $\mathrm{OH}$ da molécula de 
PVA (Temgire e Joshi, 2004) e o oxigênio que poderia oxidar facilmente a prata é eliminado desaerando o meio.

\subsubsection{Ação biocida das NPAg e sua toxicidade em seres humanos}

Atualmente não há consenso sobre a citotoxicidade de NPAg, no entanto, a maioria das publicações mostra uma viabilidade celular reduzida e um aumento na geração de espécies reativas ao oxigênio após uma exposição a NPAg (Samberg et al., 2012). Estudos in vitro, realizados por diversos pesquisadores, demonstraram uma redução da função mitocondrial após a exposição de NPAg em células de neuroblastoma murino, células hepáticas, células estaminais de linha germinativa, carcinoma de células de pele humana, queratinócitos epidérmicos humanos e fibroblastos (Samberg et al. 2010). Entretanto, pequenas concentrações de prata não são tóxicas para as células humanas (Pal et al., 2007; Monteiro et al., 2009). Além disso, a liberação depende da natureza e da concentração do material antimicrobiano com prata, bem como da matriz do polímero (Monteiro et al., 2009).

Estudos conduzidos por Morones et al. (2005), que avaliaram o mecanismo da ação de NPAg sobre bactérias gram-negativas, mostraram que as NPAg, principalmente na gama de $1-10 \mathrm{~nm}$, se fixam na superfície da membrana da célula comprometendo seu bom funcionamento, como permeabilidade e respiração; as NPAg também são capazes de passar pela membrana e interagir com o enxofre e o fósforo de compostos do DNA. Além disso, as NPAg liberam ions $\mathrm{Ag}^{+}$, que representam uma contribuição adicional para o efeito bactericida. 


\section{METODOLOGIA}

\subsection{Materiais}

As misturas foram preparadas com PVP K90 (Plasdone® $\mathrm{K}-90 \mathrm{D}, \overline{M_{w}}=$ ca. 1.300 .000 g.mol ${ }^{-1}$, viscosidade aparente ca.55 mPa.s, em sol. aquosa $5 \%$ / $25^{\circ} \mathrm{C}$, proveniente da ISP), PVA (Vinarol STH, $\overline{M_{w}}=$ ca. $205.000 \mathrm{~g} \cdot \mathrm{mol}^{-1}$, viscosidade aparente ca. $40 \mathrm{mPa}$.s, sol. aquosa $4 \% / 20^{\circ} \mathrm{C}$, grau de hidrólise ca. 88\%, proveniente da Clariant), PEG 300 e glicerol (provenientes da Oxiteno), polissacarídeo natural ágar-ágar (Ágar n 1 - LP001, proveniente da Oxoid), kappa-carragena (KC, proveniente da Agargel), nitrato de prata (grau P.A., proveniente da Cennabras) e água de osmose reversa.

\subsection{Planejamento de Misturas}

A composição das misturas e a análise dos resultados foram obtidas a partir do software Design-Expert®, versão 8.0.7.1 Trial, utilizando D-Optimal design. Os limites superiores e inferiores de cada um dos componentes utilizados, para cada sistema estudado, estão apresentados na TAB. 4.1 tendo como origem resultados provenientes de estudos preliminares. 
TABELA 4.1 - Limites dos componentes das misturas para síntese dos hidrogéis.

\begin{tabular}{clcc}
\hline \multirow{2}{*}{ Sistemas } & \multirow{2}{*}{ Materiais } & \multicolumn{2}{c}{ Limites $-\mathbf{w} / \mathbf{w}$ (\%) } \\
& & Inferior & Superior \\
\hline \multirow{4}{*}{1} & PVP & 4 & 20 \\
& PEG & 0 & 5 \\
& Ágar & 0 & 1,5 \\
& Água & 73,5 & 96 \\
\hline \multirow{4}{*}{2} & PVP & 4 & 20 \\
& Glicerol & 0 & 5 \\
& Ágar & 0 & 1,5 \\
& Água & 73,5 & 96 \\
\hline \multirow{4}{*}{3} & PVA & 4 & 14 \\
& KC & 0 & 1,0 \\
& Ágar & 0 & 1,0 \\
& Água & 84 & 96 \\
\hline
\end{tabular}

\subsection{Preparação dos hidrogéis}

\subsubsection{Hidrogéis sem prata}

Os hidrogéis sintetizados para a análise estatística foram preparados utilizando as composições apresentadas na TAB. 4.2 onde se observam 5 réplicas (16 a 20), para avaliar o erro das estimativas dos efeitos e obter informações relacionadas à variância do processo. 
T ABELA 4.2 - Composições sugeridas pelo software Design-Expert® para preparação das misturas para síntese dos hidrogéis.

\begin{tabular}{|c|c|c|c|c|c|c|c|c|c|c|c|c|}
\hline \multirow{2}{*}{$\begin{array}{c}\text { Hidrogéis } \\
\text { Ordem } \\
\text { padrão }\end{array}$} & \multicolumn{4}{|c|}{$\begin{array}{c}\text { Sistema } 1 \\
\text { Componentes - w/w (\%) }\end{array}$} & \multicolumn{4}{|c|}{$\begin{array}{c}\text { Sistema } 2 \\
\text { Componentes - w/w }(\%)\end{array}$} & \multicolumn{4}{|c|}{$\begin{array}{c}\text { Sistema } 3 \\
\text { Componentes - w/w (\%) }\end{array}$} \\
\hline & PVP & PEG & ágar & $\mathrm{H}_{2} \mathrm{O}$ & PVP & glicerol & ágar & $\mathrm{H}_{2} \mathrm{O}$ & PVA & $\mathrm{KC}$ & ágar & $\mathrm{H}_{2} \mathrm{O}$ \\
\hline 2 & 20,00 & 5,00 & 1,50 & 73,50 & 20,00 & 5,00 & 1,50 & 73,50 & 14,00 & 1,00 & 1,00 & 84,00 \\
\hline 3 & 20,00 & 5,00 & 0,00 & 75,00 & 20,00 & 5,00 & 0,00 & 75,00 & 14,00 & 1,00 & 0,00 & 85,00 \\
\hline 4 & 12,00 & 5,00 & 0,75 & 82,25 & 12,00 & 5,00 & 0,75 & 82,25 & 9,00 & 1,00 & 0,50 & 89,50 \\
\hline 6 & 20,00 & 2,50 & 0,75 & 76,75 & 20,00 & 2,50 & 0,75 & 76,75 & 14,00 & 0,50 & 0,50 & 85,00 \\
\hline 7 & 20,00 & 0,00 & 1,50 & 78,50 & 20,00 & 0,00 & 1,50 & 78,50 & 14,00 & 0,00 & 1,00 & 85,00 \\
\hline 8 & 4,00 & 0,00 & 1,50 & 94,50 & 4,00 & 0,00 & 1,50 & 94,50 & 4,00 & 0,00 & 1,00 & 95,00 \\
\hline 9 & 20,00 & 0,00 & 0,00 & 80,00 & 20,00 & 0,00 & 0,00 & 80,00 & 14,00 & 0,00 & 0,00 & 86,00 \\
\hline 10 & 4,00 & 2,50 & 0,00 & 93,50 & 4,00 & 2,50 & 0,00 & 93,50 & 4,00 & 0,50 & 0,00 & 95,50 \\
\hline 15 & 16,00 & 1,25 & 0,39 & 82,36 & 16,00 & 1,25 & 0,39 & 82,36 & 14,00 & 0,25 & 0,25 & 85,50 \\
\hline 16 & 20,00 & 0,00 & 1,50 & 78,50 & 20,00 & 0,00 & 1,50 & 78,50 & 14,00 & 0,00 & 1,00 & 85,00 \\
\hline 17 & 4,00 & 0,00 & 1,50 & 94,50 & 4,00 & 0,00 & 1,50 & 94,50 & 4,00 & 0,00 & 1,00 & 95,00 \\
\hline 18 & 20,00 & 5,00 & 0,00 & 75,00 & 20,00 & 5,00 & 0,00 & 75,00 & 14,00 & 1,00 & 0,00 & 85,00 \\
\hline 19 & 20,00 & 5,00 & 1,50 & 73,50 & 20,00 & 5,00 & 1,50 & 73,50 & 14,00 & 1,00 & 1,00 & 84,00 \\
\hline 20 & 12,00 & 2,50 & 1,50 & 84,00 & 12,00 & 2,50 & 1,50 & 84,00 & 9,00 & 0,50 & 1,00 & 89,50 \\
\hline
\end{tabular}


Após solubilização e homogeneização dos componentes, foi borbulhado nitrogênio e, posteriormente, as amostras foram submetidas a vácuo para remoção das bolhas, conforme apresentado na FIG. 4.1 A - E.

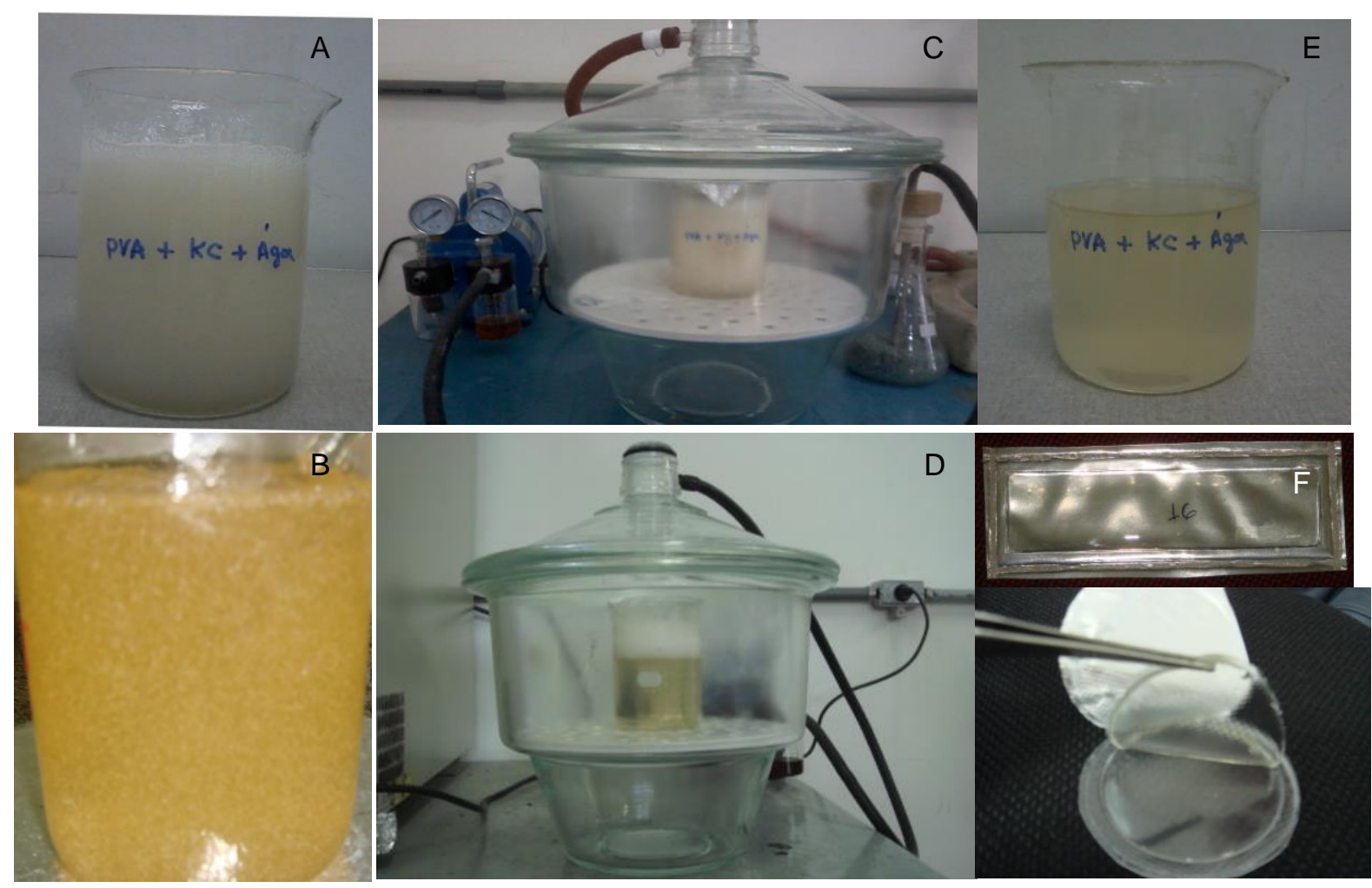

FIGURA 4.1 - Preparação dos hidrogéis: (A) mistura de baixa viscosidade, após borbulhamento de $\mathrm{N}_{2}$, (B) mistura de alta viscosidade, após várias horas mantida sob aquecimento, durante processo de remoção das bolhas, (C e D) dessecador com amostra sendo submetida a vácuo, (E) amostra apresentada em $A$, após completa remoção do $N_{2}$, (F) corpos de prova com hidrogel reticulado.

Em seguida as soluções foram embaladas, por casting, em recipientes termoformados; seladas e reticuladas em irradiador de Cobalto-60, do tipo gammacell 220, FIG. 4.2 onde foram irradiadas com raios gama provenientes de uma fonte de ${ }^{60} \mathrm{Co}$, com dose de $25 \mathrm{kGy}$. A taxa de dose variou de $1,98 \mathrm{kGy} \cdot \mathrm{h}^{-1}$ a $1,58 \mathrm{kGy} \cdot \mathrm{h}^{-1}$, em função da variação da meia-vida da fonte. 

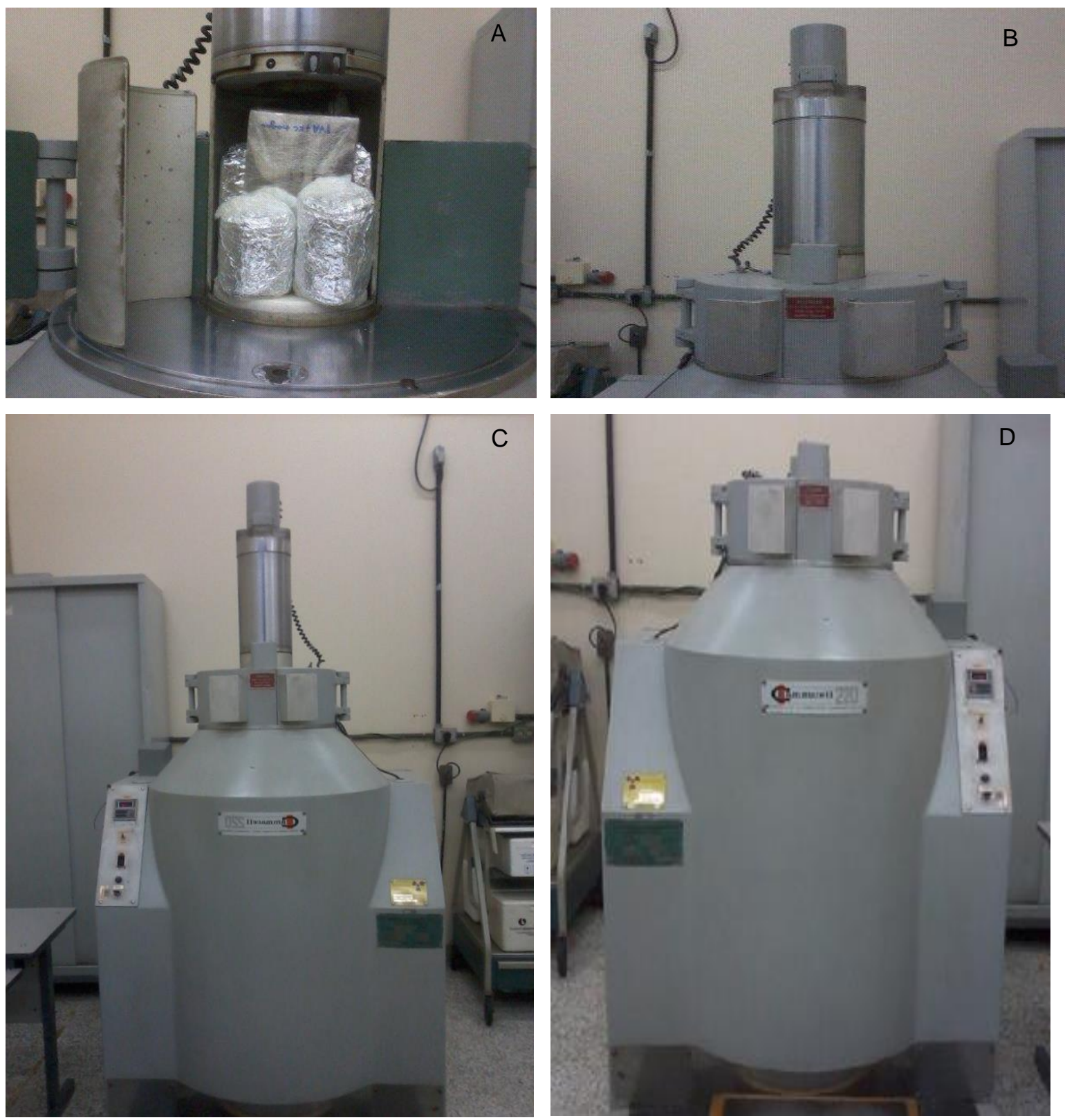

FIGURA 4.2 - Irradiador de Cobalto-60 do tipo gammacell 220. (A) câmara de irradiação com amostras de hidrogel com prata, (B) câmara de irradiação porta amostra secundária - antes de ser exposta à câmara secundária, (C) vista frontal do irradiador com câmara secundária exposta. (D) vista frontal do irradiador, com câmara de irradiação envolta na câmara primária - que contém as pastilhas de Co-60 - no interior do irradiador.

\subsubsection{Hidrogéis com NPAg}

A síntese dos hidrogéis com nanoparticulas de prata (NPAg) foi realizada de acordo com o item 4.3.1, porém foi acrescentado nitrato de prata. 
Os hidrogéis à base de PVP foram preparados com 40 ppm de prata enquanto que o hidrogel à base de PVA com 60 ppm. Devido à fotossensibilidade do nitrato de prata, a preparação foi realizada no escuro, assim como o acondicionamento das amostras. Os hidrogéis com prata foram irradiados sob as mesmas condições que as misturas sem nitrato de prata.

\subsection{Caracterização}

\subsubsection{Ajuste das formulações}

Amostras com cerca de $2 \mathrm{~g}$ foram pesadas em balança analítica, levadas à estufa a $60^{\circ} \mathrm{C}$ até peso constante e posteriormente calculado o teor de sólidos, conforme eq. 4.1.

$$
\text { Teor de sólidos }=\frac{\mathrm{M}_{\mathrm{f}}}{\mathrm{M}_{\mathrm{o}}}
$$

Sendo: $M_{o}$ é a massa da amostra antes da secagem e $M_{f}$ é a massa da amostra seca.

O percentual final de cada um dos componentes das misturas, com exceção da água, foi calculado de acordo com a eq. 4.2 e o teor de água calculado conforme eq. 4.3.

Componente ajustado $(\%)=\%$ inicial do componente $\mathrm{x}$ teor de sólidos

Teor de água $(\%)=100$ - soma dos demais componentes ajustados

\subsubsection{Fração gel}

Amostras com ca. $2 \mathrm{~g}$ foram desidratadas em estufa a $60^{\circ} \mathrm{C}$ até peso constante, embaladas em bolsas de aço inoxidável com tela de 300 meshes, estas imersas em $1000 \mathrm{ml}$ de água destilada e levadas a autoclave a $120^{\circ} \mathrm{C}$ por 2 h. Posteriormente as amostras foram novamente secas, pesadas, e a fração gel foi calculada de acordo com a Eq. 4.4. O resultado final foi obtido a partir da média de 5 amostras de cada membrana sintetizada. 


$$
\text { Fração gel }(\%)=\frac{M_{f}}{M_{o}} x 100
$$

Sendo: $M_{f}$ é a massa da amostra seca após extração da fração solúvel e $M_{o}$ é a massa da amostra seca antes da extração.

\subsubsection{Intumescimento}

O grau de intumescimento dos hidrogéis sintetizados foi determinado pelo aumento de massa das membranas, conforme ASTM D570. Os ensaios foram realizados em quintuplicata, utilizando amostras com ca. $2 \mathrm{~g}$ e medindo ca. 24 $\mathrm{mm} \times 20 \mathrm{~mm} \times 2 \mathrm{~mm}$. As amostras foram imersas em $100 \mathrm{ml}$ de água de osmose reversa, onde foram mantidas a $30{ }^{\circ} \mathrm{C}$. Após períodos de tempo regulares as amostras foram retiradas e secas suavemente em papel filtro, pesadas e retornadas à água. O processo foi repetido até estabilização do peso, observado perda de massa, desintegração ou colapso da amostra, conforme ilustrado na FIG. 4.3.
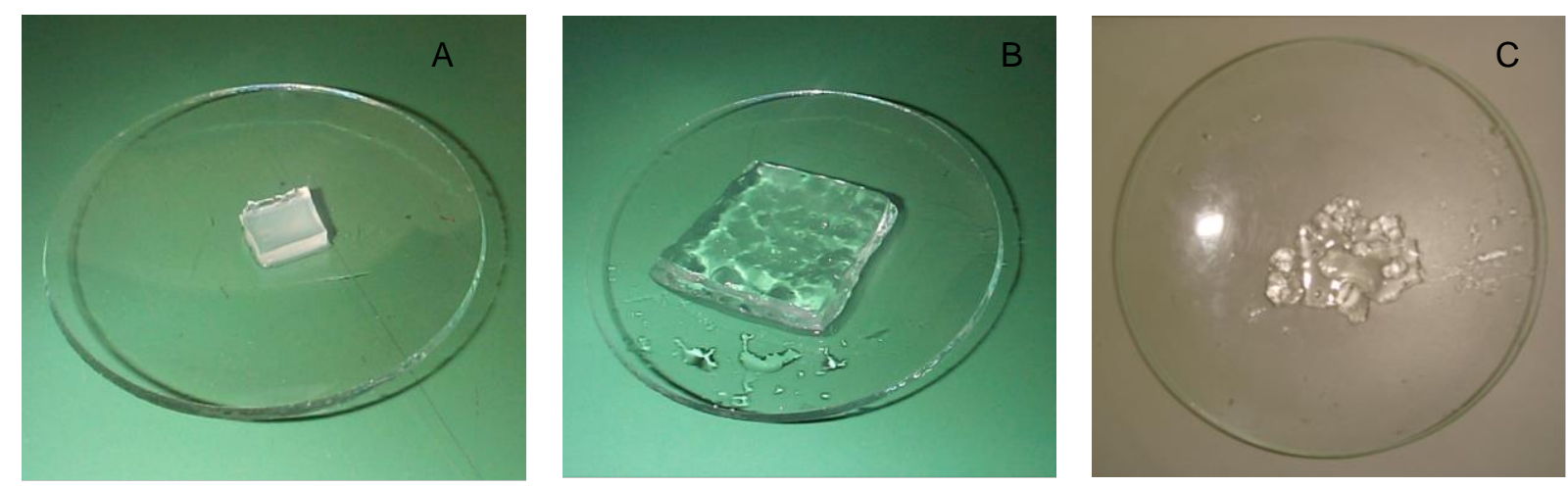

FIGURA 4.3 - Amostras de hidrogéis.(A) antes do intumescimento, (B) após estabilização do peso, (C) desintegrada ou colapsada.

Os resultados de intumescimento para cada medida efetuada foram calculados de acordo com a Eq. 4.5.

$$
\text { Intumescimento }(\%)=\frac{M_{i}-M_{s}}{M_{s}} \times 100
$$

Sendo: $M_{i}$ é a massa do hidrogel intumescido e $M_{s}$ é a massa da amostra do hidrogel seco antes da imersão em água. 
Os valores médios foram calculados conforme eq. 4.5 e em seguida colocados em gráfico de intumescimento $x$ tempo, e a seguir, traçada a curva de tendência e o valor obtido para o intumescimento no equilíbrio foi obtido diretamente no gráfico.

\subsubsection{Propriedades mecânicas}

Os ensaios de propriedades mecânicas foram realizados em texturômetro, marca Stable Micro Systems, modelo TA.X Plus, utilizando corpos de prova preparados em moldes termoformados, onde foram reticulados nas dimensões estabelecidas. Após a irradiação aguardaram-se o prazo de pelo menos 15 dias para realização dos ensaios e as amostras foram climatizadas por pelo menos 7 dias a aproximadamente $18^{\circ} \mathrm{C}$, temperatura na qual os testes foram realizados.

\subsubsection{Ensaios de tração: tensão, deformação e módulo elástico}

Os ensaios de tração foram realizados conforme norma ASTM D 882-95, utilizando corpos de prova medindo $100 \mathrm{~mm} \times 24 \mathrm{~mm} \times 2,5 \mathrm{~mm}$. A velocidade de tração foi de 8,33 mm.s ${ }^{-1}$, com exceção dos hidrogéis $3,9,10,11,12$, e 18 de PVP/PEG/ágar e PVP/glicerol/ágar cuja velocidade de tração foi de 0,833 mm.s ${ }^{-1}$, tendo em vista que os mesmos apresentaram resistência muito baixa e dificuldade até mesmo para tirá-los dos moldes e prendê-los no equipamento. Foram utilizados pelo menos 5 corpos de prova de cada amostra

Os dados de tensão foram calculados pelo equipamento a partir dos dados de área da sessão transversal fornecidso para cada amostra medida e os resultados de tensão e deformação foram lidos diretamente no gráfico tensão $x$ deformação, no ponto de ruptura.

O módulo elástico foi calculado de acordo com a eq. 4.6 a partir da média dos resultados obtidos no trecho reto de cada uma das curvas do diagrama tensão x deformação, usando a Lei de Hooke (Eq. 4.6)

$$
\begin{aligned}
& \sigma=E \cdot \varepsilon \\
& E=\frac{\sigma}{\varepsilon}
\end{aligned}
$$

$$
\text { sendo } \varepsilon=\frac{\Delta L}{L_{o}}
$$

Sendo: $\sigma$ é a tensão, $\varepsilon$ é a deformação, $E$ é o modulo elástico, $\Delta L$ é a variação do comprimento e $L_{o}=0,06 \mathrm{~m}$ 


\subsubsection{Ensaio de perfuração: força puntiforme e deformação}

Os ensaios de perfuração foram realizados conforme Gontard et al. (1993) e Sobral et al. (2001), segundo esquema apresentado na FIG. 4.4, utilizando corpos de prova circulares com $30 \mathrm{~mm}$ de diâmetro e ca. 1,5 mm de espessura, reticulados em embalagens termoformadas e seladas. Os corpos de prova foram fixados em suporte com cavidade cilíndrica, e foi utilizada uma sonda ("probe") de aço inoxidável com ponta esférica de 7,9 mm de diâmetro.

A força puntiforme $\left(F_{p}\right)$ foi obtida nos gráficos de força $x$ deformação, sendo que os pontos da deformação foram calculados conforme Eq. 4.8, considerando que a tensão está perfeitamente distribuída em toda a superfície do corpo de prova. (Sobral et al., 2001).

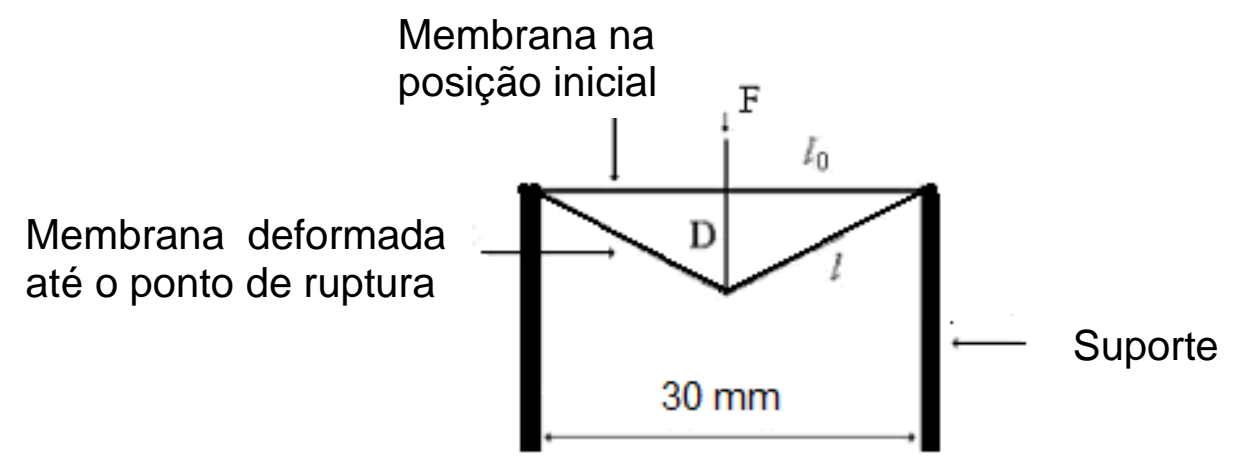

FIGURA 4.4 - Diagrama de Sobral et al. (2001), modificado e traduzido pela autora.

$$
\text { Deformação }=\frac{\Delta l}{l_{o}} x 100=\frac{\sqrt{D^{2}+l_{o}^{2}}-l_{o}}{l_{o}} x 100(\%)
$$

Sendo: $I_{0}$ é o comprimento inicial do corpo de prova (raio da amostra $=15 \mathrm{~mm}$ ) e $\mathrm{D}$ é o deslocamento do probe na perfuração.

\subsection{Análise estatística}

Os resultados obtidos nos experimentos laboratoriais foram analisados pelo software Design-Expert@ versão 8.0.7.1 Trial, a um nível de confiabilidade de $90 \%$. 


\subsection{Otimização das formulações}

As formulações otimizadas foram geradas pelo software Design Expert円. A otimização foi obtida a partir da intersecção das superfícies de resposta das propriedades almejadas. Foram consideradas todas as propriedades estudadas, e as restrições foram definidas em função de uma resposta compatível.

Somente para o sistema PVA/KC/ágar foi obtida mais de uma formulação otimizada e a escolha foi efetuada aleatoriamente, tendo em vista que as composições e os resultados previstos eram muito próximos.

\subsection{Espectroscopia na região do ultravioleta-visível}

Análises de espectrofotometria de UV-visível foram efetuadas através de espectro de absorção na faixa de comprimentos de onda $(\lambda)$ de 300 a $800 \mathrm{~nm}$, em espectrofotômetro Varian Cary 50. Os espectros foram obtidos a partir de membranas de hidrogel reticuladas com espessura de $1,5 \mathrm{~mm}$, posicionadas diretamente no porta-amostra.

\subsection{Microscopia Eletrônica de Varredura}

\section{SEM - EDS}

A morfologia da fratura dos hidrogéis otimizados foi investigada em microscópio eletrônico de varredura tabletop Hitachi TM 7000. Para tal, as análises foram realizadas após fratura criogênica, com $\mathrm{CO}_{2}$ líquido, e posterior liofilização dos hidrogéis, em liofilizador de bancada Terroni ${ }^{\circledR}$, linha Enterprise.

Com um sistema de EDS (Espectrômetro de raios-X por dispersão de energia) Bruker Quantax 70 acoplado, foi possível determinar o mapa químico que representa a distribuição das NPAg na superfície e na fratura dos hidrogéis. Neste caso as amostras analisadas foram previamente secas em estufa a $60^{\circ} \mathrm{C}$ por 24h.

\section{SEM - FEG}

Por meio de microscopia eletrônica de varredura de efeito de campo (SEMFEG) é possível ampliações de alta resolução com feixe de elétrons de menor energia que no microscópio sem dispositivo de emissão de campo. Os hidrogéis com NPAg foram observados em SEM-FEG marca PHILIPS $\AA^{8}$, modelo XL30, com 
o objetivo de visualizar a distribuição das NPAg na superfície dos hidrogéis, bem como a morfologia das mesmas, sem que as amostras de hidrogel se degradassem. Para realização das análises os hidrogéis foram secos em estufa a $60^{\circ} \mathrm{C}$ por $24 \mathrm{~h}$ e posteriormente recobertos com ouro.

\subsection{Atividade antimicrobiana}

\subsubsection{Teste de disco-difusão em ágar}

O teste de disco-difusão em ágar, também conhecido como Método KirbyBauer foi realizado com as bactérias $P$. aeruginosa (gram-negativa) ATCC 25923 e S. aureus (gram-positiva) ATCC 27853, conforme padrão estabelecido pelo NCCLS e pela ANVISA (Agência Nacional de Vigilância Sanitária, 2008).

Primeiramente as colônias foram suspensas em meio nutritivo (MuellerHinton Broth) numa concentração de 0,5 da escala Mac Farland ( $\left.1 \times 10^{8} \mathrm{UFC} / \mathrm{mL}\right)$ e em seguida foi efetuada a semeadura em todas as direções em placas de Petri com ágar Mueller-Hinton, utilizando um suabe estéril. Posteriormente, membranas dos hidrogéis com prata e sem prata (controle negativo), com ca. $5 \mathrm{~mm}$ de diâmetro e 2,5 mm de espessura, foram colocadas sobre a superfície do meio inoculado, assim como discos do antibiótico ciprofloxacina (controle positivo). As placas foram incubadas em estufa bacteriológica a $36^{\circ} \mathrm{C}$ por $18 \mathrm{~h}$ e então comparadas entre si.

\subsubsection{Método de diluição em caldo}

Colônias individuais das cepas de S. aureus (ATCC 27853) e P. aeruginosa (ATCC 25923) foram suspensas em meio nutritivo (Mueller-Hinton Broth) e deixadas crescer por $2 \mathrm{~h}$; posteriormente foi efetuada a lavagem das bactérias e as mesmas foram diluídas em tampão isotônico de glicose/fosfato - IGP 1mM, até concentração de $1 \times 10^{5} \mathrm{UFC} / \mathrm{mL}$, com o objetivo de mantê-las vivas sem que se replicassem. Em seguida, $0,06 \mathrm{~mL}$ da suspensão de cada uma das bactérias foi colocado sobre cada uma das amostras de hidrogel, com ca. $5 \mathrm{~mm}$ de diâmetro e 2,5 mm de espessura, sendo então totalmente absorvido pelas mesmas conforme FIG. 4.5 A. Posteriormente as membranas intumescidas foram mergulhadas em "eppendorf" com $1 \mathrm{~mL}$ de meio nutritivo, conforme FIG. 4.5 B, efetuada a diluição seriada onde $0,1 \mathrm{~mL}$ de cada diluição foi espalhada em placas contendo ágar 
Mueller-Hinton, com auxílio de alça de drigalsky, e estas incubadas por 24 h a 37 ${ }^{\circ} \mathrm{C}$, na presença de $\mathrm{O}_{2}$ para controle da contagem de colônias.
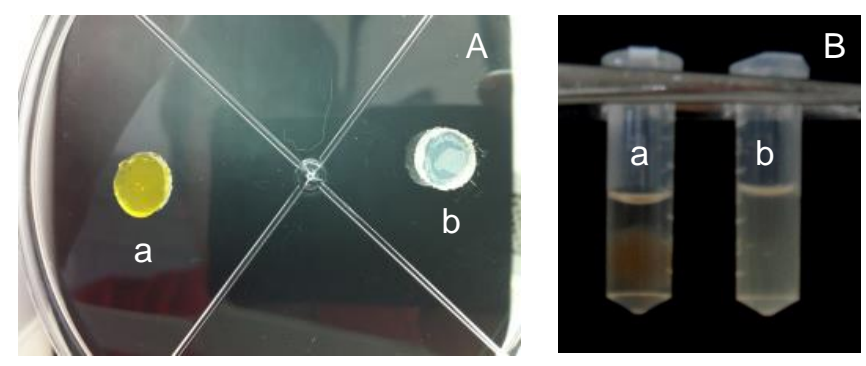

FIG. 4.5 - Amostras de hidrogéis (A) com e sem prata, com P. aeruginosa, (B) amostras anteriores, mergulhadas no meio nutritivo, sendo (a) amostra testada e (b) controle positivo - hidrogel sem prata.

Para confirmar a morte das bactérias, após 24 h novas alíquotas de 0,01 $\mathrm{mL}$ de cada uma das amostras foram colhidas, efetuadas diluições de 1:100, semeadas sobre placas de petri contendo ágar Mueller-Hinton e estas incubadas por $24 \mathrm{~h}$ a $37^{\circ} \mathrm{C}$, na presença de $\mathrm{O}_{2}$.

\subsection{Citotoxicidade in vitro}

A avaliação da citotoxicidade in vitro de hidrogéis foi realizada com extratos dos mesmos, diluídos em série, preparados de acordo com a norma ISO 10993-5 e células de fibroblastos humanos, linha de células permanentes linhagem $\mathrm{HaCaT}$ (CLS no. 300493), de acordo com o método de captura do vermelho neutro, seguindo trabalhos publicados (Finter, 1969; Hansen et al, 1989; Ciapetti,1996, Rogero et al., 2003 e Lincopan, 2005).

As células de fibroblastos foram cultivadas em monocamada, em garrafas contendo $250 \mathrm{~mL}$ de meio mínimo de Eagle (MEM - Minimum Essential Medium), $20 \mathrm{mM}$ de glutamina, $10 \%$ de soro fetal bovino, penicilina $(100 \mathrm{Ul} / \mathrm{mL})$ e estreptomicina $(100 \mu \mathrm{g} / \mathrm{mL})$, e mantidas a $37^{\circ} \mathrm{C}$ em atmosfera com $5 \% \mathrm{CO}_{2}$. Após $24 \mathrm{~h}$ de cultura, na fase de pré-confluência, as células foram colhidas com tripsina, contadas em câmara de Neubauer e distribuídas em microplacas de 96 poços, sendo $200 \mu \mathrm{L} /$ poço, numa concentração final de ca. $1 \times 10^{5}$ células $/ \mathrm{mL}$. Posteriormente as microplacas foram mantidas em estufa por $24 \mathrm{~h}$.

A extração dos hidrogéis foi efetuada em estufa, durante $24 \mathrm{~h}$ a $37^{\circ} \mathrm{C}$ e obtida a partir da imersão de cada uma das triplicatas em $1 \mathrm{~mL}$ de MEM para cada $1 \mathrm{~cm}^{2}$ de amostra. Como controle positivo foi utilizado $0,1 \%$ triton X100 em D- 
glicose (100\% de citotoxicidade) e como controle negativo D glicose estéril $5 \%$ ( $100 \%$ de viabilidade) que também foram mantidos em estufa por $24 \mathrm{~h}$ a $37^{\circ} \mathrm{C}$. Os extratos das amostras e os controles positivo e negativo foram diluídos com MEM até concentrações de $6,25 \%, 12,5 \%, 25 \%, 50 \%$ e $100 \%$.

Após $24 \mathrm{~h}$ de incubação das microplacas, o meio de cultura foi aspirado desde a monocamada, lavado duas vezes com PBS e substituído pelos extratos obtidos, assim como pelos controles positivo e negativo. As microplacas contendo os extratos e controles foram novamente incubadas por uma hora a $37^{\circ} \mathrm{C}$ em atmosfera úmida e $5 \%$ de $\mathrm{CO}_{2}$.

Todas as amostras e controles foram testados em triplicata e os ensaios foram realizados em capela de fluxo laminar utilizando técnicas assépticas e material estéril.

A viabilidade celular foi determinada pelo método colorimétrico no qual a captura do vermelho neutro é proporcional à viabilidade. Assim, após $1 \mathrm{~h}$ de interação, os diferentes meios foram aspirados desde as monocamadas, os poços lavados com PBS, e preenchidos com $200 \mu \mathrm{L}$ de uma solução de corante vermelho neutro $(67 \mu \mathrm{g} / \mathrm{mL}$ de D-glicose $5 \%$ estéril, previamente filtrada através de filtro Milipore estéril de $0,45 \mu$ ). As placas contendo as células com o corante foram incubadas adicionalmente por $2 \mathrm{~h}$ a $37^{\circ} \mathrm{C}$, em estufa de cultura celular, para incorporação do corante nas células e posteriormente o corante foi descartado. As células foram novamente lavadas com PBS, duas vezes, e finalmente o corante absorvido pelas células foi extraído pela adição de $0,1 \mathrm{~mL}$ de etanol $50 \%(\mathrm{v} / \mathrm{v})$ em ácido acético (1\%), usando agitador rotacional durante 10 minutos. Então a absorbância $(A)$ do corante extraído foi lida em espectrofotômetro, leitor de ELISA, em $540 \mathrm{~nm}$.

O potencial tóxico (índice de citotoxicidade) para cada uma das diluições avaliadas foi determinado de acordo com as Eqs. 4.9 e 4.10.

$$
\text { Viabilidade celular (\%) }=\frac{\mathrm{A}_{540} \text { células tratadas }}{\mathrm{A}_{540} \mathrm{CN}} \times 100
$$

Sendo: $A_{540}$ é a absorbância, em $\lambda=540 \mathrm{~nm}$, do corante extraído das células tratadas com o extrato e das células não tratadas (controle negativo - CN).

$$
\text { Índice de citotoxicidade }(\%)=100-\text { viabilidade celular }
$$




\section{$5 \quad$ RESULTADOS E DISCUSSÕES}

\subsection{Preparação dos hidrogéis}

$\mathrm{O}$ borbulhamento de $\mathrm{N}_{2}$ nas soluções preparadas para remoção do $\mathrm{O}_{2}$ e o uso de vácuo para remoção das bolhas formadas, ambos a quente e em sistemas abertos, ocasionaram perda de água do meio, sem que esta pudesse ser compensada, alterando a composição das soluções previamente planejadas.

Para o sistema PVP/PEG/ágar a perda de água dos hidrogéis obtidos variou entre $0,75 \%$ e $11,39 \%$. Os hidrogéis do sistema PVP/glicerol/ágar tiveram perda de água de $0,30 \%$ a $14,33 \%$ e para as misturas de PVA/KC/ágar a perda de água variou entre $0,52 \%$ e 8,29\%. Para minimizar erros na análise estatística, foi efetuada análise do teor de sólidos para cada um dos hidrogéis obtidos e efetuado o ajuste das formulações inicialmente propostas. A composição final dos hidrogéis preparados está apresentada na TAB. 5.1. Apesar de esses resultados terem indicado pequenas variações nas composições finais, essas variações foram consideradas para evitar a inserção de erros na análise estatística.

Por outro lado, observou-se grande variação de viscosidade e consequentemente do tempo para remoção das bolhas, acarretando um forte amarelamento das amostras mais viscosas. 
TABELA 5.1 - Composição final, após ajuste, dos hidrogéis preparados e irradiados.

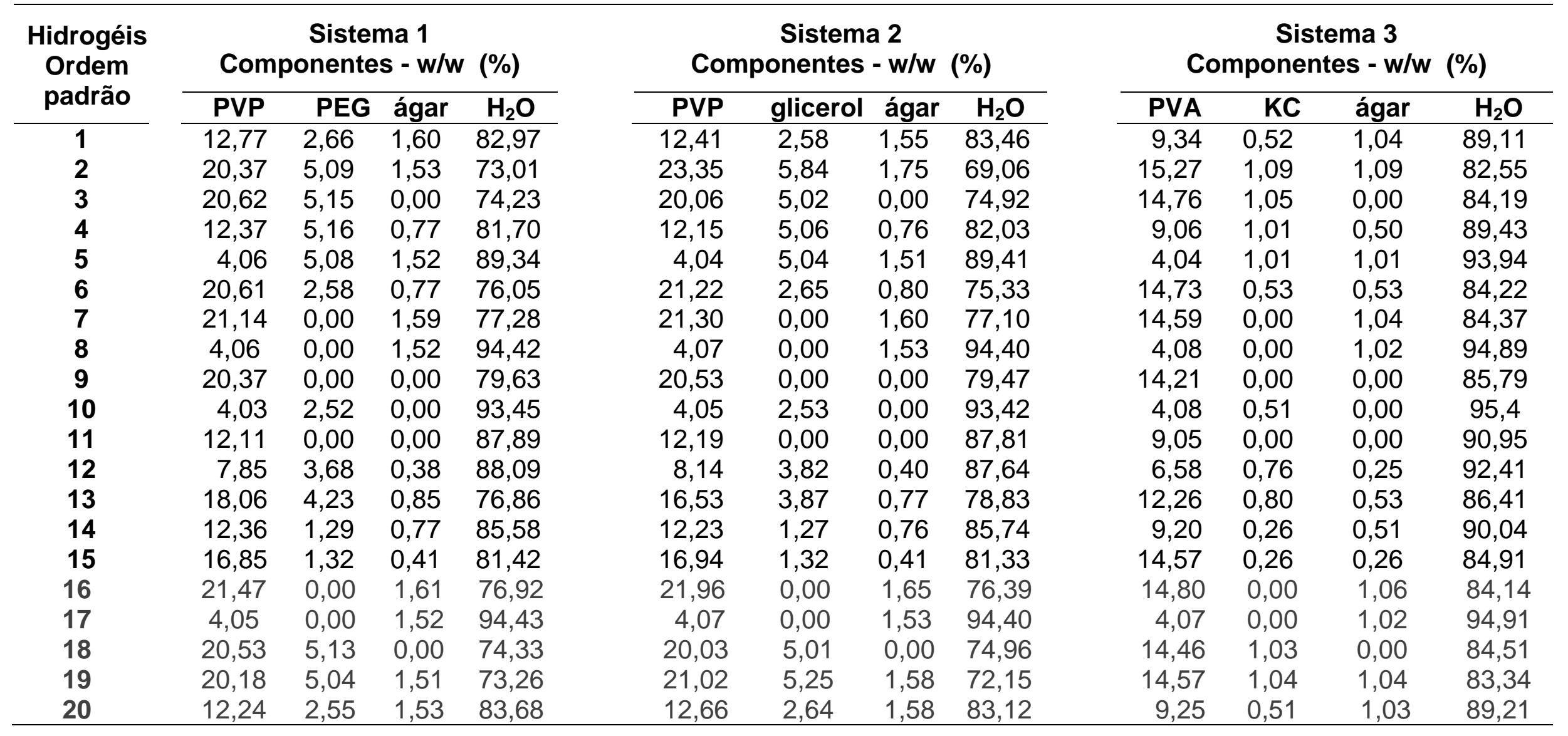




\subsection{Análise estatística}

\subsubsection{Fração gel}

\section{Sistema 1 e 2: PVP/PEG/ágar e PVP/glicerol/ágar, respectivamente}

Na FIG. 5.1 estão mostrados os resultados médios de fração gel e seus respectivos desvios-padrão obtidos experimentalmente para os hidrogéis do sistema 1 e 2, comparativamente aos resultados preditos obtidos através das equações 5.1 e 5.2, com o erro do modelo.

Fração gel

PVP/PEG/ágar - Obtido

XXX PV/PEG/ágar - Previsto

XXP/gli/ágar - Previsto

PVP/gli/ágar - Obtido

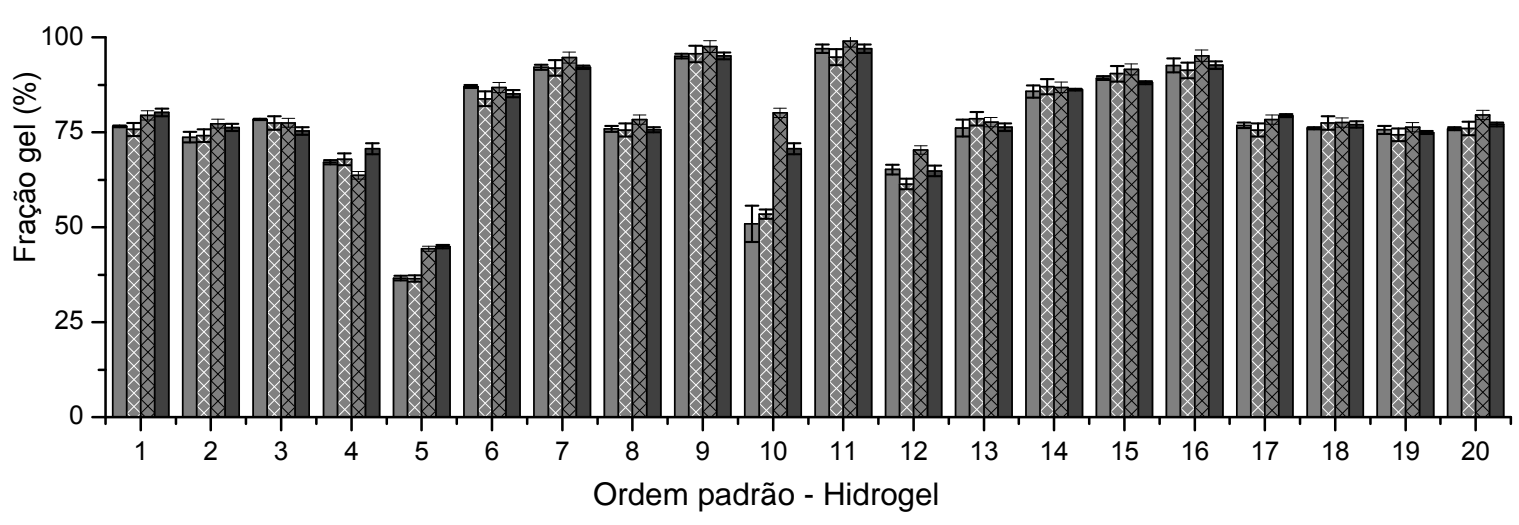

FIGURA 5.1 - Resultados de fração gel obtidos e previstos na análise dos hidrogéis sintetizados, para os sistemas PVP/PEG/ágar e PVP/glicerol/ágar.

As análises estatísticas dos resultados obtidos experimentalmente estão apresentadas nas TAB. A 1 e A 2 (Apêndice A).

As ANOVAs dos dois sistemas indicaram que o modelo quadrático é o que melhor se ajusta aos dados experimentais. A falta de ajuste $(F=0,24)$ para 0 sistema 2 não é significativa em relação ao erro puro e há uma chance de $91,21 \%$ de esta ocorrer devido ao ruído. As análises indicaram que os resultados estão bem ajustados aos modelos preditos, com coeficiente de determinação altamente significativo $\left(R^{2}\right.$ aj. $=97,59 \%$ e $98,32 \%$ para o sistema 1 e 2 , respectivamente) e portanto, $97,59 \%$ e $98,32 \%$ das variabilidades das frações gel podem ser explicadas pelos modelos, com nível de confiabilidade de $90 \%$.

As respostas que preveem os resultados de fração gel são dadas pelas equações 5.1 e 5.2 . 
$F G(\%)=-8,76 \cdot x_{1}+38,64 \cdot x_{2}-352,57 \cdot x_{3}+0,59 \cdot x_{4}-0,11 \cdot x_{1} \cdot x_{2}+3,64 \cdot x_{1} \cdot x_{3}$ $+0,14 \cdot x_{1} \cdot x_{4}+2,96 \cdot x_{2} \cdot x_{3}-0,49 \cdot x_{2} \cdot x_{3}+3,59 \cdot x_{3} \cdot x_{4}$

Sistema 1, sendo:

$\mathrm{FG}=$ Fração gel, concentrações \%, $x_{1}=[P V P], x_{2}=[P E G], x_{3}=$ [ágar] e $x_{4}=$ [água $]$

$F G(\%)=-1,95 \cdot x_{1}-59,38 \cdot x_{2}+480,28 \cdot x_{3}+0,91 \cdot x_{4}+0,79 \cdot x_{1} \cdot x_{2}-4,44 \cdot x_{1} \cdot x_{3}$ $+0,04 \cdot x_{1} \cdot x_{4}-4,12 \cdot x_{2} \cdot x_{3}+0,55 \cdot x_{2} \cdot x_{4}-5,0 \cdot x_{3} \cdot x_{4}$

Sistema 2, sendo:

$\mathrm{FG}=$ Fração gel, concentrações $\%, x_{1}=[P V P], x_{2}=$ [glicerol $], x_{3}=$ [ágar $]$ e $x_{4}=$ [água $]$

As regressões apresentadas, assim como as linhas de contorno apresentadas nas FIGs. 5.2 e 5.3 indicam que o ágar apresenta uma forte contribuição nos resultados de reticulação, seguidas pelo PEG/glicerol e por útimo do PVP. Além disso, observam-se pequenas interações entre todos os componentes da mistura.

Observa-se nas linhas de contorno dos dois sistemas (FIGs. 5.2 e 5.3) a diminuição da fração gel à medida que aumenta a concentração do plastificante (PEG e glicerol), para uma mesma concentração de ágar, sendo que no sistema 2 as variações são mais acentuadas a medida que se reduz a concentração de ágar. 


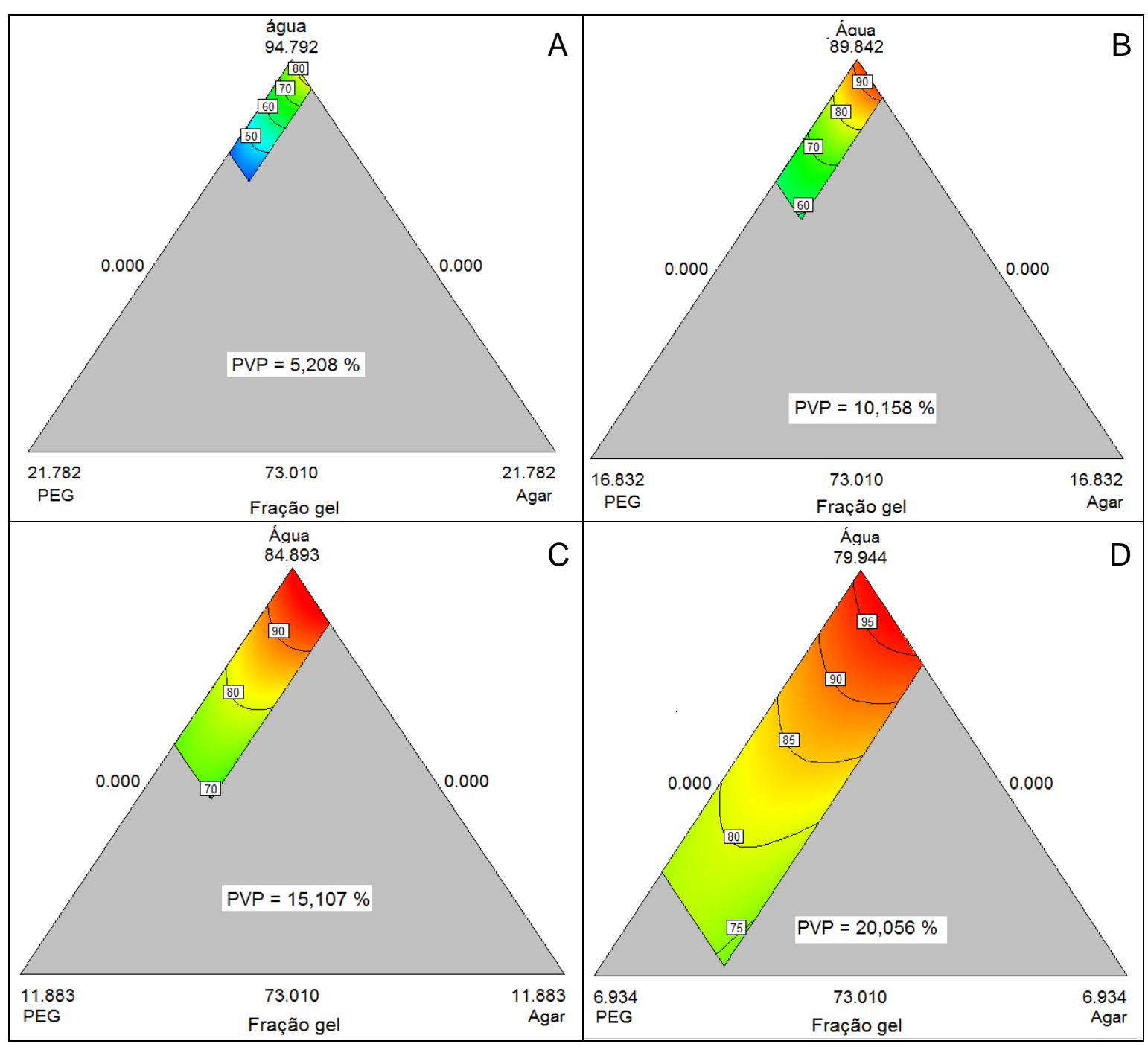

FIGURA 5.2 - Diagrama com as linhas de contorno das superfícies de resposta para fração gel no sistema PVP/PEG/ágar, sendo: (A) 5\% PVP, (B) 10\% PVP, (C) $15 \%$ PVP e (D) $20 \%$ PVP. 


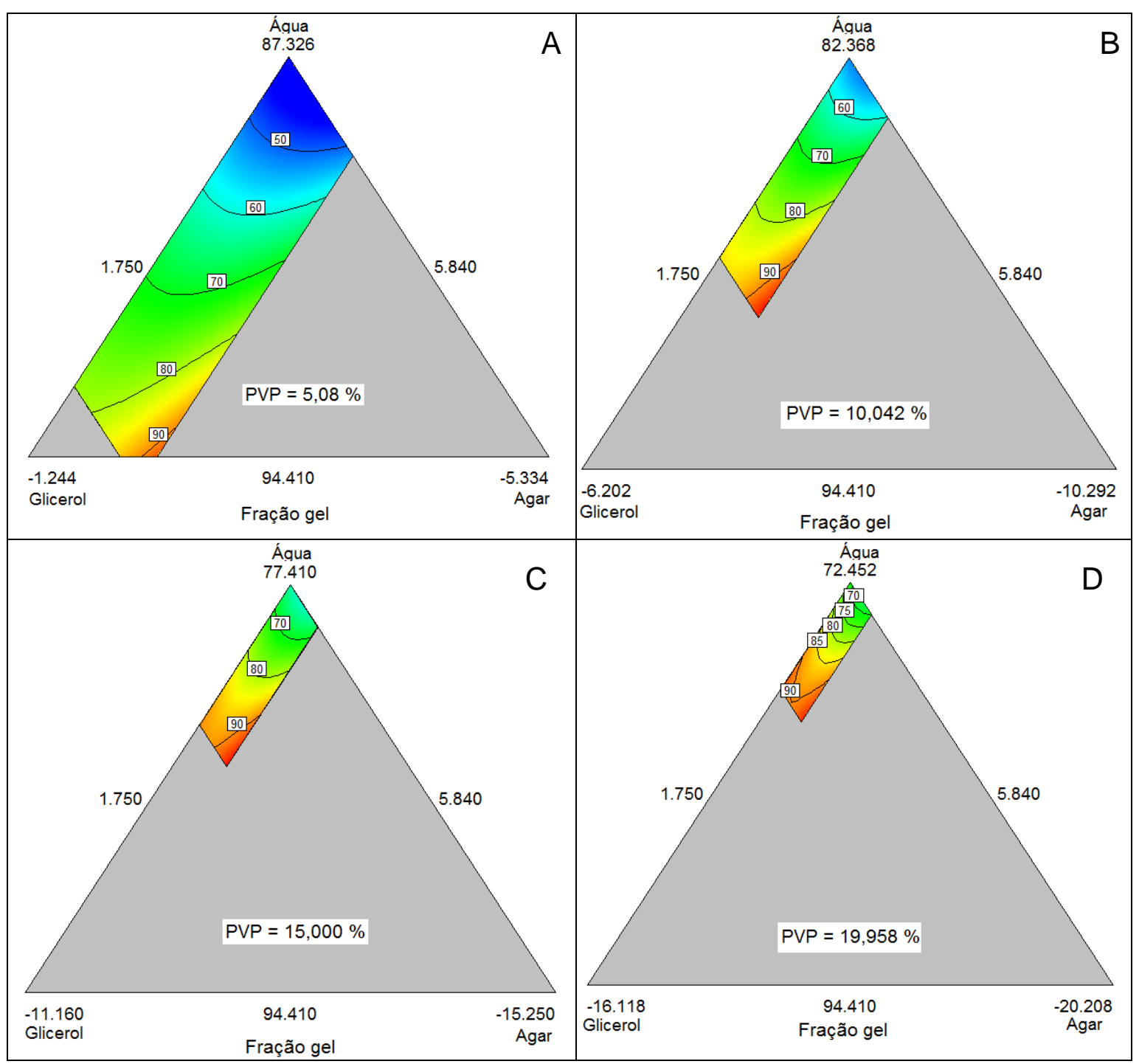

FIGURA 5.3 - Diagrama com as linhas de contorno das superfícies de resposta para fração gel no sistema PVP/glicerol/ágar, sendo: (A) 5\% PVP, (B) 10\% PVP, (C) $15 \%$ PVP e (D) $20 \%$ PVP.

Com os dados obtidos posteriormente (FIG. 5.29), para as formulações otimizadas, foi possível testar as regressões e verificou-se que os valores preditos estão de acordo com os resultados obtidos experimentalmente, confirmando que as regressões estão bem ajustadas ao modelo.

Segundo Ajji et al. (2005) e Benamer et. al. (2006), a insolubilidade da rede polimérica se amplia com o aumento da concentração do polímero devido à intensificação da densidade de ligações. No entanto, os diagramas com as linhas de contorno apresentados nas FIGs. 5.2 e 5.3 indicam que a redução da concentração de PVP não é tão expressiva na redução da fração gel quanto a redução do PEG e do glicerol. 
Por outro lado, como já era de esperar, o aumento da concentração de PEG, no sistema 1, FIG. 5.2, reduz o grau de reticulação dos hidrogéis (Ajji, et al., 2005), independentemente da concentração do PVP, uma vez que o PEG age como capturador de radical (Lugão et al.,1998 e Limoli et al., 2001). O mesmo é observado para o sistema 2, com o glicerol, FIG. 5.3. Em contrapartida, observase nos dois sistemas o aumento da fração gel para concentrações intermediárias de ágar independentemente da concentração de PVP e PEG/glicerol.

De acordo com Farhataziz e Rodgers (1987), embora a reação de reticulação seja sensível ao PEG e ao ágar, estes não fazem parte da rede formada pelo PVP, entretanto, Prasad et al., (2006) observaram a ocorrência de enxertia entre ágar e PVP, em hidrogéis preparados por irradiação de microondas, sugerindo que esse pode ser o motivo da influência do ágar, nos resultados de fração gel obtidos.

\section{Sistema 3: PVA x KC}

NA FIG. 5.4 estão apresentados os resultados médios de fração gel e seus respectivos desvios padrões obtidos para o sistema 3 comparativamente aos resultados previstos pela regressão representada pela equação 5.3. Os resultados mostram que não há diferenças significativas entre os resultados obtidos experimentalmente e os previstos.

Fração gel

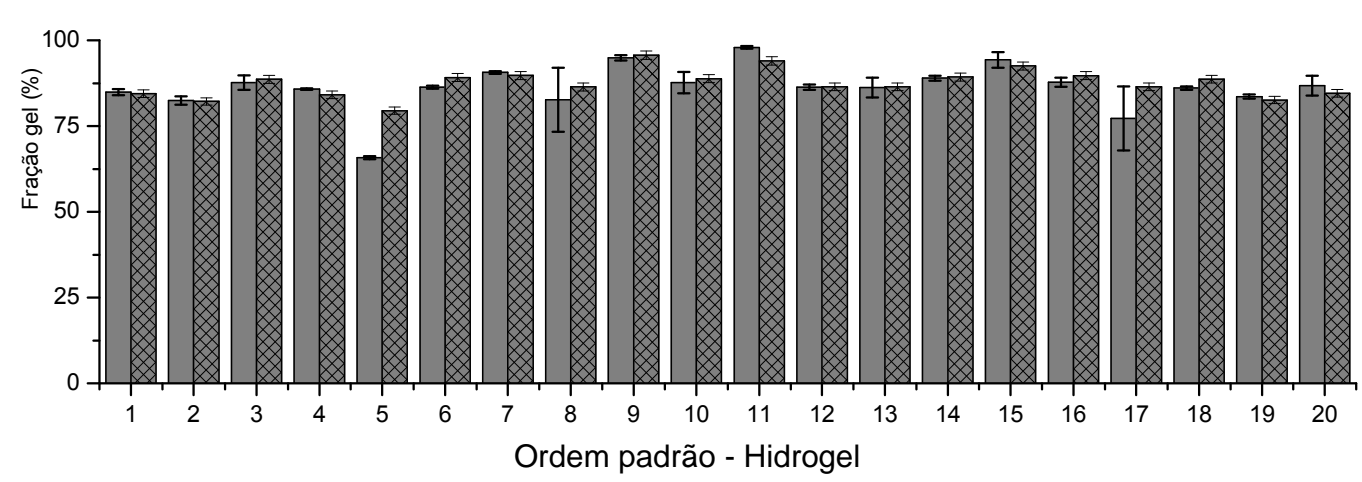

FIGURA 5.4 - Resultados de fração gel obtidos e previstos para o sistema 3 (PVA/KC/ágar).

O modelo linear foi o que melhor se ajustou aos dados experimentais obtidos no sistema e indica que os valores são proporcionais à quantidade dos 
seus componentes e não há interação entre eles. A ANOVA apresentada na tabela A 3.1 (Apêndice A) indica que o modelo para o sistema não apresenta falta de ajuste e os resultados estão ajustados ao modelo predito com fator de correlação $R^{2} a j .=74,18 \%$.

Com o resultado de fração gel obtido posteriormente (FIG. 5.29), para a formulação otimizada, foi possível testar a regressão e o resultado obtido é compatível com o valor predito, confirmando que a confiabilidade da regressão é de $90 \%$. A resposta para fração gel é representada pela equação 5.3 .

$$
F G(\%)=\quad-1,24 \cdot x_{1}-5,98 \cdot x_{2}+4,91 \cdot x_{3}+0,91 \cdot x_{4}
$$

Sistema 3, sendo:

$\mathrm{FG}=$ Fração gel, concentrações $\%, x_{1}=[P V A], x_{2}=[K C], x_{3}=$ [ágar $]$ e $x_{4}=$ [água $]$

A FIG. 5.5 que representa a projeção da superfície de resposta para o grau de reticulação dos hidrogéis de PVA, KC e ágar indica que, à medida que as concentrações de ágar e KC são reduzidas simultaneamente, é possível obter resultados crescentes de fração gel, sendo que o maior índice de reticulação pode ser obtido para o hidrogel de PVA puro, sendo maior quanto maior for a concentração do PVA, porém nunca inferior a ca. $82 \%$. 


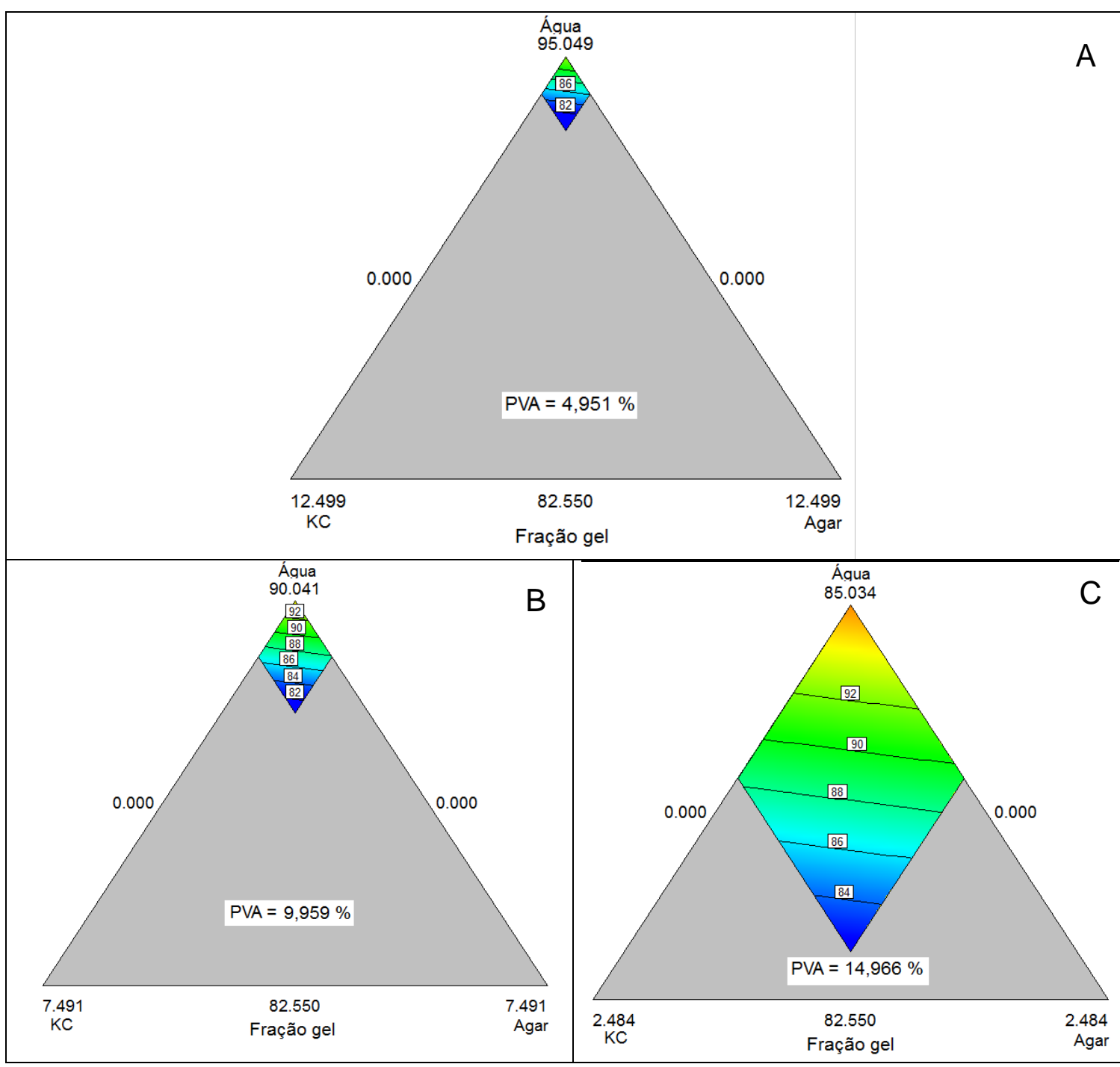

FIGURA 5.5 - Linhas de contorno das superfícies de resposta do grau de intumescimento no equilíbrio no sistema PVA/KC/ágar (A) 5\% PVA, (B) 10\% PVA e (C) 15\% PVA.

\subsubsection{Intumescimento no equilíbrio}

De um modo geral, a capacidade de intumescimento depende da hidrofilicidade da cadeia polimérica (Benamer et al., 2006), da concentração dos componentes, quando esta for o caso, do tamanho e tipo de estrutura do poro (Gurny et al., 1982 and Ganji et al., 2010), da cristalinidade do polímero (Gupta et al., 2002), do conteúdo iônico da solução (Omidian e Park, 2008), da geometria do hidrogel (Gurny et al., 1982) e da densidade de reticulação (Carvalho e Grosso, 2006). 


\section{Sistemas 1 e 2: PVP/PEG/ágar e PVP/glicerol/ágar, respectivamente.}

Os resultados de intumescimento no equilíbrio obtidos experimentalmente para os hidrogéis de PVP/PEG/ágar e PVP/glicerol/ágar estão apresentados na FIG. 5.6, comparativamente aos resultados previstos, representados pelas equações 5.4 e 5.4 .

As regressões obtidas a partir de todos os resultados experimentais não permitiram chegar a um modelo estatístico que pudesse explicar todos os dados, tanto para o sistema 1 quanto para o sistema 2. No entanto, ao remover alguns pontos do planejamento (sistema 1: hidrogéis de ordem padrão 1, 2, 12, 14 e 17 e sistema 2: hidrogéis de ordem padrão: $2,3,4,6,7,16$ e18) e repetindo a análise com os dados reduzidos, foram obtidos os modelos quadráticos representados pelas equações 5.4 para o sistema 1: PVP/PEG/ágar e equação 5.5 para o sistema 2: PVP/glicerol/ágar.

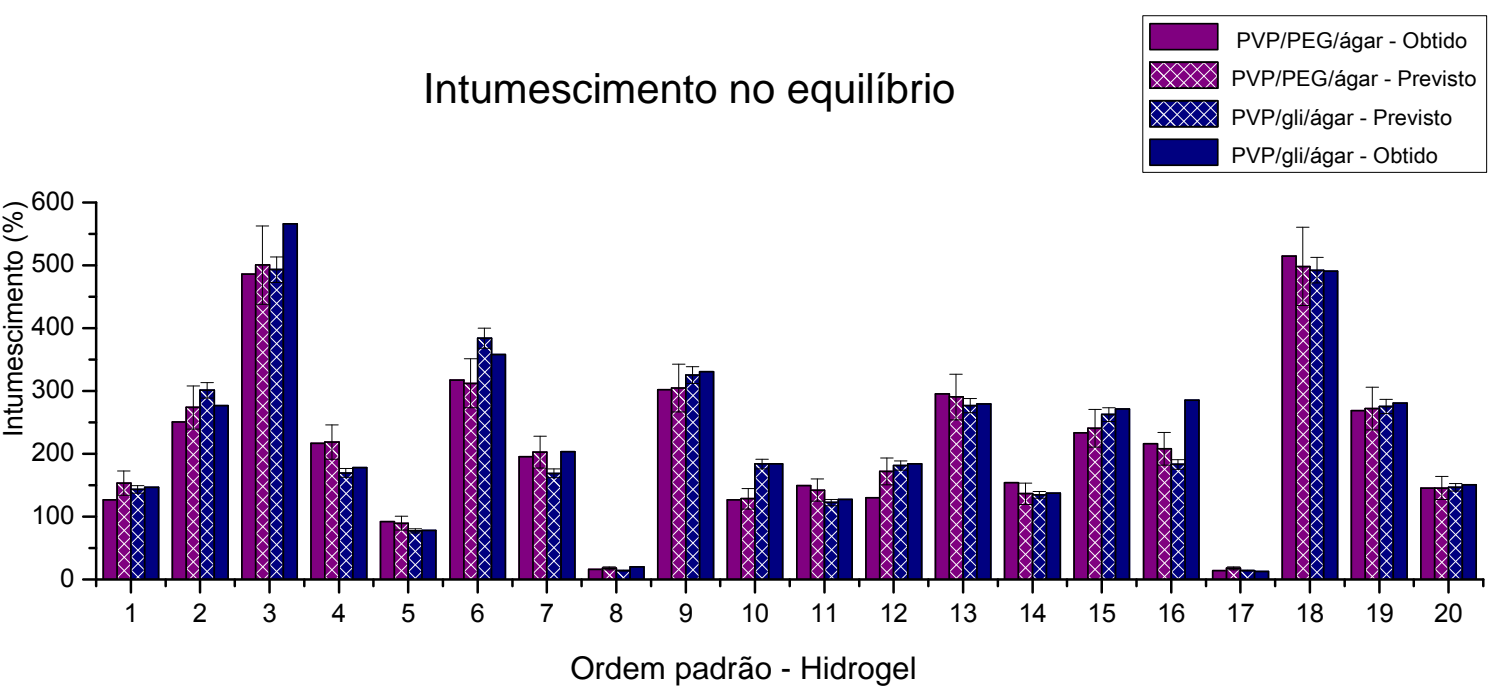

FIGURA 5.6 - Resultados de intumescimento no equilíbrio para os hidrogéis cujas composições estão apresentadas na TAB. 5.1.

As análises estatísticas dos resultados reduzidos estão apresentadas nas TAB. B 1 e B 2 (Apêndice B) e indicam que apenas a Eq. 5.5 apresentou falta de ajuste, porém, a mesma se mostrou não significativa. As análises indicaram também que os resultados reduzidos estão bem ajustados aos modelos preditos para os dois sistemas, com fator de correlação $R^{2} a j .=99,14 \%$ e $99,83 \%$ para o sistema 1 e 2, respectivamente, indicando que $99,14 \%$ e $99,83 \%$ das variabilidades podem ser explicadas pelos modelos. 
Com os resultados de intumescimento obtidos posteriormente, para as formulações otimizadas, apresentados na FIG. 5.30, foi possível testar as regressões e os resultados obtidos se mostraram compatíveis com os valores preditos.

$$
\begin{aligned}
\operatorname{Int}(\%)= & 38,32 \cdot x_{1}-266,91 \cdot x_{2}+4898,7 \cdot x_{3}-0,27 \cdot x_{4}+3,03 \cdot x_{1} \cdot x_{2}-54,33 \cdot x_{1} \cdot x_{3} \\
& -0,28 \cdot x_{1} \cdot x_{4}-60,02 \cdot x_{2} \cdot x_{3}+3,17 \cdot x_{2} \cdot x_{4}-49,58 \cdot x_{3} \cdot x_{4}
\end{aligned}
$$

Sistema 1, sendo:

Int $=$ intumescimento, concentrações $\%, x_{1}=[P V P], x_{2}=[P E G], x_{3}=[a ́ g a r] ~ e ~ x_{4}=$ [água $]$

$$
\begin{aligned}
\operatorname{Int}(\%)= & 86,07 \cdot x_{1}-1078,69 \cdot x_{2}+4179,83 \cdot x_{3}+0,54 \cdot x_{4}+11,38 \cdot x_{1} \cdot x_{2} \\
& -48,86 \cdot x_{1} \cdot x_{3}-0,91 \cdot x_{1} \cdot x_{4}-39,08 \cdot x_{2} \cdot x_{3}+11,60 \cdot x_{2} \cdot x_{4}-42,43 \cdot x_{3} \cdot x_{4}
\end{aligned}
$$

Sistema 2, sendo:

Int $=$ intumescimento, concentrações $\%, x_{1}=[P V P], x_{2}=$ [glicerol], $x_{3}=$ [ágar $]$ e $x_{4}=$ [água]

A regressão obtida para o sistema 1 (PVP/PEG/ágar) indica uma influência muito grande do ágar e do PEG sozinhos no sistema, além de importantes interações entre os componentes. Enquanto que para o sistema 2 (PVP/glicerol/ágar) a regressão também apresenta uma forte influência principalmente do ágar e do glicerol, seguida pelo PVP e interações fracas entre os componentes, principalmente entre glicerol-água e PVP-glicerol.

As linhas de contorno das superfícies de resposta, apresentadas na FIGs. 5.7 e 5.8, ilustram as influências dos componentes nos sistemas 1 e 2 , além das diferenças do perfil de intumescimento entre ambos. Tais diferenças devem-se às variações de hidrofilicidade entre o PEG e o glicerol, das diferenças entre as interações de cada um dos plastificantes com os demais componentes, além das diferenças estruturais em suas moléculas, que permitem ao glicerol maior tendência à captura de radicais livres que o PEG.

A Fig. 5.7 indica que em altas proporções de PVP e PEG é possível obter altos níveis de intumescimento, sendo que 0 aumento do ágar reduz 0 intumescimento na medida em que aumenta a concentração de PEG. 


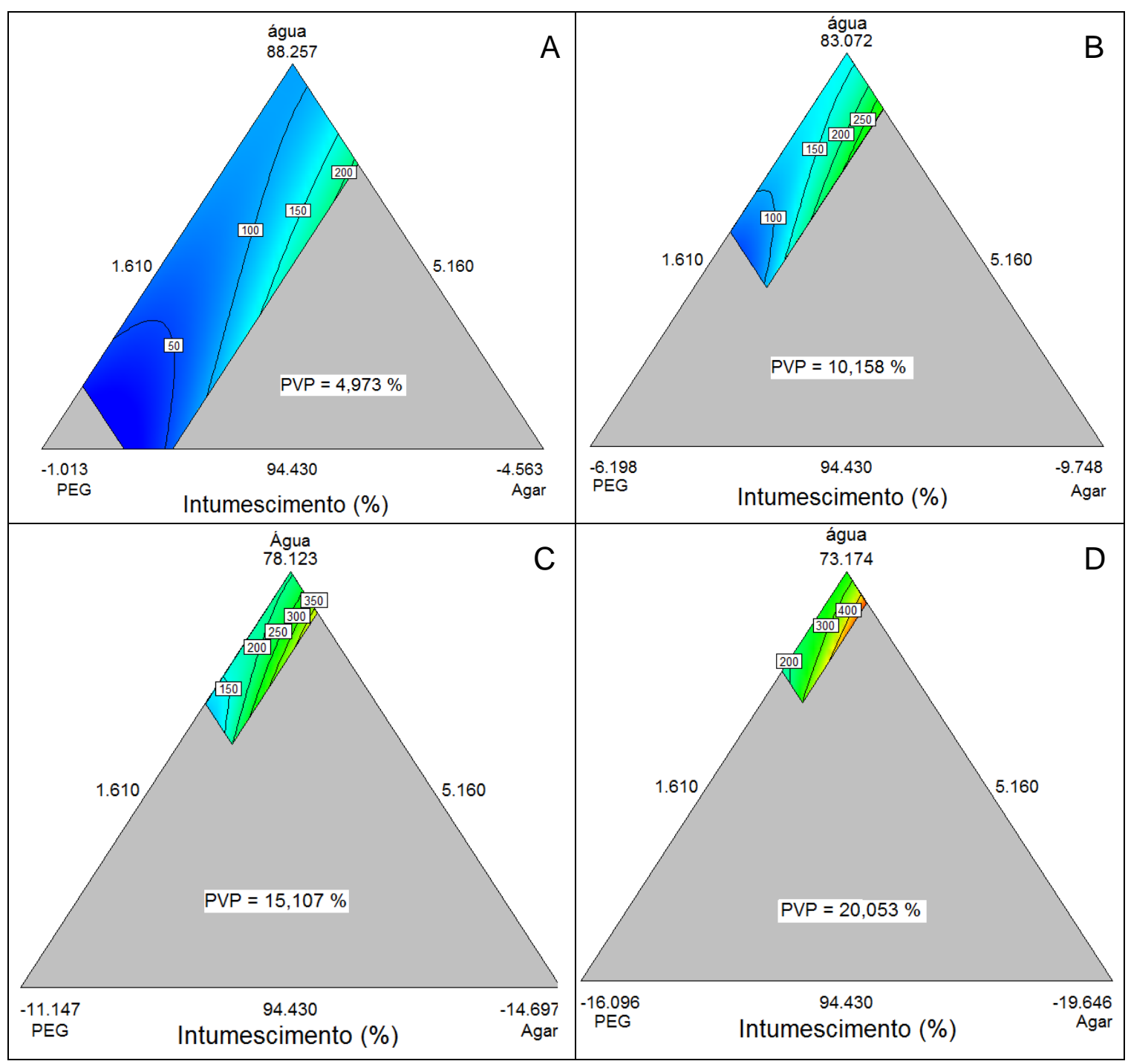

FIGURA 5.7 - Linhas de contorno das superfícies de resposta geradas pelas regressões que representam o grau de intumescimento dos hidrogéis de PVP/PEG/ágar, sendo: (A) 5\% PVP, (B) 10\% PVP, (C) 15\% PVP e (D) 20\% PVP. 


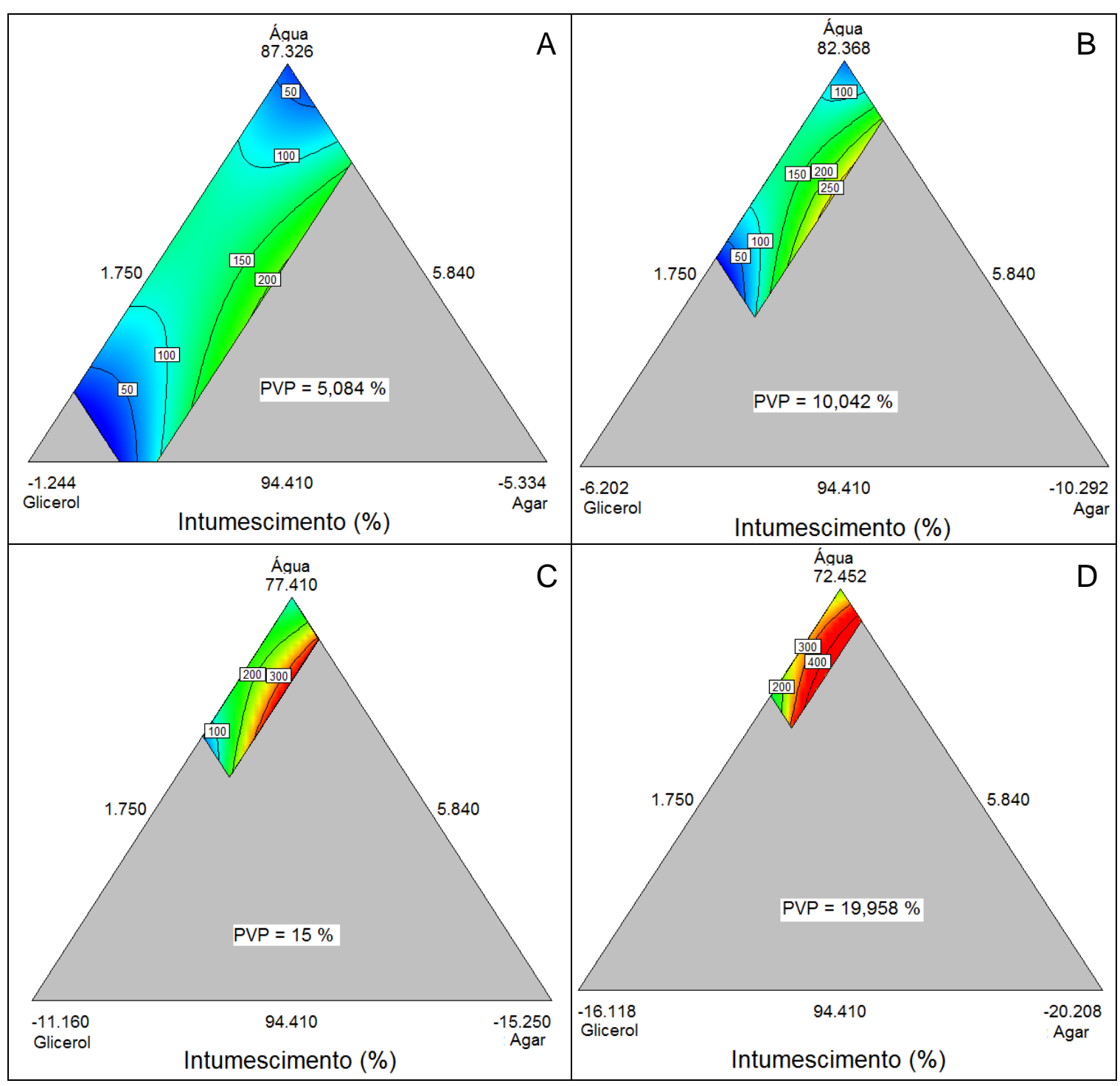

FIGURA 5.8 - Linhas de contorno das superfícies de resposta geradas pelas regressões que representam o grau de intumescimento para dos hidrogéis de PVP/glicerol/ágar, sendo (A) 5\% PVP, (B) 10\% PVP, (C) 15\% PVP e (D) 20\% PVP.

Estudos realizados por Aji et al. (2005), concluiram que o aumento da concentração de PVP diminui o intumescimento devido ao aumento da densidade de reticulação, no entanto, a partir do estudo aqui apresentado, que é mais amplo, observa-se que, aumentando a concentração de PVP de ca. $5 \%$ para ca. $20 \%$, se obtém o intumescimento máximo, no equilíbrio, variando de ca. 50\% para ca. $300 \%$, indicando que o aumento da concentração de PVP favorece o aumento do intumescimento. Tal resultado pode ser justificado pelo fato de o aumento da densidade de reticulação aumentar a resistência do hidrogel contrabalanceando a força exercida pela água sobre a rede (Peppas et al., 2000), uma vez que uma 
baixa concentração de PVP pode não ser suficiente para formação adequada da rede. Por outro lado, o aumento do índice de intumescimento com o aumento da concentração de PEG observado corrobora com os resultados obtidos por Ajji et al. (2005), uma vez que o PEG compete com o PVP pelos radicais livres inibindo a reticulação e aumenta a permeabilidade da água devido à sua natureza hidrofílica (Parra et al., 2004).

Para o sistema PVP/glicerol/ágar, as linhas de contorno com diferentes concentrações de PVP indicam que os maiores índices de intumescimento são obtidos em alta concentração de PVP e concentração intermediária de glicerol, na ausência de ágar.

Para os dois sistemas estudados, os resultados indicam que o ágar apresenta forte influência no intumescimento, ao contrário do que pode ser observado nos resultados de fração gel, indicando que a relação entre fração gel e intumescimento não é direta.

As linhas de contorno das superfícies de resposta do sistema 1, FIG. 5.7 indicam menores resultados de intumescimento na ausência de PEG e na máxima concentração de ágar, simultaneamente, assim como para o sistema 2 , que também indicam o favorecimento do intumescimento na redução da concentração do ágar. Entretanto, sabe-se que o ágar, assim como os demais polissacarídeos, degrada quando submetido à radiação (Aliste et al., 2000; Varshney, 2007, Yang et al., 2008). Desta forma, a influência do ágar nos sistemas sugere a formação de rede semi-interpenetrante (SIPN) ou enxertia, tendo em vista que Prasad et al. (2006) estudaram a enxertia de ágar-PVP e KC$P V P$, reticulados por irradiação de micro-ondas, na presença de persulfato de potássio como iniciador redox solúvel em água, e comprovaram a presença de rede semi-interpenetrante (SIPN); além disso, Abad et al. (2003), que estudaram blendas de PVP com KC, reticuladas por radiação gama com dose de até 25 kGy observaram que

"Gamma irradiation of PVP-KC blends would result in the simultaneous crosslinking of PVP, degradation of KC, and grafting of KC to PVP. A combination of these processes may form a PVP-KC hydrogel with a network structure of (a) a semi-interpenetrating polymer network (SIPN) whereby KC is physically entangled within the crosslinked PVP and (b) a grafted network whereby KC is grafted into the PVP backbone" (Abad et al., 2003). 
Em sua pesquisa, Abad et al. (2003) obtiveram o intumescimento máximo com a formação de uma rede SIPN/ enxertia e também observaram que, aumentando a concentração de PVP, o nível de reticulação aumenta com a redução da enxertia; além disso, a enxertia aumenta com o aumento da KC independentemente da concentração de PVP, o que possivelmente também acontece na rede com PVP/ágar.

\section{Sistema 3: PVA/KC/ágar}

Os resultados de intumescimento obtidos para o sistema PVA/KC/ágar estão apresentados na FIG. 5.9, comparativamente aos resultados previstos pela equação 5.6 .
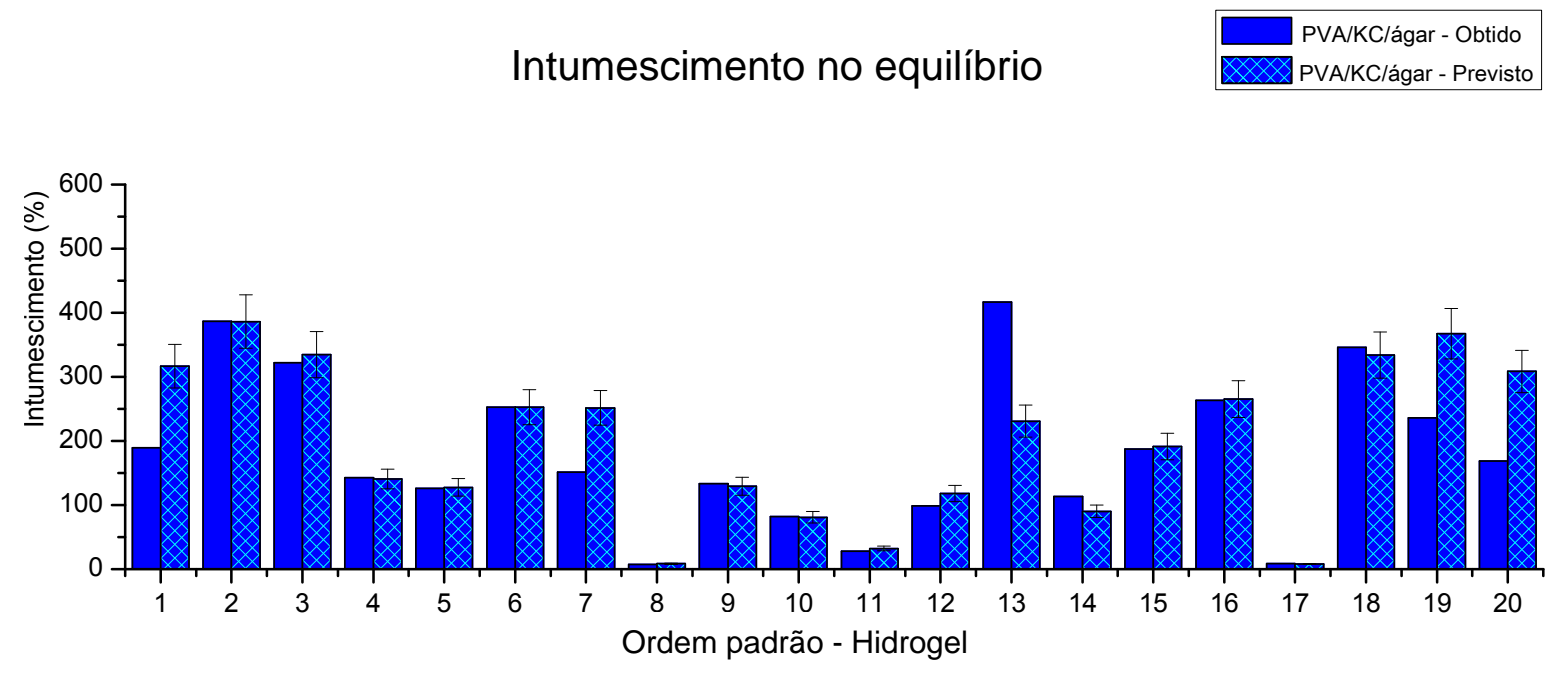

FIGURA 5.9 - Resultados de intumescimento no equilíbrio, para os hidrogéis de $\mathrm{PVA} / \mathrm{KC} /$ ágar.

Assim como nos sistemas 1 e 2 não foi possível obter um modelo estatístico com todos os resultados obtidos experimentalmente para o sistema 3. Por isso, também foram desconsiderados alguns pontos do planejamento (hidrogéis de ordem padrão: 1, 7, 12, 13, 14, 18 e 19). A análise estatística dos resultados reduzidos, obtidos experimentalmente, está apresentada na TAB. B 3.1 (Apêndice B). $O$ modelo quadrático obtido com os dados reduzidos indica que $O$ modelo é significante e não apresenta falta de ajuste. $O$ coeficiente de determinação ( $R^{2}$ aj.) obtido foi $99,31 \%$. 
O modelo foi testado posteriormente, com o resultado obtido para o hidrogel otimizado, apresentado na FIG. 5.30 e a diferença entre o resultado obtido e predito é de $12 \%$, apenas $1,24 \%$ superior ao erro do modelo, podendo ser considerado compatível.

A seguir está apresentada a regressão 5.6 obtida para o sistema 3 e na FIG. 5.10 as linhas de contorno, para as superfícies de resposta que representam blendas, com 5, 10 e $15 \%$ de PVA.

$$
\begin{aligned}
\operatorname{lnt}(\%)= & -61,36 \cdot x_{1}-34620,52 \cdot x_{2}+43246,67 \cdot x_{3}-2,68 \cdot x_{4}+352,75 \cdot x_{1} \cdot x_{2} \\
& -436,05 \cdot x_{1} \cdot x_{3}+1,01 \cdot x_{1} \cdot x_{4}-161,30 \cdot x_{2} \cdot x_{3}+351,77 \cdot x_{2} \cdot x_{4}-435,70 \cdot x_{3} \cdot x_{4}
\end{aligned}
$$

Sistema 3, sendo:

Int = intumescimento, concentrações $\%, x_{1}=[P V A], x_{2}=[K C], x_{3}=[a ́ g a r] ~ e ~ x_{4}=$ [água $]$

A equação 5.6 indica uma forte influência da $K C$ e do ágar sozinhos na resposta, seguida por interações menos influentes entre PVP-ágar, ágar-água, PVA-KC, KC-água e KC-ágar e baixa influência do PVA sozinho e interagindo com a água.

$\mathrm{Na}$ FIG. 5.10 observa-se que altos valores de intumescimento podem ser obtidos para misturas com ca. $10 \%$ e $15 \%$ de PVA. Além disso, a KC pode favorecer o intumescimento do hidrogel, o que também foi observado por Varshney (2007). Entretanto, os menores resultados são obtidos à medida que se aumenta a concentração da $\mathrm{KC}$ na mistura para uma concentração intermediária de ágar, ou seja, por volta de $0,5 \%$. 


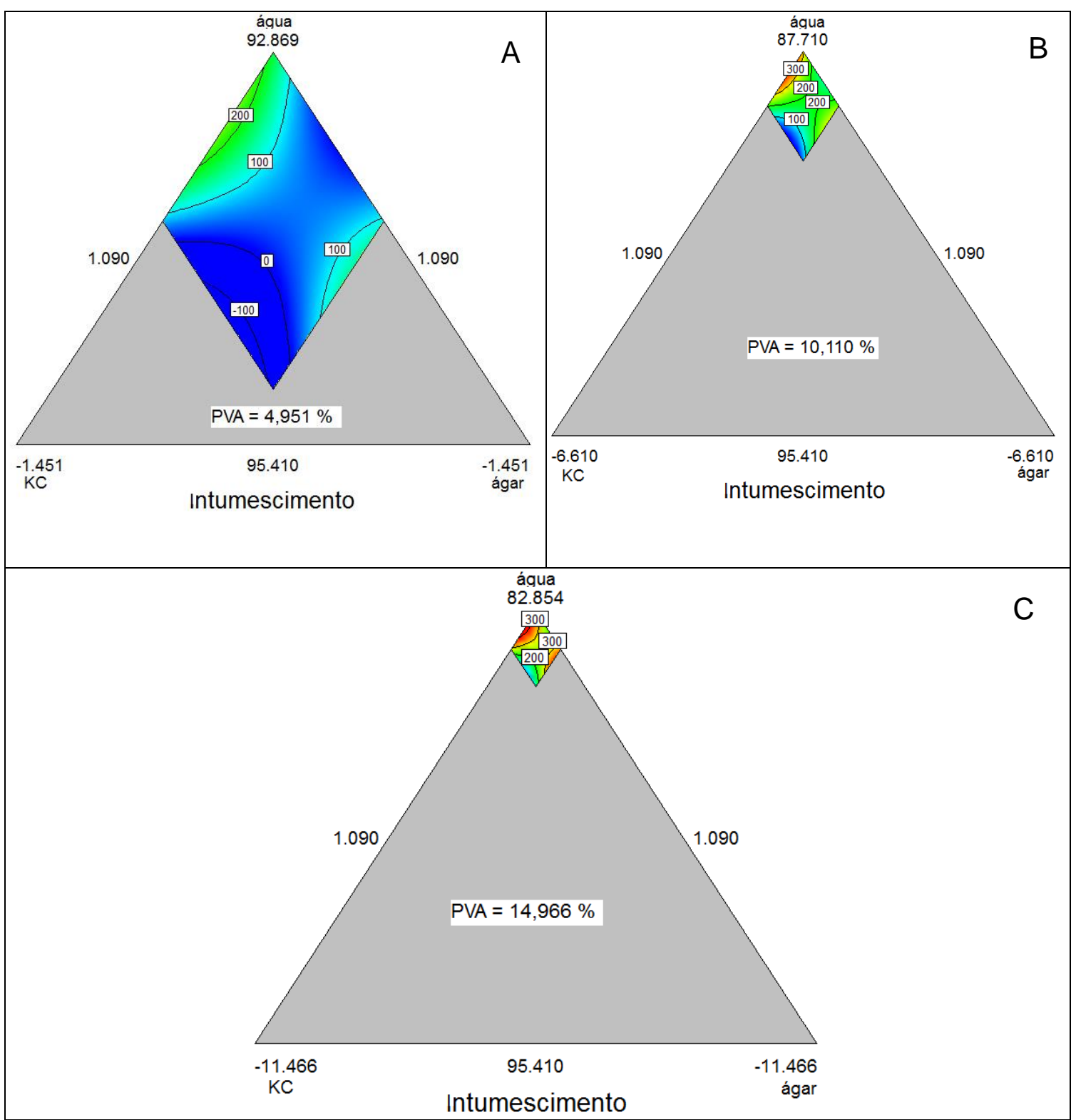

FIGURA 5.10 - Linhas de contorno das superfícies de resposta do grau do grau de ntumescimento no equilíbrio do sistema PVA/KC/ágar, sendo (A) $5 \%$ PVA, (B) 10\% PVA e (C) 15\% PVA.

\subsubsection{Propriedades mecânicas}

Uma das maneiras para obter bom comportamento mecânico é, principalmente, pela variação do polímero e do grau de reticulação (Kudela, 1987), tendo em vista que as propriedades mecânicas dos polímeros dependem de vários fatores, entre os quais massa molar, linearidade da cadeia, cristalinidade, natureza química, além do fato de que as propriedades podem ser influenciadas pela adição de plastificante, fatores de processamento (Nielsen e 
Landel, 1994; Alcântara et al., 2012) como, por exemplo, cisalhamento, pressão e temperatura.

Por outro lado, os resultados obtidos na avaliação das propriedades mecânicas também são muito influenciados por variáveis externas, independentemente das características intrínsecas do material analisado, como por exemplo, temperatura, velocidade, etc. Neste trabalho os resultados não apresentaram a uniformidade desejada, o que, possivelmente, se deve às grandes variações observadas nas propriedades dos hidrogéis sintetizados, nas variações de processamento conforme descrição na seção 5.1 e nas limitações do equipamento utilizado.

Mesmo considerando que a escolha do equipamento para realização dos ensaios deveu-se à sua alta sensibilidade e delicadeza que permitem a avaliação das propriedades de materiais muito frágeis, como é o caso principalmente de alguns dos hidrogéis preparados, a medida das propriedades mecânicas ficaram sujeitas a variáveis externas que interferiram nos resultados:

- Algumas amostras apresentaram autodeformação em consequência da força exercida pelo seu próprio peso, enquanto que outras eram muito frágeis e quebradiças dificultando o manuseio e a avaliação das mesmas; motivos que levaram à definição do formato e dimensionamento do corpo de prova utilizado, diferentemente do recomendado pela norma utilizada, assim como redução na velocidade de tração para os hidrogéis mais frágeis.

- Durante a aplicação da força de tensão ocorre alinhamento das cadeias poliméricas e expulsão da água do seu interior, podendo acarretar alterações significativas na área da seção transversal, comprometendo a precisão da medida de tensão. Neste caso a tensão é totalmente baseada nas dimensões originais do corpo de prova e estas dimensões variam no decorrer do teste, principalmente quando se têm grandes deformações; portanto as curvas obtidas foram de tensão-deformação de engenharia que não fornece boas indicações das características de tensão e deformação de alguns hidrogéis.

- Foi observada a redução da área da seção transversal em algumas amostras do sistema PVA/KC/ágar, levando à formação acentuada de "pescoço", enquanto que em outros hidrogéis a redução da espessura foi observada ao longo de todo o corpo de prova, inclusive na região onde o mesmo estava preso ao suporte que o prendia ao equipamento. Além das dificuldades para avaliação 
desses hidrogéis, que escapam do suporte durante a elongação, a medida de deformação desses hidrogéis ficou comprometida, tendo em vista que o equipamento não dispõe de recurso para que a medida de deformação seja efetuada num região específica, ou seja, a medida está totalmente associada ao distanciamento das garras.

- Além dos fatores descritos acima alguns hidrogéis são altamente escorregadios, o que dificulta mantê-los fixos nos suportes, tanto para os ensaios de tração quanto de perfuração.

Portanto, as dificuldades apresentadas refletiram nos resultados finais, principalmente tendo em vista, que cada um dos problemas não se repete para todas as amostras. Além disso, sabe-se que nos hidrogéis não há formação de uma rede homogênea conforme observado por Jovanovic' et al. (2011) e anteriormente já relatado por Rosiak e esta condição interferiu significantemente no modelamento matemático obtido para cada uma das propriedades apresentadas a seguir. Por isso as regressões determinadas a partir dos resultados obtidos, assim como as interpretações decorrentes, devem ser vistas com cautela.

\subsubsection{Resistência à tração}

\section{Sistemas 1 e 2: PVP/PEG/ágar x PVP/glicerol/ágar, respectivamente}

As análises estatísticas dos dados indicaram a obtenção de um modelo quadrático com alta variabilidade explicada somente após a remoção dos resultados de ordem padrão: 1, 2 12, 14 e 17 para o sistema 1 e ordem padrão: 2, $3,4,6,7,16$ e 18 para o sistema 2.

Todos os resultados de resistência à tensão na ruptura, obtidos experimentalmente para os sistemas 1 e 2 estão apresentados na FIG. 5.11, comparativamente aos preditos pelas regressões obtidas com os dados reduzidos. 


\section{Resistência à tração}
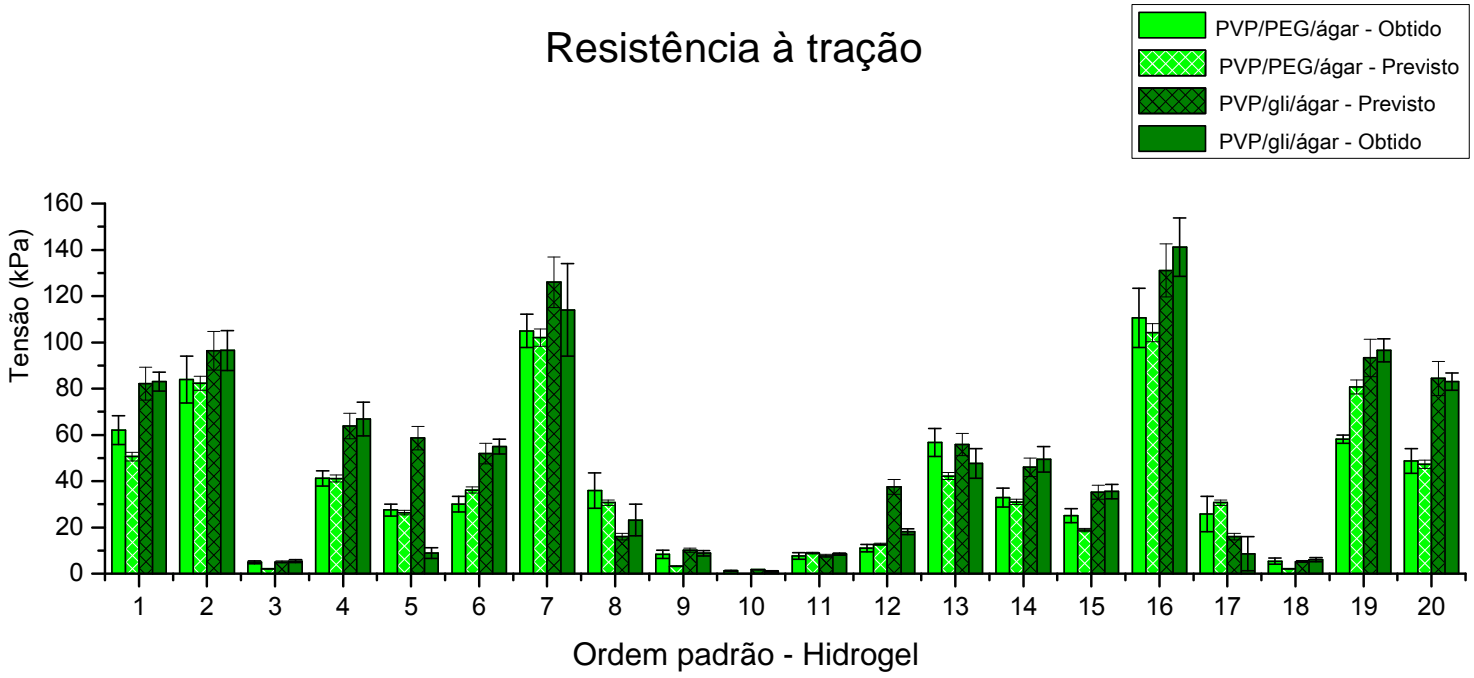

FIGURA 5.11 - Resultados de resistência à tensão na ruptura, obtidos experimentalmente e preditos para os hidrogéis dos sistemas 1 e 2 .

As regressões obtidas são representadas pelas Eq. 5.7 e 5.8 e as análises estatísticas dos resultados reduzidos estão apresentadas nas TAB. C $1 \mathrm{e}$ C 2 (Apêndice C).

$$
\begin{aligned}
\bar{\sigma}(\mathrm{kPa})= & -4,02 \cdot \mathrm{x}_{1}+224,31 \cdot \mathrm{x}_{2}-807,93 \cdot \mathrm{x}_{3}+0,05 \cdot \mathrm{x}_{4}-2,41 \cdot \mathrm{x}_{1} \cdot \mathrm{x}_{2}+11,12 \cdot \mathrm{x}_{1} \cdot \mathrm{x}_{3} \\
& +0,05 \cdot \mathrm{x}_{1} \cdot \mathrm{x}_{4}+4,24 \cdot \mathrm{x}_{2} \cdot \mathrm{x}_{3}-2,34 \cdot \mathrm{x}_{2} \cdot \mathrm{x}_{4}+8,23 \cdot \mathrm{x}_{3} \cdot \mathrm{x}_{4}
\end{aligned}
$$

Sistema 1, sendo:

$\bar{\sigma}=$ Tensão na ruptura, concentrações $\%, x_{1}=[P V P], x_{2}=[P E G], x_{3}=$ [ágar] e $x_{4}=$ [águaa $]$

$$
\begin{aligned}
\bar{\sigma}(\mathrm{kPa})= & -15,01 \cdot \mathrm{x}_{1}+98,95 \cdot \mathrm{x}_{2}-157,70 \cdot \mathrm{x}_{3}-0,51 \cdot \mathrm{x}_{4}-1,51 \cdot \mathrm{x}_{1} \cdot \mathrm{x}_{2} \\
& +4,70 \cdot \mathrm{x}_{1} \cdot \mathrm{x}_{3}+0,22 \cdot \mathrm{x}_{1} \cdot \mathrm{x}_{4}-1,69 \cdot \mathrm{x}_{2} \cdot \mathrm{x}_{3}-0,88 \cdot \mathrm{x}_{2} \cdot \mathrm{x}_{4}+1,75 \cdot \mathrm{x}_{3} \cdot \mathrm{x}_{4}
\end{aligned}
$$

Sistema 2, sendo:

$\bar{\sigma}=$ Tensão na ruptura, concentrações $\%, x_{1}=[P V P], x_{2}=$ [glicerol], $x_{3}=$ [ágar] e $x_{4}=$ [água]

A regressão obtida para o sistema 1 (PVP/PEG/ágar) apresentou falta de ajuste, porém esta não se apresentou significativa e as variabilidades dos resultados experimentais, reduzidos, explicados pelos modelos dos dois sistemas, são $R_{2}$ aj. $=96,23 \%$ para o sistema 1 e $R_{2}$ aj. $=95,98 \%$ para o sistema 2 . No entanto, ao testar os modelos com os dados obtidos posteriormente, a partir das formulações otimizadas, FIG. 5.31, os resultados mostram diferenças consideráveis entre os obtidos e os preditos pelas regressões, ou seja, 11,9 $\mathrm{kPa}$ contra $34,8 \mathrm{kPa}$ respectivamente para o sistema 1 e $51,9 \mathrm{kPa}$ contra 72,2 kPa 
para o sistema 2. Por outro lado, a aplicação dos modelos nos resultados obtidos para os 2 sistemas não indicam variações significativas entre os resultados obtidos e os preditos pelas regressões, conforme apresentado na FIG. 5.11 sugerindo que a remoção dos pontos indicados não interferiu significantemente nos resultados obtidos. No entanto, não se pode afirmar que os resultados obtidos apresentam significância estatística.

As regressões 5.7 e 5.8 obtidas sugerem interações fracas entre os componentes da mistura, sendo que o PEG, o glicerol e principalmente o ágar, sozinhos, são os que mais contribuem para os resultados de tensão na ruptura. Além disso, a influência do PEG diminui com o aumento da concentração do PVP, assim como o glicerol, porém este de forma menos acentuada.

As linhas de contorno das superfícies de resposta, geradas pelo software a partir das regressões obtidas, estão apresentadas nas FIGs. 5.12 e 5.13 e ilustram a forte influência do ágar no aumento da resistência à tensão, seguida mais fracamente pela influência do PEG e glicerol. 


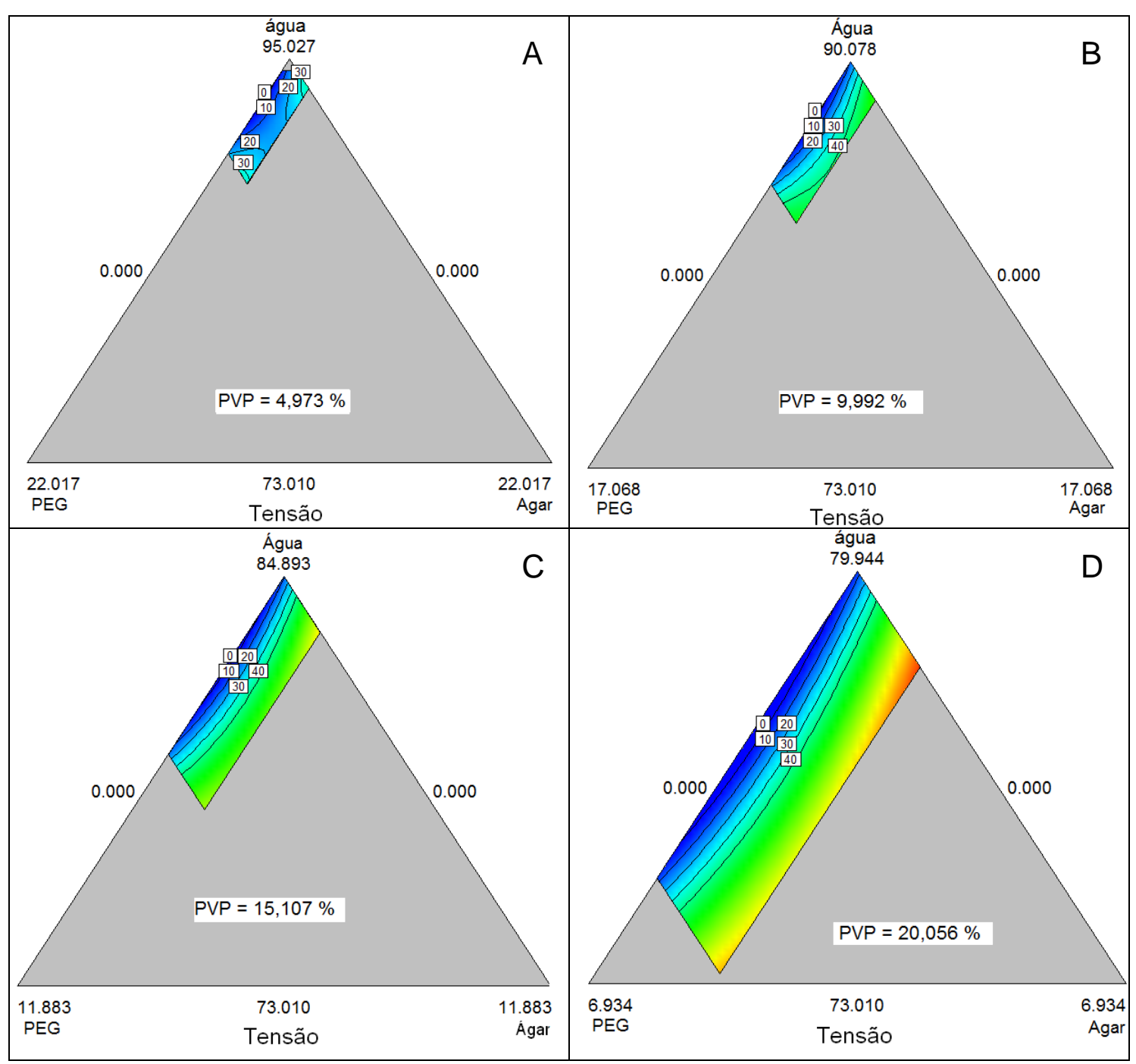

FIGURA 5.12 - Diagrama com as linhas de contorno para a resistência à tensão para o sistema PVP/PEG/ ágar, com (A) 5\% de PVP, (B) 10\% de PVP, (C) $15 \%$ PVP e (D) $20 \%$ PVP.

A resposta observada para o sistema 1 corrobora com os resultados obtidos por Hilmy et al. (1993) que também observaram que a adição de ágar pode melhorar as propriedades mecânicas das membranas de PVP. 


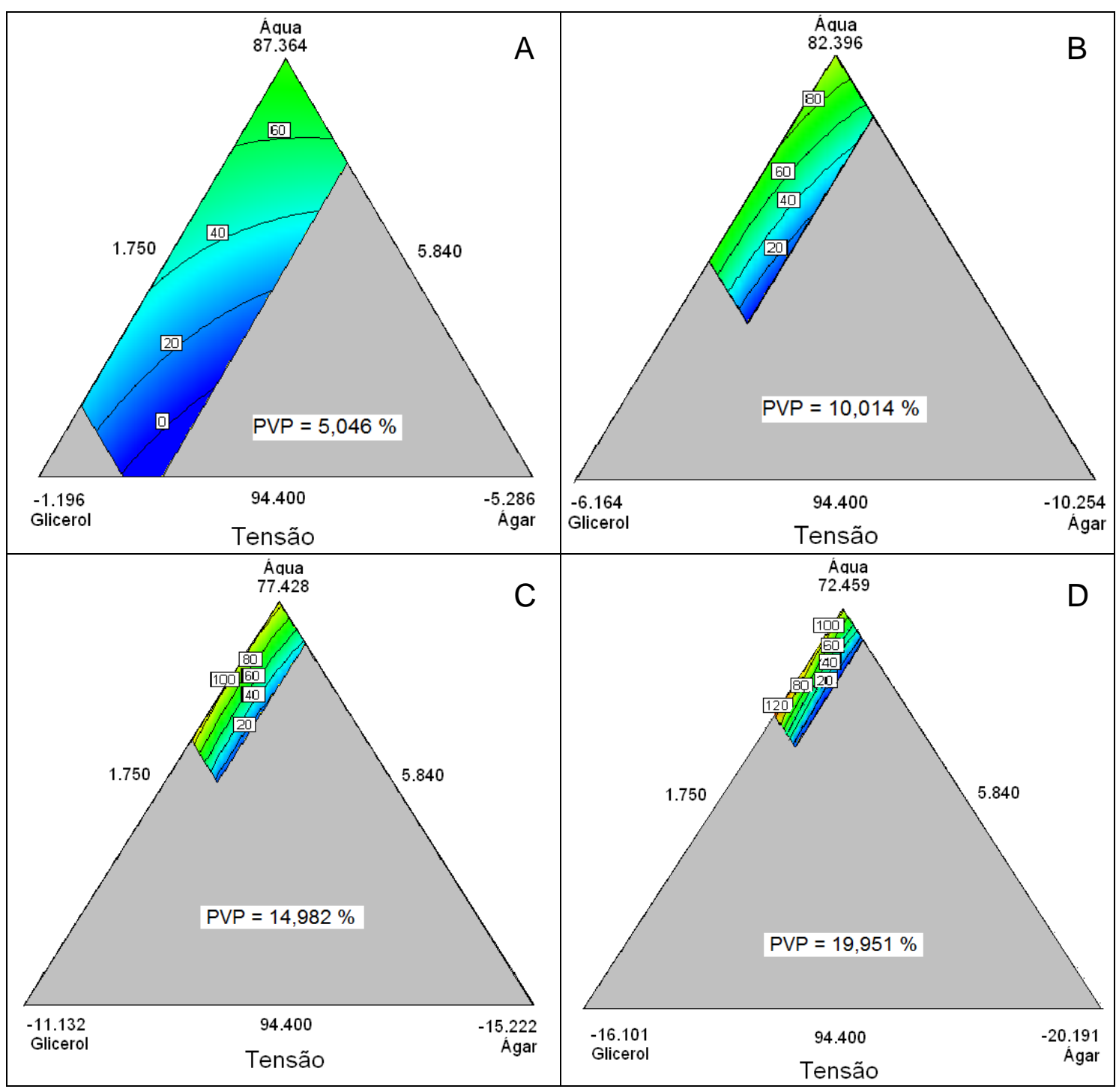

FIGURA 5.13 - Diagrama com as linhas de contorno para a resistência à tensão para o sistema PVP/glicerol/ ágar, com (A) 5\% de PVP, (B) 10\% de PVP, (C) 15\% PVP e (D) 20\% PVP.

\section{Sistema 3: PVA/KC/ágar}

A obtenção de um modelo matemático que pudesse explicar os dados obtidos para o sistema 3 também só foi possível removendo alguns pontos, representados pelos hidrogéis de ordem padrão 3, 7, 17, 19 e 20. As médias e os desvios-padrão dos resultados de resistência à tensão para o sistema 3 estão apresentados na FIG. 5.14, comparativamente aos resultados preditos pelo pela equação 5.9 e o erro do modelo. 


\section{Resistência à tração}

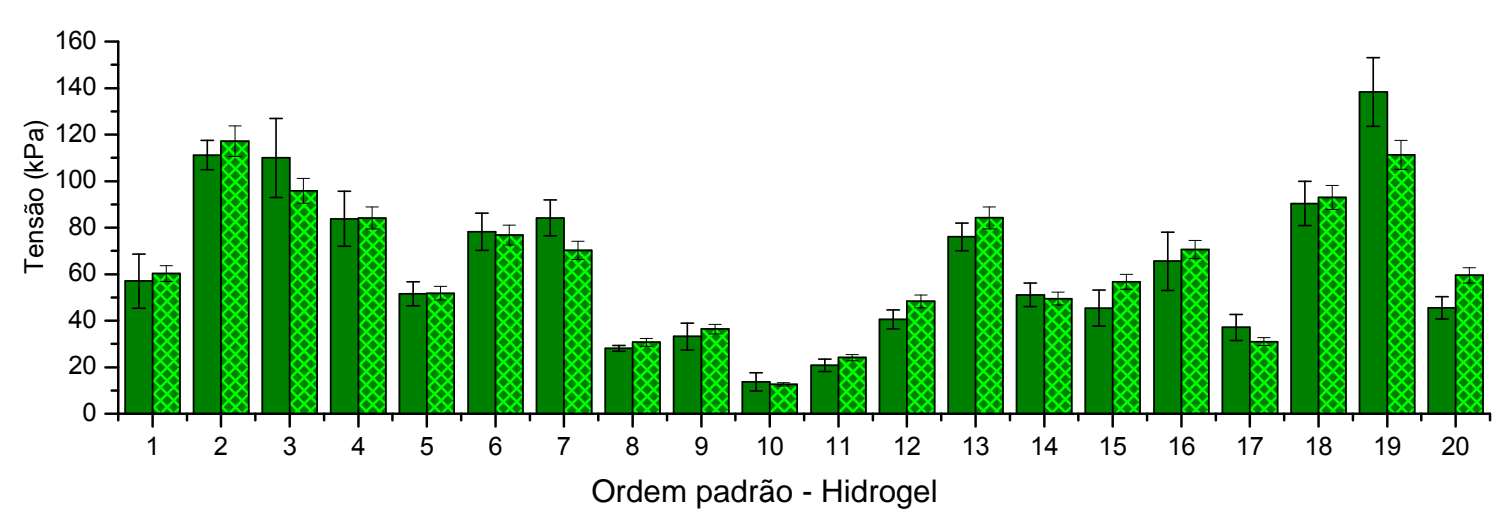

FIGURA 5.14 - Resultados de tensão na ruptura medidos experimentalmente e determinados pela regressão obtida.

A análise estatística dos resultados reduzidos, obtidos experimentalmente, está apresentada na TAB. C 3 (Apêndice C) e indica que o modelo representado pela equação 5.9 não apresenta evidência de falta de ajuste. Os resultados estão bem ajustados ao modelo obtido, com fator de correlação $R^{2}$ aj.= 95,41\%, indicando $95,41 \%$ das variabilidades de resistência à tração poderiam ser explicadas pelos modelos com $90 \%$ de confiabilidade se nenhum ponto tivesse sido eliminado da análise. Os resultados obtidos posteriormente, a partir da formulação otimizada, FIG. 5.31 apresentaram uma diferença significativa entre os resultados obtidos e os preditos pela regressão, ou seja, 37,6 kPa e 91,7 KPa. Por outro lado, entre os resultados apresentados na FIG. 5.14, não se observam muitas variações significantes.

Portanto, também não é possível afirmar que o modelo obtido para o sistema 3 apresenta significância estatística para resistência á tensão na ruptura.

A seguir está apresentada a regressão obtida e na FIG. 5.15 o diagrama, que representa a equação, para 5\%, 10\% e 15\% de PVA.

$$
\begin{array}{r}
\bar{\sigma}(\mathrm{kPa})=-10,08 \cdot x_{1}+3963,70 \cdot x_{2}-3018,98 \cdot x_{3}-0,18 \cdot x_{4}-37,87 \cdot x_{1} \cdot x_{2}+ \\
31,50 \cdot x_{1} \cdot x_{3}+0,16 \cdot x_{1} \cdot x_{4}-24,09 \cdot x_{2} \cdot x_{3}-39,75 \cdot x_{2} \cdot x_{4}+30,74 \cdot x_{3} \cdot x_{4}
\end{array}
$$

Sistema 3, sendo:

$\bar{\sigma}=$ Tensão na ruptura, concentrações $\%, x_{1}=[P V A], x_{2}=[K C], x_{3}=$ [ágar] e $x_{4}=$ [água] 
O modelo 5.9 indica que a $\mathrm{KC}$ e o ágar sozinhos são os componentes que influenciam fortemente os resultados de tensão, enquanto que o PVA sozinho e as interações entre os componentes influenciam mais fracamente o sistema.

A FIG. 5.15 que representa a regressão determinada para a blenda com 5 , 10 e $15 \%$ de PVA e sugere que a maior resistência possível é de ca. $100 \mathrm{KPa}$, para blenda com $15 \%$ de PVA.

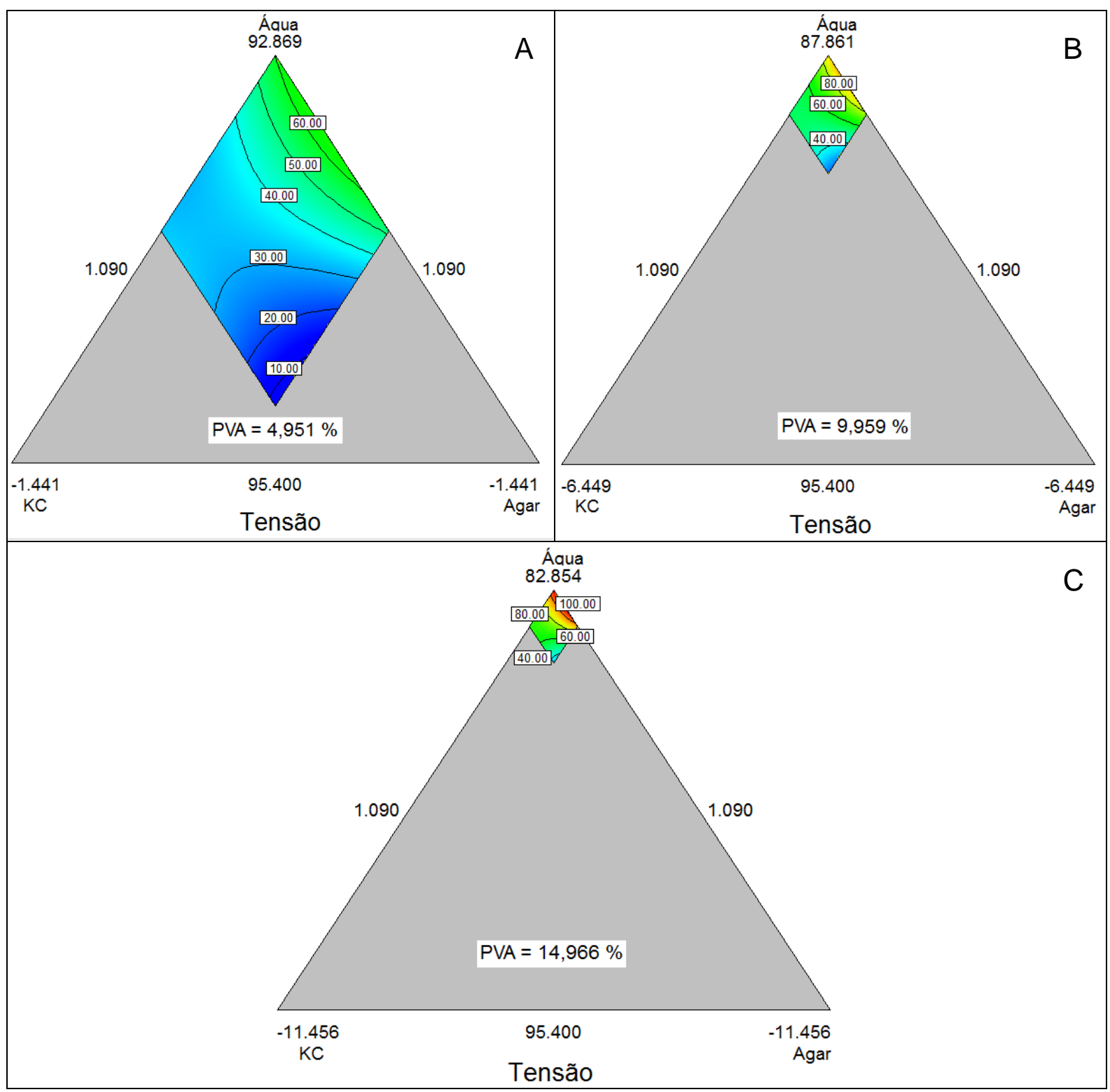

FIGURA 5.15 - Diagrama das linhas de contorno da superfície de resposta para tensão, no sistema PVA/ KC/ágar, com (A) 5\% PVA, (B) 10\% PVA e (C) 15\% PVA. 


\subsubsection{Deformação na tração}

\section{Sistemas 1 e 2: PVP/PEG/ágar e PVP/glicerol/ágar, respectivamente.}

Objetivando obter regressões com fator de correlação significativo, foram desconsiderados os resultados obtidos para os hidrogéis de ordem padrão: 1, 3, 9, 12, 18 e 19 do sistema 1 e ordem padrão: $1,5,8,10,11,13,14,16$ e 17 do sistema 2.

Os resultados de deformação na ruptura sob tensão, estão apresentados na FIG.5.16, comparativamente aos resultados preditos pelas regressões obtidas, que estão apresentadas nas equações 5.10 e 5.11 .

O coeficiente de determinação ( ${ }^{2}$ aj.) obtido para a equação 5.10 foi 96,39 $\%$ para o sistema 1 e $97,58 \%$ para o sistema 2. As análises estatísticas dos resultados reduzidos, obtidos experimentalmente estão apresentada nas TAB. D 1 e D 2 (Apêndice D).

Deformação na tração PVP/PEG/ágar - Obtido

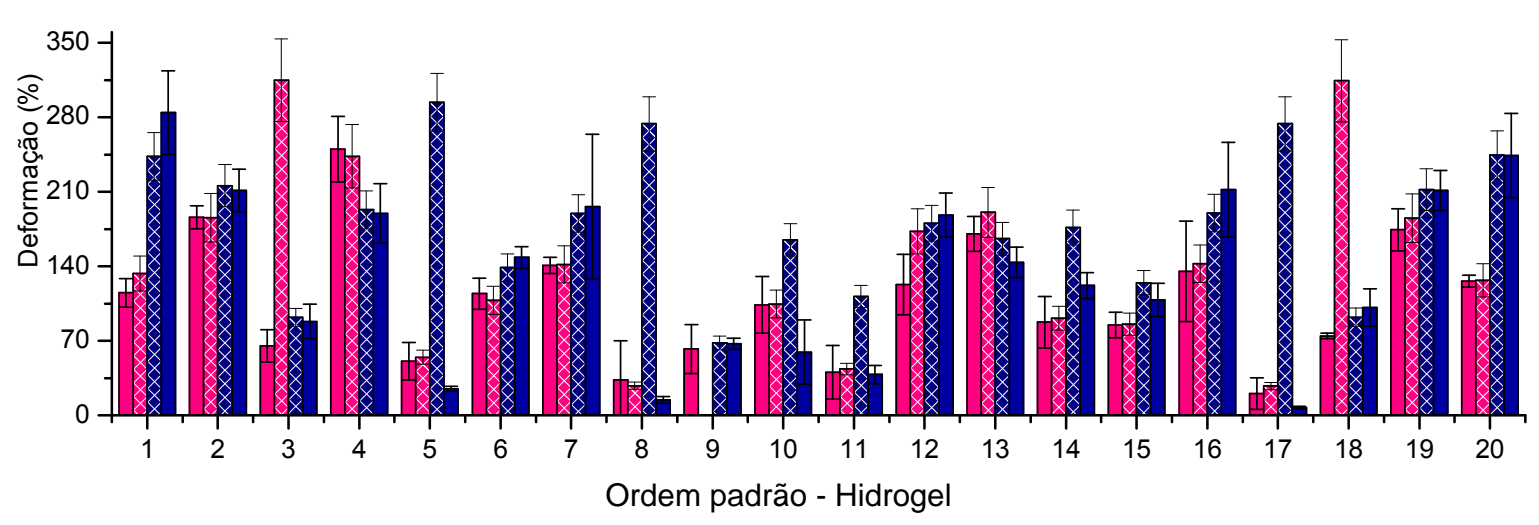

FIGURA 5.16 - Resultados da deformação na ruptura, obtidos experimentalmente e preditos para os hidrogéis dos sistemas 1 e 2 .

$$
\begin{aligned}
\bar{\varepsilon}_{R}(\%)= & 59,97 \cdot x_{1}+458,42 \cdot x_{2}+3634,05 \cdot x_{3}-0,81 \cdot x_{4}-3,18 \cdot x_{1} \cdot x_{2}-31,98 \cdot x_{1} \cdot x_{3} \\
& +0,79 \cdot x_{1} \cdot x_{4}-75,64 \cdot x_{2} \cdot x_{3}-4,24 \cdot x_{2} \cdot x_{3}-36,80 \cdot x_{3} \cdot x_{4}
\end{aligned}
$$

Sistema 1, sendo:

$\bar{\varepsilon}_{\mathrm{R}}=$ deformação na ruptura, concentrações $\%, x_{1}=[P V P], x_{2}=[P E G], x_{3}=$ [ágar $]$ e $x_{4}=$ [água] 


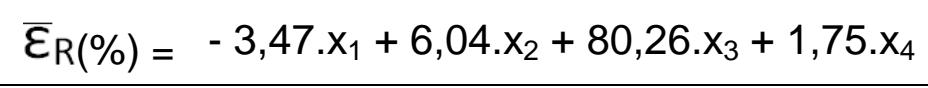

Sistema 2, sendo:

$\bar{\varepsilon}_{\mathrm{R}}=$ deformação na ruptura, concentrações \%, $\mathrm{x}_{1}=[\mathrm{PVP}], \mathrm{x}_{2}=$ [glicerol], $\mathrm{x}_{3}=$ [ágar] e $\mathrm{x}_{4}=$ [água]

Para testar as equações 5.10 e 5.11 foram utilizados os resultados obtidos posteriormente, nas formulações otimizadas, cujos dados podem ser visualizados na FIG. 5.32.

A deformação obtida para o hidrogel de PVP/PEG/ágar foi $44,1 \pm 14,6 \%$ e o valor predito $51,8 \pm 6,4 \%$. Para o hidrogel de PVP/glicerol/ágar, a deformação obtida foi $141,7 \pm 13,7 \%$, o que está em total desacordo com o resultado predito igual a $242,4 \pm 22,4 \%$.

Os resultados apresentados na FIG. 5.16 e os resultados obtidos nas formulações otimizadas indicam que a eliminação dos pontos do desenho do planejamento efetuado, assim como os dados terem sido originados das curvas de tensão $\mathrm{x}$ deformação de engenharia, comprometendo a qualidade dos resultados para determinação das regressões, não explicam os resultados gerais apresentados. Em função destes resultados, as linhas de contorno que é a projeção da superfície de resposta, assim como a interpretação das regressões obtidas para deformação na ruptura dos sistemas 1 e 2 não serão apresentadas.

\section{Sistema 3: PVA/KC/ágar}

A análise de variância da regressão obtida para os hidrogéis de PVA/KC/ágar indicou um modelo matemático incapaz de explicar todos os dados obtidos, por isso foram removidos os resultados obtidos para os hidrogéis de ordem padrão $3,13,14,18$ e 20 e repetida a análise. Os resultados obtidos estão apresentados na FIG. 5.17, comparativamente aos previstos pela equação 5.12 . 


\section{Deformação na tração}

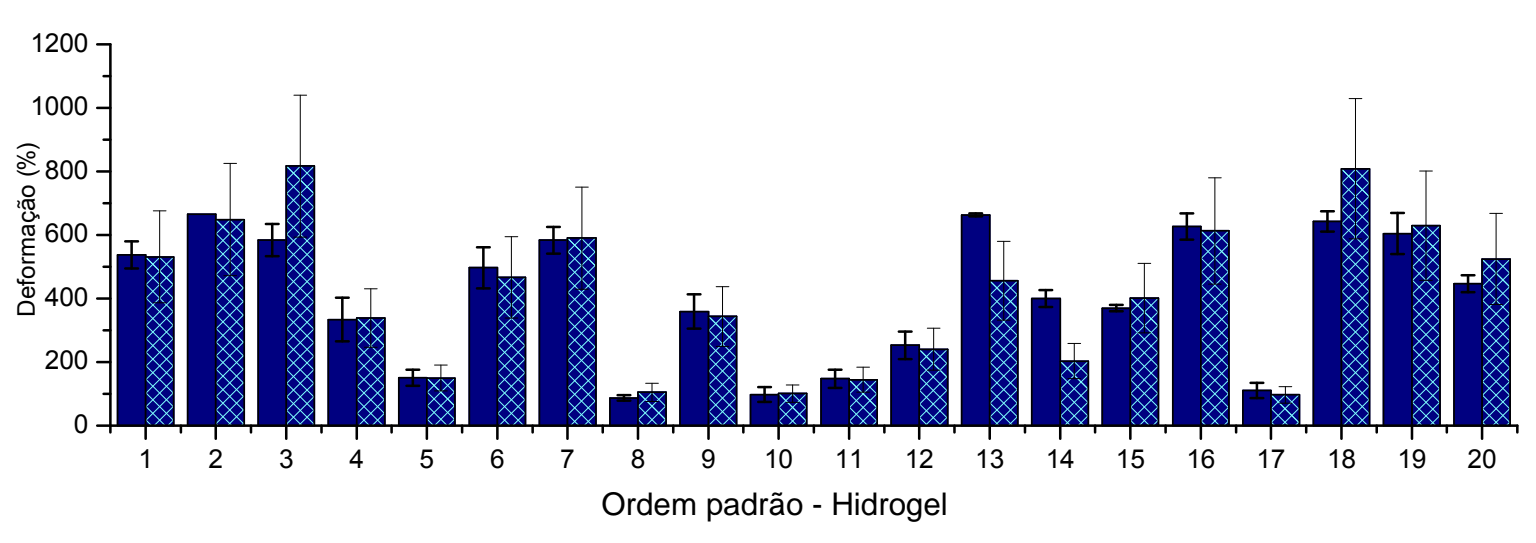

FIGURA 5.17 - Resultados de deformação na ruptura, obtidos nos ensaios de tração dos hidrogéis sintetizados, comparados aos resultados previstos pela regressão obtida.

A análise de variância da regressão obtida a partir dos resultados reduzidos está apresentada na TAB. D 3.1 no Apêndice D. A análise indicou que a regressão é significativa e está bem ajustada ao modelo quadrático, com coeficiente de determinação $R^{2}$ aj. $=98,34 \%$ indicando que praticamente todas as variâncias explicáveis poderiam ser descritas pela regressão obtida, caso não tivesse sido desprezado nenhum ponto do desenho experimental.

A regressão 5.12 representa a deformação na ruptura para o sistema PVA/KC/ágar e a FIG. 5.18 a superfície de contorno que representa a equação.

$$
\begin{aligned}
\bar{\varepsilon}_{\mathrm{R}(\%)=} & -207,65 \cdot x_{1}-27237,55 \cdot x_{2}+75811,17 \cdot x_{3}-6,08 \cdot x_{4}+281,82 \cdot x_{1} \cdot x_{2} \\
& -767,41 \cdot x_{1} \cdot x_{3}+3,13 \cdot x_{1} \cdot x_{4}-878,74 \cdot x_{2} \cdot x_{3}+279,82 \cdot x_{2} \cdot x_{4} \\
& -762,66 \cdot x_{3} \cdot x_{4}
\end{aligned}
$$

Sistema 3, sendo:

$\bar{\varepsilon}_{\mathrm{R}}=$ deformação na ruptura, concentrações $\%, x_{1}=[P V A], x_{2}=[K C], x_{3}=$ [ágar $]$ e $x_{4}=$ [água]

Com o resultado obtido posteriormente (FIG. 5.32) na formulação otimizada, foi possível testar a regressão, e o valor obtido para deformação na ruptura foi $230 \%$ e está em total desacordo com o resultado predito pela regressão, que foi de $379 \%$. Por outro lado, considerando o erro do modelo, os resultados apresentados na FIG. 5.17 não estão totalmente em desacordo com os 
resultados preditos, indicando que talvez a regressão apresente uma significância considerável.

A eq. 5.12 indica que a $K C$ e o ágar, sozinhos, apresentam uma forte contribuição nos resultados de deformação, seguida pelo PVA e por todas as interações, com exceção da interação PVA-água. As linhas de contorno das superfícies de contorno dos hidrogéis com 5, 10 e 15\% de PVA sugerem que a deformação pode chegar a $800 \%$ para o hidrogel com $15 \%$ de PVA, na ausência de ágar e com ca. $0,5 \%$ de KC.

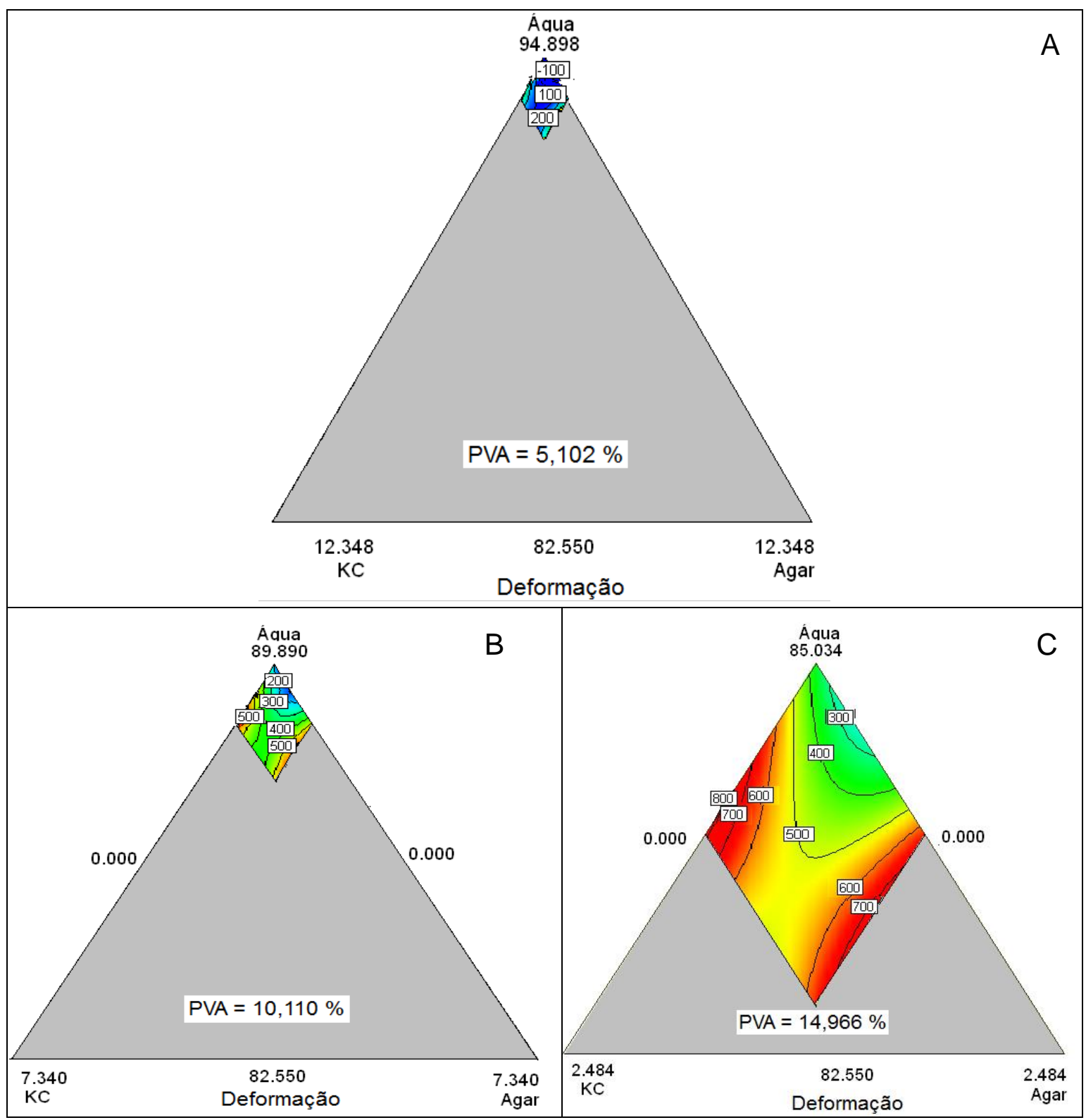

FIGURA 5.18 - Diagrama com as linhas de contorno da superfície de resposta do modelo obtido, para a deformação na ruptura dos hidrogéis com PVA/KC/ágar, sendo (A) 5\% PVA, (B) 10\% PVA e (C) 15\% PVA. 


\subsubsection{Módulo Elástico}

\section{Sistemas 1 e 2: PVP/PEG/ágar x PVP/glicerol/ágar, respectivamente.}

Para obtenção de modelos com coeficientes de determinação significantes, foram eliminados os resultados obtidos para os hidrogéis de ordem padrão: 2, 6, 9, 10, 13 e 19 do sistema 1 e ordem padrão: 2, 3, 4, 7, 10, 12, 14 e 18 do sistema 2. Os resultados de módulo elástico obtidos estão apresentados na FIG. 5.19 e estão comparados aos resultados previstos pelas regressões apresentadas pelas equações 5.13 e 5.14 .

Módulo elástico

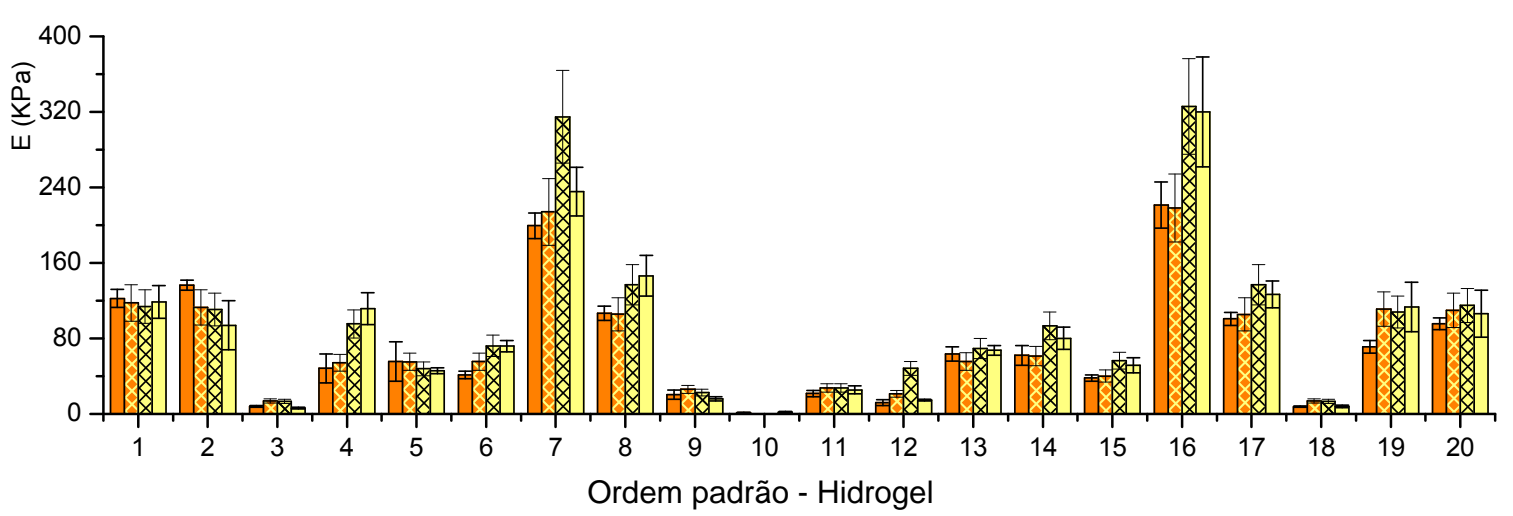

FIGURA 5.19 - Resultados de módulo elástico obtidos para os hidrogéis do sistema 1: PVP/PEG/ágar e sistema 2: PVP/glicerol/ágar.

As análises estatísticas das regressões obtidas a partir dos resultados reduzidos estão apresentadas nas TAB. E 1.1 e E 1.2 no Apêndice E. Os coeficientes de determinação obtidos para os sistemas 1 e 2 foram $R^{2} a j .=$ $92,88 \%$ e $95,59 \%$, respectivamente, sendo que somente o coeficiente do sistema 2 apresentou falta de ajuste, porém a mesmo é não significante.

As regressões obtidas para os sistemas 1 e 2 estão apresentadas nas equações 5.13 e 5.14, respectivamente, e os diagramas que as representam estão apresentados nas FIGs. 5.20 e 5.21.

$$
\begin{aligned}
\bar{E}(\mathrm{kPa})= & -11,79 \cdot \mathrm{x}_{1}+317,42 \cdot \mathrm{x}_{2}+2116,45 \cdot \mathrm{x}_{3}-0,12 \cdot \mathrm{x}_{4}-3,57 \cdot \mathrm{x}_{1} \cdot \mathrm{x}_{2} \\
& -17,7 \cdot \mathrm{x}_{1} \cdot \mathrm{x}_{3}+0,17 \cdot \mathrm{x}_{1} \cdot \mathrm{x}_{4}-34,21 \cdot \mathrm{x}_{2} \cdot \mathrm{x}_{3}-3,27 \cdot \mathrm{x}_{2} \cdot \mathrm{x}_{4}-20,96 \cdot \mathrm{x}_{3} \cdot \mathrm{x}_{4}
\end{aligned}
$$

Sistema 1, Sendo:

$\bar{E}=$ módulo elástico, concentrações $\%, x_{1}=[P V P], x_{2}=[P E G], x_{3}=[a ́ g a r] ~ e ~ x_{4}=$ [água $]$ 


$$
\begin{aligned}
\bar{E}(\mathrm{kPa})= & -19,07 \cdot \mathrm{x}_{1}+800,51 \cdot \mathrm{x}_{2}-2292,65 \cdot \mathrm{x}_{3}-0,33 \cdot \mathrm{x}_{4}-9,17 \cdot \mathrm{x}_{1} \cdot \mathrm{x}_{2} \\
& +29,69 \cdot \mathrm{x}_{1} \cdot \mathrm{x}_{3}+0,27 \cdot \mathrm{x}_{1} \cdot \mathrm{x}_{4}-7,68 \cdot \mathrm{x}_{2} \cdot \mathrm{x}_{3}-8,19 \cdot \mathrm{x}_{2} \cdot \mathrm{x}_{4}+23,99 \cdot \mathrm{x}_{3} \cdot \mathrm{x}_{4}
\end{aligned}
$$

Sistema 2, sendo:

$\bar{E}=$ módulo elástico, concentrações $\%, x_{1}=[P V P], x_{2}=$ [glicerol], $x_{3}=$ [ágar $]$ e $x_{4}=$ [água]

Analisando a FIG. 5.19 observa-se que os resultados preditos pelas regressões não apresentaram diferenças consideráveis em relação aos resultados obtidos, com exceção do hidrogel 7 do sistema 2. Entretanto não foi observada diferença significativa entre o resultado obtido e o predito pelo modelo para o hidrogel 16, que possui composição similar, sugerindo que o resultado médio obtido para o hidrogel 7 não é representativo.

Os modelos foram testados com os resultados obtidos posteriormente, nas formulações otimizadas, FIG. 5.33. O resultado obtido para o sistema 1 foi $28,7 \pm$ 2,8 KPa enquanto que o módulo elástico previsto pela regressão é 105,5 \pm 17,4 $\mathrm{KPa}$. Para o sistema 2 foi obtido $92,5 \pm 22,8 \mathrm{KPa}$. e o resultado previsto pela regressão foi $133,2 \pm 20,7 \mathrm{KPa}$, mostrando desconformidade entre os resultados obtidos para os dois sistemas, principalmente para o sistema 1. Entretanto, os resultados observados na FIG. 5.19 sugerem que as regressões apresentam significância, porém não se pode indicar qual o seu nível.

As regressões e as linhas de contorno das superfícies de resposta obtidas para os sistemas 1 e 2, FIG. 5.20 e 5.21, indicam que o ágar sozinho apresenta uma forte contribuição nos resultados do módulo elástico, seguido pelo PEG e glicerol. Para os dois sistemas, pode-se observar que o resultado do módulo elástico é fracamente influenciado pelo PVP sozinho assim como pelas interações entre os componentes. Observa-se que a influência do glicerol é bem maior quando comparada à do PEG. 


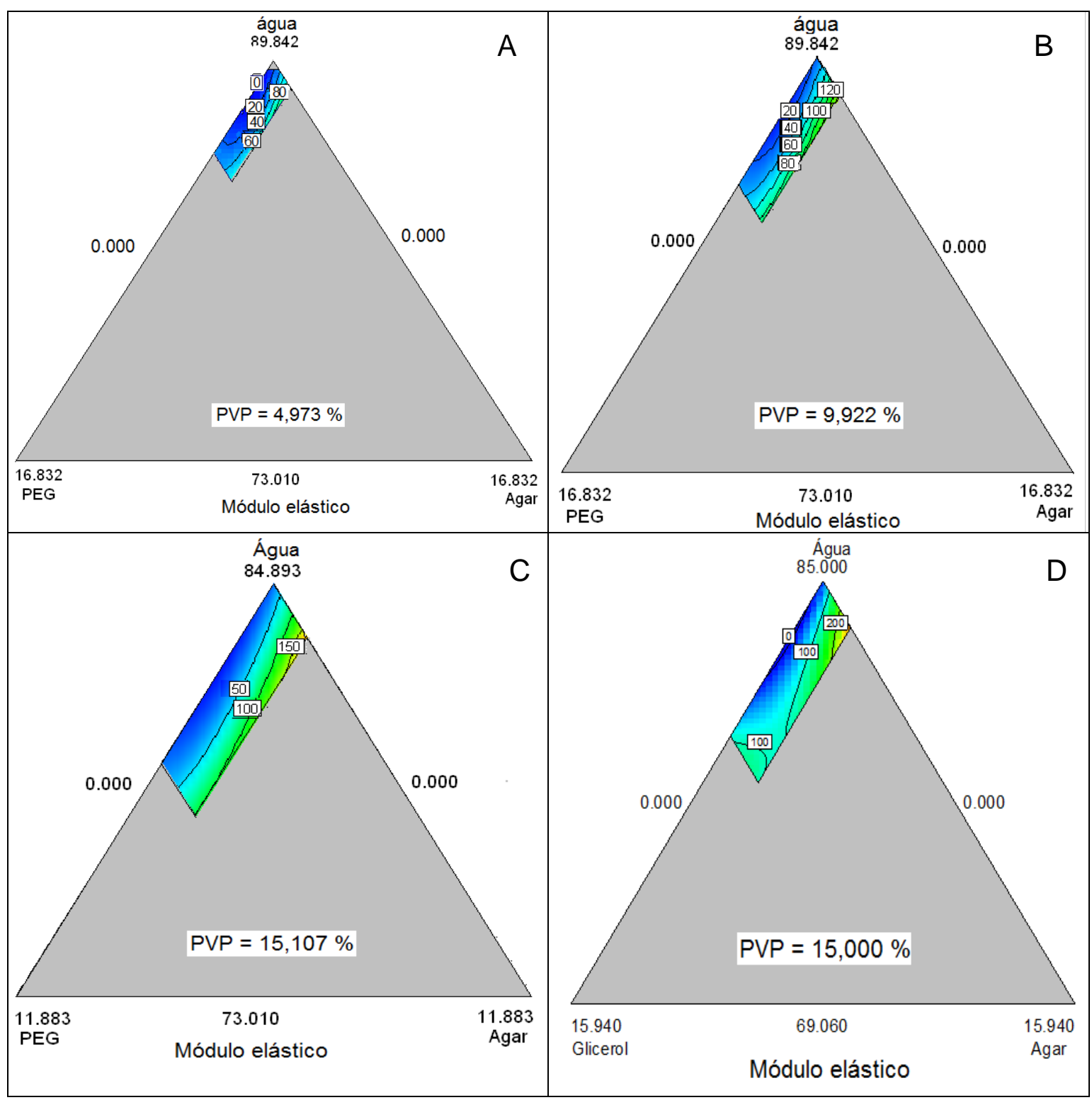

FIGURA 5.20 - Diagrama com as linhas de contorno para módulo elástico do sistema PVP/PEG/ágar, sendo (A) 5\% de PVP, (B) 10\% de PVP e (C) 15\% PVP. 


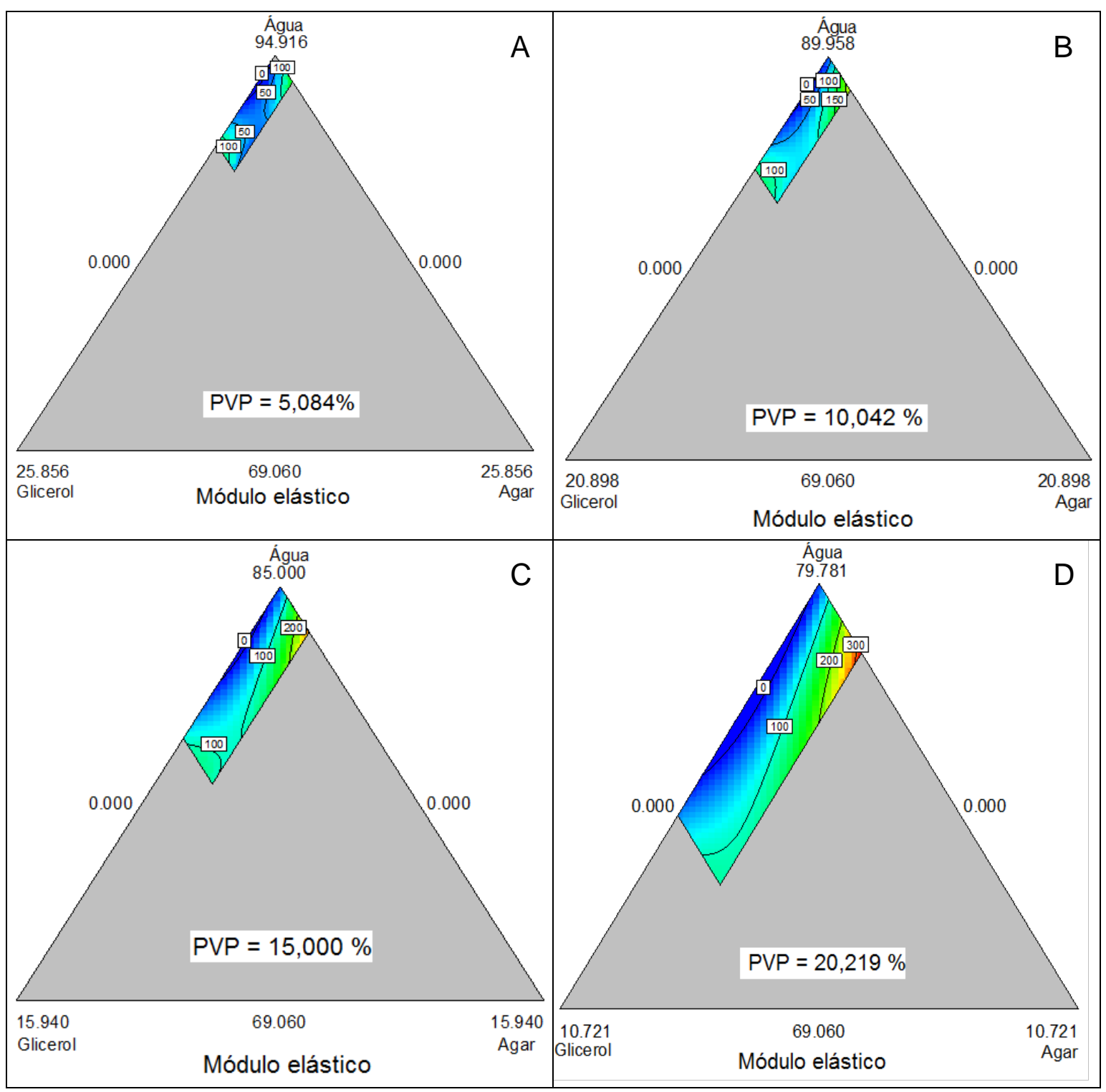

FIGURA 5.21 - Diagrama com as linhas de contorno para módulo elástico do sistema PVP/glicerol/gar, sendo (A) 5\% de PVP, (B) 10\% de PVP e (C) 15\% PVP.

\section{Sistema 3: PVA/KC/ágar}

Um modelo estatístico que pudesse explicar melhor os resultados de módulo elástico foi obtido após remover os pontos obtidos para os hidrogéis de ordem padrão 3 e 19. Os resultados obtidos estão apresentados na FIG. 5.22, comparativamente aos resultados calculados com a equação 5.15 . 
Módulo elástico

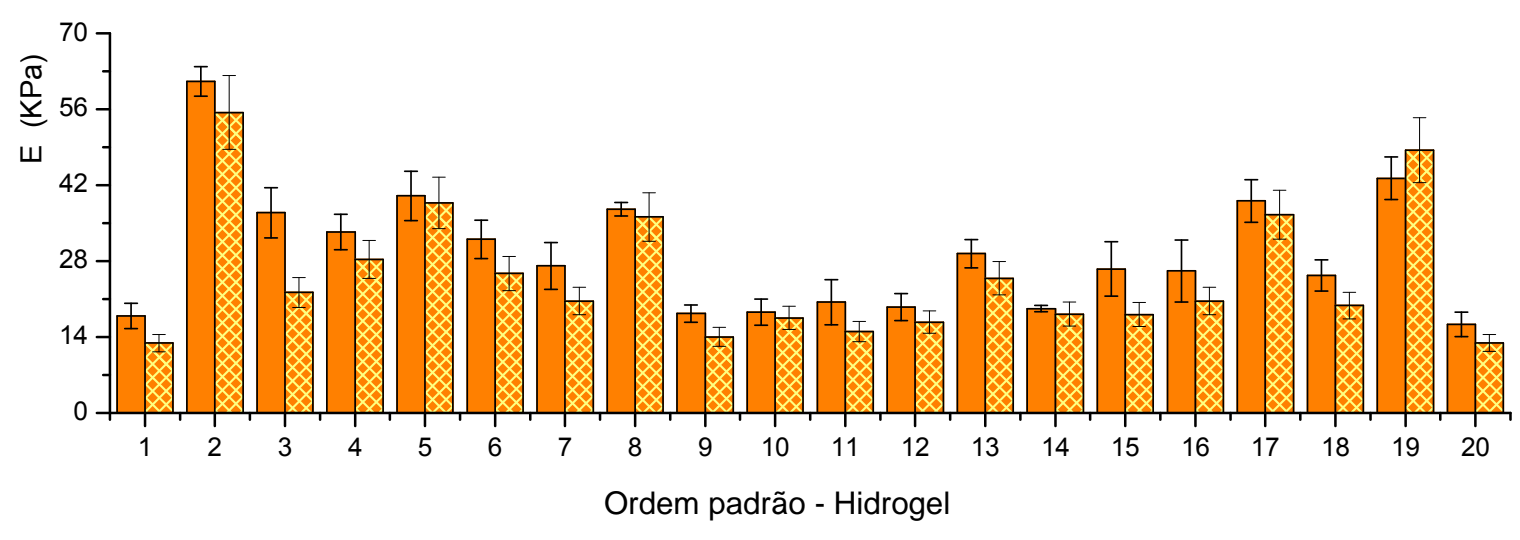

FIGURA 5.22 - Resultados de módulo elástico obtidos para os hidrogéis do sistema 3: PVA/KC/ágar, comparados com os resultados obtidos a partir da equação 5.15 .

A análise estatística da regressão, excluindo os pontos 3 e 19, está apresentada na TAB. E 3 no Apêndice $E$.

A ANOVA apresentada na tabela E 3.1 indica que os resultados estão bem ajustados ao do modelo predito, com fator de determinação $R^{2} a j .=97,47 \%$ e a Fig. 5.22 mostra que os resultados preditos pelo modelo não apresentam diferenças significativas em relação aos resultados obtidos, sendo a diferença observada para o hidrogel 18 pouco representativa, tendo em vista que o resultado obtido para o hidrogel 3 que apresenta a mesma composição.

A regressão 5.15 representa o módulo elástico do sistema PVA/KC/ágar.

$$
\begin{aligned}
\bar{E}(\mathrm{kPa})= & +33,53 \cdot \mathrm{x}_{1}+4146,44 \cdot \mathrm{x}_{2}-3699,11 \cdot \mathrm{x}_{3}+0,72 \cdot \mathrm{x}_{4}-40,38 \cdot \mathrm{x}_{1} \cdot \mathrm{x}_{2} \\
& +37,61 \cdot \mathrm{x}_{1} \cdot \mathrm{x}_{3}-0,43 \cdot \mathrm{x}_{1} \cdot \mathrm{x}_{4}+15,32 \cdot \mathrm{x}_{2} \cdot \mathrm{x}_{3}-42,16 \cdot \mathrm{x}_{2} \cdot \mathrm{x}_{4}+37,34 \cdot \mathrm{x}_{3} \cdot \mathrm{x}_{4}
\end{aligned}
$$

Sistema 3, sendo:

$\bar{E}$ = módulo elástico, concentrações $\%, x_{1}=[P V A], x_{2}=[K C], x_{3}=$ [ágar] e $x_{4}=$ [água $]$

Com o resultado obtido posteriormente, para a formulação otimizada (FIG. 5.33), foi possível testar a regressão, e o resultado obtido foi $25,9 \pm 0,3 \mathrm{KPa}$, enquanto que o predito pela regressão foi $32,1 \pm 0,6 \mathrm{KPa}$. Os resultados obtidos sugerem que a regressão obtida apresenta significância, entretanto o módulo de elasticidade foi calculado a partir da curva de tensão $\mathrm{x}$ deformação de engenharia 
e a Lei de Hooke não é válida para materiais que apresentam grandes deformações, como foi o caso dos hidrogéis de PVA, uma vez que a curva tensão-deformação de engenharia não fornece boas indicações das características de tensão dos materiais.

\subsubsection{Resistência à perfuração}

Os valores apresentados devem ser interpretados em módulo, uma vez que o sinal negativo indica que os corpos de prova foram submetidos a uma força oposta à utilizada nos ensaios de tração.

\section{Sistema 1 e 2: PVP/PEG/ágar x PVP/glicerol/ágar, respectivamente.}

Para obtenção de um modelo que melhor se adequasse aos resultados obtidos para o sistema 1, foram eliminados da análise os pontos referentes aos hidrogéis de ordem padrão 10,12, 15 e 18, ao contrário do sistema 2, do qual não foi necessário desconsiderar nenhum ponto. Na FIG. 5.23 estão apresentados os resultados obtidos comparados aos resultados preditos pelas equações $5.16 \mathrm{e}$ 5.17 .

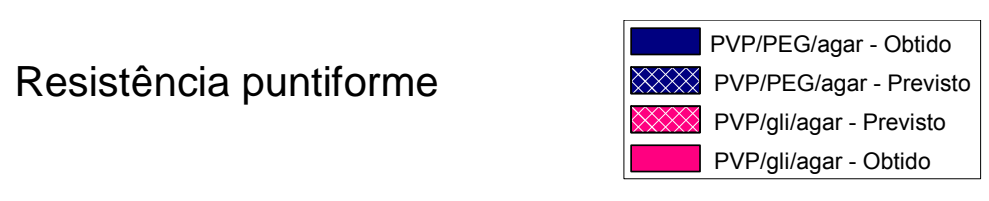

Ordem padrão - Hidrogel

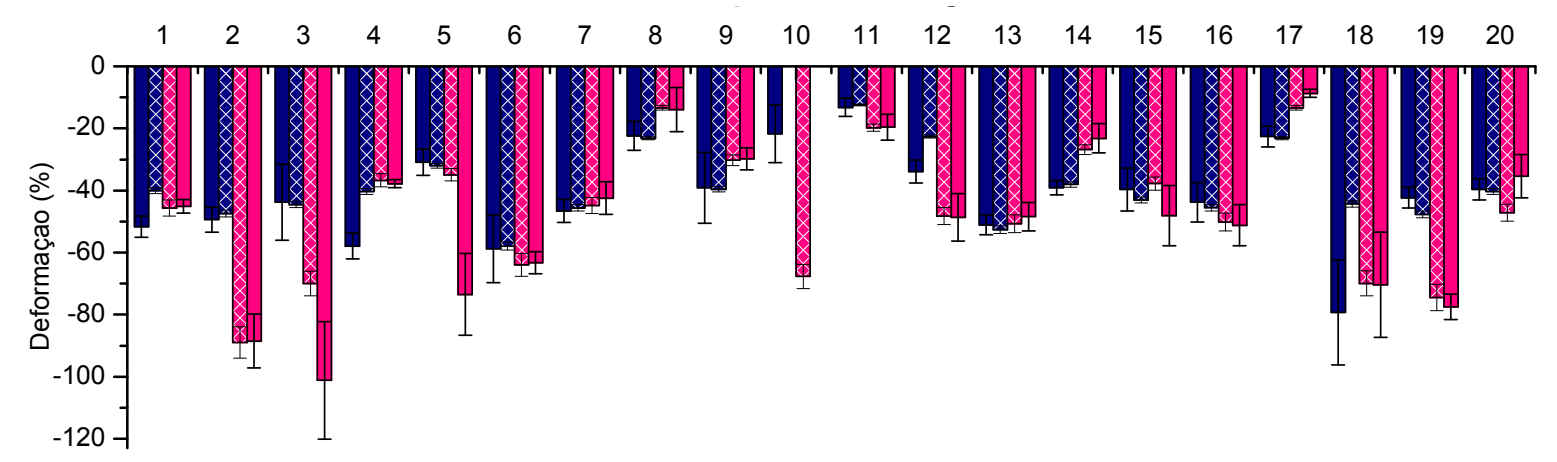

FIGURA 5.23 - Resultados da força puntiforme obtida na perfuração das membranas de hidrogel de PVP/PEG/ágar e PVP/glicerol/ágar.

Os parâmetros das regressões obtidas com os dados reduzidos resultaram em um modelo linear com $R^{2}$ aj. = 95,27\% para o sistema 1 e um modelo quadrático com $R^{2}$ aj. $=96,05 \%$ para o sistema 2 , sendo que somente o segundo apresentou falta de ajuste, porém considerado não significante. $O$ teste 
F indicou que os modelos são significantes, com $90 \%$ de confiabilidade, entretanto, considerando a eliminação de alguns pontos para o sistema 1, não se pode afirmar que este índice seja válido para o sistema PVP/PEG/ágar. As análises estatísticas dos resultados considerados estão apresentadas nas TAB. F 1 e $F 2$ no Apêndice $F$.

Os modelos foram testados com os resultados obtidos posterioremente, a partir das formulações otimizadas (FIG. 5.34). Para o hidrogel de PVP/PEG/ágar o resultado médio de força puntiforme obtido foi $1,6 \pm 0,4 \mathrm{~N}$ e o resultado predito foi $2,1 \pm 0,2 \mathrm{~N}$, enquanto que para o hidrogel de PVP/glicerol/ágar o resultado obtido foi $2,0 \pm 0,16 \mathrm{~N}$ e o resultado predito $2,7 \pm 0,3 \mathrm{~N}$.

Considerando os resultados observados na FIG. 5.24 e a confiabilidade de $90 \%$ para o modelo do sistema 2 , a diferença observada no resultado obtido na formulação otimizada possivelmente esteja dentro dos $10 \%$ esperado. Quanto ao sistema 1, os resultados obtidos parecem compatíveis, porém devem ser encarados com alguma desconfiança.

As equações 5.16 e 5.17 apresentam as regressões obtidas e nas FIG. 5.24 e 5.25 estão apresentadas as linhas de contorno que representam os respectivos modelos, para $5 \%, 10 \%$ e $15 \%$ de PVP.

$$
\bar{F}_{p}(N)=-0,07 \cdot x_{1}+0,04 \cdot x_{2}-1,47 \cdot x_{3}+0,005 \cdot x_{4}
$$

Sistema 1, sendo:

$\overline{F_{\mathrm{p}}}=$ Força puntiforme, concentrações $\%, \mathrm{x}_{1}=[\mathrm{PVP}], \mathrm{x}_{2}=[\mathrm{PEG}], \mathrm{x}_{3}=$ [ágar $]$ e $\mathrm{x}_{4}=$ [água $]$

$$
\begin{aligned}
\bar{F}_{p}(N)= & 0,35 \cdot x_{1}-6,62 \cdot x_{2}+65,84 \cdot x_{3}+0,005 \cdot x_{4}+0,07 \cdot x_{1} \cdot x_{2}-0,79 \cdot x_{1} \cdot x_{3} \\
& -0,005 \cdot x_{1} \cdot x_{4}-0,44 \cdot x_{2} \cdot x_{3}+0,07 \cdot x_{2} \cdot x_{4}-0,67 \cdot x_{3} \cdot x_{4}
\end{aligned}
$$

Sistema 2, sendo:

$\bar{F}_{\bar{p}}=$ Força puntiforme, concentrações $\%, x_{1}=[P V P], x_{2}=$ [glicerol], $x_{3}=$ [ágar] e $x_{4}=$ [água $]$

O modelo linear, equação 5.16, sugere que as respostas são diretamente proporcionais aos ingredientes, não há interações entre os componentes da mistura, e o ágar é o componente que contribui mais significantemente para a resposta, assim como foi observado para os resultados de tensão na ruptura (Eq. 5.7). 
Para o sistema 2 (PVP/glicerol/ágar) a equação 5.17, do modelo quadrático, também indica que o ágar sozinho é o componente que mais contribui para a resposta, seguido pelo glicerol. No entanto, para esse sistema observamse pequenas interações entre os componentes da mistura, sendo a maior delas entre PVP - ágar, cuja contribuição é pouco maior que a do PVP sozinho.

As linhas de contorno que representam as superfícies de resposta dos dois sistemas (PVP/PEG/ágar e PVP/glicero/ágar), ambos com 5\%, 10\%, 15\% e 20\% PVP estão apresentadas nas FIGs. 5.24 e 5.25 respectivamente.

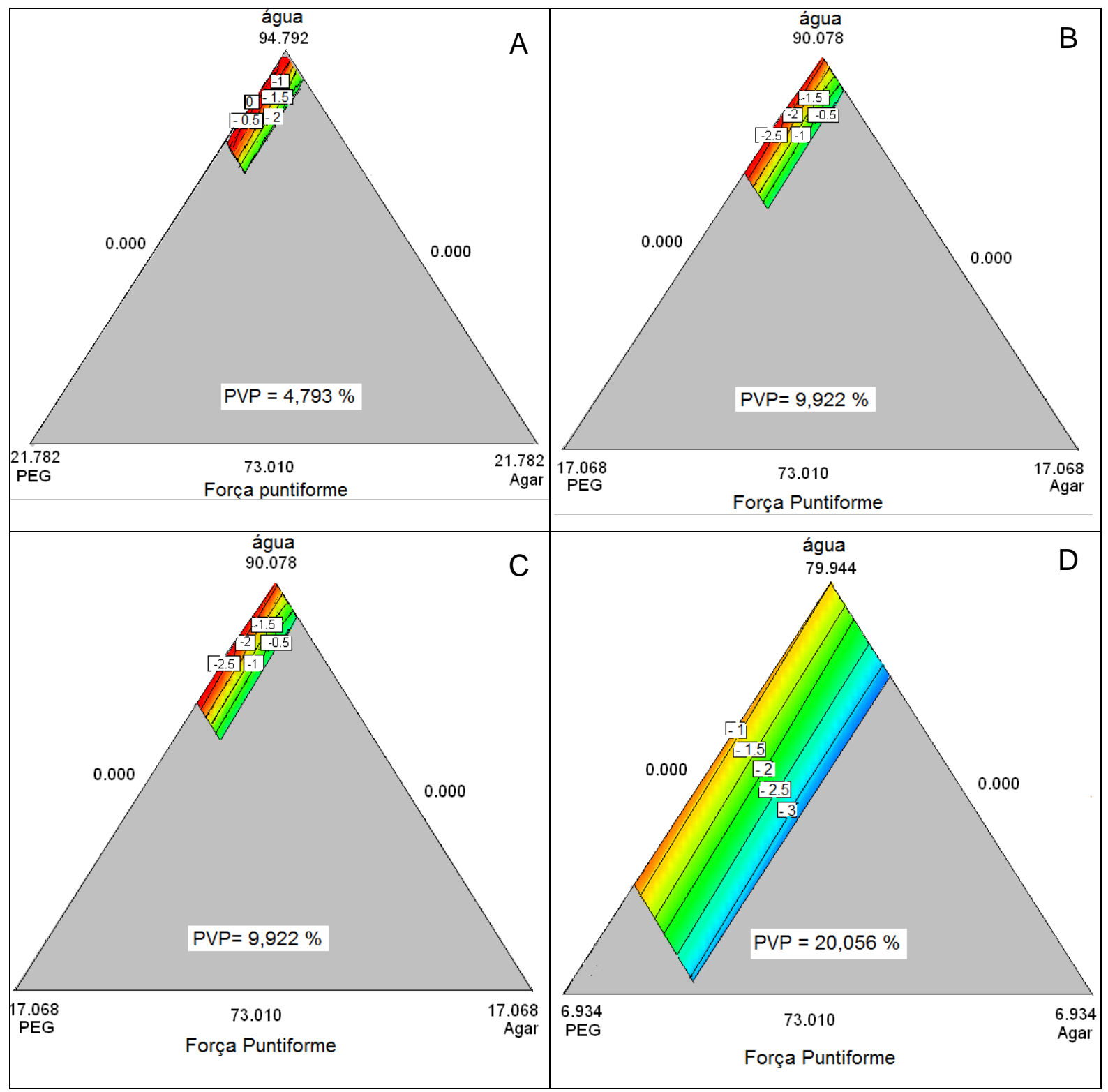

FIGURA 5.24 - Superfícies de contorno geradas pelas regressões 6.16 e 6.17 que representam o sistema PVP/PEG/ágar com (A) 5\% PVP, (B) 10\% de PVP, (C) 15\% PVP e (D) $20 \%$ PVP. 


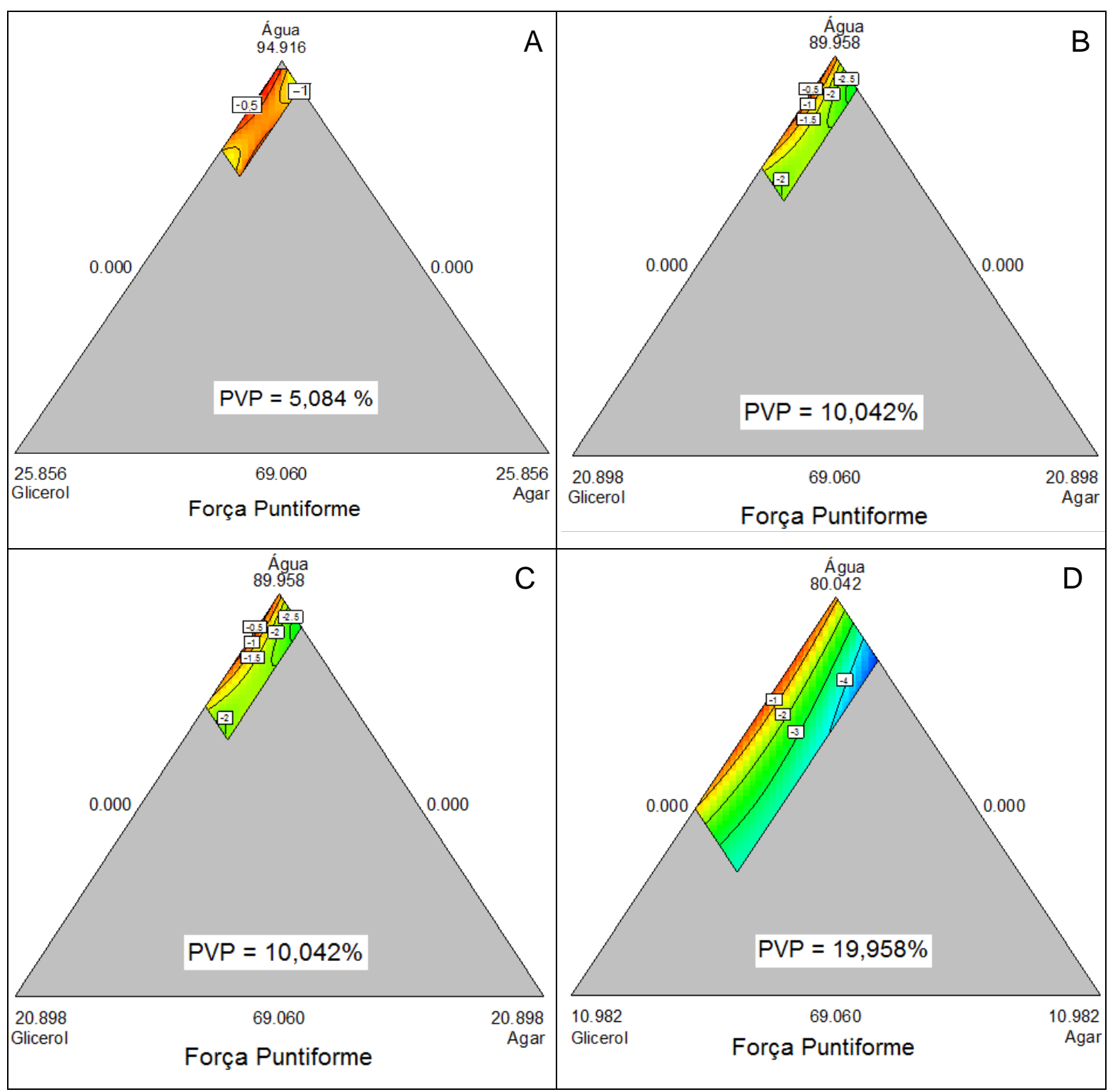

FIGURA 5.25 - Superfícies de contorno geradas pelas regressões 6.16 e 6.17 que representam o sistema PVP/PEG/ágar com (A) $5 \%$ PVP, (B) 10\% de PVP, (C) $15 \%$ PVP e (D) $20 \%$ PVP.

\section{Sistema 3: PVA/KC/ágar}

A análise de todos os dados não resultou numa regressão bem ajustada. Por isso foram eliminados os pontos representados pelos hidrogéis de ordem padrão 2, 10, 12 e 17. Os resultados obtidos experimentalmente estão apresentados na FIG. 5.26, comparados aos resultados preditos pela equação 5.18 obtida. 


\section{Resistência puntiforme}

Ordem padrão - Hidrogel

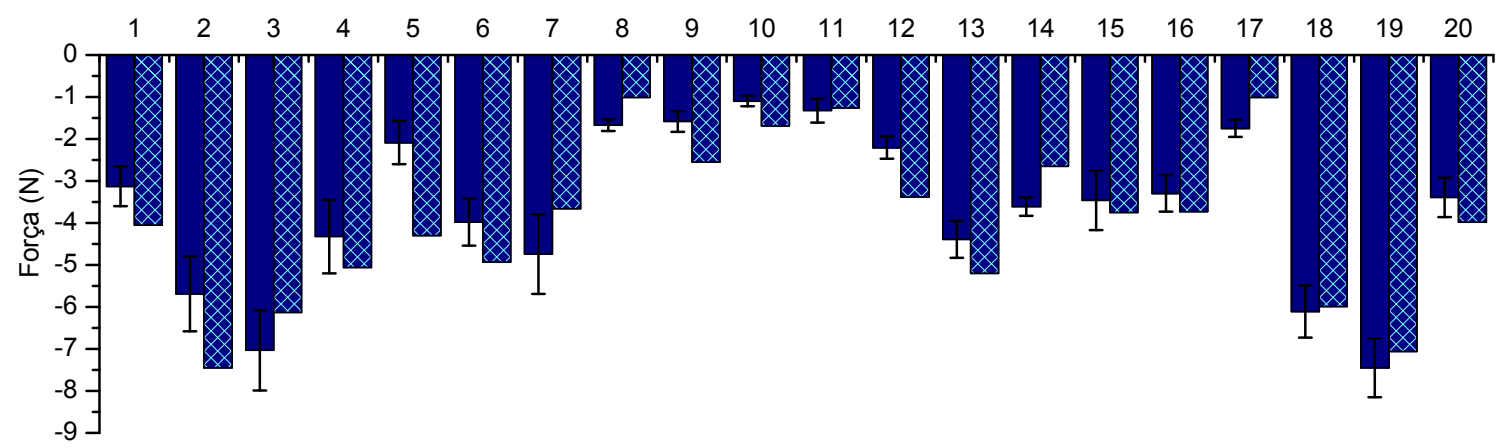

FIGURA 5.26 - Resultados de resistência puntiforme para os hidrogéis de PVA/KC/ágar.

A progressão obtida com os dados reduzidos é representada pela Eq. 5.18; o coeficiente de determinação obtido foi $R^{2} a j=83,56 \%$. A análise estatística da regressão obtida com os resultados reduzidos está apresentada na TAB. F 3 no Apêndice $F$.

A seguir está apresentada a regressão 5.18 e na FIG. 5.27, a superfície de contorno que representa o modelo matemático para hidrogéis com 5\%,10\% e $15 \%$ de PVA.

$$
\overline{F_{p}}(N)=-0,24 \cdot x_{1}-3,27 \cdot x_{2}-0,96 \cdot x_{3}+0,01 \cdot x_{4}
$$

Sistema 3, sendo:

$\bar{F}_{\bar{p}}=$ Força puntiforme, concentrações $\%, x_{1}=[P V A], x_{2}=[K C], x_{3}=$ [ágar] e $x_{4}=$ [água $]$

A equação 5.18 sugere que a $\mathrm{KC}$ é o componente que mais influencia no resultado de perfuração, diferentemente dos hidrogéis de PVP, dos sistemas $1 \mathrm{e}$ 2, cuja maior influência é do ágar.

O modelo foi testado com o resultado obtido posteriormete, FIG.5.34, a partir da formulação otimizada, e o valor da força obtido para o hidrogel sintetizado foi 2,5 $\pm 0,5 \mathrm{~N}$ enquanto que o valor predito pelo modelo é $5,5 \pm 0,8 \mathrm{~N}$ sugerindo que os resultados não são compatíveis. Apesar dos resultados observados na FIG. 5.26, a regressão deve ser vista com cautela, tendo em vista os pontos desconsiderados 
na análise e a diferença observada entre $\mathrm{o}$ resultado obtido e predito para a fórmula otimizada.

Na FIG. 5.27 estão apresentados os diagramas com as linhas de contorno que representam a regressão 5.18 , para os hidrogéis com $5 \%, 10 \%$ e $15 \%$ de PVA. Ela ilustra claramente a influência da KC no sistema.

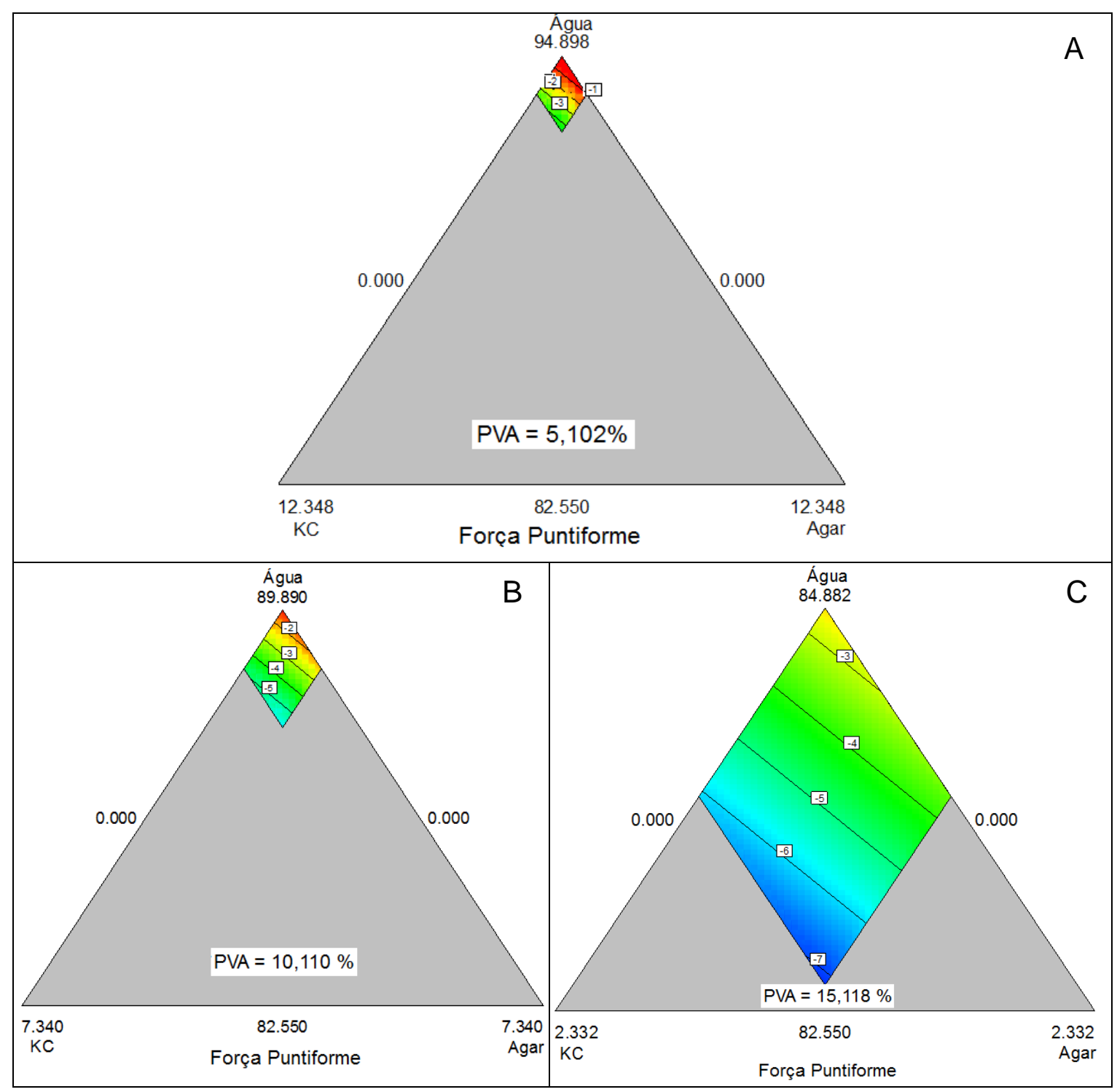

FIGURA 5.27 - Linhas de contorno da superfície de resposta para força puntiforme dos hidrogéis de PVA/ KC/ ágar para (A) 5\% PVA, (B) 10\% PVA e (C) $15 \%$ PVA. 


\subsubsection{Deformação na perfuração}

\section{Sistema 1 e 2: PVP/PEG/ágar x PVP/glicerol/ágar}

Depois de eliminados os pontos 1, 4, 10 e 18 do sistema 1 e os pontos 3, 5, 7, 10,17 e 20 do sistema 2, para obtenção de um modelo com coeficiente de determinação significante, as ANOVAs dos modelos 5.19 e 5.20, apresentadas nas TAB. G.1.1 e G.2.1 do apêndice $G$, indicaram que o modelo quadrático é o que melhor se ajusta aos dados experimentais dos dois sistemas. Nos dois casos, as análises indicaram que os resultados estão bem ajustados aos modelos preditos, com $R^{2}$ aj.= 94,88\% para o sistema 1 e $R^{2}$ aj.= 93,22\% para o sistema 2 e, portanto, praticamente todas as variabilidades da deformação na perfuração poderiam ser explicadas pelos modelos, com nível de confiabilidade de $90 \%$, se não tivesse sido desconsiderado nenhum dos pontos.

Os resultados de deformação das membranas quando submetidas à ação de uma força puntiforme estão apresentados na FIG. 5.27, em comparação com os resultados previstos pelas equações 5.19 e 5.20 .

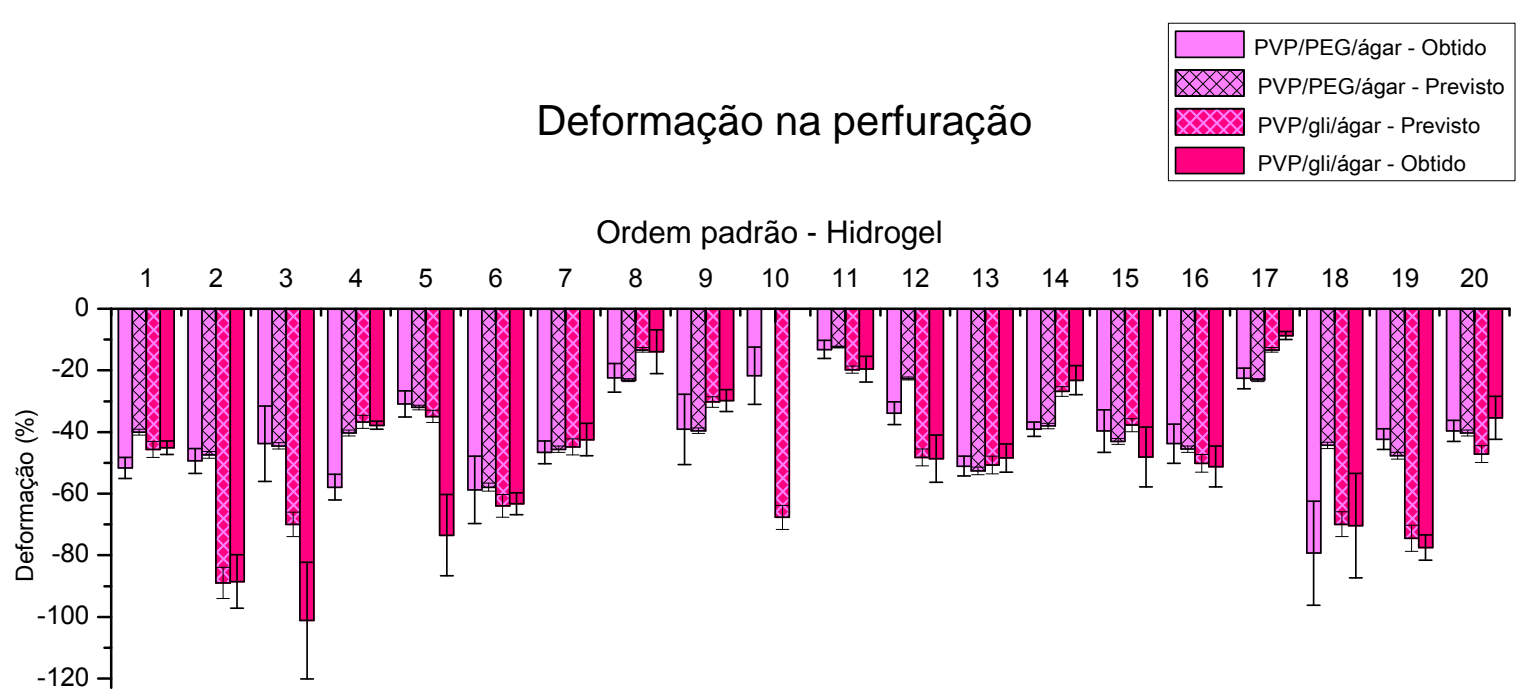

FIGURA 5.28 - Resultados de deformação na perfuração obtidos para os hidrogéis de PVP/PEG/ágar e PVP/glicerol/ágar, comparados com os resultados preditos pelos modelos determinados. 
Abaixo estão apresentadas equações 5.19 e 5.20 obtidas:

$$
\begin{aligned}
\bar{\sigma}_{\mathrm{p}}(\mathrm{kPa})= & -3,12 \cdot \mathrm{x}_{1}+46,02 \cdot \mathrm{x}_{2}+1631,31 \cdot \mathrm{x}_{3}+0,27 \cdot \mathrm{x}_{4}-0,42 \cdot \mathrm{x}_{1} \cdot \mathrm{x}_{2} \\
& -15,63 \cdot \mathrm{x}_{1} \cdot \mathrm{x}_{3}+0,002 \cdot \mathrm{x}_{1} \cdot \mathrm{x}_{4}-17 \cdot \mathrm{x}_{2} \cdot \mathrm{x}_{3}-0,51 \cdot \mathrm{x}_{2} \cdot \mathrm{x}_{4}-16,86 \cdot \mathrm{x}_{3} \cdot \mathrm{x}_{4}
\end{aligned}
$$

Sistema 1, sendo:

$\bar{\sigma}_{\mathrm{p}}=$ Deformação na perfuração, concentrações $\%, x_{1}=[\mathrm{PVP}], \mathrm{x}_{2}=[\mathrm{PEG}], \mathrm{x}_{3}=$ [ágar $]$ e $\mathrm{x}_{4}=$ [água $]$

$$
\begin{aligned}
\bar{\sigma}_{p}(\mathrm{kPa})= & -14,56 \cdot x_{1}+260,06 \cdot x_{2}-1814,08 \cdot x_{3}-0,52 \cdot x_{4}-2,75 \cdot x_{1} \cdot x_{2} \\
& +17,61 \cdot x_{1} \cdot x_{3}+0,19 \cdot x_{1} \cdot x_{4}+16,83 \cdot x_{2} \cdot x_{3}-2,80 \cdot x_{2} \cdot x_{4}+ \\
& 18,62 \cdot x_{3} \cdot x_{4}
\end{aligned}
$$

Sistema 2, sendo:

$\bar{\sigma}_{\mathrm{p}}=$ Deformação na perfuração, concentrações $\%, x_{1}=[\mathrm{PVP}], \mathrm{x}_{2}=$ [glicerol $], \mathrm{x}_{3}=$ [ágar $] \mathrm{e}$ $\mathrm{x}_{4}=$ [água]

As regressões obtidas para os dois sistemas sugerem interações entre os dois sistemas, no entanto, o ágar sozinho é o componente que mais contribui para os resultados de deformação na perfuração.

Para testar os modelos, foram considerados os resultados obtidos posteriormente, FIG. 5.35, a partir das formulações otimizadas. Os resultados de deformação na perfuração obtidos para o hidrogel de PVP/PEG/ágar sintetizado foi $18,4 \pm 5,8 \%$ enquanto que o valor predito pelo modelo é $29 \pm 0,7 \%$. Para o hidrogel de PVP/glicerol/ágar o resultado obtido foi $40,1 \pm 7,5 \%$ e o predito $35 \pm 2,0 \%$.

As diferenças observadas na FIG. 5.28, entre os resultados obtidos experimentalmente, os preditos pela regressão e os obtidos nas formulações otimizadas sugerem que as regressões devem ser vistas com cautela.

A análise das regressões e das linhas de contorno que representam os dois sistemas para 5, 10 e 15\% de PVP, FIGs. 5,29 e 5.30 indicam que é possível obter hidrogéis com maiores deformações para hidrogéis com glicerol na sua composição que com hidrogéis com a mesma concentração de PVP e contendo PEG em lugar do glicerol. 


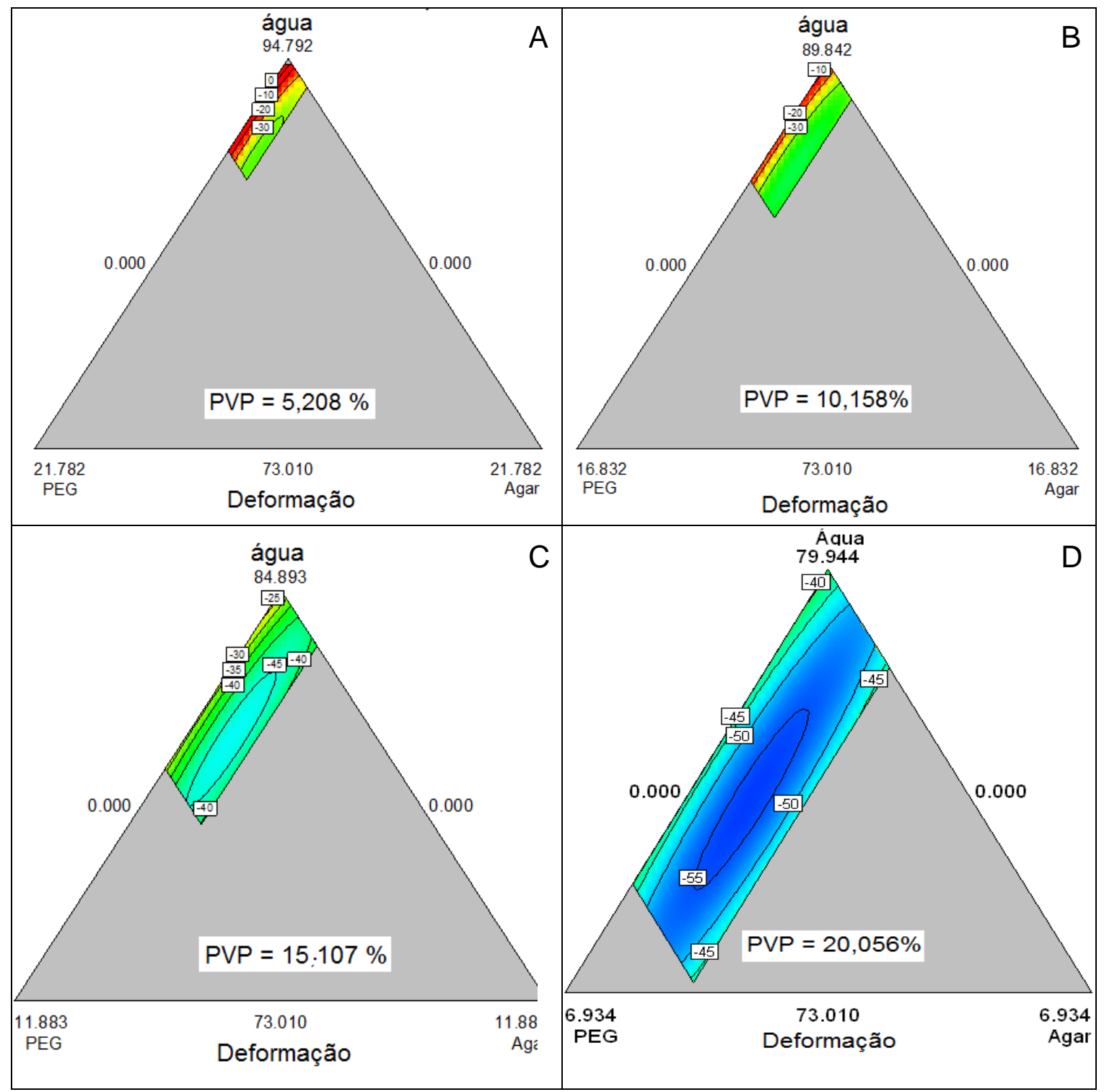

FIGURA 5.29 - Linhas de contorno da superfície de resposta que representam a variação do módulo elástico, para as misturas do sistema PVP/PEG/ágar com (A) $5 \%$ de PVP, (B) 10\% PVP, (C) 15\% PVP e (D) 20\% PVP. 


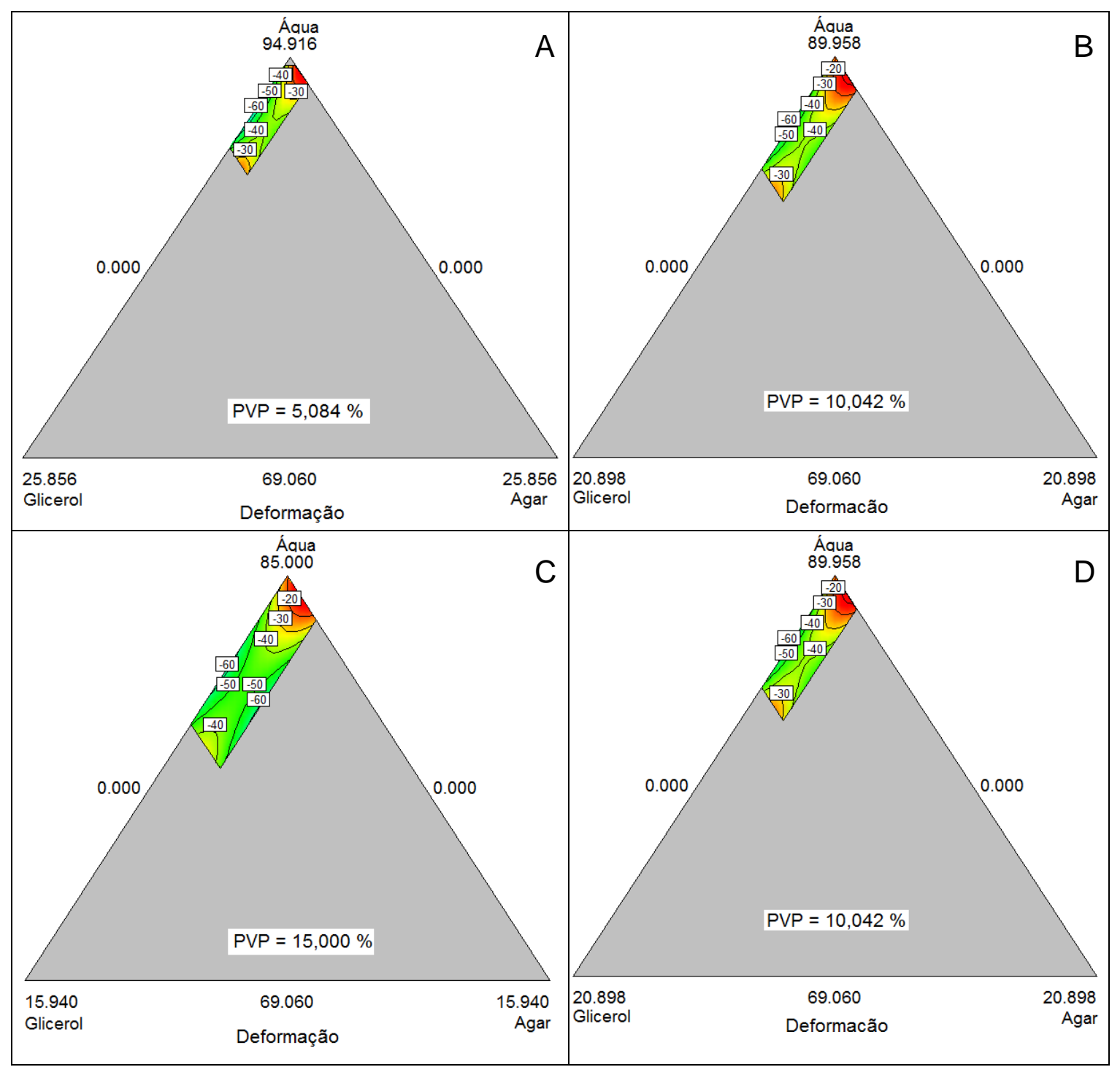

FIGURA 5.30 - Linhas de contorno da superfície de resposta que representam a variação do módulo elástico, para as misturas do sistema PVP/glicerol/ágar com (A) 5\% de PVP, (B) 10\% PVP, (C) 15\% PVP e (D) 20\% PVP.

\section{Sistema 3: PVA/KC/ágar}

Para obtenção de um modelo melhor ajustado aos resultados obtidos experimentalmente, foram eliminados os resultados provenientes dos hidrogéis de ordem padrão 18, 19 e 20. Os resultados obtidos, comparativamente aos previstos pela equação 5.21 estão apresentados na FIG. 5.30.

A regressão que melhor se ajustou aos dados foi o modelo cúbico especial, com $R^{2}$ aj. $=99,89 \%$. 


\section{Deformação na perfuração}

Ordem padrão - Hidrogel

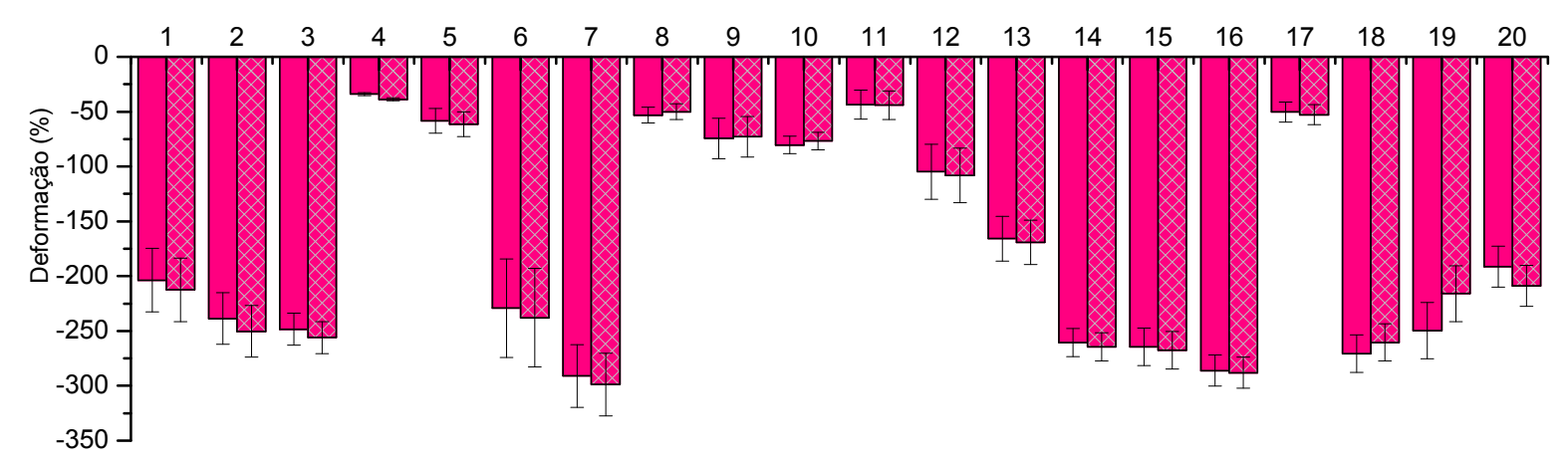

FIGURA 5.31 - Resultados de deformação, obtidos para o sistema 3.

$$
\begin{aligned}
\bar{\sigma}_{\mathrm{p}}(\mathrm{kPa})= & 323,76 \cdot x_{1}+68402,36 \cdot x_{2}+32788,44 \cdot x_{3}+5,49 \cdot x_{4}-969,33 \cdot x_{1} \cdot x_{2} \\
& -228,22 \cdot x_{1} \cdot x_{3}-4,22 \cdot x_{1} \cdot x_{4}-84716,21 \cdot x_{2} \cdot x_{3}-694,99 \cdot x_{2} \cdot x_{4} \\
& -332,93 \cdot x_{3} \cdot x_{4}+868,39 \cdot x_{1} \cdot x_{2} \cdot x_{3}+3,36 \cdot x_{1} \cdot x_{2} \cdot x_{4}-1,34 \cdot x_{1} \cdot x_{3} \cdot x_{4} \\
& +855,64 \cdot x_{2} \cdot x_{3} \cdot x_{4}
\end{aligned}
$$

Sistema 3, sendo:

$\bar{\sigma}_{\mathrm{p}}=$ Deformação na perfuração, concentrações \%, $\mathrm{x}_{1}=[\mathrm{PVA}], \mathrm{x}_{2}=[\mathrm{KC}], \mathrm{x}_{3}=$ [ágar $] \mathrm{e}$ $\mathrm{X}_{4}=$ [água $]$

A regressão sugere grande influência da $\mathrm{KC}$ e do ágar sozinhos, assim como importantes interações binárias e ternárias entre os componentes.

Testando o modelo com os resultados obtidos posteriormente, a partir da formulação otimizada do hidrogel, FIG. 5.35, o valor da deformação obtido foi $179,2 \pm 49,9 \%$ enquanto que o valor predito pelo modelo foi $66,6 \pm 2,1 \%$, indicando resultados incompatíveis. Porém, observando-se os resultados apresentados na FIG. 5.31, é possível notar que os resultados obtidos são compatíveis.

A representação gráfica do modelo cúbico especial, para 5\%, 10\% e 15\% de PVA pode ser observada FIG. 5.32 e sugere que são possíveis altos índices de deformação na perfuração, chegando até pouco mais de $300 \%$ para misturas isentas de ágar, em hidrogéis com 15\% de PVA. 


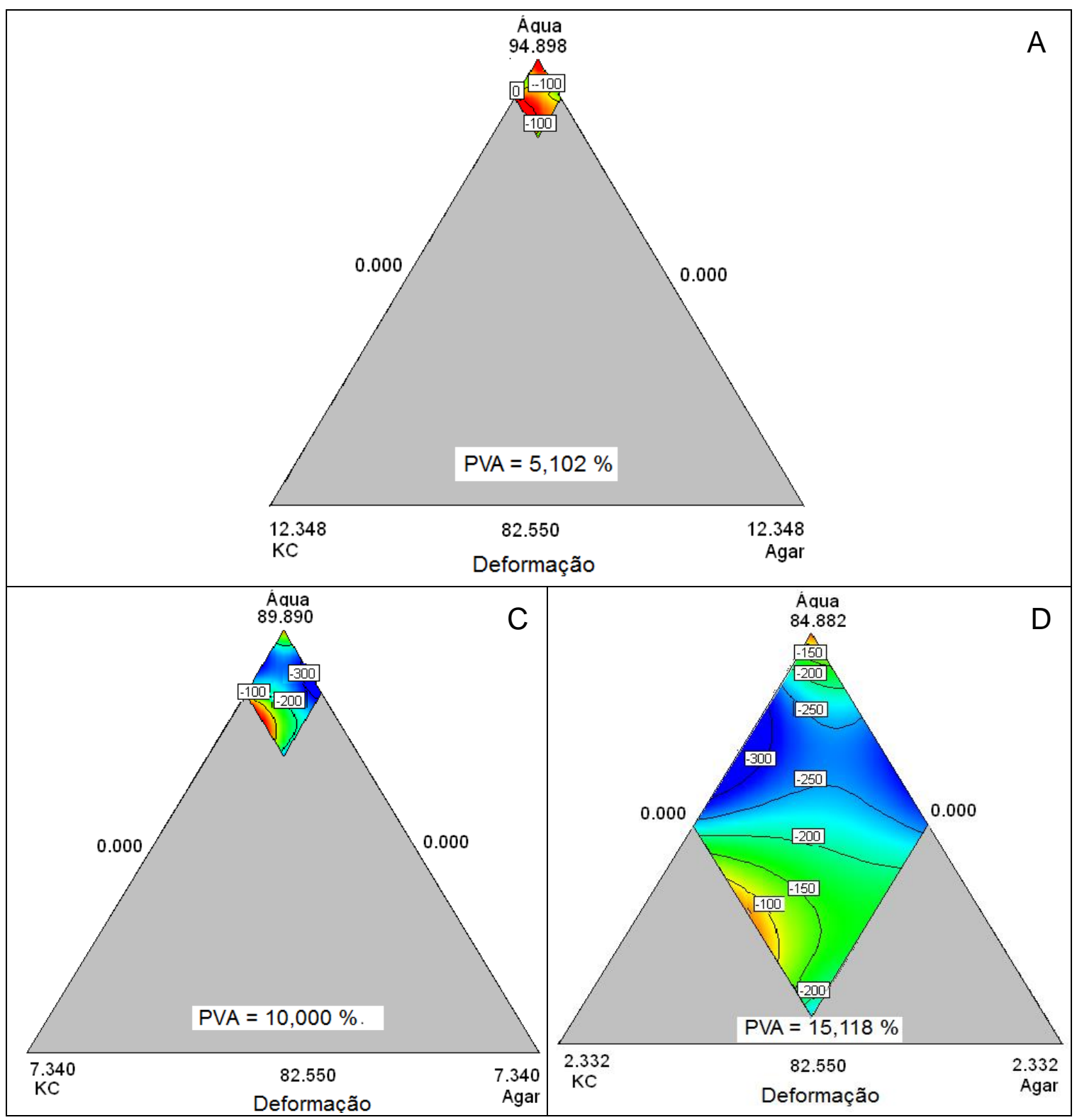

FIGURA 5.32 - Linhas de contorno da superfície de resposta para elongação na perfuração dos hidrogéis de PVA/KC/ágar com (A) 5\% PVA, (B) 10\% PVA e (C) $15 \%$ PVA.

\subsection{Otimização}

As composições obtidas para os hidrogéis otimizados estão apresentadas na TAB. 5.2, assim como a concentração da prata para cada uma das formulações com NPAg sintetizadas in situ. Não se observaram perdas significativas de água durante o processamento dos hidrogéis. 
TABELA 5.2 - Composição dos hidrogéis otimizados.

\begin{tabular}{cccc}
\hline Componentes & PVP/PEG/ágar & PVP/glicerol/ágar & PVA/KC/ágar \\
\hline PVP (\%) & 6,00 & 11,00 & - \\
PVA (\%) & - & - & 10,00 \\
PEG (\%) & 0,45 & - & - \\
Glicerol (\%) & - & 1,63 & - \\
Ágar (\%) & 1,50 & 1,50 & 0,63 \\
KC (\%) & - & - & 1,01 \\
Água (\%) & 92,05 & 85,87 & 88,36 \\
NPAg (ppm) & 40 & 40 & 60 \\
\hline
\end{tabular}

Os resultados preditos e obtidos para as propriedades dos hidrogéis otimizados, preparados com e sem prata, estão apresentados no item 5.5.

\subsection{Síntese das NPAg}

Na FIG. 5.33 estão apresentadas imagens das amostras dos hidrogéis otimizados, sintetizados com e sem prata.

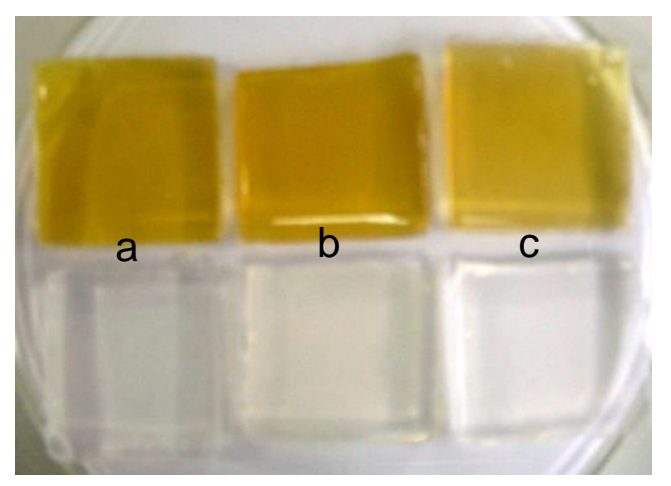

FIGURA 5.33 - Amostras dos hidrogéis otimizados preparados de acordo com a composição apresentada na TAB. 5.2, sendo: (a) PVP/PEG/ágar com e sem NPAg (b) PVP/glicerol/ágar com e sem NPAg e (c) PVA/KC/ágar com e sem NPAg.

A cor amarelada dos hidrogéis otimizados, sintetizados com prata via radiação ionizante, assim como as bandas plasmônicas obtidas nas análises de uv-visível, apresentadas na FIG. 5.34 indicam que houve a redução da Ag+ para $\mathrm{Ag}^{\circ}$, confirmando a formação, in situ, das NPAg .

Os espectros apresentam picos centrados entre $400 \mathrm{~nm}$ e $425 \mathrm{~nm}$, característicos de NPAg com formato esférico (Mock et al., 2002), porém com diferentes níveis de absorvância, para cada um dos grupos analisados. 
Entretanto, por se tratar de corpos de prova diferentes, com possível variação na espessura, não é possível afirmar que as diferenças observadas na absorvância estejam associadas às diferenças de concentração das NPAg formadas.

As amostras dos hidrogéis foram submetidas à espectroscopia de UVvisível ca. 3 h e 72 h depois de irradiadas. Após 72 h foram efetuadas 2 análises, uma delas com amostras mantidas em estufa a $50^{\circ} \mathrm{C}$, para acelerar o fim de possíveis reações incompletas, iniciadas no Gammacell.

Os espectros do hidrogel de PVP/PEG/ágar, FIG. 5.34 A que exibem pico da banda de absorção plasmônica em $\lambda \sim 413-425 \mathrm{~nm}$, sugerem que houve formação de partículas esféricas com ca. 8-10 nm, tendo em vista os resultados obtidos por Slistan-Grijalva et al. (2005), que sintetizaram NPAg em solução de etilenoglicol/nitrato de prata/PVP, enquanto que Jovanovic et al. (2012) que também sintetizaram NPAg por radiação obtiveram NPAg com pico da banda plasmônica em $\lambda=405 \mathrm{~nm}$ e 0 tamanho das partículas distribuídos entre 4 e 7 $\mathrm{nm}$.

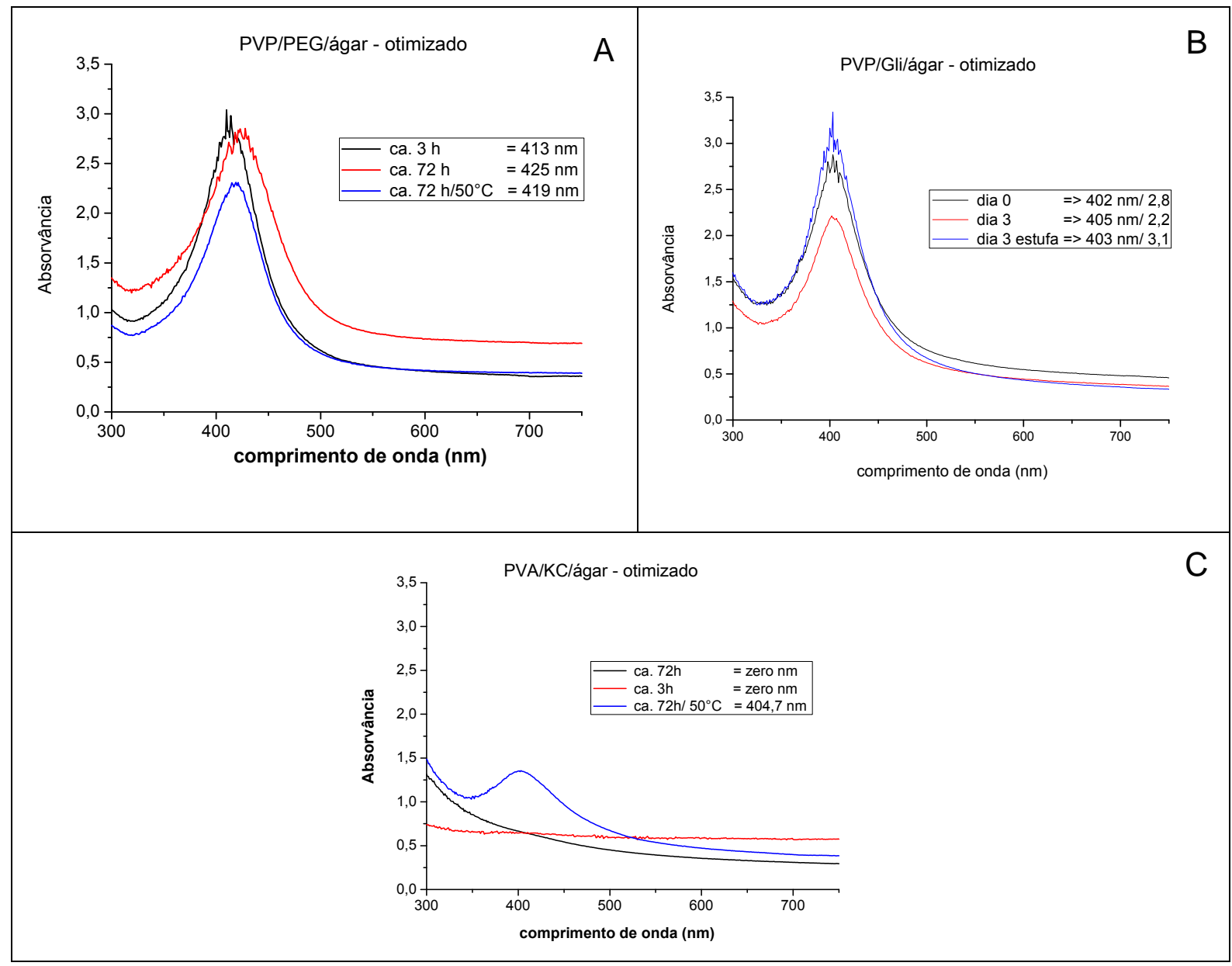

FIGURA 5.34 - Espectros de ressonância plasmônica obtidos para hidrogéis de (A) PVP/PEG/ágar, (B) PVP/glicerol/ágar e (C) PVA/KC/ágar. 
Observa-se também um pequeno deslocamento das bandas após $72 \mathrm{~h}$, sendo que a amostra submetida a um envelhecimento acelerado apresentou um estreitamento na sua largura enquanto que a outra apresentou um alargamento, ambas sugerindo que o sistema não se estabilizou imediatamente após a irradiação.

Para os hidrogéis de PVP/glicerol/ágar, observa-se que os picos das bandas plasmônicas não apresentaram deslocamento, permanecendo entre 402 $405 \mathrm{~nm}$, independentes do tempo em que as amostras foram analisadas após irradiadas e das condições em que foram submetidas, sugerindo que as reações de redução e estabilização da prata se completaram durante o processo de irradiação a 25 kGy ou após 72 h.

Foi observado pico no espectro da amostra do hidrogel de PVA/KC/ágar analisado somente após a mesma ter sido mantida em estufa por $72 \mathrm{~h}$ a $50^{\circ} \mathrm{C}$, indicando que a velocidade de reação, para formação das NPAg, é mais lenta que a velocidade de reação para formação da prata coloidal nos hidrogéis de PVP. O pico obtido apresenta absorção plasmônica em $405 \mathrm{~nm}$, característico de NPAg com formato esférico, conforme observado por Neto et al. (2008); entretanto, análises posteriores, efetuadas por MEV-FEG indicaram a presença de aglomerados, conforme mostrado na FIG. 5.44.

\subsection{Caracterização: Fórmulas otimizadas e com NPAg}

\subsubsection{Fração gel}

Os resultados de fração gel obtidos para os hidrogéis otimizados sintetizados com e sem NPAg estão apresentados na Fig. 5.35, comparativamente aos resultados preditos pelas regressões anteriormente obtidas. 


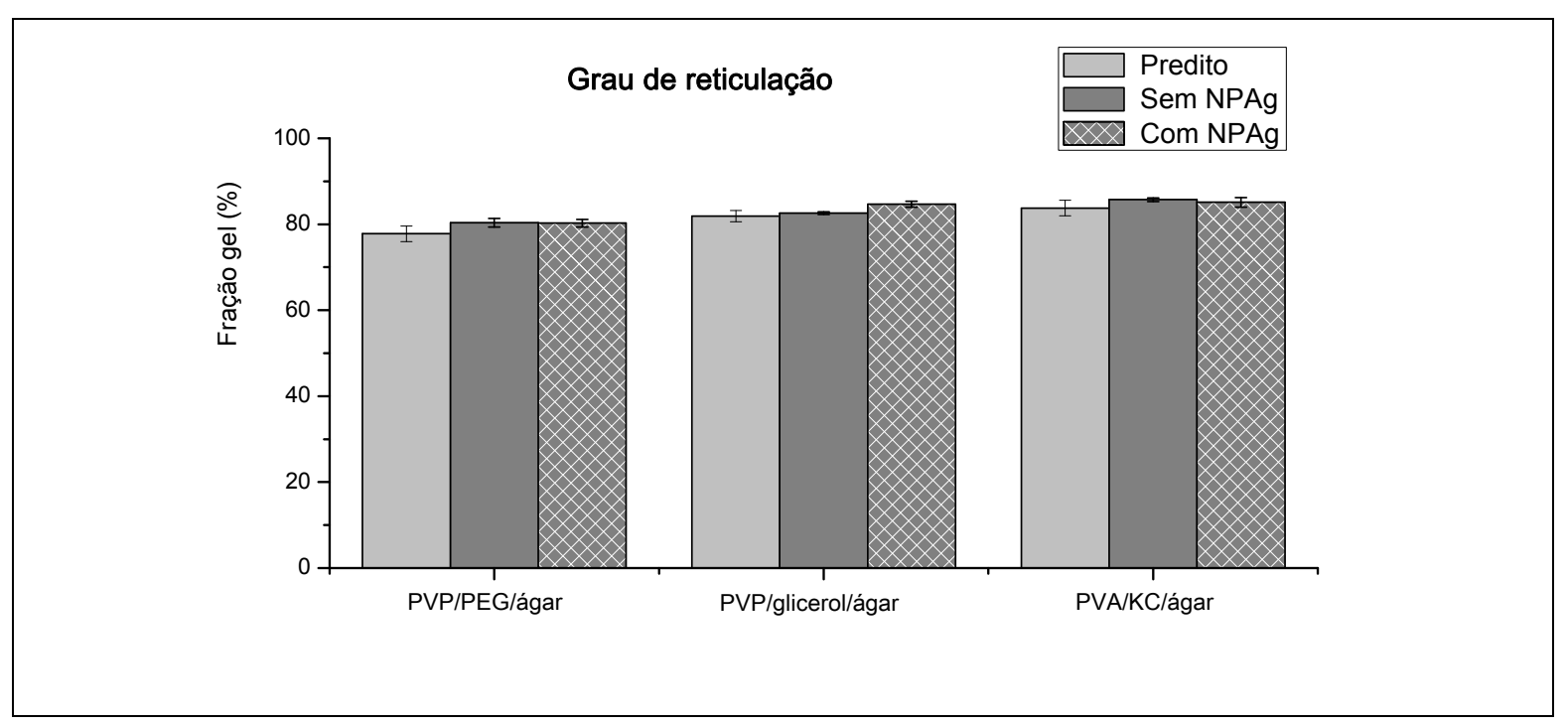

FIGURA 5.35 - Grau de reticulação dos três hidrogéis, com e sem NPAg.

Os resultados apresentados na FIG. 5.35 não mostram diferenças significantes entre os hidrogéis preparados com e sem prata.

Os resultados diferem do resultado obtido por Kumar et al. (2005), que avaliaram o efeito de íons $\mathrm{Ag}^{+}$na reticulação das cadeias de PVA, por meio da variação da viscosidade da solução com $5 \%$ de PVA $\left(\overline{M_{w}}=205.000 \mathrm{~g} \cdot \mathrm{mol}^{-1}\right)$, irradiada em doses que variaram entre ca. 0,5 a 3,5 kGy, na qual foi observada a redução da viscosidade com a formação de NPAg. Entretanto as comparações não puderam ser efetuadas em maiores doses devido à elevada viscosidade da solução sem prata.

\subsubsection{Intumescimento no equilíbrio}

Os resultados de intumescimento no equilíbrio obtidos para os três hidrogéis sintetizados, com e sem NPAg, comparativamente aos resultados preditos anteriormente, estão apresentados na FIG. 5.36. 


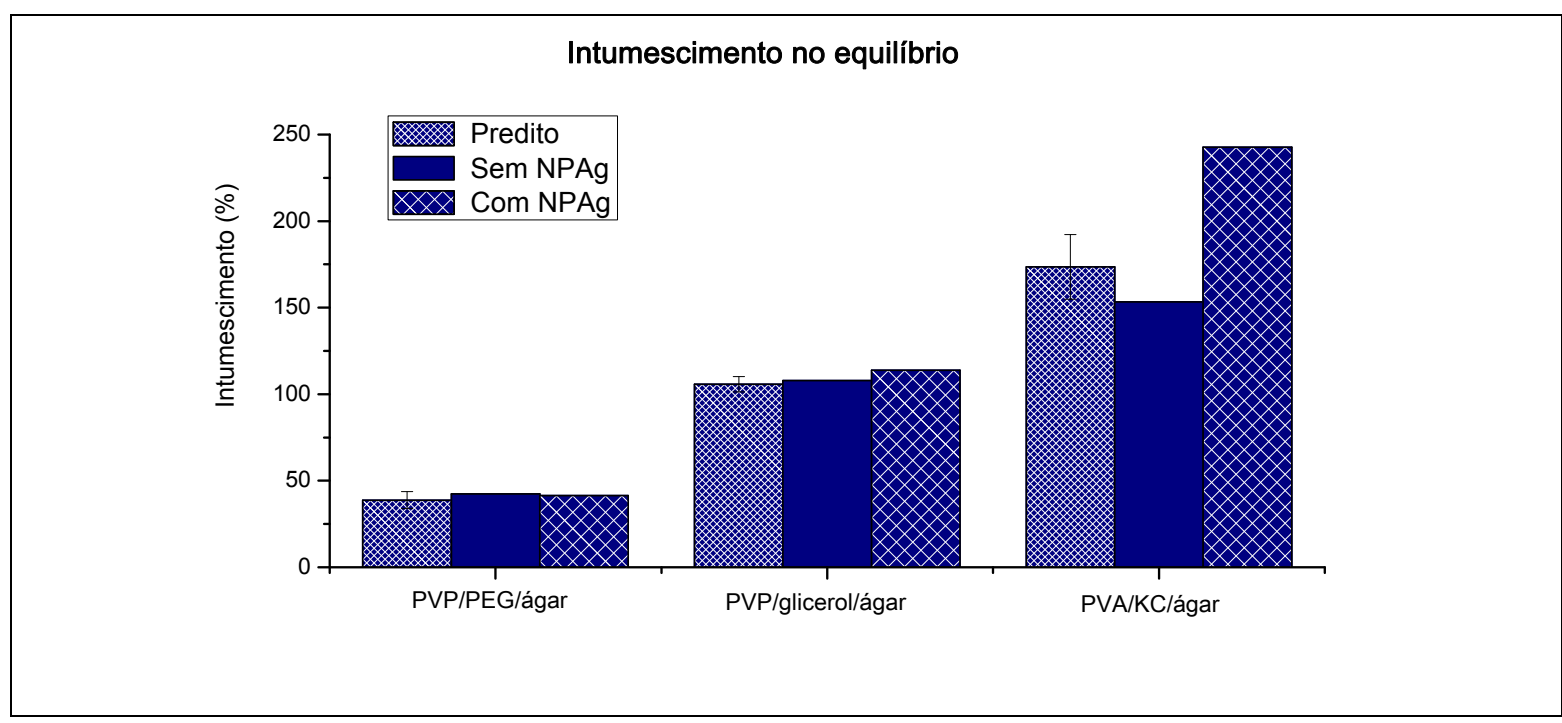

FIGURA 5.36 - Intumescimento no equilíbrio para dos três hidrogéis preparados, com e sem prata.

Os hidrogéis de PVP com prata atingiram o equilíbrio num patamar equivalente ao do hidrogel sem NPAg; diferentemente de Jovanovic et al. (2011), que observaram intumescimento no equilíbrio maior para o hidrogel de PVP com NPAg. Além disso, os resultados obtidos experimentalmente são similares aos preditos na otimização.

Diferentemente dos hidrogéis de PVP, os hidrogéis de PVA com e sem NPAg apresentaram equilíbrio no intumescimento em patamares bem distintos, sugerindo que a síntese das NPAg diminuiu a densidade de reticulação do polímero ou interferiu na enxertia, conforme suposto no estudo do intumescimento na seção 5.2.2. Também é possível observar que o resultado predito é diferente para o obtido experimentalmente, entretanto são compatíveis quando considerado o erro do modelo.

\subsubsection{Resistência à tração}

Na FIG. 5.37 está apresentada a média dos resultados de resistência à tração na ruptura, obtidos para cada um dos hidrogéis sintetizados com e sem NPAg, comparativamente aos resultados preditos pelas regressões obtidas. 


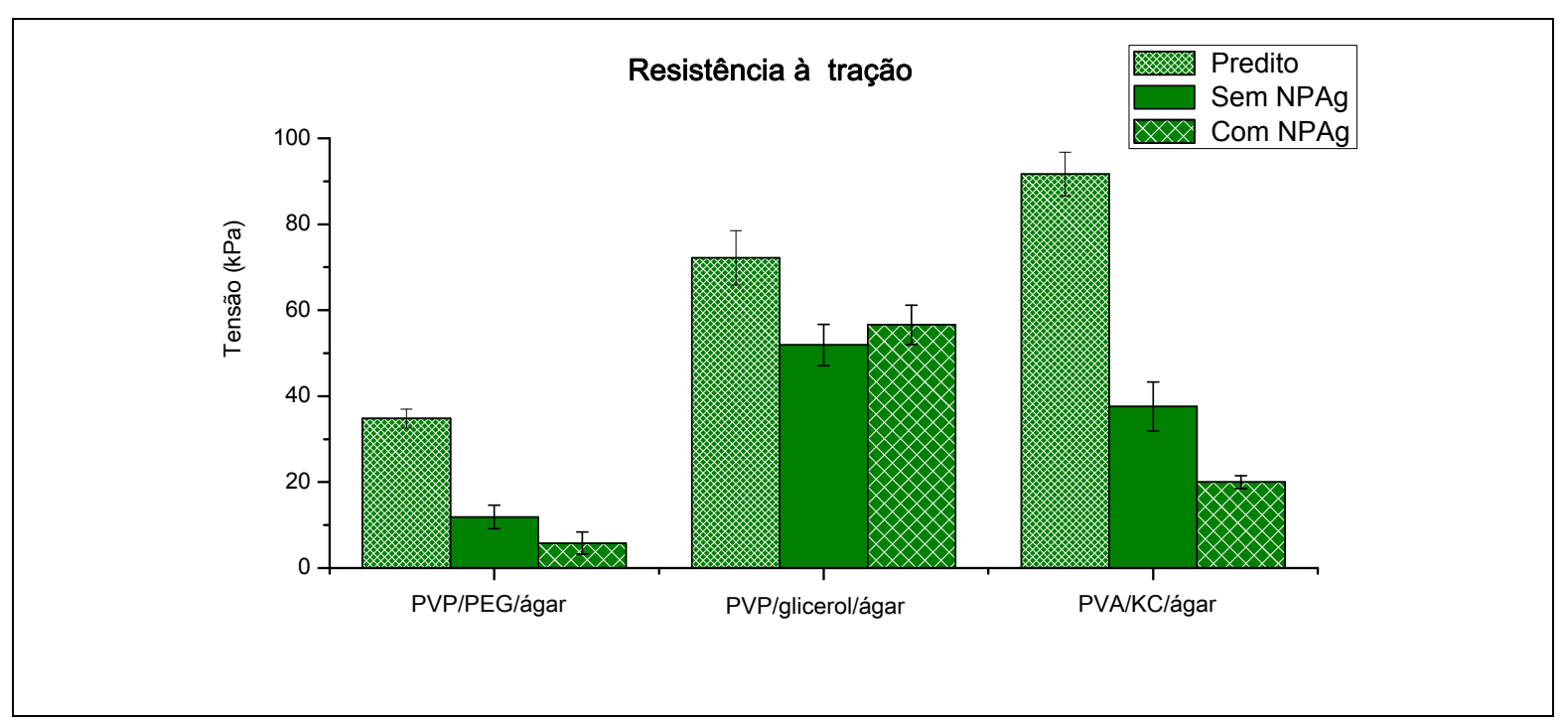

FIGURA 5.37 - Tensão na ruptura dos três hidrogéis otimizados, preparados com e sem prata, comparativamente aos resultados preditos na otimização.

Os resultados apresentados na FIG. 5.37 mostram diferenças significativas entre os valores preditos e obtidos, principalmente para os sistemas 1 e 3 . A resistência à tração obtida experimentalmente é inferior aos preditos para os três hidrogéis otimizados.

Em relação à resistência obtida para os hidrogéis sintetizados com e sem NPAg, a maior diferença foi a observada para o hidrogel de PVA/KC/ágar, corroborando com os resultados de intumescimento que sugerem a interferência das NPAg na formação da rede polimérica.

Para os hidrogéis de PVP/PEG/ágar, observa-se que a média da tensão de ruptura é $50 \%$ menor para o hidrogel com prata, enquanto que para o hidrogel de PVP/glicerol/ágar a síntese das NPAg aumentou o limite de resistência do hidrogel, neste caso corroborando com os resultados obtidos por Jovanovic' et al. (2011), que também sugeriram a influência das NPAg na estrutura da rede em hidrogéis de PVP, tornando-a ligeiramente mais firme e mais adequada para aplicações biomédicas, do ponto de vista da resistência mecânica.

\subsubsection{Deformação na tração}

A média dos resultados de deformação na tração até a ruptura para os hidrogéis com e sem prata, sintetizados com a composição otimizada, estão apresentadas na FIG. 5.38, comparativamente aos resultados preditos. 


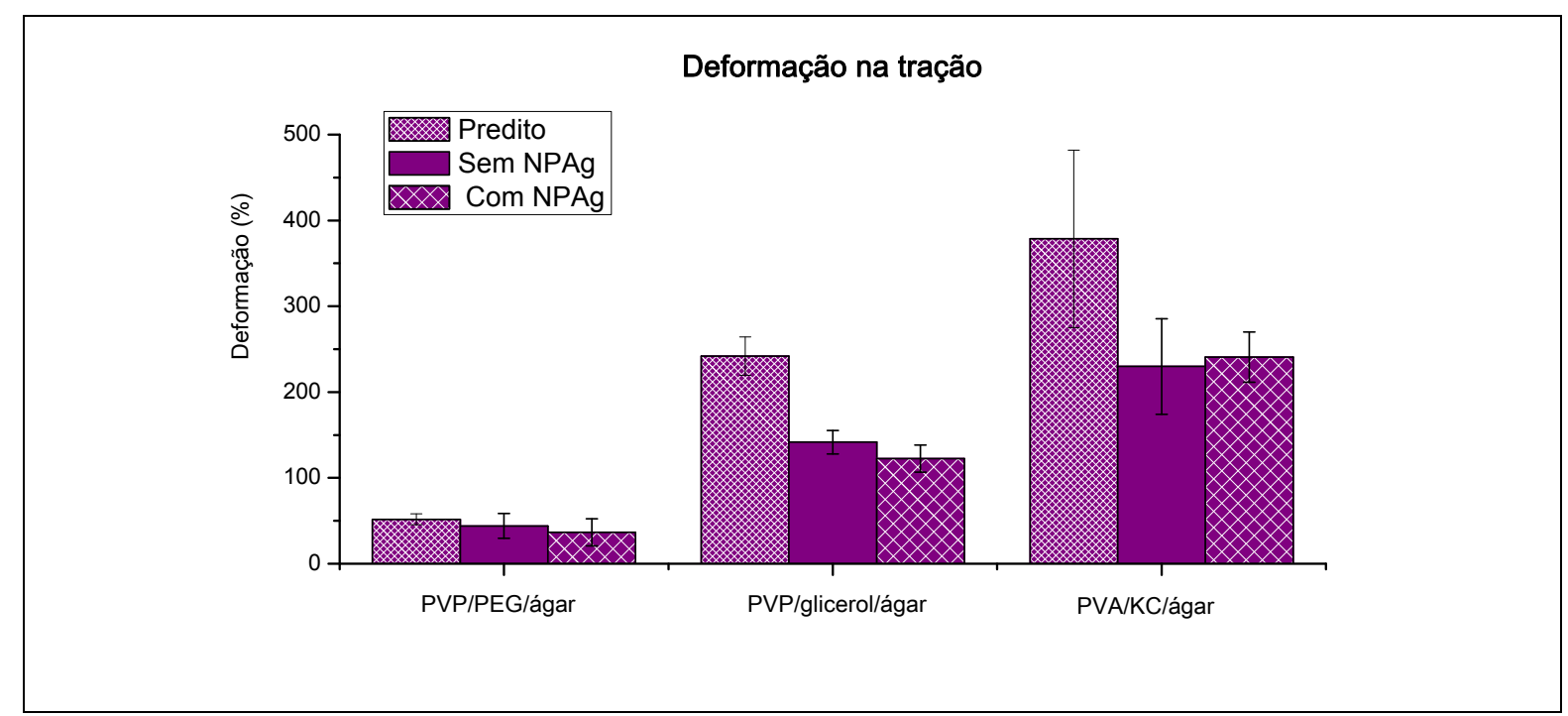

FIGURA 5.38 - Deformação na ruptura dos hidrogéis com e sem NPAg quando submetidos à tração.

As diferenças entre os resultados médios obtidos para os hidrogéis com e sem NPAg não são significativas, diferentemente dos resultados obtidos para os hidrogéis preditos e obtidos experimentalmente para os hidrogéis de $\mathrm{PVP} / \mathrm{glicerol/ágar} \mathrm{e} \mathrm{PVA/KC/ágar.}$

\subsubsection{Módulo elástico}

Os resultados de módulo elástico, para os três hidrogéis preparados com e sem prata estão apresentados na FIG. 5.39, comparativamente aos resultados preditos.

Para os três hidrogéis otimizados, os resultados obtidos experimentalmente foram inferiores aos resultados preditos pelas regressões determinadas. 


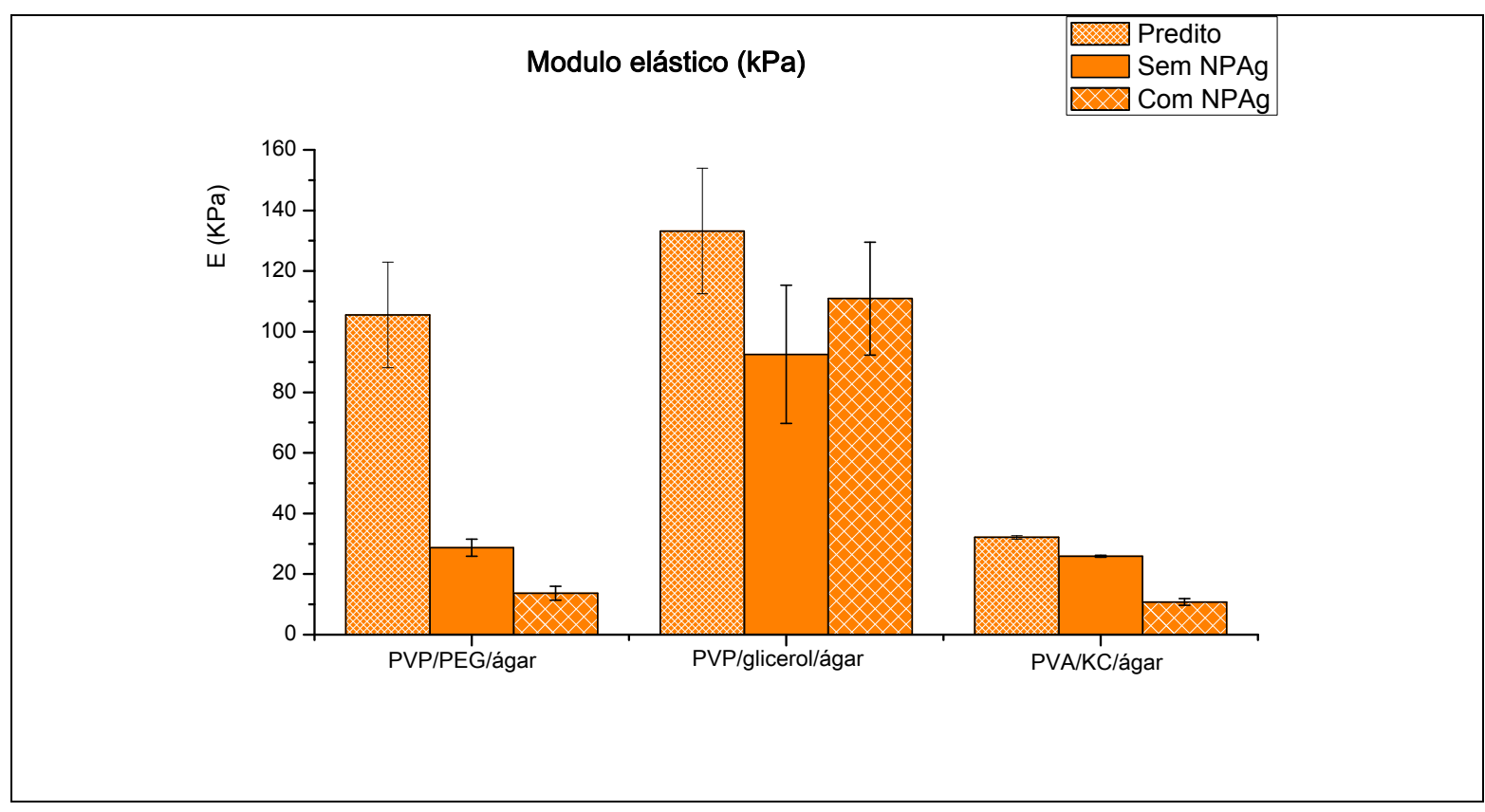

FIG. 5.39 - Resultados de módulo elástico para os três hidrogéis, preparados com e sem prata, comparativamente aos resultados preditos pela regressão.

Comparando os hidrogéis sintetizados com e sem NPAg, observa-se que os resultados obtidos para os hidrogéis de PVP/glicerol/ágar apresentam módulo elástico maior para os hidrogéis com NPAg, conforme também observado por Jovanovic' et al. (2011), que mediram o módulo elástico em hidrogéis de PVP e PVA/Ag por testes de compressão. No entanto, o contrário foi observado para os outros dois hidrogéis.

Os resultados gerais de propriedades mecâncias obtidos neste trabalho sugerem heterogeneidade nas redes formadas, como também observadas no hidrogéis estudados por Javanovic' et al. (2011). Entretanto não se podem desconsiderar os erros recorrentes dos resultados obtidos a partir das curvas de tensão $\mathrm{x}$ deformação de engenharia.

\subsubsection{Resistência à perfuração}

Os resultados de força puntiforme máxima obtida para perfuração dos hidrogéis sintetizados com composição otimizada, com e sem prata, estão apresentados na FIG. 5.40 e comparados aos resultados preditos pelas respectivas regressões obtidas anteriormente. 


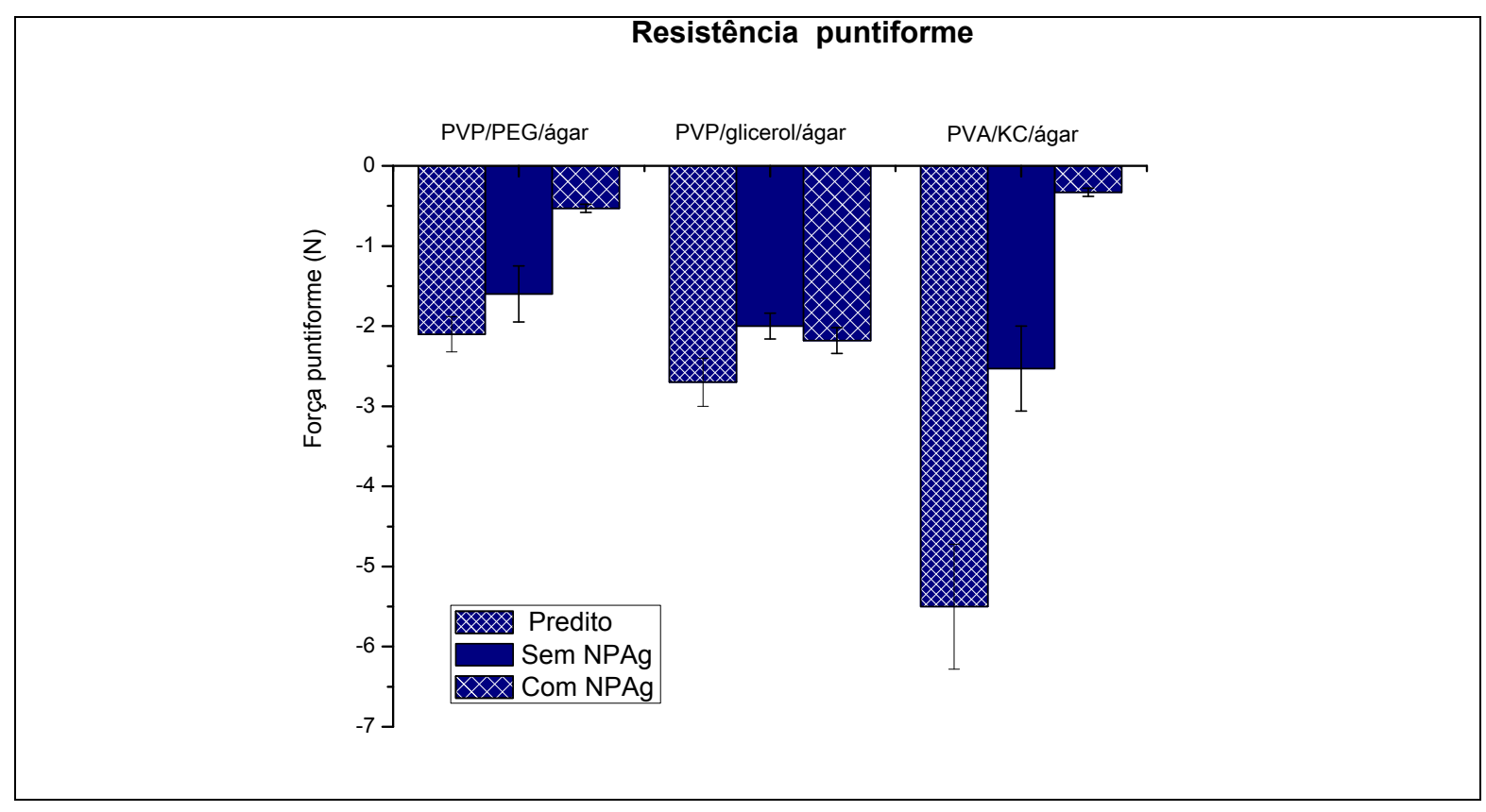

FIGURA 5.40 Comparação da resistência à perfuração, para os três hidrogéis otimizados, com e sem prata.

Os resultados preditos para os hidrogéis otimizados apresentam-se pouco superiores aos obtidos experimentalmente para os hidrogéis à base de PVP, entretanto para o hidrogel à base de PVA, o resultado predito foi mais de $50 \%$ superior aos determinados experimentalmente.

Comparando os resultados entre os hidrogéis sintetizado com e sem NPAg, observa-se similaridade ao obtido nos ensaios de resistência à tração, ou seja, apenas o hidrogel de PVP/glicerol/ágar apresentou resistência pouco menor para o hidrogel sem NPAg, enquanto que para os hidrogéis de PVP/PEG/ágar e PVA/KC/ágar aqueles sintetizados com NPAg apresentaram força inferior à dos hidrogéis sem NPAg.

\subsubsection{Deformação na perfuração}

Os resultados de deformação obtidos para os três hidrogéis otimizados, com e sem prata, estão apresentados na FIG. 5.41 e indicam que os valores preditos para os hidrogéis otimizados não diferem muito dos resultados obtidos para os hidrogéis de PVP, entretanto a diferença entre os hidrogéis de PVA com e sem NPAg é mais acentuada do que observado na deformação quando submetido à tração. 


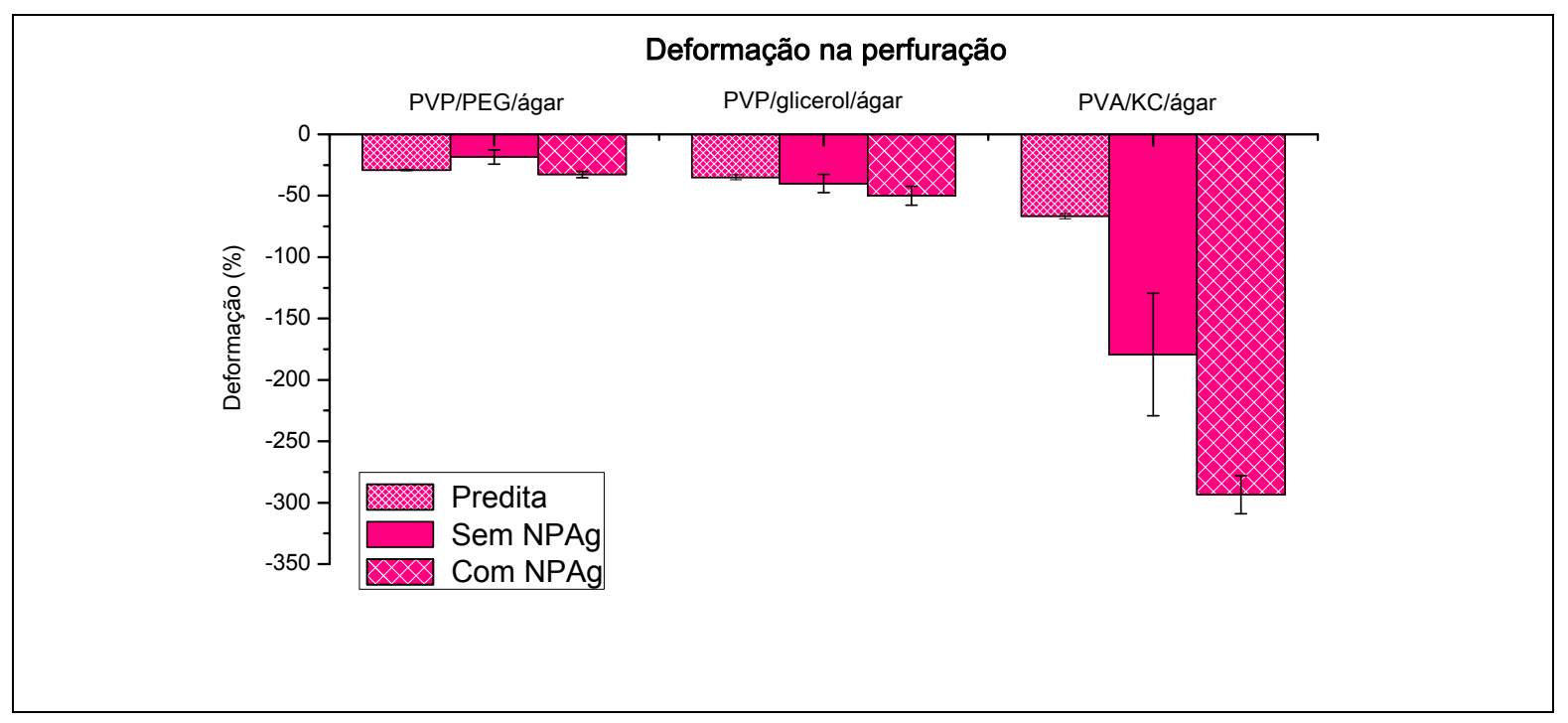

FIGURA 5.41 - Resultados comparativos de deformação, para os hidrogéis com e sem prata, quando submetidos à perfuração.

\subsubsection{Propriedades morfológicas}

As estruturas internas dos hidrogéis otimizados, com e sem prata, foram observadas por SEM e comparadas entre si, após liofilização, para que seus poros não colapsassem e suas estruturas se mantivessem fidedignas. As imagens das superfícies de fratura estão apresentadas na FIG. 5.42.

As FIG. 5.36 A e B, que apresentam a microestrutura dos hidrogéis de PVP/PEG/ágar sem e com prata, respectivamente, mostram estruturas altamente porosas, porém o hidrogel sem prata apresenta formas bem definidas e com certa homogeneidade na distribuição, enquanto que o tamanho dos poros do hidrogel com prata é mais heterogêneo e estes estão distribuídos de uma forma mais irregular.

Os hidrogéis de PVP/glicerol/ágar apresentaram estrutura pouco mais densa que os hidrogéis de PVP/PEG/ágar, justificando sua maior resistência média à tensão e deformação; no entanto, sua maior capacidade de intumescimento, como observado nas FIG. 5.36, deve-se à maior concentração de glicerol, que é mais hidrofílico que o PEG. Observa-se que o hidrogel com prata apresenta-se pouco mais poroso que o hidrogel sem prata, porém ambos possuem estrutura com forma muito irregular. 


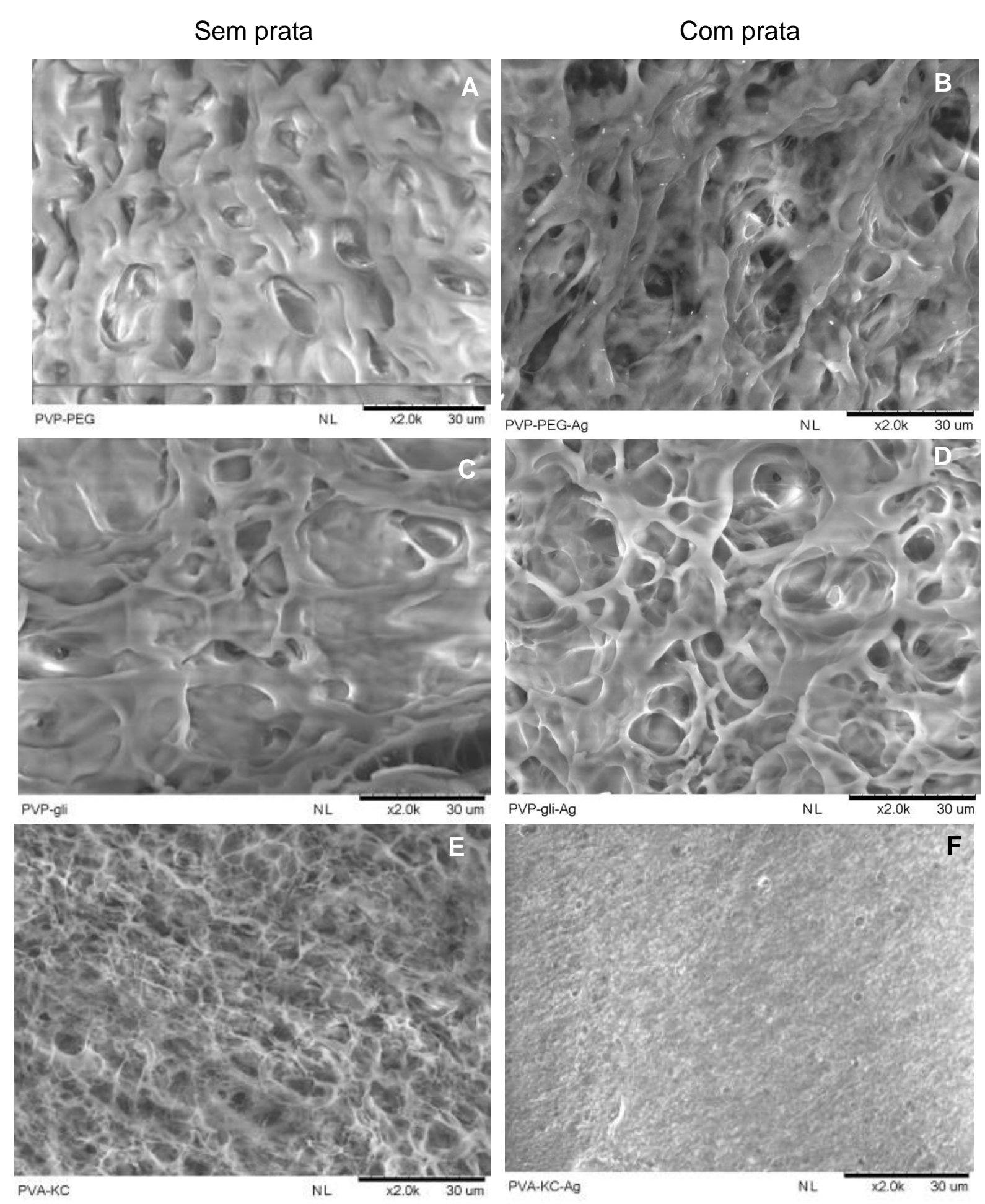

FIGURA 5.42 - Micrografia de fratura dos hidrogéis liofilizados. (A e B) amostras de PVP/PEG/ágar, sem e com NPAg respectivamente, (C e D) amostras de $\mathrm{PVP} /$ glicerol/ágar, sem e com NPAg e (E e F) amostras de PVA/KC/ágar, sem e com NPAg, respectivamente.

Observando a micrografia do hidrogel de PVA/KC/ágar sem prata, apresentada na FIG. 5.42 E, é possível observar poros muito pequenos, totalmente irregulares e com paredes mais finas e delicadas, lembrando um 
emaranhado de teia de aranha, bem diferente do observado nos hidrogéis de PVP com prata onde se observa uma estrutura mais densa, com pequenos poros de formato regular e homogeneamente distribuídos. Enquanto que o hidrogel de $\mathrm{PVA} / \mathrm{KC} /$ ágar com prata apresenta estrutura mais densa que o hidrogel sem prata, com pequenos poros de formato regulares, também homogeneamente distribuídos.

\subsubsection{Distribuição das NPAg nos hidrogéis otimizados}

Tendo em vista a dimensão das nanoparticulas, normalmente as análises microscópicas são efetuadas por Microscopia Eletrônica de Transmissão (MET), entretanto os hidrogéis sintetizados são blendas, que diferentemente dos estudos encontrados na literatura degradam quando submentidos a feixe de elétrons com maior energia como é o caso da MET; por isso foram efetuadas análises em SEM, acoplado ao sistema EDS (Energy Dispersive System) e SEM-FEG (microscópio eletrônico de varredura com canhão com emissão por efeito de campo) na expectativa de obter alguma informação adicional, em relação às nanoparticulas sintetizadas.

Para analisar a distribuição da prata na superfície e no interior dos hidrogéis as amostras foram desidratadas em estufa, tendo em vista que se observou, visualmente, que grande parte da prata migrou para a superfície durante a liofilização.

A análise da distribuição da prata nos hidrogéis por SEM-EDS fornece o mapa químico de uma área exposta ao feixe de elétrons, e desta forma, é possível representar a distribuição quantitativa da amostra, por emissão de raios $X$ (Duarte et al., 2003).

As observações efetuadas na fratura e superfície das amostras de PVP/PEG/ágar, PVP/glicerol/ágar e PVA/KC/ágar, mostram uma distribuição homogênea de NPAg nos três hidrogéis preparados, sem aglomerados significantes, conforme apresentado na FIG. 5.43. 


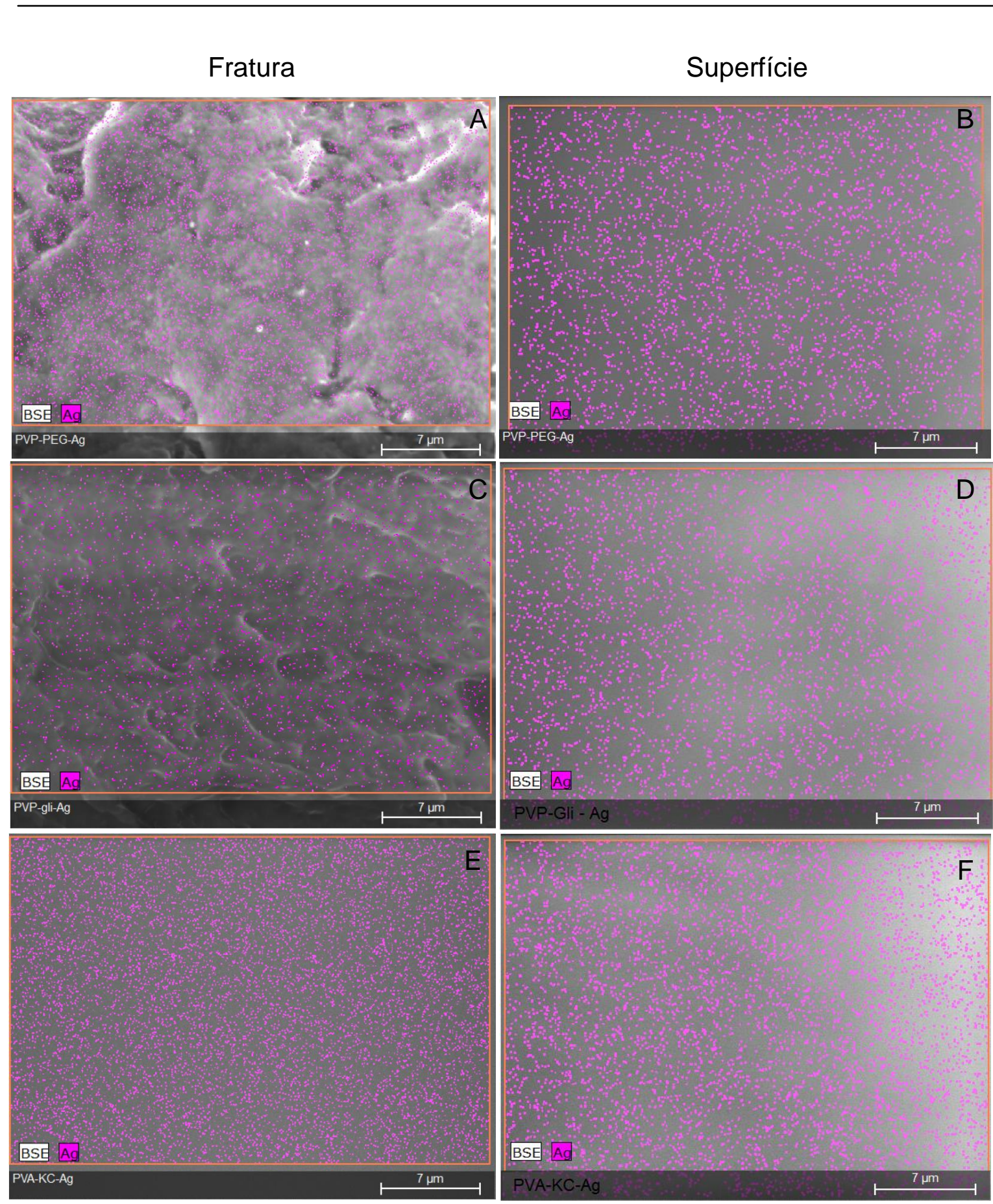

FIGURA 5.43 - Micrografias de SEM com EDS acoplado, mostrando a distribuição de prata na fratura e superfície de amostras de hidrogéis desidratados em estufa. (A-B) hidrogel de PVP/PEG/ágar, (C-D) hidrogel de $\mathrm{PVP} / g$ licerol/ágar e (E-F) hidrogel de PVA/KC/ágar.

Nas análises de morfologia efetuada por SEM-FEG, não foi possível observar NPAg nos hidrogéis nem sua distribuição, como observado nos mapas químicos apresentados na FIG. 5.43. Entretanto, em duas amostras de hidrogel de PVA/KC/ágar investigadas foram encontrados aglomerados de prata coloidal, da ordem de até $10 \mu \mathrm{m}$, conforme apresentado na FIG. 5.44. 
Tendo em vista que as imagens de SEM-FEG apresentam alta resolução, é possível visualizar no fundo regiões mais densas e outras porosas, irregular e com grânulos, possivelmente resultado de uma solubilização incompleta dos componentes.
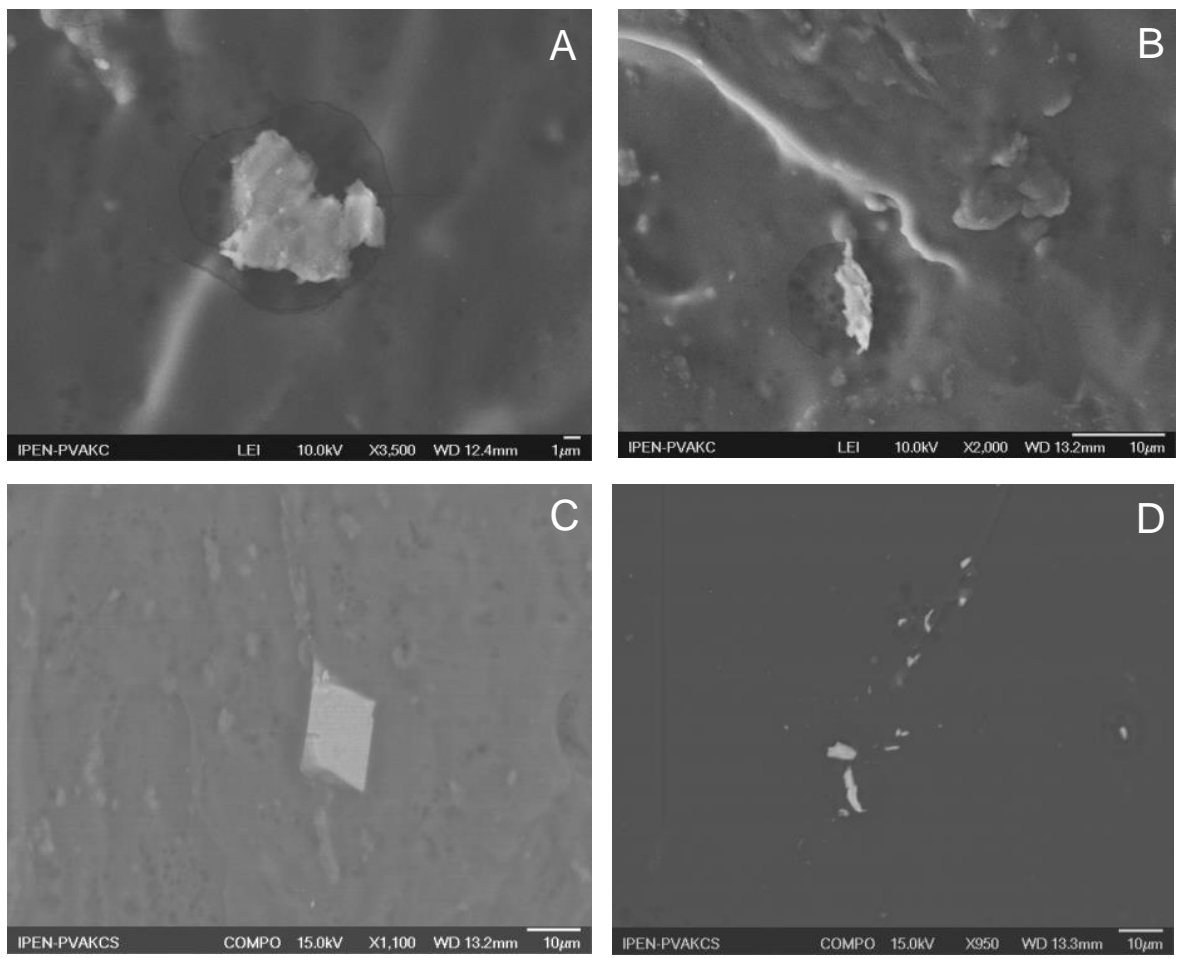

FIGURA 5.44 - Micrografias de aglomerados de prata coloidal em superfície de hidrogel de PVA/KC/ágar observados por MEV-FEG.

\subsubsection{0 - Atividade antimicrobiana das NPAg}

Os testes de atividade antimicrobiana foram realizados pela Bel. Priscila Martins dos Santos, sob orientação do Prof. Dr. Nilton Erbet Lincopan Huenuman, do Instituto de Ciências Biomédicas - ICB/USP, visando avaliar as propriedades antimicrobianas dos hidrogéis com NPAg, sintetizadas in situ.

Os testes foram realizados com bactéria gram-negativa - $S$. aureus e grampositiva - Pseudomonas aeruginosa.

\section{Teste de disco-difusão em ágar}

O teste de disco-difusão, também chamado método Kirby-Bauer, cujo princípio básico é a difusão do antimicrobiano na superfície do ágar, é um dos métodos de suscetibilidade mais simples, confiável e mais utilizado pelos laboratórios de microbiologia, fornecendo resultados qualitativos (ANVISA, 2008). 
Entretanto, a interpretação dos resultados dos testes de sensibilidade a antimicrobianos por disco-difusão, não se mostraram eficazes, conforme pode ser observado na FIG. 5.45 A e B, uma vez que não houve formação de halo para nenhum dos hidrogéis testados, tanto contra $S$. aureus como $P$. aeruginosa, como observado na FIG. 5.45 C que apresenta o controle positivo (ciprofloxacina) para comparação. A pequena falha observada principalmente ao redor da amostra de hidrogels de PVA, para $S$. aureus não pode ser interpretada como sendo halo, tendo em vista a não uniformidade da mesma, ao contrário do que pode ser observado no controle positivo, apresentado na FIG. 5.45 C.

$P$. aeruginosa

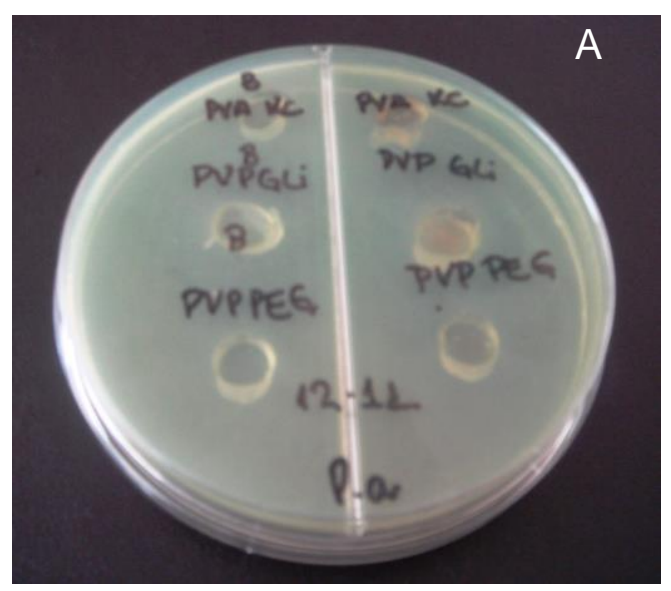

S. aureus

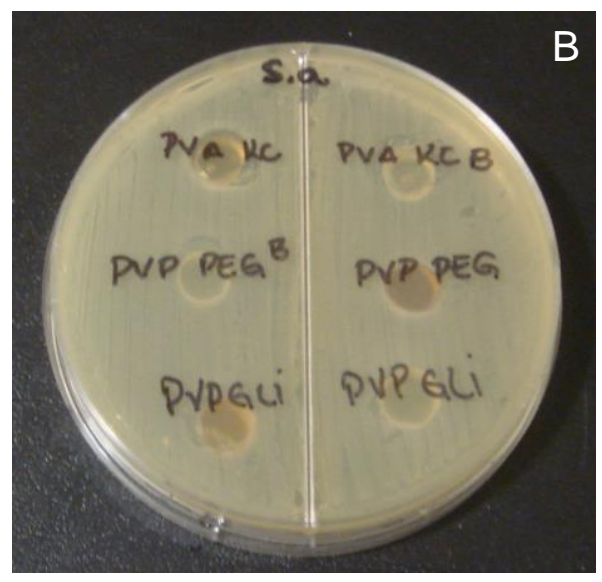

$P$. aeruginosa $S$ aureus

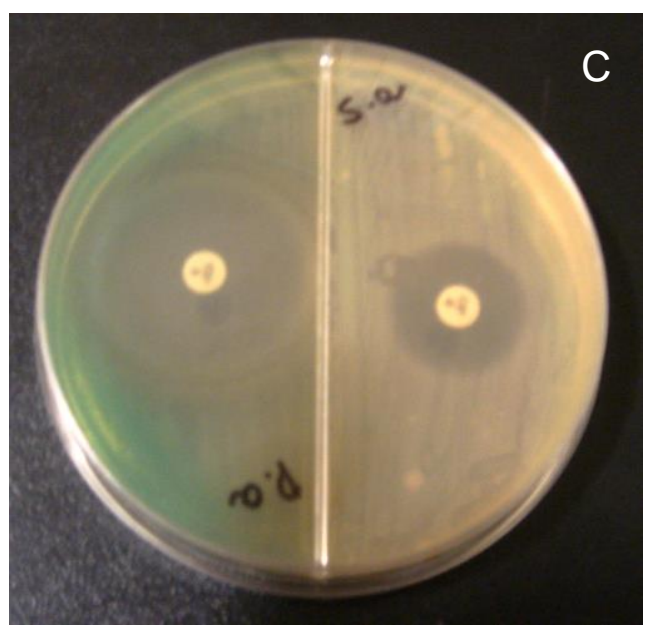

FIGURA 5.45 - Teste de sensibilidade antimicrobiana dos hidrogéis preparados com prata, usando como controle positivo os próprios hidrogéis, porém sem prata. (A) Teste contra $P$. aeruginosa, (B) $S$. aureus. (C) controle positivo (ciprofloxacina) para $P$. aeruginosa e $S$. aureus. 


\section{Método de diluição em caldo}

$\mathrm{Na}$ FIG. 5.46 estão apresentadas as placas resultantes dos testes de atividade antimicrobiana contra $P$. aeruginosa e $S$. aureus para os hidrogéis de PVP/PEG/ágar/NPAg, PVP/glicerol/ágar/NPAg e PVA/KC/ágar/NPAg, sendo o controle negativo o hidrogel com mesma composição, porém sem NPAg.

$\mathrm{Na}$ FIG. 5.46 A a placa indicada como controle negativo apresenta coloração esverdeada, típica de $\mathrm{P}$. aeruginosa, enquanto que a outra não apresenta coloração, indicando que após $24 \mathrm{~h}$ de incubação o resultado das amostras avaliadas é negativo para o hidrogel com NPAg e portanto o hidrogel de PVP/PEG/ágar com NPAg apresentou atividade antimicrobiana contra $P$. aeruginosa.

\section{P. aeruginosa}

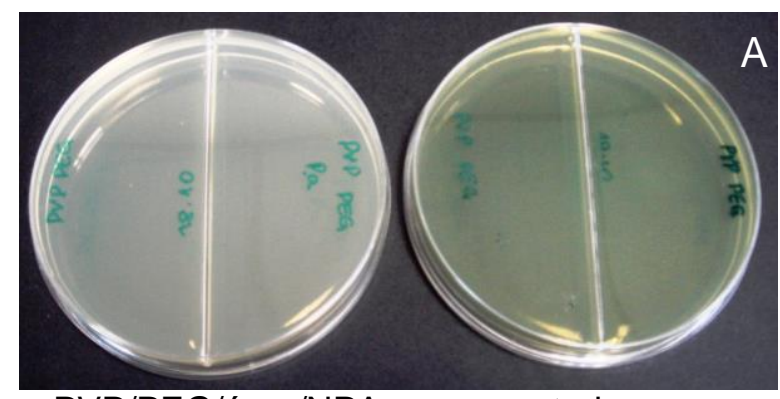

PVP/PEG/ágar/NPAg controle -
S. aureus

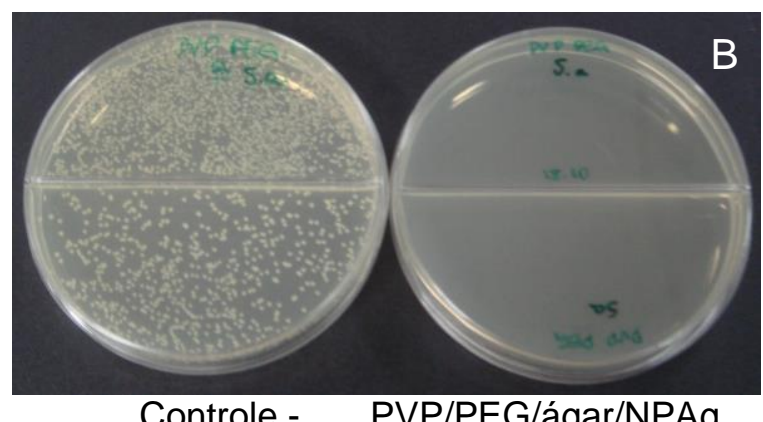

Controle -

FIG. 5.46 - Resultados obtidos no teste de avaliação da atividade microbiana para o hidrogel de PVP/PEG/ágar contra (A) $P$. aeruginosa e (B) S. aureus.

Na FIG. 5.46 B observa-se a formação de colônias de $S$. aureus no controle negativo, enquanto que na placa ao lado não se observa nenhuma formação de colônia, indicando que o hidrogel de PVP/PEG/ágar com NPAg também apresentou atividade antimicrobiana para $S$. aureus.

Os resultados obtidos para os hidrogéis de PVP/glicerol/ágar indicam que as amostras testadas apresentaram atividade antimicrobiana para $P$. aeruginosa $e$ S. aureus, confome apresentada na FIG.5.47 A e B. 
$P$. aeruginosa

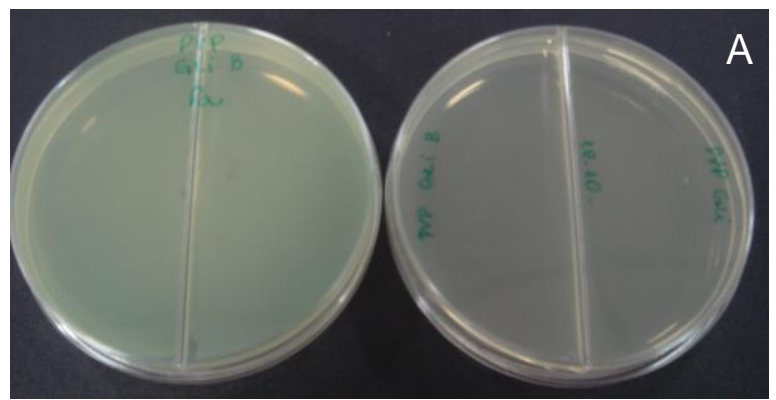

Controle -

PVP/glicerol/ágar/NPAg
S. aureus

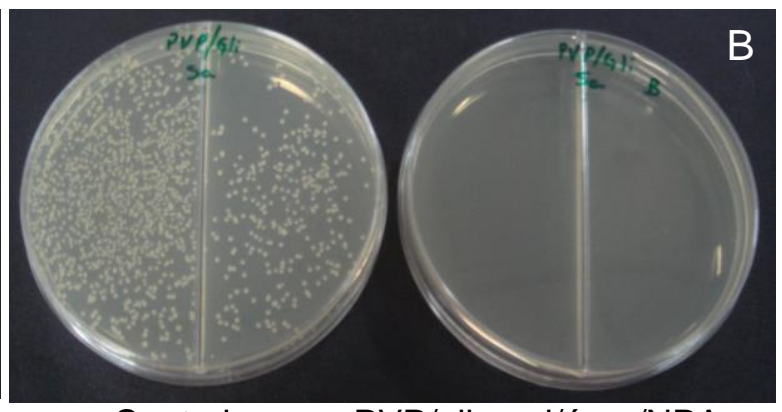

Controle -

PVP/glicerol/ágar/NPAg

FIGURA 5.47 - Resultados obtidos no teste de avaliação da atividade microbiana para o hidrogel de PVP/glicerol/ágar contra (A) $P$. aeruginosa e (B) $S$. aureus.

Os resultados obtidos para os hidrogéis de PVA/KC/ágar, apresentados na FIG. $5.48 \mathrm{~A}$, indicam que 0 hidrogel com NPAg apresentou atividade antimicrobiana contra $P$. aeruginosa. No entanto, o resultado para atividade contra S. aureus é bem diferente do obtido para os hidrogéis de PVP testados e apresentou resposta atípica.

\section{$P$. aeruginosa}

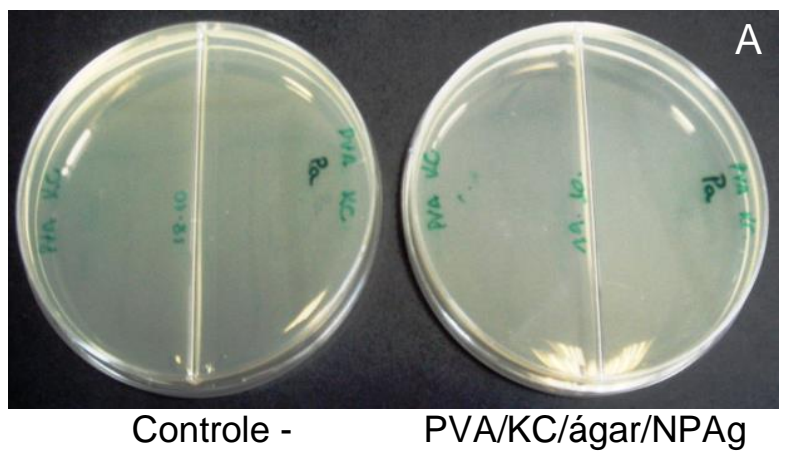

S. aureus

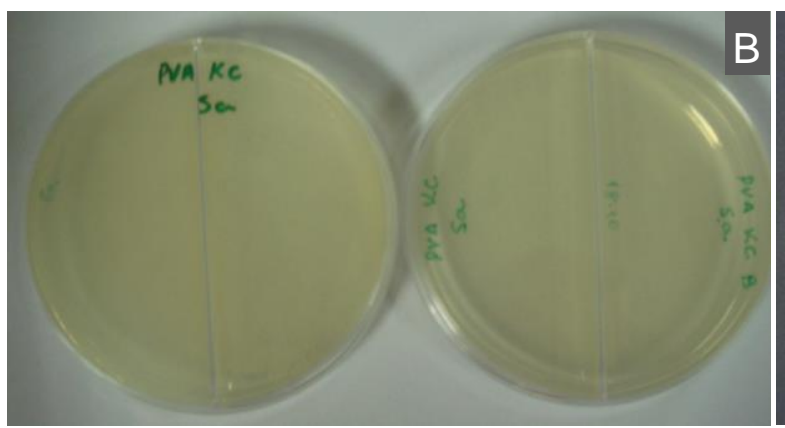

Controle - 24 h PVA/KC/ágar/NPAg

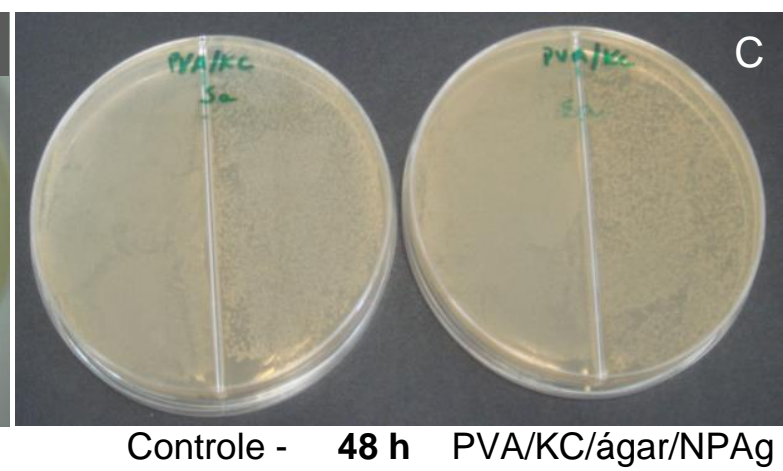

Controle - 48 h $\quad$ PVA/KC/ágar/NPAg

FIG. 5.48 - Resultados obtidos no teste de avaliação da atividade microbiana para o hidrogel de PVA/KC/ágar contra $S$. aureus para tempo de incubação de (A e B) $24 \mathrm{~h}$ e (C) $48 \mathrm{~h}$. 
Como pode ser visto na FIG. 5.48 B, não houve crescimento de colônia de $S$. Aureus com $24 \mathrm{~h}$ de incubação para o hidrogel com NPAg nem para o hidrogel sem NPAg, usado como controle negativo. Entretanto, para as placas mantidas em estufa por $48 \mathrm{~h}$ foi observado crescimento de colônias nas duas placas, indicando que os hidrogéis de PVA/KC/ágar apresenta atividade bacteriostática para $S$. aureus. Os testes foram repetidos e os resultados confirmados.

Tendo em vista os resultados observados nos testes, utilizando as metodologias da difusão e de diluição em caldo, acredita-se que:

- A não formação de halo no primeiro teste sugere que os hidrogéis de PVP/PEG/ágar e PVP/glicerol/ágar não liberaram as NPAg para que estas pudessem se difundir e matar as bactérias presentes no ágar, como observado no controle, cujo ativo é um antibiótico que é liberado para o meio.

- A não formação de colônias de $S$. aureus com 24 h, no teste que utilizou a diluição em caldo, sugere que os dois hidrogéis (com e sem prata) apresentam atividade antimicrobiana para essa bactéria, entretanto essa atividade é baixa e nem mesmo o hidrogel com prata consegue matar todas as bactérias, permitindo assim a proliferação das mesmas.

Por outro lado, os espectros de uv-visível obtidos para os três hidrogéis com NPAg estudados, FIG. 5.34, sugerem a formação de menor quantidade de NPAg para o hidrogel de PVA/KC/ágar que para os hidrogéis à base de PVP.

\subsubsection{Citotoxicidade in vitro}

A avaliação biológica de dispositivos médicos é uma forma de verificar a potencial toxicidade proveniente de resíduos tóxicos formados durante o processo de produção. Para ser utilizado como biomaterial o mesmo precisa ser biocompatível, ou seja, deverá interagir com o meio fisiológico sem passar por alterações nem provocar dano aos tecidos (ISO 10993-1, 1992).

A ISO 10993-1 sugere que o teste in vitro de citotoxicidade seja o primeiro a avaliar a biocompatibilidade de um material e neste caso os efeitos tóxicos são avaliados em células.

Os testes de citotoxicidade foram realizados pela Dra. Priscilia Aguilar Ramirez, sob a coordenação do Prof. Nilton Lincopan, ambos do Instituto de Ciências Biomédicas - ICB/USP, e os resultados estão apresentados na FIG. 5.49 . 
Os resultados apresentados indicam que os hidrogéis de PVP/glicerol/ágar foram os que mostraram menor toxicidade para os fibroblastos, sendo o hidrogel com NPAg ainda menos tóxico que o hidrogel sem NPAg. Por outro lado, o hidrogel de PVP/PEG/ágar foi o que apresentou maior índice de citotoxicidade para todas as diluições do extrato, com exceção do extrato puro do mesmo hidrogel com NPAg, que superou todos os demais índices.

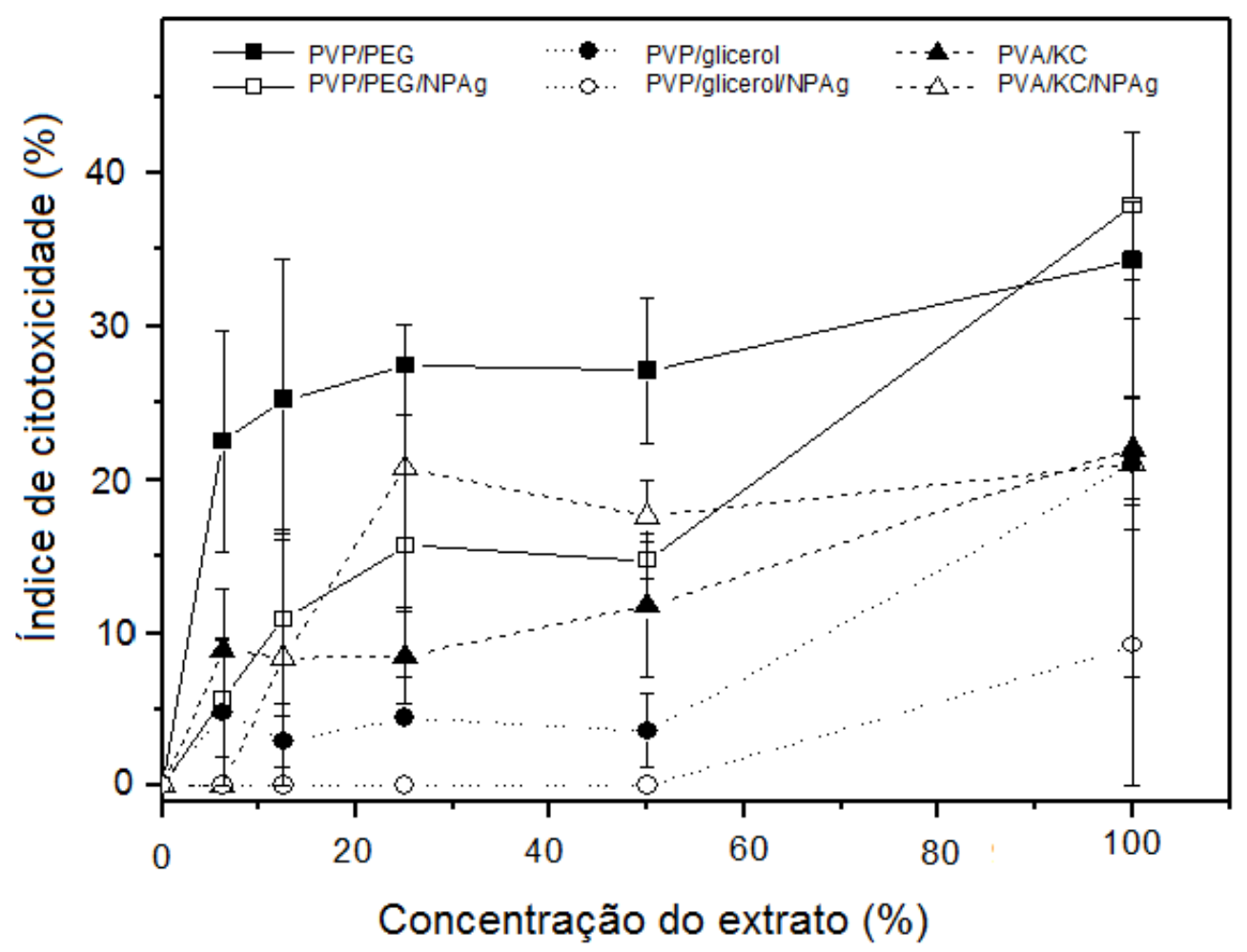

FIGURA 5.49 - Avaliação da citotoxicidade obtida pelo método de captura do vermelho neutro para soluções de extrato dos hidrogéis de PVP/PEG/ágar, PVP/glicerol/ágar e PVA/KC/ágar, todos com e sem NPAg.

Entre os hidrogéis testados, os hidrogéis de PVP/PEG/ágar foram os que apresentaram maior citotoxicidade, enquanto que o hidrogel de PVP/PEG/ágar com NPAg foi o que apresentou maior índice de citotoxicidade para diluições até $90 \%$, superado apenas pelo mesmo hidrogel sem prata, para diluições acima de 90\%, que alcançou um índice de pouco mais de 35\%. Entretanto, os testes de citotoxicidade mostraram que nenhum dos hidrogéis apresentou efeito citotóxico, tendo em vista que nenhuma das concentrações dos extratos dos hidrogéis sintetizados alcançou índice de $50 \%\left(\mathrm{IC}_{50 \%}\right)$, ou seja, índice a partir do qual o material é considerado citotóxico, indicando que $50 \%$ ou mais das células sofreram lise. 


\section{CONCLUSÕES}

- Os modelos obtidos para fração gel e intumescimento mostram que planejamento de mistura é uma ótima ferramenta e pode fornecer resultados confiáveis.

- O planejamento de mistura dos hidrogéis estudados indicou importantes interações entre seus componentes.

- As concentrações dos componentes das misturas podem exercer importantes influências em todas as propriedades estudadas.

- A adição de PEG e glicerol aos hidrogéis de PVP interferem na reticulação destes, porém pode melhorar consideravelmente outras propriedades.

- Os resultados sugerem que o ágar forma redes semi-interpenetrante (SIPN) e enxertia melhorando suas propriedades físicas e físico-químicas.

- Hidrogéis de PVA apresentam melhores propriedades mecânicas do que hidrogéis de PVP com a mesma concentração do polímero base.

- Ensaios de tensão $x$ deformação de engenharia não se mostraram adequados para obtenção de dados para análise estatística das propriedades mecânicas de hidrogéis.

- É aconselhavel que os hidrogéis sejam preparados em sistema fechado, evitando perda de água e, consequentemente, alteração das formulações propostas, assim como melhoria na sua reprodutibilidade. 
- Os hidrogéis otimizados apresentaram potencial para uso como curativo de ferimentos e queimaduras, porém a otimização a partir de todas as propriedades estudadas não forneceu a composição de hidrogéis com propriedades ideais, tendo em vista os resultados dos estudos de propriedades mecânicas.

- Ìons $\mathrm{Ag}^{+}$podem ser eficientemente reduzidos por irradiação gama, em blendas de PVP com PEG, glicerol e ágar, sendo num processo eficaz para a preparação de hidrogéis com síntese simultânea de NPAg.

- Os hidrogéis de PVP com NPAg não apresentaram liberação, entretanto apresentaram propriedades antimicrobianas para $S$. aureus e $P$. aeruginosa.

- O hidrogel de PVA com NPAg não apresentou liberação de NPAg, porém apresentou atividade antimicrobiana para $S$. aureus e retardou o crescimento de $P$. aeruginosa, assim como o mesmo hidrogel sem prata.

- Os hidrogéis otimizados à base de PVP com NPAg apresentaram potencial para uso em ferimentos e queimaduras infectados. 


\section{SUGESTÕES DE TRABALHOS FUTUROS}

- Desenvolver processo laboratorial para obtenção de misturas com melhor controle, reprodutibilidade e menor variabilidade.

- Estudar, qualitativamente e quantitativamente, o uso de antiespumantes para processamento de hidrogéis sem bolhas, assim como a citotoxicidade destes.

- Reavaliar as propriedades mecânicas dos sistemas estudados, porém com limites mais estreitos, com monitoramento e correção de área da seção transversal dos corpos de prova e da região deformada, para obtenção de regressões com maior confiabilidade, ou utilizando outra metodologia.

- Efetuar estudos sistemáticos para avaliar:

$\checkmark$ o intumescimento com soluções de diferentes pHs e soluções iônicas que possam simular fluidos corpóreos.

$\checkmark$ a capacidade adesiva dos hidrogéis.

$\checkmark$ a permeabilidade ao vapor de água (WVTR) em hidrogéis com e sem NPAg.

- Efetuar novos estudos para confirmar a formação de rede SIPN e enxertia nas blendas.

- Avaliar a concentração mínima inibitória de NPAg.

- Estudar a estabilidade e atividade bactericida das NPAg em diversas condições.

- Avaliar a genotoxicidade dos hidrogéis com NPAg.

- Estudar a atividade antibacteriana contra bactérias resistentes. 


\section{APÊNDICE}

\section{APÊNDICE A - Análise estatística - Fração gel}

TABELA A 1.1 - ANOVA da regressão para o modelo quadrático da regressão de fração gel para o sistema PVP/PEG/ágar.

\begin{tabular}{lrrrrr}
\hline \multicolumn{1}{c}{$\begin{array}{c}\text { Fonte de } \\
\text { variação }\end{array}$} & $\begin{array}{c}\text { Soma } \\
\text { quadrática }\end{array}$ & $\begin{array}{c}\text { Grau de } \\
\text { liberdade }\end{array}$ & $\begin{array}{c}\text { Média } \\
\text { quadrática }\end{array}$ & razão F & valor $\mathrm{p}$ \\
\hline Modelo & 4040,84 & 9 & 448,98 & 86,42 & $<0,0001$ \\
Mistura linear & 3482,38 & 3 & 1160,79 & 223,43 & $<0,0001$ \\
$\mathrm{X}_{1} \mathrm{x}_{2}$ & 1,27 & 1 & 1,27 & 0,24 & 0,6314 \\
$\mathrm{X}_{1} \mathrm{x}_{3}$ & 12,04 & 1 & 12,04 & 2,32 & 0,1589 \\
$\mathrm{X}_{1} \mathrm{x}_{4}$ & 233,84 & 1 & 233,84 & 45,01 & $<0,0001$ \\
$\mathrm{X}_{2} \mathrm{X}_{3}$ & 7,95 & 1 & 7,95 & 1,53 & 0,2442 \\
$\mathrm{X}_{2} \mathrm{X}_{4}$ & 24,75 & 1 & 24,75 & 4,76 & 0,0540 \\
$\mathrm{X}_{3} \mathrm{X}_{4}$ & 11,82 & 1 & 11,82 & 2,28 & 0,1623 \\
Resíduo & 51,95 & 10 & 5,20 & & \\
Total corrigido & 4092,79 & 19 & & & \\
\hline Erro do modelo $= \pm 2,28 \%$ & $\mathrm{R}^{2}$ aj. $=0,9759$ & &
\end{tabular}

TABELA A 1.2 - Coeficientes reais, em percentual, estimados para a regressão de fração gel para o sistema PVP/PEG/ágar.

\begin{tabular}{|c|c|c|c|c|c|}
\hline Variável & $\begin{array}{c}\text { Coeficiente } \\
\text { Real }\end{array}$ & $\begin{array}{l}\text { Grau de } \\
\text { liberdade }\end{array}$ & Erro padrão & valor $\mathrm{t}$ & valor $p$ \\
\hline$x_{1}$ & $-8,76$ & 1 & 4,36 & 200,9885 & \\
\hline$x_{2}$ & 38,64 & 1 & 95,12 & 40,6216 & * \\
\hline$x_{3}$ & 352,57 & 1 & 1172,89 & 30,0601 & \\
\hline$X_{4}$ & 0,59 & 1 & 2,69 & 21,9145 & \\
\hline$x_{1} x_{2}$ & $-11,16$ & 1 & 118,89 & 9,3862 & 0,6314 \\
\hline$x_{1} x_{3}$ & 363,92 & 1 & 1260,08 & 28,8805 & 0,1589 \\
\hline $\mathrm{X}_{1} \mathrm{X}_{4}$ & 14,02 & 1 & 11,02 & 127,2532 & $<0,0001$ \\
\hline$x_{2} x_{3}$ & 296,28 & 1 & 1262,22 & 23,4729 & 0,2442 \\
\hline$x_{2} X_{4}$ & $-49,10$ & 1 & 118,58 & 41,4064 & 0,0540 \\
\hline $\mathrm{X}_{3} \mathrm{X}_{4}$ & 359,44 & 1 & 1256,01 & 28,6178 & 0,1623 \\
\hline
\end{tabular}

* Para os coeficientes lineares a ANOVA mostrou conjuntamente um valor de $p<$ 0,0001 baseado no valor de f, com G.L. 4 e 10.

$\mathrm{O}$ valor de $\mathrm{p}$ foi estimado por meio do valor $\mathrm{t}$ com o número de G.L. do erro residual. 
TABELA A 2.1 - ANOVA da regressão para o modelo quadrático da regressão de fração gel para o sistema PVP/glicerol/ágar.

\begin{tabular}{|c|c|c|c|c|c|}
\hline Fonte de variação & $\begin{array}{c}\text { Soma } \\
\text { quadrática }\end{array}$ & $\begin{array}{l}\text { Grau de } \\
\text { liberdade }\end{array}$ & $\begin{array}{c}\text { Média } \\
\text { quadrática }\end{array}$ & razão $F$ & valor $p$ \\
\hline Modelo & 2269,37 & 9 & 252,15 & 105,26 & $<0,0001$ \\
\hline Mistura linear & 2011,76 & 3 & 670,59 & 279,94 & $<0,0001$ \\
\hline$x_{1} x_{2}$ & 10,37 & 1 & 10,37 & 4,33 & 0,0761 \\
\hline$x_{1} x_{3}$ & 6,58 & 1 & 6,58 & 2,75 & 0,1414 \\
\hline$x_{1} x_{4}$ & 3,43 & 1 & 3,43 & 1,43 & 0,2707 \\
\hline $\mathrm{x}_{2} \mathrm{x}_{3}$ & 6,54 & 1 & 6,54 & 2,73 & 0,1426 \\
\hline $\mathrm{x}_{2} \mathrm{x}_{4}$ & 4,52 & 1 & 4,52 & 1,89 & 0,2119 \\
\hline$x_{3} x_{4}$ & 7,68 & 1 & 7,68 & 3,21 & 0,1164 \\
\hline Resíduo & 16,77 & 7 & 2,40 & & \\
\hline Falta de ajuste & 9,92 & 6 & 1,65 & $0,24^{*}$ & 0,9121 \\
\hline Erro puro & 6,85 & 1 & 6,85 & & \\
\hline Total corrigido & 2286,14 & 16 & & & \\
\hline
\end{tabular}

TABELA A 2.2 - Coeficientes reais, em percentual, estimados para a regressão de fração gel para o sistema PVP/glicerol /ágar.

\begin{tabular}{lrrrrr}
\hline Variável & $\begin{array}{c}\text { Coeficiente } \\
\text { Real }\end{array}$ & $\begin{array}{c}\text { Grau de } \\
\text { liberdade }\end{array}$ & erro padrão & valor $t$ & valor $\mathrm{p}$ \\
\hline $\mathrm{x}_{1}$ & $-1,95$ & 1 & 4,04 & 48,1807 & \\
$\mathrm{x}_{2}$ & $-59,38$ & 1 & 193,67 & 30,6582 & $*$ \\
$\mathrm{x}_{3}$ & 480,28 & 1 & 1655,09 & 29,0187 & \\
$\mathrm{x}_{4}$ & 0,91 & 1 & 1,31 & 69,1985 & \\
$\mathrm{X}_{1} \mathrm{x}_{2}$ & 79,02 & 1 & 244,11 & 32,3698 & 0,0761 \\
$\mathrm{x}_{1} \mathrm{x}_{3}$ & 443,52 & 1 & 1719,66 & 25,7910 & 0,1414 \\
$\mathrm{x}_{1} \mathrm{x}_{4}$ & 3,84 & 1 & 20,65 & 18,6087 & 0,2707 \\
$\mathrm{x}_{2} \mathrm{X}_{3}$ & 412,24 & 1 & 1603,79 & 25,7041 & 0,1426 \\
$\mathrm{x}_{2} \mathrm{X}_{4}$ & 55,30 & 1 & 258,68 & 21,3775 & 0,2119 \\
$\mathrm{X}_{3} \mathrm{X}_{4}$ & $-499,90$ & 1 & 1793,67 & 27,8700 & 0,1164 \\
\hline
\end{tabular}

* Para os coeficientes lineares a ANOVA mostrou conjuntamente um valor de $p<$ 0,0001 baseado no valor de f, com G.L. 4 e 10.

$\mathrm{O}$ valor de $\mathrm{p}$ foi estimado por meio do valor $\mathrm{t}$ com o numero de G.L. do erro residual. 
TABELA A 3.1 - ANOVA da regressão para o modelo linear da regressão de fração gel para o sistema PVA/KC/ágar

\begin{tabular}{lrrccr}
\hline $\begin{array}{c}\text { Fonte de } \\
\text { variação }\end{array}$ & $\begin{array}{c}\text { Soma } \\
\text { quadrática }\end{array}$ & $\begin{array}{c}\text { Grau de } \\
\text { liberdade }\end{array}$ & $\begin{array}{c}\text { Média } \\
\text { quadrática }\end{array}$ & razão $F$ & valor $p$ \\
\hline Modelo & 235,85 & 3 & 78,62 & 17,28 & $<0,0001$ \\
Mistura linear & 235,85 & 3 & 78,62 & 17,28 & $<0,0001$ \\
Resíduo & 63,69 & 14 & 4,55 & & \\
Total corrigido & 299,53 & 17 & & & \\
\hline
\end{tabular}

Erro do modelo $= \pm 2,13 \% \quad R^{2}$ aj. $=0,7418$

TABELA A 3.2 - Coeficientes reais, em percentual, estimados para a regressão de fração gel para o sistema PVA/KC/ágar.

\begin{tabular}{cccccc}
\hline Variável & $\begin{array}{c}\text { Coeficiente } \\
\text { Real }\end{array}$ & $\begin{array}{c}\text { Grau de } \\
\text { liberdade }\end{array}$ & erro padrão & valor $\mathrm{t}$ & valor $\mathrm{p}$ \\
\hline $\mathrm{x}_{1}$ & 1,24 & 1 & 1,47 & 1,47 & \\
$\mathrm{x}_{2}$ & $-5,98$ & 1 & 16,39 & 16,39 & $*$ \\
$\mathrm{x}_{3}$ & $-4,91$ & 1 & 15,04 & 15,04 & \\
$\mathrm{x}_{4}$ & 0,91 & 1 & 1,34 & 1,34 & \\
\hline
\end{tabular}

* Para os coeficientes lineares a ANOVA mostrou conjuntamente um valor de $p<$ 0,0001 baseado no valor de f, com G.L. 4.

$\mathrm{O}$ valor de $\mathrm{p}$ foi estimado por meio do valor $\mathrm{t}$ com o numero de G.L. do erro residual. 


\section{APÊNDICE B - Análise estatística - Intumescimento no equilíbrio}

TABELA B 1.1 - ANOVA da regressão para o modelo quadrático da regressão de intumescimento para o sistema PVP/PEG/ágar.

\begin{tabular}{lccrrr}
\hline \multicolumn{1}{c}{$\begin{array}{c}\text { Fonte de } \\
\text { variação }\end{array}$} & $\begin{array}{c}\text { Soma } \\
\text { quadrática }\end{array}$ & $\begin{array}{c}\text { Grau de } \\
\text { liberdade }\end{array}$ & $\begin{array}{c}\text { Média } \\
\text { quadrática }\end{array}$ & razão F & valor $\mathrm{p}$ \\
\hline Modelo & $2,544 \times 10^{5}$ & 9 & 28263,05 & 180,47 & $<0,0001$ \\
Mistura linear & $2,363 \times 10^{5}$ & 3 & 78750,88 & 502,86 & $<0,0001$ \\
$\mathrm{X}_{1} \mathrm{x}_{2}$ & 693,64 & 1 & 693,64 & 4,43 & 0,0892 \\
$\mathrm{X}_{1} \mathrm{x}_{3}$ & 1640,52 & 1 & 1640,52 & 10,48 & 0,0230 \\
$\mathrm{X}_{1} \mathrm{X}_{4}$ & 663,64 & 1 & 663,76 & 4,24 & 0,0946 \\
$\mathrm{X}_{2} \mathrm{X}_{3}$ & 2120,91 & 1 & 2120,91 & 13,54 & 0,0143 \\
$\mathrm{X}_{2} \mathrm{X}_{4}$ & 773,81 & 1 & 773,81 & 4,94 & 0,0769 \\
$\mathrm{X}_{3} \mathrm{X}_{4}$ & 1382,11 & 1 & 1382,11 & 8,83 & 0,0311 \\
Resíduo & 783,03 & 5 & 156,61 & & \\
Total corrigido & $2,552 \times 10^{5}$ & 14 & & & \\
\hline
\end{tabular}

Erro do modelo $= \pm 12,51 \% \quad R^{2}$ aj. $=0,9914$

TABELA B 1.2 - Coeficientes reais, em percentual, estimados para a regressão de intumescimento para o sistema PVP/PEG/ágar.

\begin{tabular}{crrrrr}
\hline Variável & $\begin{array}{c}\text { Coeficiente } \\
\text { Real }\end{array}$ & $\begin{array}{c}\text { Grau de } \\
\text { liberdade }\end{array}$ & erro padrão & valor t & valor $\mathrm{p}$ \\
\hline $\mathrm{x}_{1}$ & 38,32 & 1 & 23,86 & 160,5859 & \\
$\mathrm{x}_{2}$ & $-266,91$ & 1 & 570,85 & 46,7572 & $*$ \\
$\mathrm{x}_{3}$ & $4,90 \times 10^{3}$ & 1 & 7964,96 & 61,5031 & \\
$\mathrm{X}_{4}$ & $-0,27$ & 1 & 15,41 & 1,7477 & \\
$\mathrm{X}_{1} \mathrm{x}_{2}$ & 303,25 & 1 & 740,52 & 40,9505 & 0,0892 \\
$\mathrm{X}_{1} \mathrm{x}_{3}$ & $-5,43 \times 10^{3}$ & 1 & 8627.50 & 62,9777 & 0,0230 \\
$\mathrm{X}_{1} \mathrm{X}_{4}$ & $-27,99$ & 1 & 69,88 & 40,0610 & 0,0946 \\
$\mathrm{X}_{2} \mathrm{X}_{3}$ & $-6,00 \times 10^{3}$ & 1 & 8382,17 & 71,6068 & 0,0143 \\
$\mathrm{X}_{2} \mathrm{X}_{4}$ & 317,12 & 1 & 733,19 & 43,2526 & 0,0769 \\
$\mathrm{X}_{3} \mathrm{X}_{4}$ & $-4,96 \times 10^{3}$ & 1 & 8577,84 & 57,8048 & 0,0311 \\
\hline
\end{tabular}

* Para os coeficientes lineares a ANOVA mostrou conjuntamente um valor de $p<$ 0,0001 baseado no valor de f, com G.L. 4 e 10.

$\mathrm{O}$ valor de $\mathrm{p}$ foi estimado por meio do valor $\mathrm{t}$ com o numero de G.L. do erro residual. 
TABELA B 2.1 - ANOVA da regressão para o modelo quadrático da regressão de intumescimento para o sistema PVP/glicerol/ágar.

\begin{tabular}{lccrrr}
\hline \multicolumn{1}{c}{$\begin{array}{c}\text { Fonte de } \\
\text { variação }\end{array}$} & $\begin{array}{c}\text { Soma } \\
\text { quadrática }\end{array}$ & $\begin{array}{c}\text { Grau de } \\
\text { liberdade }\end{array}$ & $\begin{array}{c}\text { Média } \\
\text { quadrática }\end{array}$ & razão $F$ & valor $\mathrm{p}$ \\
\hline Modelo & $1,202 \times 10^{5}$ & 9 & 13352,13 & 777,77 & $<0,0001$ \\
Mistura linear & $1,101 \times 10^{5}$ & 3 & 36684,24 & 2136,89 & $<0,0001$ \\
$\mathrm{x}_{1} \mathrm{x}_{2}$ & 546,17 & 1 & 546,17 & 31,81 & 0,0110 \\
$\mathrm{X}_{1} \mathrm{X}_{3}$ & 471,74 & 1 & 471,74 & 27,48 & 0,0135 \\
$\mathrm{X}_{1} \mathrm{x}_{4}$ & 3384,26 & 1 & 3384,26 & 197,14 & 0,0008 \\
$\mathrm{X}_{2} \mathrm{X}_{3}$ & 213,49 & 1 & 213,49 & 12,44 & 0,0387 \\
$\mathrm{X}_{2} \mathrm{x}_{4}$ & 852,82 & 1 & 852,82 & 49,68 & 0,0059 \\
$\mathrm{X}_{3} \mathrm{X}_{4}$ & 398,75 & 1 & 398,75 & 23,23 & 0,0170 \\
Resíduo & 51,50 & 3 & 17,17 & & \\
Falta de ajuste & 23,82 & 2 & 11,91 & $0,43^{*}$ & 0,7331 \\
Erro puro & 27,68 & 1 & 27,68 & & \\
Total corrigido & $1,202 \times 10^{5}$ & 12 & & & \\
\hline
\end{tabular}

Erro do modelo $= \pm 4,14 \%$

$R^{2}$ aj. $=0,9983$

* insignificante

TABELA B 2.2 - Coeficientes reais, em percentual, estimados para a regressão de intumescimento para o sistema PVP/glicerol/ágar.

\begin{tabular}{crrrrr}
\hline Variável & $\begin{array}{c}\text { Coeficiente } \\
\text { Real }\end{array}$ & $\begin{array}{c}\text { Grau de } \\
\text { liberdade }\end{array}$ & $\begin{array}{r}\text { erro } \\
\text { padrão }\end{array}$ & valor $t$ & valor $p$ \\
\hline$x_{1}$ & 86,07 & 1 & 9,52 & 904,0752 & \\
$x_{2}$ & $-1,08 \times 10^{3}$ & 1 & 999,31 & $-107,9345$ & $*$ \\
$x_{3}$ & $4,18 \times 10^{3}$ & 1 & 5521,35 & 75,7030 & \\
$x_{4}$ & 0,53 & 1 & 6,40 & 8,4199 & \\
$x_{1} x_{2}$ & $1,14 \times 10^{3}$ & 1 & 1296,00 & 87,7701 & 0,0110 \\
$x_{1} x_{3}$ & $-4,89 \times 10^{3}$ & 1 & 5989,26 & $-81,5727$ & 0,0135 \\
$x_{1} x_{4}$ & $-90,57$ & 1 & 41,46 & $-218,4658$ & 0,0008 \\
$x_{2} x_{3}$ & $-3,91 \times 10^{3}$ & 1 & 7121,20 & $-54,8756$ & 0,0387 \\
$x_{2} x_{4}$ & $1,16 \times 10^{3}$ & 1 & 1057,36 & 109,6788 & 0,0059 \\
$x_{3} x_{4}$ & $-4,24 \times 10^{3}$ & 1 & 5657,15 & $-74,9971$ & 0,0170 \\
\hline
\end{tabular}

* Para os coeficientes lineares a ANOVA mostrou conjuntamente um valor de $p<$ 0,0001 baseado no valor de f, com G.L. 4 e 10.

$\mathrm{O}$ valor de $\mathrm{p}$ foi estimado por meio do valor $\mathrm{t}$ com o numero de G.L. do erro residual. 
TABELA B 3.1 - ANOVA da regressão para o modelo quadrático da regressão de intumescimento para o sistema PVA/KC/ágar.

\begin{tabular}{lrrrrr}
\hline \multicolumn{1}{c}{$\begin{array}{c}\text { Fonte de } \\
\text { variação }\end{array}$} & $\begin{array}{c}\text { Soma } \\
\text { quadrática }\end{array}$ & $\begin{array}{c}\text { Grau de } \\
\text { liberdade }\end{array}$ & $\begin{array}{c}\text { Média } \\
\text { quadrática }\end{array}$ & razão $F$ & valor $\mathrm{p}$ \\
\hline Modelo & $2,007 \times 10^{5}$ & 9 & 22297,01 & 192,55 & 0,0006 \\
Mistura linear & $1,861 \times 10^{5}$ & 3 & 62033,95 & 535,70 & 0,0001 \\
$\mathrm{x}_{1} \mathrm{X}_{2}$ & 764,72 & 1 & 764,72 & 6,60 & 0,0825 \\
$\mathrm{X}_{1} \mathrm{x}_{3}$ & 1457,26 & 1 & 1457,26 & 12,58 & 0,0382 \\
$\mathrm{X}_{1} \mathrm{x}_{4}$ & 90,35 & 1 & 90,35 & 0,78 & 0,4421 \\
$\mathrm{x}_{2} \mathrm{X}_{3}$ & 1771,92 & 1 & 1771,92 & 15,30 & 0,0297 \\
$\mathrm{X}_{2} \mathrm{x}_{4}$ & 778,07 & 1 & 778,07 & 6,72 & 0,0809 \\
$\mathrm{X}_{3} \mathrm{X}_{4}$ & 1502,24 & 1 & 1502,24 & 12,97 & 0,0367 \\
Resíduo & 347,40 & 3 & 115,80 & & \\
Total corrigido & $2,01 \times 10^{5}$ & 12 & & & \\
\hline
\end{tabular}

$$
\text { Erro do modelo }= \pm 10,76 \% \quad R^{2} \text { aj. }=0,9931
$$

TABELA B 3.2 - Coeficientes reais, em percentual, estimados para a regressão de intumescimento para o sistema PVA/KC/ágar.

\begin{tabular}{lrrrrr}
\hline Variável & $\begin{array}{c}\text { Coeficiente } \\
\text { Real }\end{array}$ & $\begin{array}{c}\text { Grau de } \\
\text { liberdade }\end{array}$ & erro padrão & valor t & valor $p$ \\
\hline$x_{1}$ & $-61,36$ & 1 & 23,61 & 259,90 & \\
$x_{2}$ & $-3,46 \times 10^{4}$ & 1 & 20540,84 & 168,54 & $*$ \\
$x_{3}$ & $43,25 \times 10^{4}$ & 1 & 18192,33 & 237,72 & \\
$x_{4}$ & $-2,68$ & 1 & 10,71 & 25,06 & \\
$x_{1} x_{2}$ & $3,53 \times 10^{4}$ & 1 & 22701,59 & 155,41 & 0,0825 \\
$x_{1} x_{3}$ & $-4,36 \times 10^{4}$ & 1 & 20328,56 & 214,53 & 0,0382 \\
$x_{1} x_{4}$ & 100,95 & 1 & 189,01 & 53,41 & 0,4421 \\
$x_{2} x_{3}$ & $-1,61 \times 10^{4}$ & 1 & 6819,68 & 236,52 & 0,0297 \\
$x_{2} x_{4}$ & $3,52 \times 10^{4}$ & 1 & 22443,08 & 156,75 & 0,0809 \\
$x_{3} x_{4}$ & $-4,36 \times 10^{4}$ & 1 & 20005,75 & 217,79 & 0,0367 \\
\hline
\end{tabular}

* Para os coeficientes lineares a ANOVA mostrou conjuntamente um valor de $p=$ 0,0006 baseado no valor de f, com G.L. 4 e 10.

$\mathrm{O}$ valor de $\mathrm{p}$ foi estimado por meio do valor $\mathrm{t}$ com o numero de G.L. do erro residual. 


\section{APÊNDICE C - Análise estatística - Resistência à tensão}

TABELA C 1.1 - ANOVA da regressão para o modelo quadrático da regressão de resistência à tensão para o sistema PVP/PEG/ágar.

\begin{tabular}{lrrrrr}
\hline \multicolumn{1}{c}{$\begin{array}{c}\text { Fonte de } \\
\text { variação }\end{array}$} & $\begin{array}{c}\text { Soma } \\
\text { quadrática }\end{array}$ & $\begin{array}{c}\text { Grau de } \\
\text { liberdade }\end{array}$ & $\begin{array}{c}\text { Média } \\
\text { quadrática }\end{array}$ & razão F & valor $\mathrm{p}$ \\
\hline Modelo & 18027,82 & 9 & 2003,09 & 49,40 & $<0,0001$ \\
Mistura linear & 15321,99 & 3 & 5107,33 & 125,96 & $<0,0001$ \\
$\mathrm{X}_{1} \mathrm{X}_{2}$ & 442,66 & 1 & 442,66 & 10,92 & 0,0108 \\
$\mathrm{X}_{1} \mathrm{x}_{3}$ & 76,70 & 1 & 76,70 & 1,89 & 0,2063 \\
$\mathrm{X}_{1} \mathrm{x}_{4}$ & 24,94 & 1 & 24,94 & 0,61 & 0,4555 \\
$\mathrm{X}_{2} \mathrm{X}_{3}$ & 11,58 & 1 & 11,58 & 0,29 & 0,6076 \\
$\mathrm{X}_{2} \mathrm{X}_{4}$ & 492,85 & 1 & 429,85 & 10,60 & 0,0116 \\
$\mathrm{X}_{3} \mathrm{X}_{4}$ & 42,59 & 1 & 42,59 & 1,05 & 0,3354 \\
Resíduo & 324,39 & 8 & 40,55 & & \\
Total corrigido & 18352,21 & 17 & & & \\
\hline
\end{tabular}

Erro do modelo $= \pm 6,37 \% \quad R^{2}$ aj. $=0,9623$

TABELA C 1.2 - Coeficientes reais, em percentual, estimados para a regressão de tensão para o sistema PVP/PEG/ágar.

\begin{tabular}{lrrrrc}
\hline Variável & $\begin{array}{c}\text { Coeficiente } \\
\text { Real }\end{array}$ & $\begin{array}{c}\text { Grau de } \\
\text { liberdade }\end{array}$ & erro padrão & valor t & valor $\mathrm{p}$ \\
\hline $\mathrm{x}_{1}$ & $-4,02$ & 1 & 12,85 & 31,3004 & \\
$\mathrm{x}_{2}$ & 224,32 & 1 & 299,54 & 74,8865 & $*$ \\
$\mathrm{x}_{3}$ & $-80,79$ & 1 & 3977,13 & 20,3143 & \\
$\mathrm{X}_{4}$ & 0,05 & 1 & 8,45 & 0,6016 & \\
$\mathrm{X}_{1} \mathrm{x}_{2}$ & $-241,16$ & 1 & 384,76 & 62,6771 & 0,0108 \\
$\mathrm{x}_{1} \mathrm{x}_{3}$ & $1,11 \times 10^{3}$ & 1 & 4263,24 & 26,0905 & 0,2063 \\
$\mathrm{X}_{1} \mathrm{x}_{4}$ & 5,19 & 1 & 34,87 & 0,1422 & 0,4555 \\
$\mathrm{X}_{2} \mathrm{X}_{3}$ & 423,56 & 1 & 4177,75 & 10,1385 & 0,6076 \\
$\mathrm{X}_{2} \mathrm{X}_{4}$ & $-233,77$ & 1 & 378,50 & 61,7630 & 0,0116 \\
$\mathrm{X}_{3} \mathrm{X}_{4}$ & 823,47 & 1 & 4235,65 & 19,4415 & 0,3354 \\
\hline
\end{tabular}

* Para os coeficientes lineares a ANOVA mostrou conjuntamente um valor de $p<$ 0,0001 baseado no valor de f, com G.L. 4 e 10.

$\mathrm{O}$ valor de $\mathrm{p}$ foi estimado por meio do valor $\mathrm{t}$ com o numero de G.L. do erro residual. 
TABELA C 2.1 - ANOVA da regressão para o modelo quadrático da regressão de tensão para o sistema PVP/glicerol/ágar.

\begin{tabular}{|c|c|c|c|c|c|}
\hline $\begin{array}{l}\text { Fonte de } \\
\text { variação }\end{array}$ & $\begin{array}{c}\text { Soma } \\
\text { quadrática }\end{array}$ & $\begin{array}{l}\text { Grau de } \\
\text { liberdade }\end{array}$ & $\begin{array}{c}\text { Média } \\
\text { quadrática }\end{array}$ & razão F & valor $p$ \\
\hline Modelo & 27759,96 & 9 & 3084,44 & 40,76 & 0,0001 \\
\hline Mistura linear & 21504,45 & 3 & 7168,15 & 94,73 & $<0,0001$ \\
\hline$x_{1} x_{2}$ & 150,18 & 1 & 150,18 & 1,98 & 0,2085 \\
\hline$x_{1} x_{3}$ & 13,89 & 1 & 13,89 & 0,18 & 0,6833 \\
\hline$x_{1} x_{4}$ & 439,74 & 1 & 439,74 & 5,81 & 0,0525 \\
\hline$x_{2} x_{3}$ & 2,00 & 1 & 2,00 & 0,026 & 0,8762 \\
\hline$x_{2} x_{4}$ & 61,11 & 1 & 61,11 & 0,81 & 0,4034 \\
\hline$x_{3} x_{4}$ & 1,98 & 1 & 1,98 & 0,026 & 0,8767 \\
\hline Resíduo & 454,00 & 6 & 75,67 & & \\
\hline Falta de ajuste & 347,42 & 5 & 69,48 & 0,65 & 0,7295 * \\
\hline Erro puro & 106,58 & 1 & 106,58 & & \\
\hline Total corrigido & 28213,96 & 15 & & & \\
\hline $\mathrm{E}$ & $0 \%$ & $R^{2}$ & 598 & 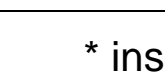 & ante \\
\hline
\end{tabular}

TABELA C 2.2 - Coeficientes reais, em percentual, estimados para a regressão de tensão para o sistema PVP/glicerol/ágar.

\begin{tabular}{|c|c|c|c|c|c|}
\hline Variável & $\begin{array}{c}\text { Coeficiente } \\
\text { Real }\end{array}$ & $\begin{array}{l}\text { Grau de } \\
\text { liberdade }\end{array}$ & erro padrão & valor t & valor $p$ \\
\hline$x_{1}$ & $-15,01$ & 1 & 47,43 & 31,6401 & \\
\hline$x_{2}$ & 98,95 & 1 & 482,28 & 20,5180 & * \\
\hline$x_{3}$ & - 157,70 & 1 & 6423,53 & 2,4550 & \\
\hline$x_{4}$ & $-0,51$ & 1 & 8,60 & 5,8907 & \\
\hline$x_{1} x_{2}$ & - 150,87 & 1 & 687,65 & 21,9403 & 0,208 \\
\hline$x_{1} x_{3}$ & 469,90 & 1 & 7043,05 & 6,6718 & 0,683 \\
\hline$x_{1} x_{4}$ & 21,97 & 1 & 58,51 & 37,5430 & 0,052 \\
\hline$x_{2} x_{3}$ & - 169,09 & 1 & 6680,66 & 2,5310 & 0,876 \\
\hline $\mathrm{X}_{2} \mathrm{X}_{4}$ & - 87,95 & 1 & 628,41 & 13,9958 & 0,403 \\
\hline$x_{3} x_{4}$ & 174,97 & 1 & 6938,60 & 2,5217 & 0,876 \\
\hline
\end{tabular}

* Para os coeficientes lineares a ANOVA mostrou conjuntamente um valor de $p=$ 0,0001 baseado no valor de f, com G.L. 4 e 10.

$\mathrm{O}$ valor de $\mathrm{p}$ foi estimado por meio do valor $\mathrm{t}$ com o numero de G.L. do erro residual. 
TABELA C 3.1 - ANOVA da regressão para o modelo quadrático da regressão de tensão para o sistema PVA/KC/ágar.

\begin{tabular}{lrrrrr}
\hline \multicolumn{1}{c}{$\begin{array}{c}\text { Fonte de } \\
\text { variação }\end{array}$} & \multicolumn{1}{c}{$\begin{array}{c}\text { Soma } \\
\text { quadrática }\end{array}$} & $\begin{array}{c}\text { Grau de } \\
\text { liberdade }\end{array}$ & $\begin{array}{c}\text { Média } \\
\text { quadrática }\end{array}$ & razão $F$ & valor $\mathrm{p}$ \\
\hline Modelo & 10533,04 & 9 & 1170,34 & 33,32 & 0,0006 \\
Mistura linear & 9931,87 & 3 & 3310,62 & 94,26 & $<0,0001$ \\
$\mathrm{x}_{1} \mathrm{X}_{2}$ & 177,27 & 1 & 177,27 & 5,05 & 0,0746 \\
$\mathrm{X}_{1} \mathrm{X}_{3}$ & 118,93 & 1 & 118,93 & 3,39 & 0,1251 \\
$\mathrm{x}_{1} \mathrm{X}_{4}$ & 42,71 & 1 & 42,71 & 1,22 & 0,3204 \\
$\mathrm{X}_{2} \mathrm{X}_{3}$ & 46,13 & 1 & 46,13 & 1,31 & 0,3037 \\
$\mathrm{X}_{2} \mathrm{X}_{4}$ & 198,19 & 1 & 198,10 & 5,64 & 0,0635 \\
$\mathrm{X}_{3} \mathrm{X}_{4}$ & 115,50 & 1 & 115,50 & 3,29 & 0,1295 \\
Resíduo & 175,62 & 5 & 35,12 & & \\
Total corrigido & 10708,66 & 14 & & & \\
\hline
\end{tabular}

Erro do modelo $= \pm 5,58 \% \quad R^{2}$ aj. $=0,9541$

TABELA C 3.2 - Coeficientes reais, em percentual, estimados para a regressão de tensão para o sistema PVA/KC/ágar.

\begin{tabular}{lrrrrc}
\hline Variável & $\begin{array}{c}\text { Coeficiente } \\
\text { Real }\end{array}$ & $\begin{array}{c}\text { Grau de } \\
\text { liberdade }\end{array}$ & erro padrão & valor $\mathrm{v}$ & valor $\mathrm{p}$ \\
\hline $\mathrm{x}_{1}$ & $-10,08$ & 1 & 8,24 & 122,2973 & \\
$\mathrm{x}_{2}$ & $3,96 \times 10^{3}$ & 1 & 2538,25 & 30,0601 & $*$ \\
$\mathrm{x}_{3}$ & $-3,02 \times 10^{3}$ & 1 & 2576,74 & 117,1635 & \\
$\mathrm{x}_{4}$ & $-0,18$ & 1 & 5,74 & 3,0505 & \\
$\mathrm{x}_{1} \mathrm{x}_{2}$ & $-3,79 \times 10^{3}$ & 1 & 2783,86 & 136,0341 & 0,0746 \\
$\mathrm{x}_{1} \mathrm{x}_{3}$ & $3,15 \times 10^{3}$ & 1 & 2826,49 & 111,4456 & 0,1251 \\
$\mathrm{x}_{1} \mathrm{x}_{4}$ & 15,59 & 1 & 23,34 & 66,7866 & 0,3204 \\
$\mathrm{x}_{2} \mathrm{x}_{3}$ & $-2,41 \times 10^{3}$ & 1 & 3471,36 & 69,3964 & 0,3037 \\
$\mathrm{x}_{2} \mathrm{X}_{4}$ & $-3,98 \times 10^{3}$ & 1 & 2762,91 & 143,8701 & 0,0635 \\
$\mathrm{x}_{3} \mathrm{X}_{4}$ & $3,07 \times 10^{3}$ & 1 & 2798,65 & 109,8387 & 0,1295 \\
\hline
\end{tabular}

* Para os coeficientes lineares a ANOVA mostrou conjuntamente um valor de $p<$ 0,0006 baseado no valor de f, com G.L. 4 e 10.

$\mathrm{O}$ valor de $\mathrm{p}$ foi estimado por meio do valor $\mathrm{t}$ com o numero de G.L. do erro residual. 


\section{APÊNDICE D - Análise estatística - Deformação na tração}

TABELA D 1.1 - ANOVA da regressão para o modelo quadrático da regressão de deformação na tração para o sistema PVP/PEG/ágar.

\begin{tabular}{lccrrr}
\hline \multicolumn{1}{c}{$\begin{array}{c}\text { Fonte de } \\
\text { variação }\end{array}$} & $\begin{array}{c}\text { Soma } \\
\text { quadrática }\end{array}$ & $\begin{array}{c}\text { Grau de } \\
\text { liberdade }\end{array}$ & $\begin{array}{c}\text { Média } \\
\text { quadrática }\end{array}$ & razão F & valor $\mathrm{p}$ \\
\hline Modelo & 53721,66 & 9 & 5969,07 & 39,52 & 0,0015 \\
Mistura linear & 35892,41 & 3 & 11969,14 & 79,21 & 0,0005 \\
$\mathrm{X}_{1} \mathrm{x}_{2}$ & 743,65 & 1 & 743,65 & 4,92 & 0,0907 \\
$\mathrm{X}_{1} \mathrm{X}_{3}$ & 127,05 & 1 & 127,05 & 0,84 & 0,4110 \\
$\mathrm{X}_{1} \mathrm{X}_{4}$ & 4913,89 & 1 & 4913,89 & 32,53 & 0,0047 \\
$\mathrm{X}_{2} \mathrm{X}_{3}$ & 606,11 & 1 & 606,11 & 4,01 & 0,1157 \\
$\mathrm{X}_{2} \mathrm{X}_{4}$ & 1398,15 & 1 & 1398,15 & 9,26 & 0,0383 \\
$\mathrm{X}_{3} \mathrm{X}_{4}$ & 183,20 & 1 & 183,20 & 1,21 & 0,3326 \\
Resíduo & 604,20 & 4 & 151,05 & & \\
Total corrigido & 54325,86 & 13 & & & \\
\hline
\end{tabular}

Erro do modelo $= \pm 12,29 \% \quad R^{2}$ aj. $=0,9639$

TABELA D 1.2 - Coeficientes reais, em percentual, estimados para a regressão de deformação na tração para o sistema PVP/PEG/ágar.

\begin{tabular}{lrrrrr}
\hline Variável & $\begin{array}{c}\text { Coeficiente } \\
\text { Real }\end{array}$ & $\begin{array}{c}\text { Grau de } \\
\text { liberdade }\end{array}$ & erro padrão & valor t & valor $\mathrm{p}$ \\
\hline $\mathrm{x}_{1}$ & $-59,97$ & 1 & 1044,56 & 5,7415 & \\
$\mathrm{x}_{2}$ & 458,42 & 1 & 13182,52 & 3,4775 & $*$ \\
$\mathrm{x}_{3}$ & $3,63 \times 10^{3}$ & 1 & $3,309 \times 10^{5}$ & 1,0982 & \\
$\mathrm{x}_{4}$ & $-0,81$ & 1 & 39,95 & 2,0295 & \\
$\mathrm{x}_{1} \mathrm{x}_{2}$ & $-317,80$ & 1 & 14322,70 & 2,2188 & 0,0907 \\
$\mathrm{x}_{1} \mathrm{x}_{3}$ & $-3,20 \times 10^{3}$ & 1 & $3,488 \times 10^{5}$ & 0,9171 & 0,4110 \\
$\mathrm{x}_{1} \mathrm{x}_{4}$ & 78,85 & 1 & 1382,40 & 5,7036 & 0,0047 \\
$\mathrm{x}_{2} \mathrm{X}_{3}$ & $-7,56 \times 10^{3}$ & 1 & $3,776 \times 10^{5}$ & 2,0032 & 0,1157 \\
$\mathrm{x}_{2} \mathrm{X}_{4}$ & $-424,01$ & 1 & 13936,73 & 3,0424 & 0,0383 \\
$\mathrm{x}_{3} \mathrm{X}_{4}$ & $-3,68 \times 10^{3}$ & 1 & $3,342 \times 10^{5}$ & 1,1011 & 0,3326 \\
\hline
\end{tabular}

* Para os coeficientes lineares a ANOVA mostrou conjuntamente um valor de $p=$ 0,0015 baseado no valor de f, com G.L. 4 e 10.

$\mathrm{O}$ valor de $\mathrm{p}$ foi estimado por meio do valor $\mathrm{t}$ com o numero de G.L. do erro residual. 
TABELA D 2.1 - ANOVA da regressão para o modelo linear da regressão de deformação na tração para o sistema PVP/glicerol/ágar.

\begin{tabular}{lccccc}
\hline $\begin{array}{l}\text { Fonte de } \\
\text { variação }\end{array}$ & $\begin{array}{c}\text { Soma } \\
\text { quadrática }\end{array}$ & $\begin{array}{c}\text { Grau de } \\
\text { liberdade }\end{array}$ & $\begin{array}{c}\text { Média } \\
\text { quadrática }\end{array}$ & razão $F$ & valor $p$ \\
\hline Modelo & 34735,20 & 3 & 11578,40 & 135,43 & $<0,0001$ \\
Mistura linear & 34735,20 & 3 & 11578,40 & 135,43 & $<0,0001$ \\
Resíduo & 598,44 & 7 & 85,49 & & \\
Total corrigido & 35333,64 & 10 & & & \\
\hline \multicolumn{2}{l}{ Erro do modelo $= \pm 9,25 \%$} & \multicolumn{2}{c}{$\mathrm{R}^{2}$ aj. $=0,9758$} & &
\end{tabular}

TABELA D 2.2 - Coeficientes reais, em percentual, estimados para a regressão de deformação na tração para o sistema PVP/glicerol/ágar.

\begin{tabular}{ccccrc}
\hline Variável & $\begin{array}{c}\text { Coeficiente } \\
\text { Real }\end{array}$ & $\begin{array}{c}\text { Grau de } \\
\text { liberdade }\end{array}$ & erro padrão & valor $\mathrm{t}$ & valor $\mathrm{p}$ \\
\hline $\mathrm{x}_{1}$ & $-3,47$ & 1 & 10,24 & 33,8560 & \\
$\mathrm{x}_{2}$ & 6,05 & 1 & 33,33 & 18,1424 & $*$ \\
$\mathrm{x}_{3}$ & 80,26 & 1 & 111,82 & 71,7723 & \\
$\mathrm{x}_{4}$ & 1,75 & 1 & 10,25 & 17,0887 & \\
\hline
\end{tabular}

* Para os coeficientes lineares a ANOVA mostrou conjuntamente um valor de $p<$ 0,0001 baseado no valor de f, com G.L. 4 e 10.

$\mathrm{O}$ valor de $\mathrm{p}$ foi estimado por meio do valor $\mathrm{t}$ com o numero de G.L. do erro residual. 
TABELA D 3.1 - ANOVA da regressão para o modelo quadrático da regressão de deformação na tração para o sistema PVA/KC/ágar.

\begin{tabular}{lrccrr}
\hline \multicolumn{1}{c}{$\begin{array}{c}\text { Fonte de } \\
\text { variação }\end{array}$} & \multicolumn{1}{c}{$\begin{array}{c}\text { Soma } \\
\text { quadrática }\end{array}$} & $\begin{array}{c}\text { Grau de } \\
\text { liberdade }\end{array}$ & $\begin{array}{c}\text { Média } \\
\text { quadrática }\end{array}$ & razão $F$ & valor $p$ \\
\hline Modelo & $6,275 \times 10^{5}$ & 9 & 69725,78 & 93,39 & $<0,0001$ \\
Mixtura linear & $5,761 \times 10^{5}$ & 3 & $1,902 \times 10^{5}$ & 257,20 & $<0,0001$ \\
$\mathrm{X}_{1} \mathrm{x}_{2}$ & 10232,07 & 1 & 10232,07 & 13,70 & 0,0140 \\
$\mathrm{X}_{1} \mathrm{x}_{3}$ & 10276,32 & 1 & 10276,32 & 13,76 & 0,0139 \\
$\mathrm{X}_{1} \mathrm{x}_{4}$ & 15293,88 & 1 & 15293,88 & 20,48 & 0,0062 \\
$\mathrm{X}_{2} \mathrm{X}_{3}$ & 5625,55 & 1 & 5625,55 & 7,53 & 0,0406 \\
$\mathrm{X}_{2} \mathrm{X}_{4}$ & 10206,93 & 1 & 10206,93 & 13,67 & 0,0140 \\
$\mathrm{X}_{3} \mathrm{X}_{4}$ & 10863,35 & 1 & 10863,35 & 14,55 & 0,0124 \\
Resíduo & 3733,06 & 5 & 746,61 & & \\
Total corrigido & $6,313 \times 10^{5}$ & 14 & & & \\
\hline
\end{tabular}

Erro do modelo $= \pm 27,3 \% \quad R^{2}$ aj. $=0,9834$

TABELA D 3.2 - Coeficientes reais, em percentual, estimados para a regressão de deformação na tração para o sistema PVA/KC/ágar.

\begin{tabular}{lrrrrr}
\hline Variável & $\begin{array}{c}\text { Coeficiente } \\
\text { Real }\end{array}$ & $\begin{array}{r}\text { Grau de } \\
\text { liberdade }\end{array}$ & erro padrão & valor t & valor $\mathrm{p}$ \\
\hline $\mathrm{x}_{1}$ & $-207,65$ & 1 & 49,51 & 419,4114 & \\
$\mathrm{x}_{2}$ & $-2,72 \times 10^{4}$ & 1 & 12795,23 & 212,8918 & $*$ \\
$\mathrm{x}_{3}$ & $7,58 \times 10^{4}$ & 1 & 33871,71 & 223,8151 & \\
$\mathrm{x}_{4}$ & $-6,08$ & 1 & 63,15 & 9,6238 & \\
$\mathrm{x}_{1} \mathrm{x}_{2}$ & $2,81 \times 10^{4}$ & 1 & 13689,62 & 205,4111 & 0,0140 \\
$\mathrm{x}_{1} \mathrm{x}_{3}$ & $-7,67 \times 10^{4}$ & 1 & 37197,46 & 206,3044 & 0,0139 \\
$\mathrm{x}_{1} \mathrm{x}_{4}$ & 313,22 & 1 & 124,45 & 251,6857 & 0,0062 \\
$\mathrm{x}_{2} \mathrm{x}_{3}$ & $-8,79 \times 10^{4}$ & 1 & 57568,46 & 152,6357 & 0,0406 \\
$\mathrm{x}_{2} \mathrm{X}_{4}$ & $2,80 \times 10^{4}$ & 1 & 13609,36 & 205,5938 & 0,0140 \\
$\mathrm{x}_{3} \mathrm{X}_{4}$ & $-0,76 \times 10^{4}$ & 1 & 35954,67 & 212,1282 & 0,0124 \\
\hline
\end{tabular}

* Para os coeficientes lineares a ANOVA mostrou conjuntamente um valor de $p<$ 0,0001 baseado no valor de f, com G.L. 4 e 10.

$\mathrm{O}$ valor de $\mathrm{p}$ foi estimado por meio do valor $\mathrm{t}$ com o numero de G.L. do erro residual. 


\section{APÊNDICE E - Análise estatística - Módulo elástico}

TABELA E 1.1 - ANOVA da regressão para o modelo quadrático da regressão de módulo elástico para o sistema PVP/PEG/ágar.

\begin{tabular}{lcccrr}
\hline \multicolumn{1}{c}{$\begin{array}{c}\text { Fonte de } \\
\text { variação }\end{array}$} & $\begin{array}{c}\text { Soma } \\
\text { quadrática }\end{array}$ & $\begin{array}{c}\text { Grau de } \\
\text { liberdade }\end{array}$ & $\begin{array}{c}\text { Média } \\
\text { quadrática }\end{array}$ & razão F & valor $\mathrm{p}$ \\
\hline Modelo & 70171,22 & 9 & 7796,80 & 28,54 & $<0,0001$ \\
Mistura linear & 62847,18 & 3 & 20949,06 & 76,69 & $<0,0001$ \\
$\mathrm{X}_{1} \mathrm{X}_{2}$ & 1304,71 & 1 & 1304,71 & 4,78 & 0,0537 \\
$\mathrm{X}_{1} \mathrm{X}_{3}$ & 284,60 & 1 & 284,60 & 1,04 & 0,3314 \\
$\mathrm{X}_{1} \mathrm{X}_{4}$ & 328,01 & 1 & 328,01 & 1,20 & 0,2989 \\
$\mathrm{X}_{2} \mathrm{X}_{3}$ & 1059,70 & 1 & 1059,70 & 3,88 & 0,0772 \\
$\mathrm{X}_{2} \mathrm{X}_{4}$ & 1097,64 & 1 & 1097,64 & 4,02 & 0,0728 \\
$\mathrm{X}_{3} \mathrm{X}_{4}$ & 401,99 & 1 & 401,99 & 1,47 & 0,2530 \\
Resíduo & 2731,62 & 10 & 273,16 & & \\
Total corrigido & 72902,84 & 19 & & & \\
\hline
\end{tabular}

Erro do modelo $= \pm 16,5 \% \quad R^{2}$ aj. $=0,9288$

TABELA E 1.2 - Coeficientes reais, em percentual, estimados para a regressão de módulo elástico para o sistema PVP/PEG/ágar.

\begin{tabular}{lrrrrc}
\hline Variável & $\begin{array}{c}\text { Coeficiente } \\
\text { real }\end{array}$ & $\begin{array}{c}\text { Grau de } \\
\text { liberdade }\end{array}$ & erro padrão & valor $\mathrm{r}$ & valor $\mathrm{p}$ \\
\hline $\mathrm{x}_{1}$ & $-11,79$ & 1 & 1156,36 & 1,0196 & \\
$\mathrm{x}_{2}$ & 317,42 & 1 & 15536,25 & 2,0431 & $*$ \\
$\mathrm{x}_{3}$ & $2,12 \times 10^{3}$ & 1 & $1,702 \times 10^{5}$ & 1,2430 & \\
$\mathrm{x}_{4}$ & $-0,11$ & 1 & 29,69 & 0,3863 & \\
$\mathrm{x}_{1} \mathrm{x}_{2}$ & $-357,39$ & 1 & 16353,12 & 2,1855 & 0,0537 \\
$\mathrm{x}_{1} \mathrm{x}_{3}$ & $-1,77 \times 10^{3}$ & 1 & $1,734 \times 10^{5}$ & 1,0210 & 0,3314 \\
$\mathrm{x}_{1} \mathrm{x}_{4}$ & 16,61 & 1 & 1516,35 & 1,0960 & 0,2989 \\
$\mathrm{x}_{2} \mathrm{x}_{3}$ & $-3,42 \times 10^{3}$ & 1 & $1,737 \times 10^{5}$ & 1,9690 & 0,0772 \\
$\mathrm{x}_{2} \mathrm{X}_{4}$ & $-326,96$ & 1 & 16311,00 & 2,0050 & 0,0728 \\
$\mathrm{x}_{3} \mathrm{x}_{4}$ & $-2,10 \times 10^{3}$ & 1 & $1,728 \times 10^{5}$ & 1,2130 & 0,2530 \\
\hline
\end{tabular}

* Para os coeficientes lineares a ANOVA mostrou conjuntamente um valor de $p<$ 0,0001 baseado no valor de f, com G.L. 4 e 10.

$\mathrm{O}$ valor de $\mathrm{p}$ foi estimado por meio do valor $\mathrm{t}$ com o numero de G.L. do erro residual. 
TABELA E 2.1 - ANOVA da regressão para o modelo quadrático da regressão de módulo elástico para o sistema PVP/glicerol/ágar.

\begin{tabular}{|c|c|c|c|c|c|}
\hline $\begin{array}{l}\text { Fonte de } \\
\text { variação }\end{array}$ & $\begin{array}{c}\text { Soma } \\
\text { quadrática }\end{array}$ & $\begin{array}{l}\text { Grau de } \\
\text { liberdade }\end{array}$ & $\begin{array}{c}\text { Média } \\
\text { quadrática }\end{array}$ & razão F & valor $p$ \\
\hline Modelo & 96702,17 & 9 & 10744,69 & 44,34 & $<0,0001$ \\
\hline Mistura linear & 71256,47 & 3 & 23752,16 & 98,02 & $<0,0001$ \\
\hline$x_{1} x_{2}$ & 7717,96 & 1 & 7717,96 & 31,85 & 0,0003 \\
\hline$x_{1} x_{3}$ & 799,48 & 1 & 799,48 & 3,30 & 0,1027 \\
\hline$x_{1} x_{4}$ & 984,50 & 1 & 984,50 & 4,06 & 0,0746 \\
\hline$x_{2} x_{3}$ & 54,05 & 1 & 54,05 & 0,22 & 0,6480 \\
\hline$x_{2} x_{4}$ & 6485,98 & 1 & 6485,98 & 26,77 & 0,0006 \\
\hline$x_{3} x_{4}$ & 528,13 & 1 & 528,13 & 2,18 & 0,1740 \\
\hline Resíduo & 2180,84 & 9 & 242,32 & & \\
\hline Falta de ajuste & 1988,37 & 8 & 248,55 & 1,29 & 0,5955 * \\
\hline Erro puro & 192,47 & 1 & 192,47 & & \\
\hline Total corrigido & 98883,01 & 18 & & & \\
\hline
\end{tabular}

TABELA E 2.2 - Coeficientes reais, em percentual, estimados para a regressão de módulo elástico para o sistema PVP/glicerol/ágar.

\begin{tabular}{lrrrrc}
\hline Variável & $\begin{array}{c}\text { Coeficiente } \\
\text { Real }\end{array}$ & $\begin{array}{c}\text { Grau de } \\
\text { liberdade }\end{array}$ & erro padrão & valor $\mathrm{v}$ & valor $\mathrm{p}$ \\
\hline $\mathrm{X}_{1}$ & $-19,07$ & 1 & 45,21 & 42,1860 & \\
$\mathrm{X}_{2}$ & 800,51 & 1 & 963,87 & 83,0517 & $*$ \\
$\mathrm{x}_{3}$ & $-2,29 \times 10^{3}$ & 1 & 11100,72 & 20,6563 & \\
$\mathrm{X}_{4}$ & $-0,33$ & 1 & 16,75 & 1,9946 & \\
$\mathrm{X}_{1} \mathrm{x}_{2}$ & $-916,77$ & 1 & 1175,45 & 77,9931 & 0,0003 \\
$\mathrm{X}_{1} \mathrm{x}_{3}$ & $2,97 \times 10^{3}$ & 1 & 11827,21 & 25,1031 & 0,1027 \\
$\mathrm{X}_{1} \mathrm{X}_{4}$ & 26,66 & 1 & 95,70 & 27,8571 & 0,0746 \\
$\mathrm{X}_{2} \mathrm{X}_{3}$ & $-768,10$ & 1 & 11768,21 & 6,5269 & 0,6480 \\
$\mathrm{X}_{2} \mathrm{X}_{4}$ & $-818,99$ & 1 & 1145,48 & 71,4976 & 0,0006 \\
$\mathrm{X}_{3} \mathrm{X}_{4}$ & $2,40 \times 10^{3}$ & 1 & 11760,74 & 20,3984 & 0,1740 \\
\hline
\end{tabular}

* Para os coeficientes lineares a ANOVA mostrou conjuntamente um valor de $p<$ 0,0001 baseado no valor de f, com G.L. 4 e 10.

$\mathrm{O}$ valor de $\mathrm{p}$ foi estimado por meio do valor $\mathrm{t}$ com o numero de G.L. do erro residual. 
TABELA E 3.1 - ANOVA da regressão para o modelo quadrático da regressão de módulo elástico para o sistema PVA/KC/ágar.

\begin{tabular}{lrrrrr}
\hline $\begin{array}{l}\text { Fonte de } \\
\text { variação }\end{array}$ & $\begin{array}{c}\text { Soma } \\
\text { quadrática }\end{array}$ & $\begin{array}{c}\text { Grau de } \\
\text { liberdade }\end{array}$ & $\begin{array}{c}\text { Média } \\
\text { quadrática }\end{array}$ & razão $F$ & valor $p$ \\
\hline Modelo & 2119,48 & 9 & 235,50 & 73,64 & $<0,0001$ \\
Mistura linear & 801,51 & 3 & 267,17 & 83,54 & $<0,0001$ \\
$\mathrm{x}_{1} \mathrm{x}_{2}$ & 272,84 & 1 & 272,84 & 85,31 & $<0,0001$ \\
$\mathrm{x}_{1} \mathrm{x}_{3}$ & 217,20 & 1 & 217,20 & 67,92 & $<0,0001$ \\
$\mathrm{x}_{1} \mathrm{x}_{4}$ & 396,70 & 1 & 396,70 & 124,04 & $<0,0001$ \\
$\mathrm{X}_{2} \mathrm{x}_{3}$ & 21,02 & 1 & 21,02 & 6,57 & 0,0334 \\
$\mathrm{X}_{2} \mathrm{X}_{4}$ & 300,55 & 1 & 300,55 & 93,98 & $<0,0001$ \\
$\mathrm{x}_{3} \mathrm{x}_{4}$ & 218,56 & 1 & 218,56 & 68,34 & $<0,0001$ \\
Resíduo & 25,58 & 8 & 3,20 & & \\
Total corrigido & 2145,06 & 17 & & & \\
\hline
\end{tabular}

Erro do modelo $= \pm 1,79 \% \quad R^{2}$ aj. $=0,9747$

TABELA E 3.2 - Coeficientes reais, em percentual, estimados para a regressão de módulo elástico para o sistema PVA/KC/ágar.

\begin{tabular}{lrrrrc}
\hline Variável & $\begin{array}{c}\text { Coeficiente } \\
\text { Real }\end{array}$ & $\begin{array}{c}\text { Grau de } \\
\text { liberdade }\end{array}$ & erro padrão & valor $t$ & valor $\mathrm{p}$ \\
\hline $\mathrm{x}_{1}$ & 33,53 & 1 & 2,44 & 1374,0697 & \\
$\mathrm{x}_{2}$ & $4,15 \times 10^{3}$ & 1 & 726,34 & 570,8071 & $*$ \\
$\mathrm{x}_{3}$ & $-3,70 \times 10^{3}$ & 1 & 753,59 & 490,8505 & \\
$\mathrm{x}_{4}$ & 0,72 & 1 & 2,09 & 34,2392 & \\
$\mathrm{x}_{1} \mathrm{x}_{2}$ & $-4,04 \times 10^{3}$ & 1 & 786,17 & 513,6294 & $<0,0001$ \\
$\mathrm{x}_{1} \mathrm{x}_{3}$ & $3,76 \times 10^{3}$ & 1 & 820,59 & 458,3288 & $<0,0001$ \\
$\mathrm{x}_{1} \mathrm{x}_{4}$ & $-42,48$ & 1 & 6,86 & 619,2041 & $<0,0001$ \\
$\mathrm{x}_{2} \mathrm{x}_{3}$ & $1,53 \times 10^{3}$ & 1 & 1074,31 & 142,6032 & 0,0334 \\
$\mathrm{x}_{2} \mathrm{X}_{4}$ & $-4,22 \times 10^{3}$ & 1 & 782,07 & 539,0822 & $<0,0001$ \\
$\mathrm{x}_{3} \mathrm{X}_{4}$ & $3,73 \times 10^{3}$ & 1 & 812,27 & 459,6994 & $<0,0001$ \\
\hline
\end{tabular}

* Para os coeficientes lineares a ANOVA mostrou conjuntamente um valor de $p<$ 0,0001 baseado no valor de f, com G.L. 4 e 10.

$\mathrm{O}$ valor de $\mathrm{p}$ foi estimado por meio do valor $\mathrm{t}$ com o numero de G.L. do erro residual. 


\section{APÊNDICE F - Análise estatística - Resistência à perfuração}

TABELA F 1.1 - ANOVA da regressão para o modelo linear da regressão de força puntiforme para o sistema PVP/PEG/ágar.

\begin{tabular}{lccccc}
\hline $\begin{array}{l}\text { Fonte de } \\
\text { variação }\end{array}$ & $\begin{array}{c}\text { Soma } \\
\text { quadrática }\end{array}$ & $\begin{array}{c}\text { Grau de } \\
\text { liberdade }\end{array}$ & $\begin{array}{c}\text { Média } \\
\text { quadrática }\end{array}$ & razão F & valor $\mathrm{p}$ \\
\hline Modelo & 14,40 & 3 & 4,80 & 101,74 & $<0,0001$ \\
Mistura linear & 14,40 & 3 & 4,80 & 101,74 & $<0,0001$ \\
Resíduo & 0,57 & 12 & 0,047 & & \\
Total corrigido & 14,97 & 15 & & & \\
\hline
\end{tabular}

Erro do modelo $= \pm 0,22 \mathrm{~N} \quad R^{2}$ aj. $=0,9527$

TABELA F 1.2 - Coeficientes reais, em percentual, estimados para a regressão de força puntiforme para o sistema PVP/PEG/ágar.

\begin{tabular}{crrrrl}
\hline Variável & $\begin{array}{c}\text { Coeficiente } \\
\text { Real }\end{array}$ & $\begin{array}{c}\text { Grau de } \\
\text { liberdade }\end{array}$ & erro padrão & valor $\mathrm{t}$ & valor $\mathrm{p}$ \\
\hline $\mathrm{x}_{1}$ & $-0,07$ & 1 & 0,89 & 7,5056 & \\
$\mathrm{x}_{2}$ & 0,05 & 1 & 2,81 & 1,7260 & $*$ \\
$\mathrm{x}_{3}$ & $-1,49$ & 1 & 8,55 & 17,3673 & \\
$\mathrm{x}_{4}$ & 0,01 & 1 & 0,19 & 2,6316 & \\
\hline
\end{tabular}

* Para os coeficientes lineares a ANOVA mostrou conjuntamente um valor de $p<$ 0,0001 baseado no valor de f, com G.L. 4 .

$\mathrm{O}$ valor de $\mathrm{p}$ foi estimado por meio do valor $\mathrm{t}$ com o numero de G.L. do erro residual. 
TABELA F 2.1 - ANOVA da regressão para o modelo quadrático da regressão de força puntiforme para o sistema PVP/glicerol/ágar.

\begin{tabular}{|c|c|c|c|c|c|}
\hline $\begin{array}{l}\text { Fonte de } \\
\text { variação }\end{array}$ & $\begin{array}{c}\text { Soma } \\
\text { quadrática }\end{array}$ & $\begin{array}{l}\text { Grau de } \\
\text { liberdade }\end{array}$ & $\begin{array}{c}\text { Média } \\
\text { quadrática }\end{array}$ & razão F & valor $p$ \\
\hline Modelo & 42,28 & 9 & 4,70 & 52,33 & $<0,0001$ \\
\hline Mistura linear & 36,47 & 3 & 12,16 & 135,47 & $<0,0001$ \\
\hline$x_{1} x_{2}$ & 0,48 & 1 & 0,48 & 5,36 & 0,0432 \\
\hline$x_{1} x_{3}$ & 0,57 & 1 & 0,57 & 6,33 & 0,0306 \\
\hline$x_{1} x_{4}$ & 0,36 & 1 & 0,36 & 3,96 & 0,0746 \\
\hline$x_{2} x_{3}$ & 0,18 & 1 & 0,18 & 2,00 & 0,1876 \\
\hline$x_{2} x_{4}$ & 0,48 & 1 & 0,48 & 5,34 & 0,0435 \\
\hline$x_{3} x_{4}$ & 0,41 & 1 & 0,41 & 4,61 & 0,0573 \\
\hline Resíduo & 0,90 & 10 & 0,090 & & \\
\hline Falta de ajuste & 0,89 & 9 & 0,099 & 25,44 & 0,1527 \\
\hline Erro puro & $3,901 \times 10^{3}$ & 1 & $3,901 \times 10^{3}$ & & \\
\hline Total corrigido & 43,16 & 19 & & & \\
\hline
\end{tabular}

TABELA F 2.2 - Coeficientes reais, em percentual, estimados para a regressão de força puntiforme para o sistema PVP/glicerol/ágar.

\begin{tabular}{crrrrr}
\hline Variável & $\begin{array}{c}\text { Coeficiente } \\
\text { Real }\end{array}$ & $\begin{array}{c}\text { Grau de } \\
\text { liberdade }\end{array}$ & $\begin{array}{r}\text { erro } \\
\text { padrão }\end{array}$ & valor $t$ & valor $\mathrm{p}$ \\
\hline $\mathrm{x}_{1}$ & 0,35 & 1 & 0,87 & 39,9770 & \\
$\mathrm{x}_{2}$ & $-6,62$ & 1 & 17,94 & $-36,8774$ & $*$ \\
$\mathrm{x}_{3}$ & 65,84 & 1 & 213,59 & 30,8232 & \\
$\mathrm{x}_{4}$ & 0,01 & 1 & 0,32 & 1,5938 & \\
$\mathrm{x}_{1} \mathrm{x}_{2}$ & 6,95 & 1 & 21,74 & 31,9798 & 0,0432 \\
$\mathrm{x}_{1} \mathrm{x}_{3}$ & $-79,16$ & 1 & 227,59 & $-34,7830$ & 0,0306 \\
$\mathrm{x}_{1} \mathrm{x}_{4}$ & $-0,51$ & 1 & 1,84 & $-27,5163$ & 0,0746 \\
$\mathrm{x}_{2} \mathrm{x}_{3}$ & $-44,05$ & 1 & 225,38 & $-19,5448$ & 0,1876 \\
$\mathrm{x}_{2} \mathrm{X}_{4}$ & 6,86 & 1 & 21,47 & 31,9395 & 0,0435 \\
$\mathrm{x}_{3} \mathrm{X}_{4}$ & $-67,16$ & 1 & 226,30 & $-29,6761$ & 0,0573 \\
\hline
\end{tabular}

* Para os coeficientes lineares a ANOVA mostrou conjuntamente um valor de $p<$ 0,0001 baseado no valor de f, com G.L. 4 e 10.

$\mathrm{O}$ valor de $\mathrm{p}$ foi estimado por meio do valor $\mathrm{t}$ com o numero de G.L. do erro residual. 
TABELA F 3.1 - ANOVA da regressão para o modelo linear da regressão de força puntiforme para o sistema PVA/KC/ágar.

\begin{tabular}{lccccc}
\hline $\begin{array}{l}\text { Fonte de } \\
\text { variação }\end{array}$ & $\begin{array}{c}\text { Soma } \\
\text { quadrática }\end{array}$ & $\begin{array}{c}\text { Grau de } \\
\text { liberdade }\end{array}$ & $\begin{array}{c}\text { Média } \\
\text { quadrática }\end{array}$ & razão F & valor $p$ \\
\hline Modelo & 48,40 & 3 & 16,13 & 26,41 & $<0,0001$ \\
Mistura linear & 48,40 & 3 & 16,13 & 26,41 & $<0,0001$ \\
Resíduo & 7,33 & 12 & 0,61 & & \\
Total corrigido & 55,73 & 15 & & & \\
\hline
\end{tabular}

Erro do modelo $= \pm 0,78 \% \quad R^{2}$ aj. $=0,8356$

TABELA F 3.2 - Coeficientes reais, em percentual, estimados para a regressão de força puntiforme para o sistema PVA/KC/ágar.

\begin{tabular}{cccccc}
\hline Variável & $\begin{array}{c}\text { Coeficiente } \\
\text { Real }\end{array}$ & $\begin{array}{c}\text { Grau de } \\
\text { liberdade }\end{array}$ & erro padrão & valor t & valor $\mathrm{p}$ \\
\hline $\mathrm{x}_{1}$ & $-0,24$ & 1 & 0,57 & 42,5965 & \\
$\mathrm{x}_{2}$ & $-3,27$ & 1 & 6,72 & 48,6027 & $*$ \\
$\mathrm{x}_{3}$ & $-0,96$ & 1 & 6,04 & 15,9735 & \\
$\mathrm{x}_{4}$ & 0,01 & 1 & 0,53 & 2,5472 & \\
\hline
\end{tabular}

* Para os coeficientes lineares a ANOVA mostrou conjuntamente um valor de $p<$ 0,0001 baseado no valor de f, com G.L. 4.

$\mathrm{O}$ valor de $\mathrm{p}$ foi estimado por meio do valor $\mathrm{t}$ com o numero de G.L. do erro residual. 


\section{APÊNDICE G - Análise estatística - Deformação na perfuração}

TABELA G 1.1 - ANOVA da regressão para o modelo quadrático da regressão de deformação na perfuração para o sistema PVP/PEG/ágar.

\begin{tabular}{lccccr}
\hline \multicolumn{1}{c}{$\begin{array}{c}\text { Fonte de } \\
\text { variação }\end{array}$} & $\begin{array}{c}\text { Soma } \\
\text { quadrática }\end{array}$ & $\begin{array}{c}\text { Grau de } \\
\text { liberdade }\end{array}$ & $\begin{array}{c}\text { Média } \\
\text { quadrática }\end{array}$ & razão $\mathrm{F}$ & valor $\mathrm{p}$ \\
\hline Modelo & 2288,31 & 9 & 254,26 & 31,88 & 0,0002 \\
Mixtura linear & 1732,49 & 3 & 577,50 & 72,41 & $<0,0001$ \\
$\mathrm{x}_{1} \mathrm{x}_{2}$ & 3,88 & 1 & 3,88 & 0,49 & 0,5118 \\
$\mathrm{x}_{1} \mathrm{x}_{3}$ & 74,23 & 1 & 74,23 & 9,31 & 0,0225 \\
$\mathrm{X}_{1} \mathrm{x}_{4}$ & $7.214 \times 10^{-3}$ & 1 & $7,214 \times 10^{-3}$ & $9,046 \times 10^{-4}$ & 0,9770 \\
$\mathrm{X}_{2} \mathrm{X}_{3}$ & 105,45 & 1 & 105,45 & 13,22 & 0,0109 \\
$\mathrm{X}_{2} \mathrm{X}_{4}$ & 5,51 & 1 & 5,51 & 0,69 & 0,4376 \\
$\mathrm{X}_{3} \mathrm{X}_{4}$ & 84,97 & 1 & 84,97 & 10,65 & 0,0172 \\
Resíduo & 47,85 & 6 & 7,98 & & \\
Total corrigido & 2336,17 & 15 & & & \\
\hline
\end{tabular}

Erro do modelo $= \pm 2,82 \% \quad R^{2}$ aj. $=0,9488$

TABELA G 1.2 - Coeficientes reais, em percentual, estimados para a regressão de deformação na perfuração para o sistema PVP/PEG/ágar.

\begin{tabular}{lrrrrr}
\hline Variável & $\begin{array}{c}\text { Coeficiente } \\
\text { Real }\end{array}$ & $\begin{array}{c}\text { Grau de } \\
\text { liberdade }\end{array}$ & erro padrão & valor t & valor $\mathrm{p}$ \\
\hline $\mathrm{x}_{1}$ & $-3,12$ & 1 & 363,23 & 0,8596 & \\
$\mathrm{x}_{2}$ & 46,02 & 1 & 5840,25 & 0,7879 & $*$ \\
$\mathrm{x}_{3}$ & $1,63 \times 10^{3}$ & 1 & 50662,24 & 3,2194 & \\
$\mathrm{X}_{4}$ & 0,27 & 1 & 12,31 & 2,2153 & \\
$\mathrm{X}_{1} \mathrm{x}_{2}$ & $-41,86$ & 1 & 6004,98 & 0,6971 & 0,0907 \\
$\mathrm{X}_{1} \mathrm{x}_{3}$ & $-1,56 \times 10^{3}$ & 1 & 51220,71 & 3,0515 & 0,4110 \\
$\mathrm{X}_{1} \mathrm{X}_{4}$ & 0,15 & 1 & 506,01 & 0,0301 & 0,0047 \\
$\mathrm{X}_{2} \mathrm{X}_{3}$ & $-1,70 \times 10^{3}$ & 1 & 46759,00 & 3,6357 & 0,1157 \\
$\mathrm{X}_{2} \mathrm{X}_{4}$ & $-50,76$ & 1 & 6104,77 & 0,8314 & 0,0383 \\
$\mathrm{X}_{3} \mathrm{X}_{4}$ & $-1,69 \times 10^{3}$ & 1 & 51651,66 & 3,2642 & 0,3326 \\
\hline
\end{tabular}

* Para os coeficientes lineares a ANOVA mostrou conjuntamente um valor de $p=$ 0,0002 baseado no valor de f, com G.L. 4 e 10.

$\mathrm{O}$ valor de $\mathrm{p}$ foi estimado por meio do valor $\mathrm{t}$ com o numero de G.L. do erro residual. 
TABELA G 2.1 - ANOVA da regressão para o modelo quadrático da regressão de deformação na perfuração para o sistema PVP/glicerol/ágar.

\begin{tabular}{|c|c|c|c|c|c|}
\hline $\begin{array}{l}\text { Fonte de } \\
\text { variação }\end{array}$ & $\begin{array}{c}\text { Soma } \\
\text { quadrática }\end{array}$ & $\begin{array}{l}\text { Grau de } \\
\text { liberdade }\end{array}$ & $\begin{array}{c}\text { Média } \\
\text { quadrática }\end{array}$ & razão F & valor $p$ \\
\hline Modelo & 6153,76 & 9 & 683,75 & 20,86 & 0,0051 \\
\hline Mixtura linear & 5564,23 & 3 & 1854,74 & 56,60 & 0,0010 \\
\hline$x_{1} x_{2}$ & 361,26 & 1 & 361,26 & 11,02 & 0,0294 \\
\hline$x_{1} x_{3}$ & 159,05 & 1 & 159,05 & 4,85 & 0,0923 \\
\hline$x_{1} x_{4}$ & 187,93 & 1 & 187,93 & 5,73 & 0,0748 \\
\hline$x_{2} x_{3}$ & 156,64 & 1 & 156,643 & 4,78 & 0,0941 \\
\hline$x_{2} x_{4}$ & 382,09 & 1 & 382,09 & 11,66 & 0,0269 \\
\hline$x_{3} x_{4}$ & 177,39 & 1 & 177,39 & 5,41 & 0,0806 \\
\hline Resíduo & 131,08 & 4 & 32,77 & & \\
\hline Total corrigido & 6284,84 & 13 & & & \\
\hline
\end{tabular}

Erro do modelo $= \pm 5,73 \% \quad R^{2}$ aj. $=0,9322$

TABELA G 2.2 - Coeficientes reais, em percentual, estimados para a regressão de deformação na perfuração para o sistema PVP/glicerol/ágar.

\begin{tabular}{lrrrrc}
\hline Variável & $\begin{array}{c}\text { Coeficiente } \\
\text { Real }\end{array}$ & $\begin{array}{c}\text { Grau de } \\
\text { liberdade }\end{array}$ & erro padrão & valor $\mathrm{l}$ & valor $\mathrm{p}$ \\
\hline $\mathrm{x}_{1}$ & $-14,56$ & 1 & 24,07 & 60,5081 & \\
$\mathrm{x}_{2}$ & 260,06 & 1 & 482,69 & 53,8771 & $*$ \\
$\mathrm{x}_{3}$ & $-1,81 \times 10^{3}$ & 1 & 5427,46 & 33,4226 & \\
$\mathrm{x}_{4}$ & $-0,52$ & 1 & 11,82 & 4,3655 & \\
$\mathrm{x}_{1} \mathrm{x}_{2}$ & $-274,68$ & 1 & 598,64 & 45,8840 & 0,0294 \\
$\mathrm{x}_{1} \mathrm{x}_{3}$ & $1,76 \times 10^{3}$ & 1 & 5785,54 & 30,4380 & 0,0923 \\
$\mathrm{x}_{1} \mathrm{x}_{4}$ & 18,90 & 1 & 57,11 & 33,0918 & 0,0748 \\
$\mathrm{x}_{2} \mathrm{x}_{3}$ & $1,68 \times 10^{3}$ & 1 & 5569,47 & 30,2183 & 0,0941 \\
$\mathrm{x}_{2} \mathrm{X}_{4}$ & $-279,97$ & 1 & 593,30 & 47,1885 & 0,0269 \\
$\mathrm{x}_{3} \mathrm{x}_{4}$ & $1,86 \times 10^{3}$ & 1 & 5788,67 & 32,1490 & 0,0806 \\
\hline
\end{tabular}

* Para os coeficientes lineares a ANOVA mostrou conjuntamente um valor de $p=$ 0,0051 baseado no valor de f, com G.L. 4 e 10.

$\mathrm{O}$ valor de $\mathrm{p}$ foi estimado por meio do valor $\mathrm{t}$ com o numero de G.L. do erro residual. 
TABELA G 3.1 - ANOVA da regressão para o modelo cúbico especial da regressão de deformação na perfuração para o sistema PVA/KC/ágar.

\begin{tabular}{|c|c|c|c|c|c|}
\hline $\begin{array}{l}\text { Fonte de } \\
\text { variação }\end{array}$ & $\begin{array}{c}\text { Soma } \\
\text { quadrática }\end{array}$ & $\begin{array}{l}\text { Grau de } \\
\text { liberdade }\end{array}$ & $\begin{array}{c}\text { Média } \\
\text { quadrática }\end{array}$ & razão F & valor $p$ \\
\hline Modelo & $1,547 \times 10^{5}$ & 13 & 11898,19 & 1158,93 & $<0,0001$ \\
\hline Mistura linear & 96273,42 & 3 & 32091,14 & 3125,81 & $<0,0001$ \\
\hline $\mathrm{x}_{1} \mathrm{x}_{2}$ & 4435,40 & 1 & 4435,40 & 432,03 & 0,0002 \\
\hline $\mathrm{x}_{1} \mathrm{x}_{3}$ & 5116,41 & 1 & 5116,41 & 498,36 & 0,0002 \\
\hline $\mathrm{x}_{1} \mathrm{X}_{4}$ & 2469,07 & 1 & 2469,07 & 240,50 & 0,0006 \\
\hline$x_{2} x_{3}$ & 5056,85 & 1 & 5056,85 & 492,56 & 0,0002 \\
\hline$x_{2} x_{4}$ & 4494,60 & 1 & 4494,60 & 437,79 & 0,0002 \\
\hline$x_{3} x_{4}$ & 5085,63 & 1 & 5085,63 & 495,36 & 0,0002 \\
\hline$x_{1} x_{2} x_{3}$ & 5006,81 & 1 & 5006,81 & 487,68 & 0,0002 \\
\hline $\mathrm{x}_{1} \mathrm{X}_{2} \mathrm{X}_{4}$ & 241,45 & 1 & 241,45 & 23,52 & 0,0167 \\
\hline$x_{1} x_{3} x_{4}$ & 89,11 & 1 & 89,11 & 8,68 & 0,0602 \\
\hline $\mathrm{X}_{2} \mathrm{X}_{3} \mathrm{X}_{4}$ & 5266,43 & 1 & 5266,43 & 512,97 & 0,0002 \\
\hline Resíduo & 30,80 & 3 & 10,27 & & \\
\hline Total corrigido & $1,547 \times 10^{5}$ & 16 & & & \\
\hline
\end{tabular}

Erro do modelo $= \pm 3,20 \%$

$R^{2} a j .=0,9989$

TABELA G 3.2 - Coeficientes reais, em percentual, estimados para a regressão de deformação na perfuração para o sistema PVA/KC/ágar.

\begin{tabular}{|c|c|c|c|c|c|}
\hline Variável & $\begin{array}{c}\text { Coeficiente } \\
\text { Real }\end{array}$ & $\begin{array}{l}\text { Grau de } \\
\text { liberdade }\end{array}$ & erro padrão & valor $t$ & valor $p$ \\
\hline $\mathrm{x}_{1}$ & 323,76 & 1 & 9,58 & 3379,4896 & \\
\hline$x_{2}$ & $6,84 \times 10^{4}$ & 1 & 5602,55 & 1220,8726 & * \\
\hline$x_{3}$ & $3,28 \times 10^{4}$ & 1 & 2581,45 & 1270,2164 & \\
\hline $\mathrm{x}_{4}$ & 5,49 & 1 & 14,45 & 38,0138 & \\
\hline$x_{1} x_{2}$ & $-9,69 \times 10^{4}$ & 1 & 5983,19 & 1620,0388 & 0,0002 \\
\hline$x_{1} x_{3}$ & $-2,28 \times 10^{4}$ & 1 & 2726,63 & 836,9306 & 0,0002 \\
\hline $\mathrm{x}_{1} \mathrm{x}_{4}$ & $-422,06$ & 1 & 48,94 & 862,4058 & 0,0006 \\
\hline$x_{2} x_{3}$ & $-8,47 \times 10^{6}$ & 1 & 85682,94 & 9886,4488 & 0,0002 \\
\hline $\mathrm{x}_{2} \mathrm{X}_{4}$ & $-6,95 \times 10^{4}$ & 1 & 5856,32 & 1186,7521 & 0,0002 \\
\hline$x_{3} x_{4}$ & $-3,33 \times 10^{4}$ & 1 & 2733,56 & 1217,8258 & 0,0002 \\
\hline$x_{1} x_{2} x_{3}$ & $8,68 \times 10^{6}$ & 1 & 94826,94 & 9157,7351 & 0,0002 \\
\hline$x_{1} x_{2} x_{4}$ & $3,37 \times 10^{4}$ & 1 & 1673,19 & 2011,1284 & 0,0167 \\
\hline$x_{1} x_{3} x_{4}$ & $-1,34 \times 10^{4}$ & 1 & 1093,36 & 1221,9214 & 0,0602 \\
\hline $\mathrm{x}_{2} \mathrm{X}_{3} \mathrm{X}_{4}$ & $8,56 \times 10^{6}$ & 1 & 91102,75 & 9391,5936 & 0,0002 \\
\hline
\end{tabular}

* Para os coeficientes lineares a ANOVA mostrou conjuntamente um valor de $p<$ 0,0001 baseado no valor de f, com G.L. 4 e 14.

$\mathrm{O}$ valor de $\mathrm{p}$ foi estimado por meio do valor $\mathrm{t}$ com o numero de G.L. do erro residual. 


\section{REFERÊNCIAS BIBLIOGRÁFICAS}

1.ABAD, L.V.; RELLEVE, L.S.; ARANILLA, C.T., ROSA, A.M.D. Properties of radiation synthesized PVP-kappa carrageenan hydrogel blends, Radiat. Phys. Chem., v. 68, p. 901-908, 2003

2. AJJI, Z,; OTHAMAN, i,; ROSIAK, J, M, Production of hydrogels wound dressings using gamma radiation, Nucl. Instr. Meth. Phys. Res. B: Beam Interactions with Materials and Atoms, v. 229,n. 3-4, pp.375-380, 2005.

3.AJJI, Z; MIRJALILIB, G.; ALKHATABA, A.; DADA, H. Use of electron beam for the production of hydrogel dressings. Rad. Phys. Chem., v. 77, p. 200202, 2008.

4.ALCÂNTARA, M.T.S.; BRANT,,A.J.C.; GIANNINI, D.R.; PESSOA,J.O.C.P.; ANDRADE, A.B.; . RIELLA, H.G.; LUGÃO, A.B. Influence of dissolution processing of PVA blends on the characteristics of their hydrogels synthesized by radiation-Part I: Gelfraction, swelling, and mechanical properties. Rad. Phys. Chem., v. 81, p. 1465-1470, 2012.

5.ALISTAIR, M. (Ed.) STEPHEN,GLYN O. PHILLIPS, PETER A. WILLIAMS. Food Polysaccharides and Their Applications.. CRC Press. USA, $2^{a}$. Ed. 2006

6.ALISTE, A. J.; VIEIRA, F. F.; MASTRO, N.L.D. Radiation efects on agar, Alginates and carrageenan to be used as food additives. Rad. Phys. Chem. , v. 57, p. $305-308,2000$.

7. AMARAL, R.H. Estudo da incorporação e liberação de um extrato de algas vermelhas em membranas de hidrogel. 2009. Dissertação (mestrado). Instituto de Pesquisas Energéticas e Nucleares, São Paulo.

8. Agência Nacional de Vigilância Sanitária. Teste de Suscetibilidade aos Antimicrobianos. ATMracional, 2008. Disponivel em

9. <http://www.anvisa.gov.br/servicosaude/controle/rede $\mathrm{rm} / \mathrm{cursos} / \mathrm{atm}$ racion al/modulo2/metodos5.htm >. Acessado em 29.11.2012

10. AQUINO, K. A. S. Sterilization by Gamma Irradiation, Gamma Radiation, Prof. Feriz Adrovic (Ed.), 2012. InTech, Disponível em: $<$ http://www.intechopen.com/books/gammaradiation/sterilization-by-gammairradiation >. Acesso em 23 jan. 2013.

11. ASTM D882-95: Standard test method for tensile properties of thin plastic sheeting. American Society for testing and materials, 1995.

12. ASTM D 570: Test Method of Test Water Absorption of Plastics, American Society for testing and materials, 1998 
13. BELONI, J. Nucleation, growth and properties of nanoclusters studied by radiation chemistry Application to catalysis. Catalysis Today, v. 113, p.141156, 2006.

14. BENAMER, S.; MAHLOUS, M.; BOUKRIF, A.; MANSOURI, B.; YOUCEF S.L. Synthesis and characterization of hydrogels based on poly(vinyl pyrrolidone), Nucl. Instr. and Meth. Phys. Res., B, v. 248, p. 284-290, 2006.

15. BLANES, L. Tratamento de feridas. Baptista-Silva JCC. Cirurgia vascular: guia ilustrado. São Paulo: 2004. Disponível em: <http://www.bapbaptista.com > Acesso em 28 nov.2012.

16. BOESE, K.U. Collargol, seine Anwendung und seine Erfolgein der Chirurgie und Gynakologie. Dtsch. Z. Chir., v.163, p. 1-2, 1921 in: Bernd Nowack, Harald F. Krug, Murray Height. 120 Years of Nanosilver History: Implications for Policy Makers. Environ. Sci. Technol., v. 45, p. 1177-1183, 2011.

17.BUDAVARI, S.; O’NEIL, M.J.; SMITH, A.; HECKELMAN,P.E.; KINNEARY, J.F. The Merck Index: An Encyclopedia of Chemicals and Drugs, 19. ed., p.1741, 1996.

18. CARTER, MJ; TINGLEY, K.; WARRINER, R.A. Silver treatments and silverimpregnated dressings for the healing of leg wounds and ulcers: $A$ systematic review and meta-analysis. J. Am. Acad. Dermatol., v. 63, p. 668-79, 2010.

19. CARVALHO, R.A.; GROSSO, C.R.F. Efeito do tratamento térmico e enzimático nas propriedades de filmes de gelatina. Ciênc. Tecnol. Aliment. v. 26, n.3, 495-501, 2006.

20. CHAPIRO, A, Radiation chemistry of polymeric systems, New York, NY. John Wiley \& San, 1962.

21. CHARLESBY, A.; ALEXANDER, P. Reticulation of polymers in aqueous solution by y-rays. J. Chim. Phys. Phys-Chim. Biol., v. 52, p.699-709, 1955 in CHAPIRO A. and LEGRIS, C. Gel formation in the radiolysis of poly(N-vinylpyrrolidone) solutions. Radiat. Phys. Chem., v. 28, n. 2, p. 143144, 1986.

22. CIAPETTI, G., GRANCHI, D., VERRI, E.; SAVARINO, L,; CAVEDAGNA, D.; PIZZPFERRATO, A.. Application of a combination of neutral red and amido black staining for rapid, reliable cytotoxicity testing of biomaterials.

Biomaterials, v. 17, p. 1259-64, 1996.

23. DENG, M.; SHALABY, W. Polymers as Biomaterials. Performance of plastics, Witold Brostow. (Ed.),Hanser/Garner Pulications, Inc. Munich, 2001. 
24. DORATI, R.; COLONA, C.; TOMASI, C.; GENTA, I.; MODENA, T.; FAUCITANO, A.; BUTTAFAVA, A.; CONTli, B.; $\gamma$-irradiation of PEGd,IPLA and PEG-PLGA Multiblock Copolymers: II. Effect of Oxygen and EPR Investigation. AAPS Pharm. Sci.Tech. v. 9 n.4, p. 1110-1118, 2008.

25. DRURY, J.L.; MOONEY, D.J. Hydrogels for tissue engineering: scaffold design variables and applications. Biomaterials, v. 24, p. 4337-4351, 2003.

26. ESCOBAR, J. L.; GARCIA, D.M.; ZALDIVAN, D.; KATIME, I. Hidrogeles, Principales características en el diseño de sistemas de liberación controlada de fármacos. Ver. Iberoam. Pol., v.3, n. 3, p. 1-25, 2002.

27. FARHATAZIZ; RODGERS, M.A.J. Radiation chemistry: Principles and applications. New York, N,Y.: VCH Publishers Inc., 1987.

28. FIELD, C.K.; KERSTEIN, M.D. Overview of wound healing in a moist environment. Am. J. Surg., v.167,1A, p. S2-S6,1994.

29. FINTER, N. B.. Dye Uptake Methods for Assessing Viral Cytopathogenicity and their Application to Interferon Assays. J. gen. Virol., v. 5), 5, 419-427, 1969.

30. FOLTTMANN, $\mathrm{H}$. and QUADIR, A. Polyvinylpyrrolidone (PVP) - One of the Most Widely Used Excipients in Pharmaceuticals: An Overview. Drug Delivery Technology. v. 8, n.6, 2008.

31. GANJI, F.; VASHEGHANI-FARAHANI, S.; VASHEGHANI-FARAHANI, E.Theoretical Description of Hydrogel Swelling: A Review. Iranian Pol. J., v.19, n. 5, p. 375-398, 2010.

32. GEMEINHART, RA; Park, H.; Park, K. Pore structure of superporous hydrogels, Polym. Adv. Technol, v.11, p. 617-625, 2000.

33. GLICKSMAN, M. Seaweed extracts. Gum Technology in the food Industry. New York, N. Y.: Academic, p. 199-273, 1969.

34. GONTARD, N.; GUILBERT, S.; CUQ, J. -L. Water and glycerol as plasticizer affect mechanical and water vapor barrier properties of an edible wheat gluten film. J. Food Sci., v. 58, p. 206-211, 1993.

35. GOPAL, N. G. S. Radiation sterilization of pharmaceuticals and polymers. Radiat. Phys. Chem., v. 12, p. 35-50, 1978.

36. GRAHAM, N.B. Poly(ethylene oxide) and related hydrogels, in: PEPPAS, N.A. (Ed.), Hydrogels in Medicine and Pharmacy. v. 2, CRC Press, Boca Raton, FL, p. 95-113, 1987.

37. GUEVEN, O. An overview of current development in applied radiation chemistry of polymers in Advances in radiation chemistry of polymers. IAEA, VIENNA, 2004. (IAEA-TECDOC-1420). 
38. GULREZ, S., AI-ASSAF, S. and PHILLIPS, G.O. Hydrogels: Methods of preparation, characterisation and applications in molecular and environmental bioengineering In Carpi, A. (ed), Analysis and Modeling to Technology Applications, cap. 5, p. 117-150, 2011.

39. GUPTA, P.; VERMANI, K,; GARG, S. Hydrogels: from controlled release to pH-responsive drug delivery. DDT, v. 7, n.10, 2002.

40. GURNY, R.; DOELKER, E.; Peppas, N.A. Modelling of sustained release of water soluble drugs from porous, hydrophobic polymers, Biomaterials, v. 3, 27-32, 1982.

41. GUYOTARD, S.; GOURY, V.; DARBORD, J.C. Effects of ionizing radiation on bacterial endotoxins: comparison between gamma radiations and accelerated electrons. Rad. Phys. Chem., v. 31, n.4-6, p. 679-684, 1988.

42. HANSEN, M. B.; NIELSEN, S. E.; Berg, K. Re-examination and further development of a precise and rapid dye method for measuring cell growth/cell kill. Journal of Immunological Methods., v. 119, p.203-10, 1989.

43. HENGLEIN, A. Physicochemical Properties of Small Metal Particles in Solution: "Microelectrode" Reactions, Chemisorption, Composite Metal Particles, and the Atom-to-Metal Transition. J. Phys. Chem., v. 97, p. 5475471, 1993.

44. HENNINK, W.E.; NOSTRUM, V.C.F. Novel crosslinking methods to design hydrogels. Advanced Drug Delivery Reviews, v. 54 p. 13-36, 2002.

45. HILL, D.J.T.; WHITTAKER, S.K. Radiation chemistry of polymers in Encyclopedia of Polymer Sceince and Technology. John Wiley \& Sons, Inc., 2005.

46. HILMY, N., DARWIS, D., AND HARDININGSIH, L, Poly(N-vinyl pyrrolidone) hydrogel: Hydrogel composition as wound dressing for tropical environment, Radiat. Phys. Chem. v. 42, n. 4-6, 911-914, 1993.

47. HINDS, K.D.; KIM, S.W. Effects of PEG conjugation on insulin properties. Advanced Drug Delivery Reviews. v. 54, p. 505-530, 2002.

48. HOFFMAN, A.S. Hydrogels for biomedical applications. Adv. Drug Deliv. Rev., v. 43, p. 3-12, 2002.

49. HOFFMAN, A.S. Hydrogels for biomedical applications. Adv. Drug Deliv. Rev., v. 64, p. 18-23, 2012.

50. HOLLINGER, M. A. Toxicological aspects of topical silver pharmaceuticals. Crit. Rev. Toxc., v.2, 255-60, 1996. 
51. HUANG, T.; XU, H.; JIAO, K.; ZHU,L.; BROWN, H.R.; WANG, H. A Novel Hydrogel with High Mechanical Strength:A Macromolecular Microsphere Composite Hydrogel. Adv. Mater., v.19, p. 1622-1626, 2007.

52. International consensus. Appropriate use of silver dressings in wounds. AN EXPERT WORKING GROUP CONSENSUS. London: Wounds International, 2012. Disponível em:<www.woundsinternational.com>. Acesso em 10 mar. 2013.

53. ISO document 10993-1, 1992. Biological evaluation of medical devices, Part 1, Guidance on selection of tests.

54. ISO document 10993-5. Biological compatibility of medical devices - Part 5. Tests for cytotoxicity: in vitro methods. 1992.

55.JOVANOVIC', Ž.; KRKLJEš, A.; STOJKOVSKA, J.; TOMIC', S.; OBRADOVIC', B.; MiSKOVISC'-STANKIVIC' ,V.; KACAREVIC-POPVIC, Z. Synthesis and characterization of silver/poly(N-vinyl-2-pyrrolidone) hydrogel nanocomposite obtained by in situ radiolytic method. Radiat. Phys. Chem. v. 80,1208-1215, 2011.

56. JOVANOVIC', Ž.; RADOSAVLJEVIC', A.; SILJEGOVIC', M.; BIBIC', N.; MISKOVIC'-STANKIVIC', V.; KACAREVIC-POPOVIC, Z.; Structural and optical characteristics of silver/poly(N-vinyl-2-pyrrolidone) nanosystems synthesized by $\boldsymbol{\gamma}$-irradiation. Radiat. Phys. Chem. v. 81, n. 11, p. 17201728, 2012.

57. KOPEČEK, J. Hydrogels from soft contact lenses and implants to selfassembled nanomaterials. Polym. Sci. A. Polym. Chem., v. 47, n. 22; p. 5929-5946, 2009.

58. KRKLJES, A.; NEDELJKOVIC, J.M.; KACAREVIC-POPOVIC, Z.M. Fabrication of Ag-PVA hydrogel nanocompósito by $\gamma$-irradiation, Polymer Bulletin, v.58, 271-279, 2007a.

59. KRKLJĚS, A. N.; MARINOVIC-CÍNCOVIC', M. T.; KACAREVIC-POPOVIC, Z. M.; NEDELJKOVIC J.M. Radiolytic synthesis and characterization of AgPVA nanocomposites. European Polymer Journal, v. 43,p. 2171-2176, 2007b.

60. KUDELA, V. Hydrogels, In: Encyclopedia of Polymer Science and Engineering, 7 ed, Wiley, New York, p, 783-807, 1987.

61. KUMAR, M.; VARSHNEY, L.; FRANCISB, S. Radiolytic formation of Ag clusters in aqueous polyvinyl alcohol solution and hydrogel matrix. Radiat. Phys. Chem. v. 73, p, 21-27, 2005.

62. Lesões com curativos de hidrogel. (C) Ferida de dificil cicatrização. Disponível em: <http://kikgel.com.pl/?p=114>. Acesso em 30 set. 2012. 
63. LIMOLI, C.L.; KAPLAN, M.I.; GIEDZINSKI, E.; MORGAN, W.F. Attenuation of radiation-induced genomic instability by free radical scavengers and cellular proliferation Free Rad. I Biol. Med, v. 31, n. 1, 10-19, 2001.

64. LINCOPAN, N.; MAMIZUKUKA, E.M.; CARMONA-RIBEIRO, A.M. Low nephrotoxicity of an effective amphotericin $B$ formulation with cationic bilayer fragments. J. Antimicr. Chemoth, v. 55,p. 727-734, 2005.

65. LOPÉRGOLO, L.C. Estudo da estrutura e dos parâmetros de reticulação de membranas hidrofílicas à base de poly(N-vinilpirrolidona) induzidas por radiação. 2002a Tese (doutorado). Instituto de Pesquisas Energéticas e Nucleares. São Paulo.

66. LOPÉRGOLO, L. C.; LUGÃO, A. B.; CATALANI, L. H. Development of a poly( $N$-vinyl-2-pyrrolidone)/poly(ethylene glycol) hydrogel membrane reinforced with methyl methacrylate-grafted polypropylene fibers for possible use as wound dressing. J. Appl. Pol. Sc., v. 86, p. 662-666, $2002 b$.

67. LOPÉRGOLO, L.C.; CATALANI, L.H.; MACHADO, L.D.B.; RELA, P.R.; LUGÃO, A.B.. Development of reinforced hydrogels $Đ$ I. Radiation induced graft copolymerization of methylmethacrylate on non-woven polypropylene fabric. Rad. Phys. Chem., v. 57,, p.451-454, 2000.

68. LOPES, C. M.A.; FELISBERTI, M.I. Mechanical behaviour and biocompatibility of poly(1-vinyl-2-pyrrolidinone)-gelatin IPN hydrogels. Biomaterials, v. 24 p. 1279-1284, 2003.

69. LO S.F; HAYTER. M.; CHANG, C.J, HU, W.Y,; LEE, L.L. A systematic review of silver-releasing dressings in the management of infected chronic wounds. J. Clin. Nurs., v. 17; 1973-1985, 2008.

70.LO, S.F.; CHANG, C.J.; HU, W.Y.; HAYTER, M.; CHANG, Y.T. The effectiveness of silver-releasing dressings in the management of nonhealing chronic wounds: a meta-analysis. J. Clin. Nurs., v. 18: 716-728, 2009.

71. LOWMAN, A.M.; DZIUBLA, T,; BURES, P,; PEPPAS, Structural and dynamic response of neutral and intelligent networks in biomedical environments, Adv. Chem. Eng.: Molec. Cell. Found. Biomat., v. 29, p.75130, 2004.

72. LUGÃO, A.B.; MACHADO, L.D.B.; MIRANDA, L.F.; ALVAREZ, M.R.; ROSIAK, J.M. Study of wound dressing structure and hydration/dehydration properties, Radiat. Phys. Chem., v. 52. n.1-6, 319-322, 1998.

73. LUGÃO, A.B.; MALMONGE, S.M. Use of radiation in the production of hydrogels. Nucl. Instrum. Meth. Phys. Res., v.185, B, p. 37-42, 2001. 
74. MACHADO, A.C.H.R., Desenvolvimento e avaliação da incorporação e liberação de óleo de açaí em hidrogéis de poli(N-vinil-2-pirrolidona). 2010, Instituto de Pesquisas Energéticas e Nucleares. São Paulo.

75. MARAMBIO-JONES, C.; HOEK, E. M.V. A review of the antibacterial effects of silver nanomaterials and potential implications for human health and the environment. J. Nanopart. Res. v.12, p.1531-1551, 2010.

76. MERRILL, E.W.; DENNISON, K.A.; SUNG, C. Partitioning and diffusion of solutes in hydrogels of poly(ethylene oxide). Biomat., v.14, n.15, 11171126, 1993.

77. MICHAELS, J.A; CAMPBELL, B.; KING, B. et al. Randomized controlled trial and cost effectiveness analysis of silver-donating antimicrobial dressings for venous leg ulcers (VULCAN trial). Br. J. Surg., v. 96, n. 10, p.1147-56, 2009.

78. MIRANDA, L.F. Estudo de parâmetros de processo para a síntese de membranas hidrofílicas à base de poli(N-vinil-2-pirrolidona). 1999. Tese (doutorado). Instituto de Pesquisas Energéticas e Nucleares, São Paulo.

79. MIE, G. Ann. Phys. 1908, 25, 377 in: HENGLEIN, A.. Physicochemical properties of small metal Pprticles in solution: "Microelectrode" reactions, chemisorption, Ccmposite metal particles, and the atom-to-metal transition. J. Phys. Chem. v.97, p. 547-5471, 1993.

80. Ministério da saúde, 2012. Relatório de gestão 2011, Disponível em: $<$ http://portal.saude.gov.br/portal/arquivos/pdf/SAS Relatorio de Gestao 2 011.pdf >. Acesso em 07 jan. 2013.

81. MOCK, J. J.; BARBIC, M.; SMITH, D.R.; SCHULTZ, D.A.; SCHULTZ. Shape effects in plasmon resonance of individual colloidal silver Nanoparticles. $\boldsymbol{J}$. Chem. Phys., v. 116, p. 6755, 2002.

82. MOMESSO, R.G.R.A.P. Incorporação e liberação de resveratrol em hidrogéis poliméricos. 2010a. Dissertação (mestrado), Instittuto de Pesquisas Energéticas e Nucleares. São Paulo.

83. MOMESSO, R.G.R.A.P; Moreno, C.S.; Rogero, S.O.; Rogero, J.R.; Spencer, P.; Lugão. A.B. Radiation stability of resveratrol in immobilization on poly vinyl pyrrolidone hydrogel dressing for dermatological use. Rad. Phys.Chem., v.79, p. 283-285, 2010b.

84. MONTEIRO, D.R.; GORUP, L.F.; TAKAMIYA, A.S.; RUVOLLO-FILHO, A.C.; CAMARGO, E.R.; BARBOSA, D.B. The growing importance of materials that prevent microbial adhesion: antimicrobial effect of medical devices containing silver. Intern. J. Antimicr. Agents, v. 34, p.103-110, 2009. 
85. MORONES, J.R.; ELECHIGUERRA, J.L.; CAMACHO, A.; HOLT, K.; KOURI, J.B.; RAMIREZ, J.T.; YACAMAN, M.J. The bactericidal effect of silver Nanoparticles. Nanotechnology, v.16, p. 2346-2353, 2005.

86. NAIR, L.S.; LAURENCIN, C.T. Silver nanoparticles: Synthesis and therapeutic applications. J. Biomed. Nanotech., v. 3, 301-316, 2007.

87. NEVES, P.R.; MAMIZUKA, E.M.; LEVY, C.E.; LINCOPAN, N. Pseudomonas aeruginosa multirresistente: um problema endêmico no Brasil. J. Bras.

Patol. Med. Lab., v. 47, n. 4, p. 409-420, 2011.

88. NG, W. M. Nanocrystalline silver and burn. ANZ J. Surg., v.78, n.1, 2008.

89. NIELSEN, L. E., LANDEL R. F., Mechanical Properties of Polymers and Composites, New York, Marcel Dekker, 2a ed., 1994.

90. NIJENHUIS, K.T.E. Thermoreversible networks. Viscoelastic properties and structure of gels. Advances in Polymer Science. cap.3, v. 130, p.37, 1997, Ed. Springer.

91. NOWACK, B.; KRUG, H. F.; HEIGHT, M. 120 Years of Nanosilver History: Implications for Policy Makers. Environ. Sci. Technol., v. 45, p. 1177-1183, 2011.

92. OLIVEIRA, M.J.A.; AMATO, V. S.; PARRA, D. F.; LUGÃO, A.B. Glucantime drug delivery comparation between crosslinked membranes irradiation versus esterification. In: INTERNATIONAL NUCLEAR ATLANTIC CONFERENCE - INAC, 2009, Rio de Janeiro, RJ, Brazil, 27 setembro - 2 outubro, 2009.

93. OMIDIAN, H.; PARK, K. Swelling agents and devices in oral drug delivery. J. Drug del. Sci Tech., v.18, n. 2, p. 83-93, 2008.

94.PAGLIARO M.; ROSSI M. Future of Glycerol, Chap.1 Glycerol: Properties and production. $2^{\text {nd }}$ edition, 2010 Disponível em:

http://www.rsc.org/ebooks/archive/free/BK9781849730464/BK97818497304 64-00001.pdf, acessado em 21/04/2010.

95.PAL, S.; TAK, Y.K.; SONG, J.M. Does the antibacterial activity of silver nanoparticles depend on the shape of the nanoparticle? A study of the gram-negative bacterium Escherichia coli. Applied and Envirom. Microb. , p. 1712-1720, 2007.

96. PARRA, D.F.; TADINI, C.C.; PONCE, P.; LUGÃO, A.B. Mechanical properties and water vapor transmission in some blends of cassava starch edible films. Carbohydrate Polymers, v. 58, p. 475-481, 2004.

97. PATEL, A.; MEQUANINT, K. Hydrogel Biomaterials. In: Biomedical Engineering - Frontiers and Challenges, Fazel-Rezai, R. (Ed.), InTech, 2011, cap. 14. Disponívl em: 
$<$ http://www.intechopen.com/books/biomedical-engineering-frontiers-andchallenges/hydrogel-biomaterials>. Acesso em 28 out. 2012.

98. PAUL, D. R. Polymer blends: Phase behavior and property relationships. In Multicomponent Polymer Materials; Advances in Chemistry, v. $211 \mathrm{Am}$. Chem. Soc.: Washington, DC, D. R. Paul, L. H. Sperling (Ed), 1985.

99. PAWDE, S. M.; DESHMUKH, K. Characterization of polyvinyl alcohol/gelatin blend hidrogel films for biomedical applications. J. of Appl. Polym. Sci., v. 109, n. 5, 3431-3437, 2008.

100. PEPPAS, N.A. ; KHARE, A.K. Preparation, structure and diffusional behavior of hydrogel in controlled release. Adv. Drug Deliv. Rev., v. 11, 135, 1993.

101. PEPPAS, N.A. Hydrogels in Medicine and Pharmacy. Vol. 1 Fundamentals, Peppas Ed., CRC Press, Boca Raton, FL., 1997.

102. PEPPAS, N.A., BURES, P; LEOBANDUNG, W.; ICHIKAWA, H. Hydrogels in pharmaceutical formulations. $\square$ Eur. J. Pharm. Biopharm., v. 50, n.1, 2746, 2000.

103. PEPPAS, N.A; HILT, J. Z.; KHADEMHOSSEINI, A.; LANGER, R. Hydrogels in Biology and Medicine: From Molecular Principles to Bionanotechnology. Adv. Mater., 18, 1345-1360, 2006.

104. PHILIPP, W.H.; MARSIK, S.J. Radiation-induced reduction of divalent copper salts in solution. Nasa Technical Note. NASA TN D-4451, 1968.

105. PRASAD, K.; MEHTA, G.; MEENA, R.; SIDDHANTA, A.K. Hydrogel-forming agar-graft-PVP and k-carrageenan-graft-PVP blends: Rapid synthesis and characterization. J. Appl. Pol. Sc., v. 102, n. 4 p. 3654-3663, 2006.

106. RATNER, B. D.; HOFFMAN, A. S. Synthetic Hydrogels for Medical Applications. In Related applications in hydrogels for medical and related applications. J. Am. Chem. Society., v. 31, Cap. 1, Washington, 1976.

107. RELLEVE, L.; YOSHII F.; ROSA, A.D.; KUME, T. Radiation-modified hydrogel based on poly(N-vinyl-2-pyrrolidone) and carrageenan. Die Angewandte Makromolekulare Chemie. v. 273, n. 4718, p. 63-68, 1999.

108. RELLEVE, L.; NAGASAWA, N.; LUAN, L.Q.; YAGI, T.; ARANILLA, C.; ABAD, L.; KUME, T.; YOSHII, F.; ROSA, A. D. Degradation of carrageenan by radiation. Polymer Degradation and Stability, v. 87, p. 403-410, 2005.

109. REUVERS, P.; GREENSTOCK, C.L.; BORSA, J.; CHAPMAN, J. D. Studies on the mechanism of chemical radioprotection by Dimethyl Sulphoxide. Int. J. Radiat. Biol., v. 24, n. 5, p. 533-536, 1973. 
110. ROGERO, S.O., LUGÃO, A. B.; IKEDA, T. I.; CRUZ, Á.S. Teste in vitro de citotoxicidade: Estudo comparativo entre duas metodologias., Materials Research, v. 6, n. 3; p. 317-320, 2003.

111. ROMAN, Z.; ZOFIA, M.; NAWROTEK, K.; LEK, U. Drug release from hydrogel matrices. Ecolog. Chem. Eng., v. 17- 2, 2010.

112. ROSIAK, J. M.; RUCINSKA-REYBAS, A,; PEKALA, W. Method of manufacturing of Hydrogel Dressings, US Patent $n^{\circ} 4,8171490,1989$.

113. ROSIAK, J. M.; ULANSKI, P.; PAJEWSKI, L.A.; YOSHII, F.; MAKUUCHI, K. Radiation formation of hydrogels for biomedical purposes, Some remarks and comments, Radiat. Phys. Chem. v. 46, n. 2, 161-168, 1995.

114. ROSIAK, J. M.; ULANSKI, P. Synthesis of hydrogels by irradiation of polymers in aqueous solution. Radiat. Phys. Chem., v. 55, 139-151, 1999.

115. ROSIAK, J. M.; YOSHIli, F. Hydrogels and their medical applications. Nucl. Inst. Meth. Phys. Res., B, v. 151, n. 1-4, P. 56-64, 1999.

116. SAMBERG, M.E.; OLDENBURG, S.J.; MONTEIRO-RIVIERE, N.A. Evaluation of Silver Nanoparticle Toxicity in Skin in Vivo and Keratinocytes in Vitro. Environmental Health Perspectives, v.118, n. 3, 2010.

117. SAMBERG, M.E.; LOBOA, E.G.; OLDENBURG, S.J.; MONTEIRO-RIVIERE, N.A. Silver nanoparticles do not influence stem cell differentiation but cause minimal toxicity. Nanomedicine, v.7, n. 8, p.1197-1209, 2012.

118. SANTUCCIZ, S. G.; GOBARA, S.; SANTOS, C. R.; FONTANAY, C.; LEVIN, A. S. Infections in a burn intensive care unit: experience of seven years. $\boldsymbol{J}$. Hosp. Infect., v. 53, p. $6-13,2003$.

119. SHEIKH, N.; AKHAVAN, A.; KASSAEE, M.Z. Synthesis of antibacterial silver nanoparticles by g-irradiation. Physica, E, v. 42, p.132-135, 2009.

120.SHIN, H.S.; YANG, H.J.; KIM, S.B.; LEEB, M.S. Mechanism of growth of colloidal silver nanoparticles stabilized by polyvinyl pyrrolidone in $y$ irradiated silver nitrate solution. J. Coll. Interf. Sci., v. 274, p. 89-94, 2004.

121. SINTZELI, M. B.; MERKLIi, A.; TABATABAY, C.; GURMY, R. Influence of Irradiation Sterilization on Polymers Used as Drug Carriers-A Review. Drug Dev. Ind. Pharm., v. 23, n. 9, 857-879, 1997.

122. SLAUGHTER, B.; SHAHANA, V.; KHURSHID, S.; FISHER, O.Z.; KHADEMHOSSEINI, A. and PEPPAS, N. A. Hydrogels in regenerative medicine. Adv. Mater., v. 21, p. 3307- 3329, 2009. 
123. SLISTAN-GRIJALVA, A.; HERRERA-URBINA, R.; RIVAS-SILVA, J.F.; AVALOS-BORJA, M.; CASTILLON-BARRAZA, F.F.; POSADA-

AMARILLASs, A. Classical theoretical characterization of the surface plasmon absorption band for silver spherical nanoparticles in water and ethylene glycol. Physica E: Low-dimensional Systems and

Nanostructures, v.27, p.104-112, 2005.

124. SOBRAL, P.J.A.; MENEGALLI, F.C.; HUBINGER, M.D.; ROQUES, M.A. Mechanical, water vapor barrier and thermal properties of gelatin based edible films. Food hydrocolloids, v. 15, 423-432, 2001.

125. SPINKS, J.W.T.; WOODS, R.J. An introduction to radiation chemistry, $1^{\text {a }}$ ed, New York, NY, John Wiley \& San, 1964.

126. SPINKS, J.W.T.; WOODS,R.J. An introduction to radiation chemistry. $3^{\text {a }}$ ed. New York, NY, John Wiley \& San, 1990.

127. SURI, S.; SCHMIDT, C.E. Photopatterned collagen-hyaluronic acid interpenetrating polymer network hydrogels. Acta Biomaterialia. V. 5, p.2385-2397, 2009.

128. TADAVARTHY, S. M,; MOLLER, J. H.; AMPLA'l'Z, K.. Polyvinyl alcohol (Ivalon) - A new embolic material. The Am. J. of Roentgenology, Radium Therapy, and Nucl. Medic., v.125, n. 3, p. 609 - 616, 1975.

129. TEMGIRE, M.K.; Joshi, S.S. Optical and structural studies of silver nanoparticles. Rad. Phys.Chem., v. 71, p. 1039-1044, 2004.

130. TIAN, J.; KENNETH, K. Y.; CHI-MING HO, W.; LOK, C.; YU, W.; CHE, CHI; CHIU, J.; TAM, P.K.H. Topical Delivery of Silver Nanoparticles Promotes Wound Healing. Chem. Med. Chem.v. 2, p.129 - 136, 2007.

131. TODAR, K.. Bacterial Resistance to Antibiotics em Todar's Online Textbook of Bacteriology. [s.d.] Disponível em:

<http://textbookofbacteriology.net/resantimicrobial.html> Acesso em 03 nov. 2012

132. URBAIN, W.M., Food Irradiation. Academic, Orlando, p. 351, 1986.

133. VARSHNEY, L; MAJMUDAR A, A, A new hydrogel burn dressing, Indian Patent No BOM/731/99, 1999,

134. VARSHNEY, L. Role of natural polysaccharides in radiation formation of PVA-hydrogel wound dressing. Nucl. Instr. and Meth. in Phys. Res., B 255, 343-349, 2007.

135. VERMEULEN, H; VAN HATTEM, JM, STORM-VERSLOOT MN, UBBINK DT. Topical silver for treating infected wounds. Cochrane Database Syst. Rev., v. 24, n.1, 2007. 
136. VERONESI, R.; FOCACCIA, R. Tratado de infectologia. $3^{a}$ ed. São Paulo: Atheneu, 2006. In REMPEL, L.C.T.; TIZZOT, M.R.P.A.; VASCO, J.F.M. Incidência de infecções bacterianas em pacientes queimados sob tratamento em hospital universitário de Curitiba. Ver. Bras. Queimaduras. 10, n. 1, p. 3-9, 2011.

137. WEBER, J. and McManus, A. Infection control in burn patients. Burns, v. 30, p. A16-A24, 2004.

138. Williams, D.F., 1987. Definitions in Biomaterials. Proceedings of a Consensus Conference of the European Society For Biomaterials, England, 1986, Elsevier, New York.

139. WINTER, G.D. Formation of the scab and the rate of epithelialization of superficial wounds in the skin of the young domestic pig. Nature 1962; 193293-4 In: Blanes, L. Tratamento de feridas. Baptista-Silva JCC, editor. Cirurgia vascular: guia ilustrado. São Paulo, 2004. Disponível em: URL: <http://www.bapbaptista.com>. Acesso em 02 dez. 2012.

140. WRIGHT, J. B.; LAM, K.; BURRELL, R.E. Wound management in an era of increasing bacterial antibiotic resistance: A role for topical silver treatment. Am. J. Inf. Cont., v. 26, 6, p. 572-577, 1998.

141. YANG, X.; ZHU, Z.; LIU, Q.; CHEN, x.; MA., M. Effects of PVA, agar contents, and irradiation doses on properties of PVA/ws-chitosan/glycerol hydrogels made by g-irradiation followed by freeze-thawing. Rad. Phys. Chem., v. 77, p. 954-960,2008.

142. ZHANG, Z., ZHAO, B., HU, L. PVP protective mechanism of ultrafine silver powder synthesized by chemical reduction processes. J. Solid State Chem. v.121, p. 105-110, 1996. 